Prepared in cooperation with the

U.S. Environmental Protection Agency

\title{
Aquatic Assessment of the Ely Copper Mine Superfund Site, Vershire, Vermont
}

Scientific Investigations Report 2010-5084 
Cover photograph. The confluence of Ely Brook, flowing from the back to the front of the scene, with Schoolhouse Brook, flowing from left to right. 


\section{Aquatic Assessment of the Ely Copper Mine Superfund Site, Vershire, Vermont}

By Robert R. Seal, II, Richard G. Kiah, Nadine M. Piatak, John M. Besser, James F. Coles, Jane M. Hammarstrom, Denise M. Argue, Denise M. Levitan, Jeffrey R. Deacon, and Christopher G. Ingersoll

Prepared in cooperation with the U.S. Environmental Protection Agency

Scientific Investigations Report 2010-5084 


\title{
U.S. Department of the Interior \\ KEN SALAZAR, Secretary \\ U.S. Geological Survey \\ Marcia K. McNutt, Director
}

\section{U.S. Geological Survey, Reston, Virginia: 2010}

\author{
For more information on the USGS — the Federal source for science about the Earth, its natural and living resources, \\ natural hazards, and the environment, visit http://www.usgs.gov or call 1-888-ASK-USGS \\ For an overview of USGS information products, including maps, imagery, and publications, \\ visit http://www.usgs.gov/pubprod \\ To order this and other USGS information products, visit http://store.usgs.gov
}

\begin{abstract}
Any use of trade, product, or firm names is for descriptive purposes only and does not imply endorsement by the U.S. Government.

Although this report is in the public domain, permission must be secured from the individual copyright owners to reproduce any copyrighted materials contained within this report.
\end{abstract}

Suggested citation:

Seal, R.R., II, Kiah, R.G., Piatak, N.M., Besser, J.M., Coles, J.F., Hammarstrom, J.M., Argue, D.M., Levitan, D.M., Deacon, J.R., and Ingersoll, C.G., 2010, Aquatic assessment of the Ely Copper Mine Superfund site, Vershire, Vermont: U.S. Geological Survey Scientific Investigations Report 2010-5084, 131 p. 


\section{Acknowledgments}

Thor Smith, Ann Chalmers, and Marc Zimmerman of the U.S. Geological Survey (USGS), Linda Elliot of the Vermont Department of Environmental Conservation, and Ken Munney of the U.S. Fish and Wildlife Service assisted with the field sampling program. Monique Adams, Todor Todorov, and Michael Anthony, all of the USGS, performed many of the water analyses.

The project benefited from discussions with Ed Hathaway and Bart Hoskins of the U.S. Environmental Protection Agency (USEPA), Linda Elliot, Steven Fiske, Richard Langdon, and John Schmeltzer of the Vermont Department of Environmental Conservation, Matt Kierstead (Public Archaeology Laboratory), Jason Clere (URS Corporation), and Stan Pauwels (TechLaw, Inc.). The manuscript benefited from reviews by Larry Gough, Ed Hathaway, Bart Hoskins, Ken Munney, and Stan Pauwels. The project was funded by USEPA (Region 1) and the Mineral Resources Program of the USGS. 


\section{Contents}

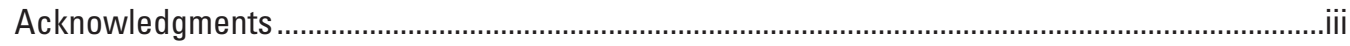

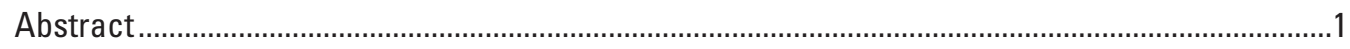

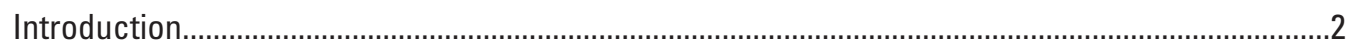

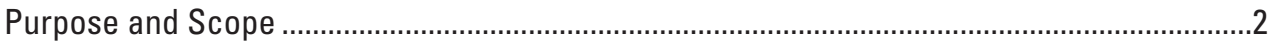

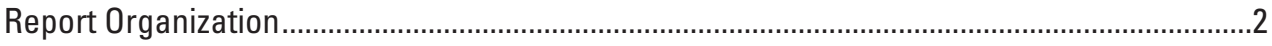

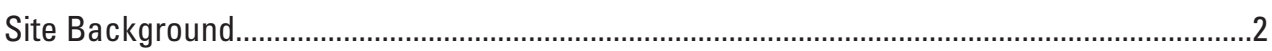

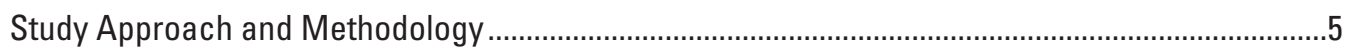

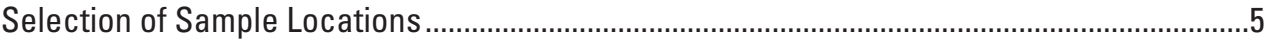

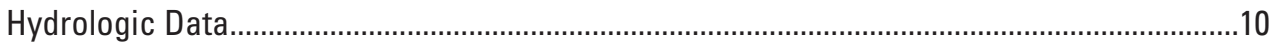

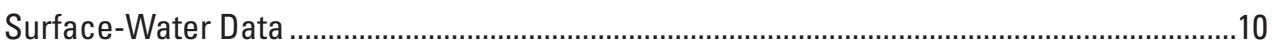

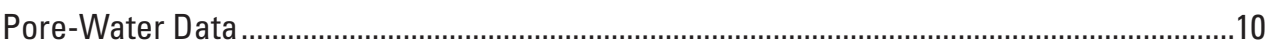

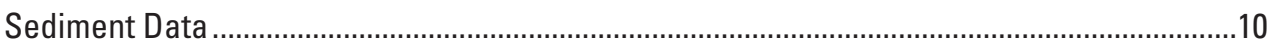

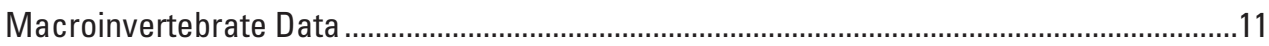

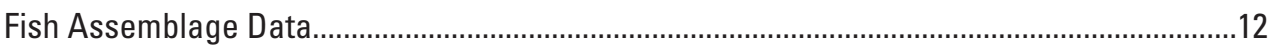

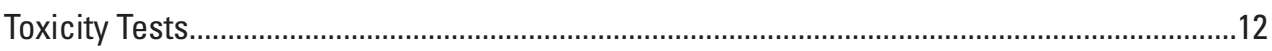

Quality-Control Procedures .......................................................................................................12

Data Analysis and Statistical Methods ................................................................................... 12

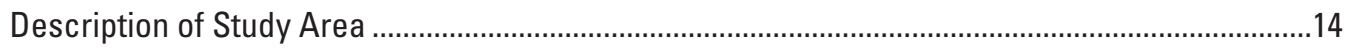

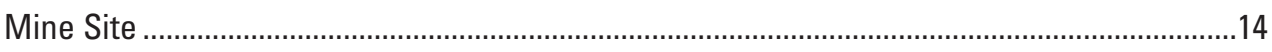

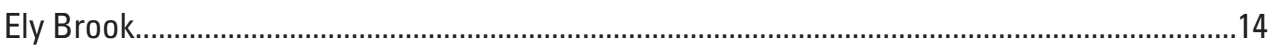

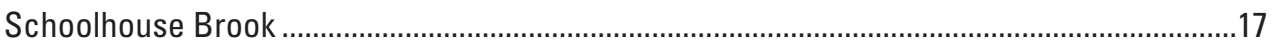

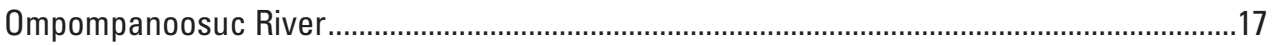

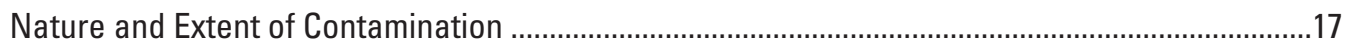

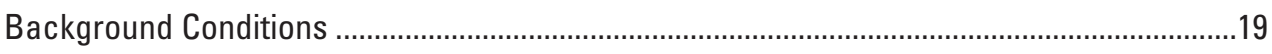

Surface-Water Geochemistry...................................................................................19

Field Parameters and Major Inorganic Constituents..............................................19

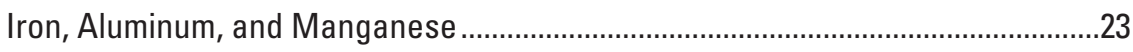

Minor and Trace Inorganic Elements ......................................................................23

Dissolved Organic Carbon and Nutrients ...............................................................23

Comparisons with Ambient Water-Quality Criteria .....................................................24

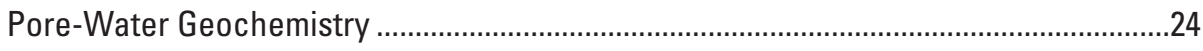

Field Parameters and Major Inorganic Constituents.................................................24

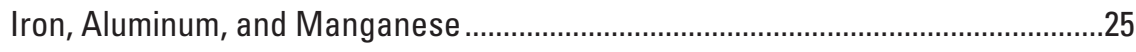

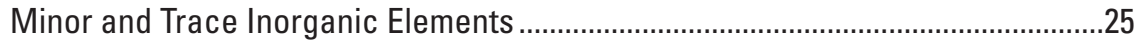

Dissolved Organic Carbon and Nutrients .................................................................25

Comparisons with Ambient Water-Quality Criteria ...................................................26

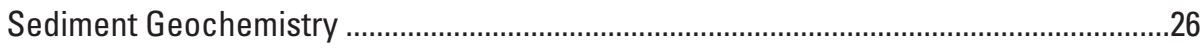

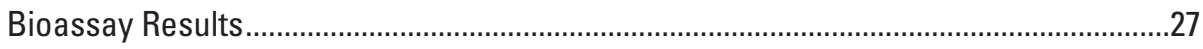

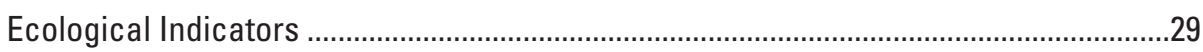




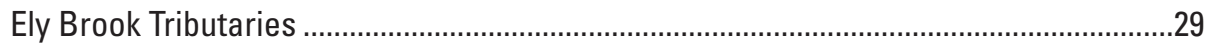

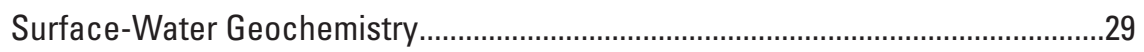

Field Parameters and Major Inorganic Constituents......................................29

Iron, Aluminum, and Manganese .................................................................32

Minor and Trace Inorganic Elements .............................................................32

Dissolved Organic Carbon and Nutrients .......................................................33

Comparisons with Ambient Water-Quality Criteria and Relations among Reaches .......................................................................................33

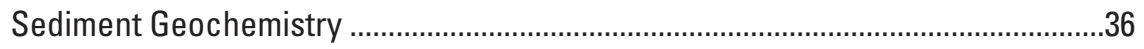

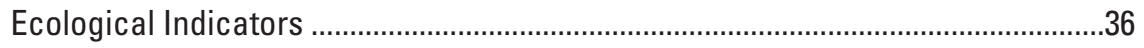

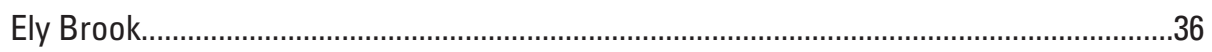

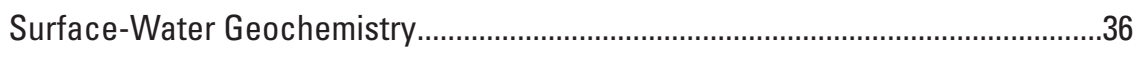

Field Parameters and Major Inorganic Constituents......................................36

Iron, Aluminum, and Manganese .................................................................

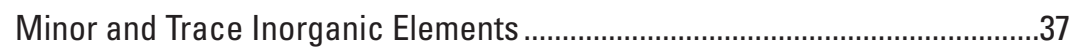

Dissolved Organic Carbon and Nutrients ....................................................37

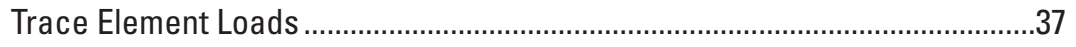

Comparisons with Ambient Water-Quality Criteria and Relations

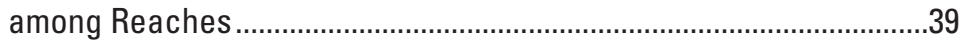

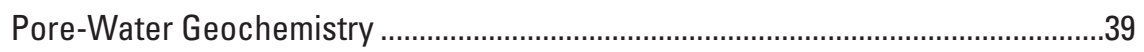

Field Parameters and Major Inorganic Constituents........................................39

Iron, Aluminum, and Manganese .....................................................................42

Minor and Trace Inorganic Elements .........................................................42

Dissolved Organic Carbon and Nutrients .....................................................42

Comparisons with Ambient Water-Quality Criteria .............................................42

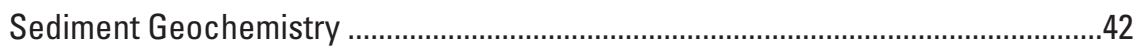

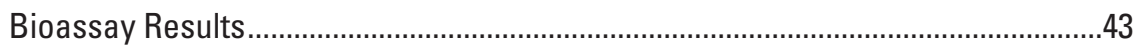

Relations among Trace Elements in Surface Water,

Pore Water, Sediment, and Aquatic Biota .....................................................43

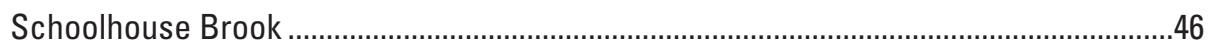

Surface-Water Geochemistry........................................................................46

Field Parameters and Major Inorganic Constituents.......................................46

Iron, Aluminum, and Manganese .................................................................46

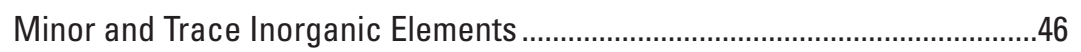

Dissolved Organic Carbon and Nutrients ......................................................46

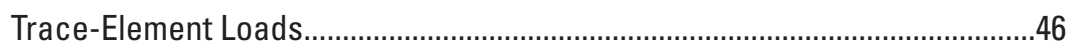

Comparisons with Ambient Water-Quality Criteria and Relations

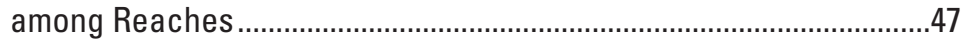

Pore-Water Geochemistry .................................................................................4

Field Parameters and Major Inorganic Constituents......................................47

Iron, Aluminum, and Manganese ..................................................................4

Minor and Trace Inorganic Elements ........................................................... 47

Dissolved Organic Carbon and Nutrients .....................................................50

Comparisons with Ambient Water-Quality Criteria ............................................50

Sediment Geochemistry ................................................................................ 50

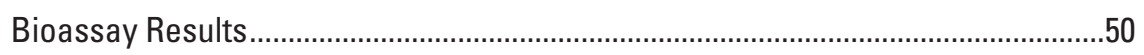


Relations among Trace Elements in Surface Water, Pore Water,

Sediment, and Aquatic Biota.........................................................................51

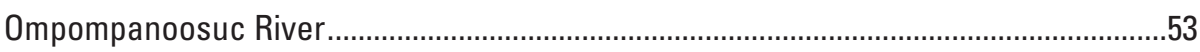

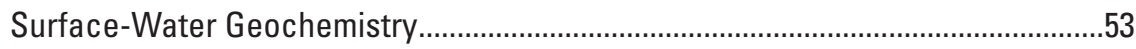

Field Parameters and Major Inorganic Constituents......................................54

Iron, Aluminum, and Manganese .................................................................54

Minor and Trace Inorganic Elements ............................................................54

Dissolved Organic Carbon and Nutrients ........................................................54

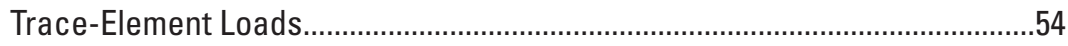

Comparisons with Ambient Water-Quality Criteria and Relations among Reaches ...............................................................................5

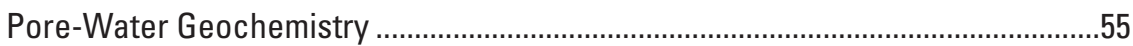

Field Parameters and Major Inorganic Constituents......................................55

Iron, Aluminum, and Manganese ..................................................................55

Minor and Trace Inorganic Elements ...........................................................55

Dissolved Organic Carbon and Nutrients ......................................................55

Comparisons with Ambient Water Quality Criteria ............................................55

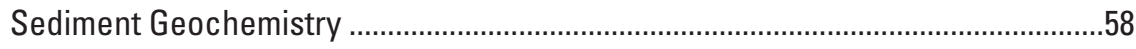

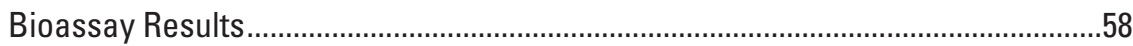

Relations among Trace Elements in Surface Water, Pore Water,

Sediment, and Aquatic Biota.......................................................................5

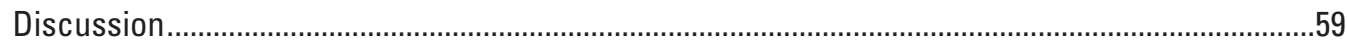

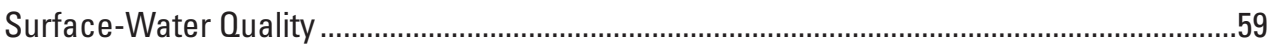

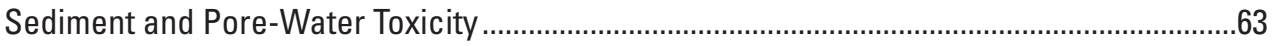

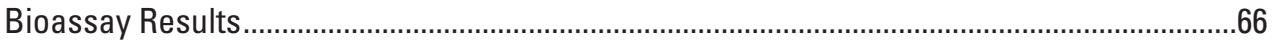

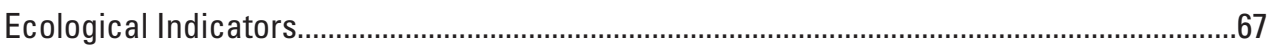

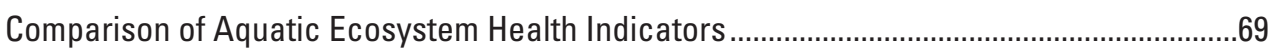

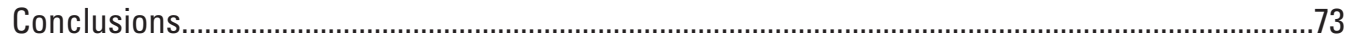

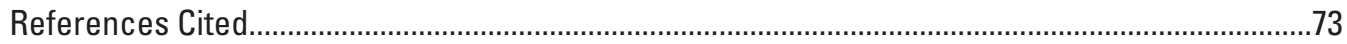

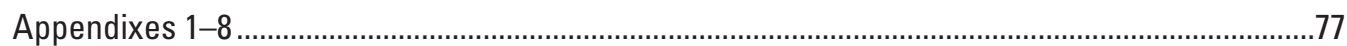




\section{Figures}

1-3. Maps showing-

1. Sampling location numbers and identifiers for data collected in the Ompompanoosuc River and Schoolhouse Brook, Vershire, VT. Also shown are the locations of the Elizabeth Mine Superfund site, and the Union Village Dam just below the confluence of the West Branch of the Ompompanoosuc River with the Ompompanoosuc River .3

2. Sampling location numbers and identifiers for data collected at the Ely Mine Superfund site, Vershire, VT...

3. The surficial geology of the Ely Mine Superfund site study area, VT

4-10. Graphs showing-

4. Flow-duration curve for U.S. Geological Survey gaging station 01141500

Ompompanoosuc River at Union Village Dam, VT, with streamflow distribution of water-quality samples collected in Ely Brook,

Schoolhouse Brook, and the Ompompanoosuc River.

5. Downstream variations in $\mathrm{pH}$ and specific conductance in surface and in situ pore waters at the Ely Mine Superfund site, Vershire, VT.

6. Downstream variations in hardness, alkalinity and sulfate concentrations in surface and in situ pore waters at the Ely Mine Superfund site, Vershire, VT .

7. Downstream variations in aluminum, iron, cadmium, copper, and zinc concentrations in surface and in situ pore waters at the Ely Mine Superfund site, Vershire, VT

8. Qualitative multi-habitat invertebrate abundance and richness values among the Ely ponds, Vershire, VT.

9. Riffle-targeted habitat invertebrate abundance and richness values in Ely Brook, abundance and richness values in Schoolhouse Brook, and abundance and richness values in the Ompompanoosuc River...

10. Depositional-targeted habitat invertebrate abundance and richness values in Ely Brook, abundance and richness values in Schoolhouse Brook, and abundance and richness values in the Ompompanoosuc River

11. Box plots showing select constituent concentrations in surface waters among four tributaries to Ely Brook at the Ely Mine Superfund site, Vershire, VT

12. Graphs showing qualitative multi-habitat invertebrate abundance and richness values relative to the gradient in hazard index values derived from trace metal concentration in surface-waters from the Ely ponds, Vershire, VT

13. Graphs showing instantaneous aluminum, iron, and manganese, and cadmium, cobalt, copper, and zinc loads at the Ely Mine Superfund site, Vershire, VT .38

14. Box plots showing select constituent concentrations in surface waters among four reaches in Ely Brook at the Ely Mine Superfund site, Vershire, VT 
15. Graphs showing riffle-targeted habitat invertebrate abundance and richness values in Ely Brook, abundance and richness values in Schoolhouse Brook, and abundance and richness values in the Ompompanoosuc River relative to the gradient in hazard index values derived from trace metal concentration in surface waters, Vershire, VT

16. Graphs showing depositional-targeted habitat invertebrate abundance and richness values in Ely Brook, abundance and richness values in Schoolhouse Brook, and abundance and richness values in the Ompompanoosuc River relative to the gradient in hazard index values derived from trace metal concentration in pore waters, Vershire, VT

17. Box plots showing select constituent concentrations in surface waters among three reaches in Schoolhouse Brook at the Ely Mine Superfund site, Vershire, VT

18-20. Graphs showing-

18. Fish assemblage index of biotic integrity scores for Schoolhouse Brook and the Ompompanoosuc River.

19. Fish assemblage index of biotic integrity compared to the hazard index for surface waters

20. Concentrations of copper and zinc in brook trout and blacknose dace tissue compared to the critical body residue values for salmonids

21. Box plots showing select constituent concentrations in surface waters among three reaches in the Ompompanoosuc River at the Ely Mine Superfund site, Vershire, VT

22-27. Graphs showing-

22. Downstream variations in aluminum, iron, cadmium, copper, and zinc hazard quotients in surface waters at the Ely Mine Superfund site, Vershire, VT. A, Ely ponds and Ely Brook; $B$, Schoolhouse Brook and the Ompompanoosuc River..

23. Downstream variations in hardness-based and Biotic Ligand Model-based hazard quotients for copper in surface waters at the Ely Mine Superfund site, Vershire, VT

24. Chronic copper water-quality criteria for surface water based on hardness and the Biotic Ligand Model with the number of riffle-targeted habitat taxa.

25. Three indices of metal toxicity risks for instream sediments from the Ely Mine site, August 2006.

26. Copper and iron concentrations in stream sediments ................................................66

27. Comparison of sediment-quality criteria with various measures of sediment toxicity. 


\section{Tables}

1. Select characteristics for sampling locations at the Ely Mine study area, Vershire, VT...

2. Select basin and reach characteristics for sampling locations at the Ely Mine study area, Vershire, VT...

3. Spearman rho values from correlating metal concentrations measured in surface water, in situ pore water, and sediment against invertebrate richness ( $\mathrm{RTH}, \mathrm{OMH}$, and DTH samples) and against the index of biotic integrity scores for the fish surveys

4. Constituents in filtered surface waters collected in August and September 2006 from the Ely Mine study area, Vershire, VT.

5. Constituents in filtered pore waters collected in August and September 2006 from the Ely Mine study area, Vershire, VT.

6. Select chemistry results for sediments collected in August and September 2006 from the Ely Mine study area, Vershire, VT.

7. Acid volatile sulfide (AVS) and simultaneously extractable metals results for stream sediments from the Ely Mine study area, Vershire, VT

8. Results of 28-day toxicity tests with the amphipod Hyalella azteca and of 10-day toxicity tests with the midge Chironomus dilutus exposed to sediments from Ely Mine site, fall 2006.

9. Summary of selected invertebrate and fish data and the hazard index used for comparison of assemblage data to water quality at sampling locations in the Ely Mine study area, Vershire, VT..

10. Summary of the hazard quotient and hazard index for select constituents in waters and stream sediments at sampling locations in the Ely Mine study area, Vershire, VT, August 21 to 23, 2006.

11. Summary of the concentration, hazard quotient, and hazard index for select constituents in pore waters at sampling locations in the Ely Mine study area, Vershire, VT, August and September 2006

12. Summary of the aquatic-life use assessments for streams associated with the Ely Mine site

13. Summary of geochemical and biological indicators of stream health in the Ely Mine study area, Vershire, VT, June to September 2006

14. Summary of geochemical and biological indicators of pond health in the Ely Mine study area, Vershire, VT, June to September 2006

Appendix 1. Summary of test conditions for sediment toxicity tests with sediments from the Ely Mine site, September 2006, conducted in accordance with USEPA and ASTM standard methods

Appendix 2. Quality-assurance, quality-control water samples for the Ely Mine study, Vershire, VT

Appendix 3. Quality-assurance, quality-control sediment samples for the Ely Mine study, Vershire, VT

Appendix 4. Acid volatile sulfide, simultaneously extractable metals, and particle-size results for stream sediments and quality-assurance, quality-control samples for the Ely Mine study area, Vershire, VT 
Appendix 5. Summary of select constituents in surface waters relative to ambient water-quality criteria for stream reaches in the Ely Mine study area, Vershire, VT, 2000 to $2007 .$.

Appendix 6. Constituents in surface waters collected in August and September 2006 from the Ely Mine study area, Vershire, VT

Appendix 7. Constituents in pore waters collected in August and September 2006 from the Ely Mine study area, Vershire, VT

Appendix 8. Chemistry results for sediments collected in August and September 2006 from the Ely Mine study area, Vershire, VT.

\section{Conversion Factors}

\begin{tabular}{|c|c|c|}
\hline Multiply & By & To obtain \\
\hline \multicolumn{3}{|c|}{ Length } \\
\hline centimeter $(\mathrm{cm})$ & 0.3937 & inch (in.) \\
\hline millimeter $(\mathrm{mm})$ & 0.03937 & inch (in.) \\
\hline meter $(\mathrm{m})$ & 3.281 & foot $(\mathrm{ft})$ \\
\hline kilometer (km) & 0.6214 & mile (mi) \\
\hline kilometer (km) & 0.5400 & mile, nautical (nmi) \\
\hline meter $(\mathrm{m})$ & 1.094 & yard $(y d)$ \\
\hline \multicolumn{3}{|c|}{ Area } \\
\hline square meter $\left(\mathrm{m}^{2}\right)$ & 0.0002471 & acre \\
\hline hectare (ha) & 2.471 & acre \\
\hline square kilometer $\left(\mathrm{km}^{2}\right)$ & 247.1 & acre \\
\hline square centimeter $\left(\mathrm{cm}^{2}\right)$ & 0.001076 & square foot $\left(\mathrm{ft}^{2}\right)$ \\
\hline square meter $\left(\mathrm{m}^{2}\right)$ & 10.76 & square foot $\left(\mathrm{ft}^{2}\right)$ \\
\hline square centimeter $\left(\mathrm{cm}^{2}\right)$ & 0.1550 & square inch $\left(\mathrm{ft}^{2}\right)$ \\
\hline hectare (ha) & 0.003861 & square mile $\left(\mathrm{mi}^{2}\right)$ \\
\hline square kilometer $\left(\mathrm{km}^{2}\right)$ & 0.3861 & square mile $\left(\mathrm{mi}^{2}\right)$ \\
\hline \multicolumn{3}{|c|}{ Volume } \\
\hline cubic meter $\left(\mathrm{m}^{3}\right)$ & 6.290 & barrel (petroleum, 1 barrel $=42$ gal) \\
\hline liter (L) & 33.82 & ounce, fluid (fl. oz) \\
\hline liter $(\mathrm{L})$ & 2.113 & pint (pt) \\
\hline liter $(\mathrm{L})$ & 1.057 & quart (qt) \\
\hline liter (L) & 0.2642 & gallon (gal) \\
\hline cubic meter $\left(\mathrm{m}^{3}\right)$ & 264.2 & gallon (gal) \\
\hline cubic meter $\left(\mathrm{m}^{3}\right)$ & 0.0002642 & million gallons (Mgal) \\
\hline liter (L) & 61.02 & cubic inch $\left(\mathrm{in}^{3}\right)$ \\
\hline cubic meter $\left(\mathrm{m}^{3}\right)$ & 35.31 & cubic foot $\left(\mathrm{ft}^{3}\right)$ \\
\hline cubic meter $\left(\mathrm{m}^{3}\right)$ & 1.308 & cubic yard $\left(\mathrm{yd}^{3}\right)$ \\
\hline cubic meter $\left(\mathrm{m}^{3}\right)$ & 0.0008107 & acre-foot (acre-ft) \\
\hline \multicolumn{3}{|c|}{ Mass } \\
\hline gram (g) & 0.03527 & ounce, avoirdupois (oz) \\
\hline kilogram $(\mathrm{kg})$ & 2.205 & pound avoirdupois (lb) \\
\hline
\end{tabular}


Temperature in degrees Celsius $\left({ }^{\circ} \mathrm{C}\right)$ may be converted to degrees Fahrenheit $\left({ }^{\circ} \mathrm{F}\right)$ as follows:

$$
{ }^{\circ} \mathrm{F}=\left(1.8 \mathrm{x}^{\circ} \mathrm{C}\right)+32
$$

Temperature in degrees Fahrenheit $\left({ }^{\circ} \mathrm{F}\right)$ may be converted to degrees Celsius $\left({ }^{\circ} \mathrm{C}\right)$ as follows:

$$
{ }^{\circ} \mathrm{C}=\left({ }^{\circ} \mathrm{F}-32\right) / 1.8
$$

Vertical coordinate information is referenced to the North American Vertical Datum of 1927 (NAVD 27).

Horizontal coordinate information is referenced to the North American Datum of 1927 (NAD 27).

Altitude, as used in this report, refers to distance above the vertical datum.

Specific conductance is given in microsiemens per centimeter at 25 degrees Celsius $(\mu \mathrm{S} / \mathrm{cm}$ at $\left.25^{\circ} \mathrm{C}\right)$.

Concentrations of chemical constituents in water are given either in milligrams per liter ( $\mathrm{mg} / \mathrm{L}$ ) or micrograms per liter $(\mu \mathrm{g} / \mathrm{L})$.

\section{Acronyms Used in this Report}

$\begin{array}{ll}\text { AFDW } & \text { ash-free dry weight } \\ \text { ALU } & \text { aquatic-life use } \\ \text { ANOVA } & \text { analysis of variance } \\ \text { ANR } & \text { Agency of Natural Resources (Vermont) } \\ \text { AVS } & \text { acid volatile sulfide } \\ \text { ATSDR } & \text { Agency for Toxic Substances and Disease Registry } \\ \text { AWOC } & \text { ambient water-quality criteria } \\ \text { BERA } & \text { Baseline Ecological Risk Assessment } \\ \text { BLM } & \text { Biotic Ligand Model } \\ \text { CBR } & \text { critical body residue } \\ \text { CCC } & \text { criterion continuous concentration } \\ \text { CERC } & \text { Columbia Environmental Research Center (USGS) } \\ \text { CERCLA } & \text { Comprehensive Environmental Response, Compensation, and Liability Act } \\ \text { CMC } & \text { criterion maximum concentration } \\ \text { CRREL } & \text { Cold Regions Research and Engineering Laboratory } \\ & \text { (U.S. Army Corps of Engineers) } \\ \text { CVAF } & \text { cold-vapor atomic fluorescence } \\ \text { CWIBI } & \text { coldwater index of biotic integrity } \\ \text { DGPS } & \text { differential global positioning system } \\ \text { DOC } & \text { dissolved organic carbon } \\ \text { DTH } & \text { depositional-targeted habitat }\end{array}$




$\begin{array}{ll}\text { ESB } & \text { equilibrium-partitioning sediment benchmark } \\ \text { HI } & \text { hazard index } \\ \text { HO } & \text { hazard quotient } \\ \text { IBI } & \text { index of biotic integrity } \\ \text { ICP-AES } & \text { inductively coupled plasma-atomic emission spectroscopy } \\ \text { ICP-MS } & \text { inductively coupled plasma-mass spectrometry } \\ \text { MWIBI } & \text { mixed water index of biotic integrity } \\ \text { PEC } & \text { probable effects concentration } \\ \text { PEO } & \text { probable effects quotient } \\ \text { OMH } & \text { qualitative multi-habitat } \\ \text { ROS } & \text { regression on order statistics } \\ \text { RPD } & \text { relative percent difference } \\ \text { RTH } & \text { Viffle-targeted habitat } \\ \text { SEM } & \text { Simultaneously extractable metals } \\ \text { SEM-AVS } & \text { Simultaneously extractable metals-acid volatile sulfide } \\ \text { TOC } & \text { total organic carbon } \\ \text { TU } & \text { toxic units } \\ \text { USACE } & \text { U.S. Army Corps of Engineers } \\ \text { USBM } & \text { Vermont Geological Survey } \\ \text { USGS } & \text { VTAWOC }\end{array}$




\section{Element Symbols Used in this Report}

\begin{tabular}{|c|c|c|c|}
\hline $\mathrm{Ag}$ & silver & $\mathrm{Mg}$ & magnesium \\
\hline $\mathrm{Al}$ & aluminum & $\mathrm{Mn}$ & manganese \\
\hline As & arsenic & Mo & molybdenum \\
\hline B & boron & $\mathrm{Na}$ & sodium \\
\hline $\mathrm{Ba}$ & barium & $\mathrm{Nb}$ & niobium \\
\hline $\mathrm{Be}$ & beryllium & $\mathrm{Nd}$ & neodymium \\
\hline $\mathrm{Bi}$ & bismuth & $\mathrm{Ni}$ & nickel \\
\hline $\mathrm{Ca}$ & calcium & $P$ & phosphorus \\
\hline $\mathrm{Cd}$ & cadmium & $\mathrm{Pb}$ & lead \\
\hline $\mathrm{Ce}$ & cerium & $\operatorname{Pr}$ & praseodymium \\
\hline $\mathrm{Cl}$ & chlorine & $\mathrm{Rb}$ & rubidium \\
\hline Co & cobalt & $\mathrm{Sb}$ & antimony \\
\hline $\mathrm{Cr}$ & chromium & $\mathrm{Sc}$ & scandium \\
\hline Cs & cesium & $\mathrm{Se}$ & selenium \\
\hline $\mathrm{Cu}$ & copper & $\mathrm{Sm}$ & samarium \\
\hline Dy & dysprosium & $\mathrm{Sr}$ & strontium \\
\hline $\mathrm{Er}$ & erbium & $\mathrm{Ta}$ & tantalum \\
\hline $\mathrm{Eu}$ & europium & $\mathrm{Tb}$ & terbium \\
\hline $\mathrm{F}$ & fluorine & Th & thorium \\
\hline $\mathrm{Fe}$ & iron & $\mathrm{Ti}$ & titanium \\
\hline $\mathrm{Ga}$ & gallium & $\mathrm{TI}$ & thallium \\
\hline $\mathrm{Gd}$ & gadolinium & $\mathrm{Tm}$ & thulium \\
\hline $\mathrm{Ge}$ & germanium & U & uranium \\
\hline Ho & holmium & V & vanadium \\
\hline $\mathrm{Hg}$ & mercury & W & tungsten \\
\hline $\mathrm{K}$ & potassium & $Y$ & yttrium \\
\hline $\mathrm{La}$ & lanthanum & $\mathrm{Yb}$ & ytterbium \\
\hline $\mathrm{Li}$ & lithium & $\mathrm{Zn}$ & zinc \\
\hline $\mathrm{Lu}$ & lutetium & $\mathrm{Zr}$ & zirconium \\
\hline
\end{tabular}




\title{
Aquatic Assessment of the Ely Copper Mine Superfund Site, Vershire, Vermont
}

\author{
By Robert R. Seal, II, Richard G. Kiah, Nadine M. Piatak, John M. Besser, James F. Coles, Jane M. Hammarstrom, \\ Denise M. Argue, Denise M. Levitan, Jeffrey R. Deacon, and Christopher G. Ingersoll
}

\section{Abstract}

The Ely Mine, which operated from 1821 to 1905 , and its area of downstream impact constitute the Ely Copper Mine Superfund site. The site was placed on the National Priorities List in 2001. The mine comprises underground workings, foundations from historical structures, several waste-rock piles, roast beds associated with the smelting operation, and slag piles resulting from the smelting. The mine site is drained by Ely Brook, which includes several tributaries, one of which drains a series of six ponds. Ely Brook empties into Schoolhouse Brook, which flows 3.3 kilometers and joins the Ompompanoosuc River.

The aquatic ecosystem at the site was assessed using a variety of approaches that investigated surface-water quality, sediment quality, and various ecological indicators of streamecosystem health. The degradation of surface-water quality is dominated by copper with localized effects caused by iron, aluminum, cadmium, and zinc. Chronic water-quality criteria for copper are exceeded in the surface water of four of the six ponds on the Ely Brook tributary, and all of Ely Brook and Schoolhouse Brook, and of the Ompompanoosuc River downstream of the confluence with Schoolhouse Brook. Comparison of hardness-based and Biotic Ligand Model-based waterquality criteria for copper yields similar results with respect to extent of impairment. However, the Biotic Ligand Model criteria are mostly lower than the hardness-based criteria and thus suggest a greater degree of impairment, particularly in the Ely Brook watershed, where dissolved organic carbon concentrations and $\mathrm{pH}$ values are lower. Surface-water toxicity testing correlates strongly with the extent of impact. Likewise, riffle-habitat benthic invertebrate richness and abundance data support these results through the stream environment. Similarly, the index of biotic integrity for the fish community in Schoolhouse Brook and the Ompompanoosuc River document degraded habitats throughout Schoolhouse Brook from Ely Brook down to the Ompompanoosuc River.

The sediment environment shows similar extents of impairment also dominated by copper, although localized degradation due to chromium, nickel, lead, and zinc was documented on the basis of probable effects concentrations. In contrast, equilibrium-partitioning sediment benchmarks indicate no toxic effects would be expected in sediments at the reference sites, and uncertain toxic effects throughout Ely Brook and Schoolhouse Brook, except for the reference sites and site EB-600M. The results for site EB-600M indicate predicted toxic effects. Acute toxicity testing of in situ pore waters using Hyalella azteca indicates severe impacts in Ely Brook reaching 100 percent lethality at site EB-90M. Acute toxicity testing of in situ pore waters using Chironomus dilutus shows similar, but not as severe, toxicity. Neither set of in situ pore-water toxicity tests showed significant impairment in Schoolhouse Brook or the Ompompanoosuc River. Chronic sediment toxicity testing using Hyalella azteca indicated significant toxicity in Ely Brook, except at site EB-90M, and in Schoolhouse Brook. The low toxicity of EB-90M may be a reflection of the low lability of copper in that sediment as indicated by a low proportion of extractable copper (1.1 percent). Depositionaltargeted habitat invertebrate richness and abundance data support these conclusions for the entire watershed, as do the index of biotic integrity data from the fish community.

The information was used to develop an overall assessment of the impact on the aquatic system that appears to be a result of the acid rock drainage at the Ely Mine. More than 700 meters of Ely Brook, including two of the six ponds, were found to be severely impacted, on the basis of water-quality data and biological assessments. The reference location was of good quality based on the water quality and biological assessment. More than 3,125 meters of Schoolhouse Brook are also severely impacted, on the basis of water-quality data and biological assessments. The biological community begins to recover near the confluence with the Ompompanoosuc River. The evidence is less conclusive regarding the Ompompanoosuc River. The sediment data suggest that the sediments could be a source of toxicity in Ely Brook and Schoolhouse Brook. The surface-water assessment is consistent with the outcome of a surface-water toxicity testing program performed by the U.S. Environmental Protection Agency for Ely Brook and Schoolhouse Brook and a surface-water toxicity testing program and in situ amphibian testing program for the ponds. 


\section{Introduction}

This report presents an evaluation of the aquatic ecosystem associated with the Ely Copper Mine Superfund site in Vershire, Orange County, VT. The Ely Copper Mine Superfund site was placed on the U.S. Environmental Protection Agency (USEPA) National Priorities List in 2001. Results of detailed mine-waste investigations show that the mine, which operated intermittently from the early 1800 s until 1905, is contributing metals and highly acidic waters to local streams (Hammarstrom and others, 2001a, b; Kierstead, 2001; Seal and others, 2001; Piatak and others, 2003, 2004; TechLaw, Inc., 2008; URS Corporation, 2009). Contaminated surface waters and sediment are transported from the mine site by Ely Brook. Ely Brook flows approximately 0.15 kilometer $(\mathrm{km})$ from the lowermost mine-waste piles before entering Schoolhouse Brook, which then flows approximately $3.3 \mathrm{~km}$ before entering the Ompompanoosuc River (figs. 1 and 2). The area included in this report comprises the site of historical mining operations, downstream aquatic habitats, and adjacent upstream aquatic habitats selected to represent unimpacted reference conditions. Water bodies include Ely Brook, which drains most of the historical mine site, the tributaries to Ely Brook, including a series of ponds which drain into one of the tributaries, Schoolhouse Brook, which receives drainage from Ely Brook, and the Ompompanoosuc River, which is the receiving water body for Schoolhouse Brook.

\section{Purpose and Scope}

The goals of this report are to (1) characterize water and sediment quality and biological communities for water bodies in the Ely Mine study area, (2) compare and contrast surfacewater, pore-water, and sediment trace-element concentrations, (3) relate trace-element concentrations to aquatic invertebrate and fish assemblages, and (4) evaluate the toxicity of surface water, pore water, and sediment. Results from this study will contribute to an understanding of the relations among the chemical, physical, and biological components of waterways that are affected by acid-mine drainage. Information from these results will be used in the development of a remedial investigation and feasibility study plan for the site, which will meet the broad U.S. Geological Survey (USGS) goal of furnishing data needed by other Federal agencies for management and remediation of contaminated sites, and will provide valuable information for the characterization of the impact of acid-mine drainage on the ecological condition of water bodies downstream of the Ely Mine site. Ultimately, this information will be used in making decisions for remedial actions necessary to mitigate future contamination from the mine and for developing a longer term monitoring program to assess the effectiveness of remediation. This report has been prepared, in part, to support the Ely Copper Mine Aquatic Baseline Ecological Risk Assessment (BERA; TechLaw, Inc., 2008) being conducted under the regulatory framework of the Comprehensive
Environmental Response, Compensation, and Liability Act (CERCLA). These two reports will complement a source-area remedial investigation being conducted by USEPA and its contractors (URS Corporation, 2009).

Supporting streamflow and water-quality data collected in August and September 2006 are stored in the USGS National Water Information System (http://nwis.waterdata.usgs.gov/ nwis). Water-quality, stream sediment, fish-tissue, and fish and benthic macroinvertebrate assemblage data collected from 2000 to 2007 are published in Argue and others (2008).

\section{Report Organization}

The report assesses the environmental conditions of the aquatic ecosystem associated with the abandoned Ely Mine site, describes the approach and methods selected to document these conditions, describes the physical characteristics of the site, documents the nature and extent of contamination, integrates this information to form a conceptual model of the site with respect to the transport and fate of contaminants, and summarizes these results in terms of risks posed to both the aquatic ecosystem and human health.

This introductory section provides background of the site including summaries of the mining history and ownership, and previous and concurrent activities at the site. The second section describes the approach used to identify sites for detailed study, and the methods employed to investigate surface water, sediment pore water, sediment, and biota characteristics, and toxicity testing. The third section describes the physical setting of the site including the historical mining landscape, geomorphology and surface-water hydrology of the watershed, depositional sites within the streams, and biologic and ecologic features. The next section documents the nature and extent of contamination in Ely and Schoolhouse Brooks, and in the Ompompanoosuc River in surface water, pore water, and sediments in terms of water-quality parameters, concentrations of metals, other inorganic constituents, organic constituents, and contaminant loads for comparison with biologic indicators of aquatic ecosystem health. The Discussion integrates the results of the previous sections to produce an integrated model describing the transport and fate of contaminants away from source areas. Implications of the aquatic ecosystem remedial investigation to a baseline ecological assessment of the site are discussed. The last section is a brief summary of the conclusions of the study.

\section{Site Background}

The Ely Copper Mine Superfund site is located in a rural area on Beanville Road, Vershire, Orange County, VT, in the watershed of Schoolhouse Brook - a tributary of the Ompompanooosuc River; the West Branch of the Ompompanoosuc River includes the Elizabeth Mine Superfund site, south of the Ely site (fig. 1). The site encompasses approximately 730 hectares (ha), of which 110 to 140 ha were used for 


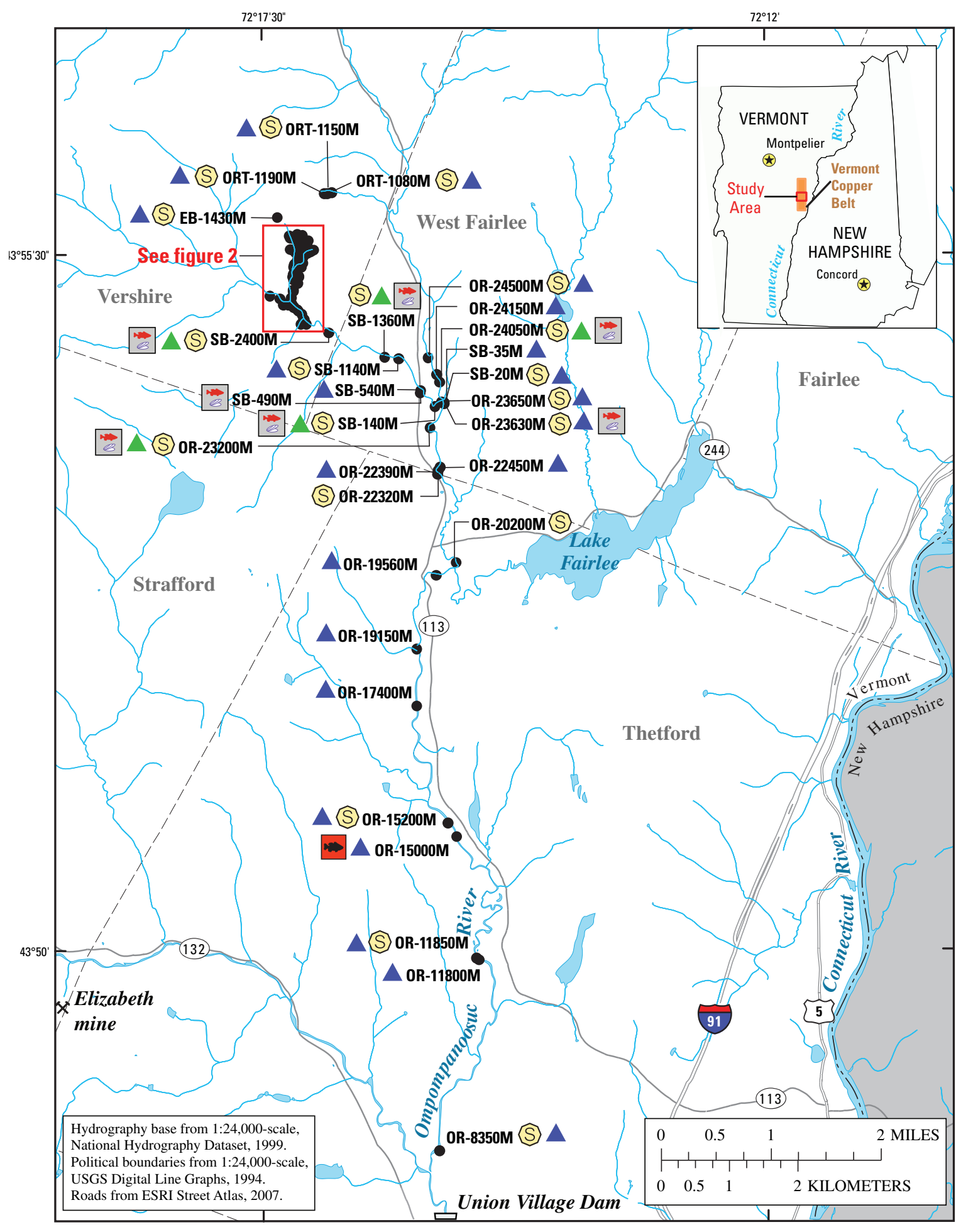

EXPLANATION

Symbols

Datasets

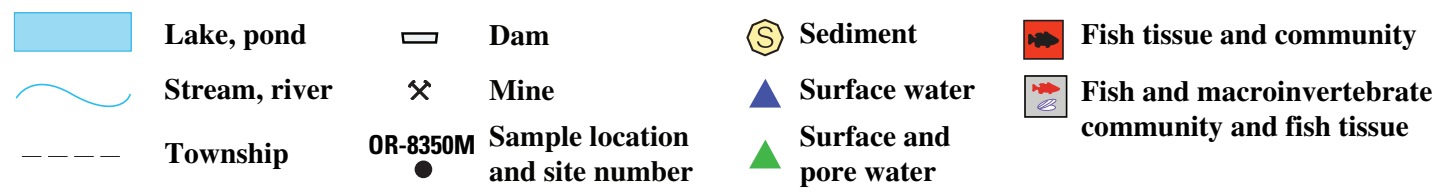

Figure 1. Sampling location numbers and identifiers for data collected in the Ompompanoosuc River and Schoolhouse Brook, Vershire, VT. Also shown are the locations of the Elizabeth Mine Superfund site, and the Union Village Dam just below the confluence of the West Branch of the Ompompanoosuc River with the Ompompanoosuc River. 


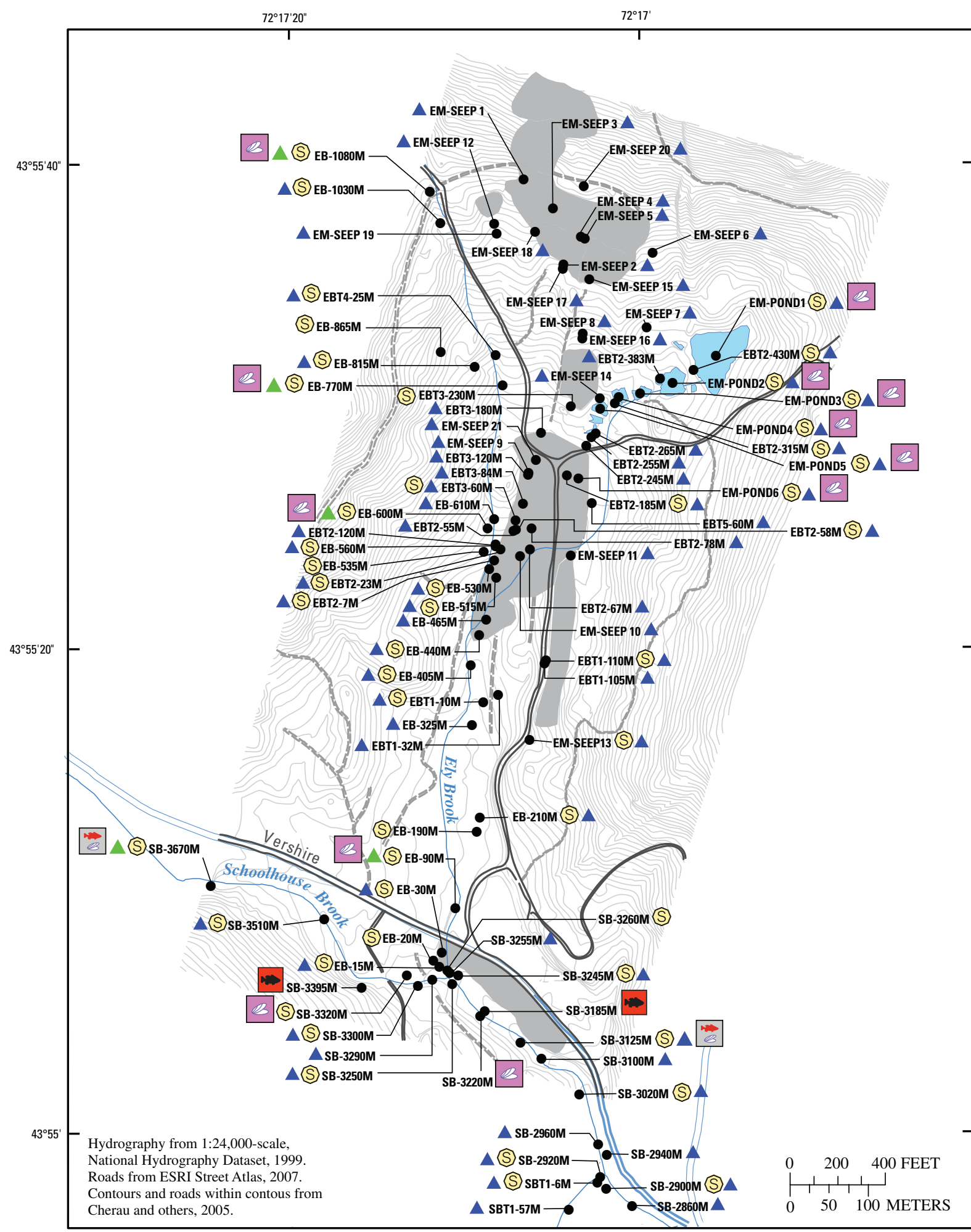

\section{EXPLANATION}

Symbols

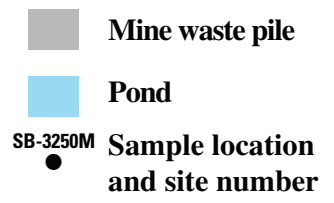
$\triangle$ Surface water
$\triangle$ Surface and pore water
(S) Sediment

Datasets

Fish tissue and community

Q Macroinvertebrate community
Fish and macroinvertebrate community and fish tissue

Figure 2. Sampling location numbers and identifiers for data collected at the Ely Mine Superfund site, Vershire, VT. 
mining activities between 1821 and 1920 with peak production in the 1870s and 1880s (Kierstead, 2001). Mining ceased in 1905, but during World War I, a flotation mill constructed onsite processed material from ore dumps. The property is currently owned by Ely Mine Forest, Inc., and Green Crow Corporation.

The site extends up the Ely Brook watershed to the crest of the ridge (fig. 2). Near the top of the ridge, a series of adits and inclined shafts accessed the ore body in a northeasterly direction. Extending downslope from the main shaft is a series of waste-rock piles and a small area of flotation tailings, followed by roast beds and finally the smelter site, including a large slag pile on the banks of Schoolhouse Brook. Two main tributaries combine to form Ely Brook. One tributary flows in a southerly direction from the area west of the mine workings; the other flows in a southwesterly direction through a series of ponds east of the mine workings. Both main tributaries converge in the lower waste piles to form the main channel of Ely Brook.

The Ely Mine site has been the subject of numerous geological and environmental studies, some of which predated the remedial investigation initiated by USEPA in 2000. Early summaries of the geology and mining history of the Ely Mine are provided by Wheeler (1883), Smyth and Smith (1904), Weed (1911), Buerger (1935), White and Eric (1944), Hermance and others (1949), and Abbott (1973). More recently, the geology of the Ely Mine has been described by Slack and others (1993; 2001) and Offield and others (1993), and the mining history has been discussed by Kierstead (2001) and Cherau and others (2005).

Environmental investigations at the site prior to placement on the National Priorities list include studies by the Vermont Agency of Natural Resources (ANR), the U.S. Bureau of Mines (USBM), and the USGS. The Vermont ANR evaluated the fish community around the site in 1988. The USBM conducted bench-scale pilot tests of passive treatment of acid-mine drainage at the site (McSurdy and others, 1995). The USGS presented preliminary results of investigations of mine-waste and mine-drainage characteristics (Hammarstrom and others, 2001a, b; Seal and others, 2001). They also investigated the environmental mineralogy and geochemistry of slag from the site (Piatak and others, 2003, 2004).

The remedial investigation, to date, has included a number of studies on the environmental characteristics and mining history of the site. At the request of the USEPA, the U.S. Army Corps of Engineers (USACE) and the USGS collaborated on a study on spring runoff in 2002 (Holmes and others, 2002). The USGS investigated the geochemical characteristics of mine waste at the Ely Mine (Piatak and others, 2004). In the course of the remedial investigations, the USEPA and its contractors have conducted surface-water $(2005,2006)$ and sediment (2000-2001, 2004, 2006) sampling and bioassays (2006) of surface waters [Agency for Toxic Substances and Disease Registry (ATSDR), 2008; TechLaw, 2008; URS Corporation, 2009]. The mining history of the site has also been summarized by Cherau and others (2005) as part of the remedial investigation.

\section{Study Approach and Methodology}

This study included a physical characterization of the water bodies in the Ely Mine study area; a chemical analysis of surface water, pore water, and sediment; toxicity testing of surface waters, pore waters, and bulk sediments; and a biological analysis of aquatic macroinvertebrate and fish assemblages. The purpose of analyzing these various components in the study was to provide an ecological evaluation that was more comprehensive than one based on the traditional triad approach of sediment chemistry, toxicity testing, and infaunal community composition (Long and Chapman, 1985). The study included 12 stream (lotic) locations, each delineated with a $100-\mathrm{m}$ sampling reach, and six pond (lentic) locations. Water samples were collected during August and September 2006. Surface-water samples were collected at the 12 stream locations: 4 on Ely Brook, 5 on Schoolhouse Brook, and 3 on the Ompompanoosuc River (figs. 1 and 2; table 1). Areas of sediment deposition were not found in 2 of the 12 stream locations, and therefore pore-water and sediment samples were collected at 10 stream locations: 4 on Ely Brook, 4 on Schoolhouse Brook, and 2 on the Ompompanoosuc River (figs. 1 and 2; table 1). During September 2006, benthic invertebrate assemblages were sampled, fish assemblages were surveyed, and fish tissue was collected for contaminant analysis. Within the stream reaches at 12 locations, macroinvertebrate assemblages were sampled in riffle habitats, and fish assemblages were surveyed and fish tissue collected along the reach; invertebrate assemblages in depositional habitats were sampled at 10 of these reaches (figs. 1 and 2; table 1). Surfacewater and sediment samples were collected at six ponds along a tributary to Ely Brook in September 2006. During October 2006, invertebrate assemblages were also sampled in six hydraulically connected ponds located within the watershed of the mine (figs. 1 and 2; table 1).

\section{Selection of Sample Locations}

A qualitative geomorphologic characterization of stream segments in Ely Brook, Schoolhouse Brook, and the Ompompanoosuc River was conducted in June 2006 to assist in determining optimum stream sampling locations where the collection and analysis of surface water, pore water, sediment, macroinvertebrates, and fish would provide an understanding of the relative magnitude of contaminants at the site and their effects on aquatic biota. Based on the characterization, sampling locations were selected to provide a more holistic understanding of the differences in surface water, pore water, and sediment chemistry in a stream system affected by acidrock drainage and the effects to aquatic biota. Where possible, samples were obtained in stream reaches that contained areas of deposition (pools) and areas of greater velocity (riffles).

Latitudes and longitudes for the geomorphologic characterization were determined with a 10-hertz (Hz) Trimble AgGPS 132 receiver and integrated with ESRI ArcMap 
Table 1. Select characteristics for sampling locations at the Ely Mine study area, Vershire, VT.

[URS, URS Corporation; CRREL, U.S. Army Corps of Engineers Cold Regions Research and Engineering Laboratory; ADL, Arthur D. Little, Incorporated; EPA, U.S. Environmental Protection Agency; USGS, U.S. Geological Survey; latitude and longitude are given in decimal degrees; SW, surface water; Sed, sediment; PW, pore water; B, benthic invertebrate; F, fish; Tox, toxicity test]

\begin{tabular}{|c|c|c|c|c|c|c|c|}
\hline Site number & Stream & $\begin{array}{l}\text { River } \\
\text { meter }^{\mathrm{a}}\end{array}$ & Latitude & Longitude & Datasets & Historical name & $\begin{array}{l}\text { Sampling } \\
\text { organization }\end{array}$ \\
\hline EB-15M & Ely Brook & 15 & 43.91857 & -72.28655 & SW, Sed & $\begin{array}{l}\text { EB-6, ELYM-8-SS, } \\
\text { EB-PPT }\end{array}$ & CRREL, USGS \\
\hline EB-20M & Ely Brook & 20 & 43.91864 & -72.28664 & Sed & 06Ely11 & USGS \\
\hline EB-30M & Ely Brook & 30 & 43.91873 & -72.28651 & SW, Sed & SW-09, SED-09 & URS \\
\hline EB-90M & Ely Brook & 90 & 43.91924 & -72.28629 & $\begin{array}{l}\text { SW, PW, Sed, } \\
\text { B, Tox }\end{array}$ & $\begin{array}{c}\text { Site 4, 06Ely04, EB7, } \\
\text { EMTT-3, LOC-49 }\end{array}$ & $\begin{array}{l}\text { USGS, EPA, } \\
\text { ADL }\end{array}$ \\
\hline EB-190M & Ely Brook & 190 & 43.92012 & -72.28595 & Sed & SED5 & EPA \\
\hline EB-210M & Ely Brook & 210 & 43.92028 & -72.28590 & SW, Sed & SW-10, SED-10 & URS \\
\hline \multirow[t]{2}{*}{ EB-325M } & Ely Brook & 325 & 43.92134 & -72.28601 & SW & SW-39 & URS \\
\hline & Ely Brook & 350 & \multicolumn{5}{|c|}{ Confluence with Ely Brook Tributary 1} \\
\hline EB-405M & Ely Brook & 405 & 43.92203 & -72.28604 & SW, Sed & SW-33, SED-33 & URS \\
\hline EB-440M & Ely Brook & 440 & 43.92237 & -72.28590 & SW, Sed & LOC-59, SW-11 SED-11 & ADL, URS \\
\hline EB-465M & Ely Brook & 465 & 43.92255 & -72.28579 & SW & EB-5 & CRREL \\
\hline EB-515M & Ely Brook & 515 & 43.92303 & -72.28563 & SW & EB5, SED4 & EPA \\
\hline EB-530M & Ely Brook & 530 & 43.92313 & -72.28574 & SW, Sed & SW-12, SED-12 & URS \\
\hline \multirow[t]{2}{*}{ EB-535M } & Ely Brook & 535 & 43.92333 & -72.28583 & Sed & ELY-EB-SS & USGS \\
\hline & Ely Brook & 540 & \multicolumn{5}{|c|}{ Confluence with Ely Brook Tributary 2} \\
\hline EB-560M & Ely Brook & 560 & 43.92339 & -72.28564 & SW, Sed & SW-13, SED-13 & URS \\
\hline EB-600M & Ely Brook & 600 & 43.92360 & -72.28576 & SW, PW, Sed, B & Site 3, 06Ely03 & USGS \\
\hline EB-610M & Ely Brook & 610 & 43.92370 & -72.28566 & SW & LOC-57 & $\mathrm{ADL}$ \\
\hline \multirow[t]{2}{*}{ EB-770M } & Ely Brook & 770 & 43.92524 & -72.28552 & SW, PW, Sed, B & Site 2, 06Ely02, SW-40 & USGS, URS \\
\hline & Ely Brook & 800 & \multicolumn{5}{|c|}{ Confluence with Ely Brook Tributary 4} \\
\hline EB-815M & Ely Brook & 815 & 43.92545 & -72.28596 & SW, Sed & SW-17, SED-17 & URS \\
\hline EB-865M & Ely Brook & 865 & 43.92562 & -72.28650 & Sed & SED3 & EPA \\
\hline EB-1030M & Ely Brook & 1,030 & 43.92710 & -72.28650 & SW, Sed & SW-18, SED-18 & URS \\
\hline EB-1080M & Ely Brook & 1,080 & 43.92746 & -72.28667 & SW, PW, Sed, B & $\begin{array}{l}\text { EB-1, Site 1, 06Ely01, } \\
\text { SED1 }\end{array}$ & $\begin{array}{l}\text { CRREL, USGS, } \\
\text { EPA }\end{array}$ \\
\hline EB-1430M & Ely Brook & 1,430 & 43.92984 & -72.28875 & SW, Sed & SW-20, SED-20 & URS \\
\hline EBT1-10M & Ely Brook Trib 1 & 10 & 43.92160 & -72.28584 & SW, Sed & SW-34, SED-34 & URS \\
\hline EBT1-32M & Ely Brook Trib 1 & 32 & 43.92169 & -72.28560 & SW & EB6 & EPA \\
\hline EBT1-105M & Ely Brook Trib 1 & 105 & 43.92204 & -72.28487 & SW & EB-7 & CRREL \\
\hline EBT1-110M & Ely Brook Trib 1 & 110 & 43.92208 & -72.28484 & SW, Sed & SW-36, SED-36 & URS \\
\hline EBT2-7M & Ely Brook Trib 2 & 7 & $43 . \overline{92323}$ & -72.28566 & SW, Sed & SW-32, SED-32 & URS \\
\hline \multirow[t]{2}{*}{ ЕВT2-23M } & Ely Brook Trib 2 & 23 & 43.92336 & -72.28556 & SW, Sed & SW-31, SED-31 & URS \\
\hline & Ely Brook Trib 2 & 50 & \multicolumn{5}{|c|}{ Confluence with Ely Brook Tributary 3} \\
\hline EBT2-55M & Ely Brook Trib 2 & 55 & 43.92357 & -72.28535 & SW & EB3 & EPA \\
\hline EBT2-58M & Ely Brook Trib 2 & 58 & 43.92358 & -72.28531 & SW, Sed & SW-14, SED-14 & URS \\
\hline EBT2-67M & Ely Brook Trib 2 & 67 & 43.92336 & -72.28509 & SW & LOC-58 & $\mathrm{ADL}$ \\
\hline EBT2-78M & Ely Brook Trib 2 & 78 & 43.92359 & -72.28507 & SW & EB-3 & CRREL \\
\hline \multirow[t]{2}{*}{ EBT2-120M } & Ely Brook Trib 2 & 120 & 43.92341 & -72.28564 & SW & EB4 & $\mathrm{EPA}$ \\
\hline & Ely Brook Trib 2 & 125 & \multicolumn{5}{|c|}{ Confluence with Ely Brook Tributary 5} \\
\hline
\end{tabular}


Table 1. Select characteristics for sampling locations at the Ely Mine study area, Vershire, VT._Continued

[URS, URS Corporation; CRREL, U.S. Army Corps of Engineers Cold Regions Research and Engineering Laboratory; ADL, Arthur D. Little, Incorporated; EPA, U.S. Environmental Protection Agency; USGS, U.S. Geological Survey; latitude and longitude are given in decimal degrees; SW, surface water; Sed, sediment; PW, pore water; B, benthic invertebrate; F, fish; Tox, toxicity test]

\begin{tabular}{|c|c|c|c|c|c|c|c|}
\hline Site number & Stream & $\begin{array}{l}\text { River } \\
\text { meter }^{\mathrm{a}}\end{array}$ & Latitude & Longitude & Datasets & Historical name & $\begin{array}{c}\text { Sampling } \\
\text { organization }\end{array}$ \\
\hline EBT2-185M & Ely Brook Trib 2 & 185 & 43.92420 & -72.28450 & SW,Sed & SW-37, SED-37 & URS \\
\hline EM-POND6 & Pond & 195 & 43.92417 & -72.28432 & SW, Sed, B, Tox & Pond 6, 06ElyPond6 & USGS, EPA \\
\hline EBT2-245M & Ely Brook Trib 2 & 245 & 43.92454 & -72.28419 & Tox & EMTT-2 & EPA \\
\hline EBT2-255M & Ely Brook Trib 2 & 255 & 43.92464 & -72.28411 & SW & SW-41 & URS \\
\hline EBT2-265M & Ely Brook Trib 2 & 265 & 43.92468 & -72.28404 & SW & EB-2 & CRREL \\
\hline EM-POND5 & Pond & 290 & 43.92497 & -72.28397 & SW, Sed, B, Tox & Pond 5, 06ElyPond5 & USGS, EPA \\
\hline EBT2-315M & Ely Brook Trib 2 & 315 & 43.92503 & -72.28374 & SW, Sed & SW-16, SED-16 & URS \\
\hline EM-POND4 & Pond & 320 & 43.92510 & -72.28368 & SW, Sed, B, Tox & $\begin{array}{l}\text { Pond 4, 06ElyPond4, } \\
\text { EMTT-1 REF }\end{array}$ & USGS, EPA \\
\hline EM-POND3 & Pond & 345 & 43.92514 & -72.28334 & SW, Sed, B, Tox & Pond 3, 06ElyPond3 & USGS, EPA \\
\hline EBT2-383M & Ely Brook Trib 2 & 383 & 43.92531 & -72.28302 & SW & EB-2a & CRREL \\
\hline EM-POND2 & Pond & 385 & 43.92526 & -72.28282 & SW, Sed, B, Tox & Pond 2, 06ElyPond2 & USGS, EPA \\
\hline EBT2-430M & Ely Brook Trib 2 & 430 & 43.92541 & -72.28249 & SW, Sed & SW-21, SED-21 & URS \\
\hline EM-POND1 & Pond & 432 & 43.92557 & -72.28213 & SW, Sed, B & Pond 1,06 ElyPond 1 & USGS \\
\hline$\overline{\text { EBT3-60M }}$ & Ely Brook $\overline{\text { Trib }} 3$ & 60 & $43 . \overline{92369}$ & -72.28532 & SW, Sed & SW-30, SED-30 & URS \\
\hline EBT3-84M & Ely Brook Trib 3 & 84 & 43.92388 & -72.28520 & SW & EB-4 & CRREL \\
\hline EBT3-120M & Ely Brook Trib 3 & 120 & 43.92421 & -72.28512 & SW & $\mathrm{EB} 2$ & EPA \\
\hline EBT3-180M & Ely Brook Trib 3 & 180 & 43.92469 & -72.28491 & SW & EB1 & EPA \\
\hline EBT3-230M & Ely Brook Trib 3 & 230 & 43.92500 & -72.28444 & Sed & ELY-SS-2 & USGS \\
\hline EBT4-25M & Ely Brook $\overline{\text { Trib }} 4$ & 25 & $43 . \overline{92558}$ & -72.28563 & SW, Sed & SW-29, SED-29 & URS \\
\hline EBT5-60M & Ely Brook Trib 5 & 60 & $43 . \overline{923} 88$ & -72.28411 & SW & SW-51 & URS \\
\hline SB-20M & Schoolhouse Bk & 20 & $43 . \overline{90535}$ & -72.25874 & SW, Sed, Tox & SW-27, SED-27, EMTT-8 & URS, EPA \\
\hline SB-35M & Schoolhouse Bk & 35 & 43.90549 & -72.25894 & SW & SB11 & EPA \\
\hline SB-140M & Schoolhouse Bk & 140 & 43.90490 & -72.26012 & $\begin{array}{l}\text { SW, PW, Sed, } \\
\text { B, F, Tox }\end{array}$ & Site 5, 06Ely08, SED9 & USGS, EPA \\
\hline SB-490M & Schoolhouse Bk & 490 & 43.90670 & -72.26280 & $\mathrm{~B}, \mathrm{~F}$ & Ely Bk station 0.4, F-17 & ADL \\
\hline SB-540M & Schoolhouse Bk & 540 & 43.90699 & -72.26271 & SW & SB-3 & CRREL \\
\hline SB-1140M & Schoolhouse Bk & 1,140 & 43.91121 & -72.26672 & SW, Sed & LOC-52 & ADL \\
\hline SB-1360M & Schoolhouse Bk & 1,360 & 43.91144 & -72.26925 & $\begin{array}{l}\text { SW, PW, Sed, } \\
\text { B, F, Tox }\end{array}$ & $\begin{array}{l}\text { Site 4, 06Ely07, SW-01, } \\
\text { SED-01 }\end{array}$ & USGS, URS \\
\hline SB-2400M & Schoolhouse Bk & 2,400 & 43.91460 & -72.27950 & $\begin{array}{l}\text { SW, PW, Sed, } \\
\text { B, F, Tox }\end{array}$ & Site 3, 06Ely06, SED8 & USGS, EPA \\
\hline SB-2860M & Schoolhouse Bk & 2,860 & 43.91582 & -72.28350 & Tox & EMTT-7 & EPA \\
\hline \multirow[t]{2}{*}{ SB-2900M } & Schoolhouse Bk & 2,900 & 43.91602 & -72.28391 & SW, Sed & SW-02, SED-02 & URS \\
\hline & Schoolhouse Bk & 2,915 & \multicolumn{4}{|c|}{ Confluence with Schoolhouse Brook Tributary } & \\
\hline SB-2920M & Schoolhouse Bk & 2,920 & 43.91615 & -72.28400 & SW, Sed & SW-03, SED-03 & URS \\
\hline SB-2940M & Schoolhouse Bk & 2,940 & 43.91641 & -72.28390 & SW & SB-2 & CRREL \\
\hline SB-2960M & Schoolhouse Bk & 2,960 & 43.91653 & -72.28403 & SW & LOC-51 & ADL \\
\hline SB-3020M & Schoolhouse Bk & 3,020 & 43.91710 & -72.28433 & SW, Sed & SW-04, SED-04 & URS \\
\hline SB-3100M & Schoolhouse Bk & 3,100 & 43.91751 & -72.28493 & SW, Tox & SB9, ЕMTT-6 & EPA \\
\hline SB-3125M & Schoolhouse Bk & 3,125 & 43.91770 & -72.28526 & SW, B, F, Tox & $\begin{array}{l}\text { Site 2, 06Ely19, SED7, } \\
\text { SW-05, SED-05 }\end{array}$ & $\begin{array}{l}\text { USGS, EPA, } \\
\text { URS }\end{array}$ \\
\hline
\end{tabular}


Table 1. Select characteristics for sampling locations at the Ely Mine study area, Vershire, VT.-Continued

[URS, URS Corporation; CRREL, U.S. Army Corps of Engineers Cold Regions Research and Engineering Laboratory; ADL, Arthur D. Little, Incorporated; EPA, U.S. Environmental Protection Agency; USGS, U.S. Geological Survey; latitude and longitude are given in decimal degrees; SW, surface water; Sed, sediment; PW, pore water; B, benthic invertebrate; F, fish; Tox, toxicity test]

\begin{tabular}{|c|c|c|c|c|c|c|c|}
\hline Site number & Stream & $\begin{array}{l}\text { River } \\
\text { meter }^{\text {a }}\end{array}$ & Latitude & Longitude & Datasets & Historical name & $\begin{array}{c}\text { Sampling } \\
\text { organization }\end{array}$ \\
\hline SB-3185M & Schoolhouse Bk & 3,185 & 43.91806 & -72.28583 & $\mathrm{~F}$ & F-18 & ADL \\
\hline SB-3220M & Schoolhouse Bk & 3,220 & 43.91800 & -72.28590 & $\mathrm{~B}$ & Ely Bk station 2.2 & ADL \\
\hline SB-3245M & Schoolhouse Bk & 3,245 & 43.91847 & -72.28625 & Sed, Tox & ELYM-10-SS, EMTT-5 & USGS, EPA \\
\hline SB-3250M & Schoolhouse Bk & 3,250 & 43.91837 & -72.28634 & SW, Sed & SW-06, SED-06 & URS \\
\hline SB-3255M & Schoolhouse Bk & 3,255 & 43.91850 & -72.28638 & SW & SB8 & EPA \\
\hline \multirow[t]{2}{*}{ SB-3260M } & Schoolhouse Bk & 3,260 & 43.91853 & -72.28642 & Sed & 06Ely 12 & USGS \\
\hline & Schoolhouse Bk & 3,270 & \multicolumn{3}{|c|}{ Confluence with Ely Brook } & & \\
\hline SB-3290M & Schoolhouse Bk & 3,290 & 43.91842 & -72.28666 & SW & SB-1, SW-38 & CRREL, URS \\
\hline SB-3300M & Schoolhouse Bk & 3,300 & 43.91835 & -72.28689 & SW, Sed & LOC-48 & ADL \\
\hline SB-3320M & Schoolhouse Bk & 3,320 & 43.91847 & -72.28706 & Sed, B & $\begin{array}{l}\text { ELYM-9-SS, Ely Bk } \\
\quad \text { station } 2.3\end{array}$ & USGS, ADL \\
\hline SB-3395M & Schoolhouse Bk & 3,395 & 43.91833 & -72.28778 & $\mathrm{~F}$ & F-19 & $\mathrm{ADL}$ \\
\hline SB-3510M & Schoolhouse Bk & 3,510 & 43.91911 & -72.28838 & SW, Sed & SW-07, SED-07 & URS \\
\hline SB-3670M & Schoolhouse Bk & 3,670 & 43.91951 & -72.29015 & $\begin{array}{l}\text { SW, PW, Sed, } \\
\text { B, F, Tox }\end{array}$ & $\begin{array}{l}\text { Site 1, 06Ely05, SED6, } \\
\text { EMTT-4 }\end{array}$ & USGS, EPA \\
\hline SBT1-6M & Schoolhouse Bk Trib & 6 & 43.91609 & -72.28405 & SW, Sed & SW-25, SED-25 & URS \\
\hline SBT1-57M & Schoolhouse Bk Trib & 57 & 43.91578 & -72.28450 & SW & LOC-50 & \multirow[t]{2}{*}{$\mathrm{ADL}$} \\
\hline OR-8350M & Ompompanoosuc River & 8,350 & 43.80691 & -72.25970 & SW, Sed & LOC-45 & \\
\hline OR-11800M & Ompompanoosuc River & 11,800 & 43.83198 & -72.25245 & SW & OM14 & EPA \\
\hline OR-11850M & Ompompanoosuc River & 11,850 & 43.83226 & -72.25290 & SW, Sed & LOC-35 & ADL \\
\hline OR-15000M & Ompompanoosuc River & 15,000 & 43.84826 & -72.25645 & SW, F & OR-3, F-11 & CRREL, ADL \\
\hline OR-15200M & Ompompanoosuc River & 15,200 & 43.85003 & -72.25800 & SW, Sed & LOC-56 & $\mathrm{ADL}$ \\
\hline OR-17400M & Ompompanoosuc River & 17,400 & 43.86544 & -72.26366 & SW & LOC-55 & ADL \\
\hline OR-19150M & Ompompanoosuc River & 19,150 & 43.87300 & -72.26360 & SW & LOC-54 & $\mathrm{ADL}$ \\
\hline OR-19560M & Ompompanoosuc River & 19,560 & 43.88272 & -72.26152 & SW & OM13 & EPA \\
\hline OR-20200M & Ompompanoosuc River & 20,200 & 43.88430 & -72.25637 & Sed & SED13 & EPA \\
\hline OR-22320M & Ompompanoosuc River & 22,320 & 43.89595 & -72.25971 & Sed & SED12 & EPA \\
\hline OR-22390M & Ompompanoosuc River & 22,390 & 43.89647 & -72.25965 & SW & OM12 & EPA \\
\hline OR-22450M & Ompompanoosuc River & 22,450 & 43.89691 & -72.25925 & SW & OR-2 & CRREL \\
\hline OR-23200M & Ompompanoosuc River & 23,200 & 43.90215 & -72.26101 & $\begin{array}{l}\text { SW, PW, Sed, } \\
\quad \text { B, F, Tox }\end{array}$ & Site 3, 06Ely10, SED11 & USGS, EPA \\
\hline \multirow[t]{2}{*}{ OR-23630M } & Ompompanoosuc River & 23,630 & 43.90521 & -72.25854 & SW, B, F, Tox & $\begin{array}{l}\text { Site 2, 06Ely20, SW-28, } \\
\quad \text { SED-28 }\end{array}$ & USGS, URS \\
\hline & Ompompanoosuc River & 23,640 & \multicolumn{3}{|c|}{ Confluence with Schoolhouse Brook } & & \\
\hline OR-23650M & Ompompanoosuc River & 23,650 & 43.90541 & -72.25855 & SW, Sed & SW-26, SED-26 & URS \\
\hline OR-24050M & Ompompanoosuc River & 24,050 & 43.90812 & -72.25928 & $\begin{array}{l}\text { SW, PW, Sed, } \\
\text { B, F, Tox }\end{array}$ & $\begin{array}{l}\text { Site 1, 06Ely09, SED10, } \\
\text { F-13 }\end{array}$ & $\begin{array}{l}\text { USGS, EPA, } \\
\text { ADL }\end{array}$ \\
\hline OR-24150M & Ompompanoosuc River & 24,150 & 43.90915 & -72.25990 & SW & OR-1 & CRREL \\
\hline OR-24500M & Ompompanoosuc River & 24,500 & 43.91132 & -72.26134 & SW, Sed & LOC-53 & $\mathrm{ADL}$ \\
\hline & Ompompanoosuc River & 27,450 & Confl & nee with $\mathrm{Om}_{1}$ & ompanoosuc R & r Tributary & \\
\hline
\end{tabular}


Table 1. Select characteristics for sampling locations at the Ely Mine study area, Vershire, VT.-Continued

[URS, URS Corporation; CRREL, U.S. Army Corps of Engineers Cold Regions Research and Engineering Laboratory; ADL, Arthur D. Little, Incorporated; EPA, U.S. Environmental Protection Agency; USGS, U.S. Geological Survey; latitude and longitude are given in decimal degrees; SW, surface water; Sed, sediment; PW, pore water; B, benthic invertebrate; F, fish; Tox, toxicity test]

\begin{tabular}{|c|c|c|c|c|c|c|c|}
\hline Site number & Stream & $\begin{array}{c}\text { River } \\
\text { meter }^{\mathrm{a}}\end{array}$ & Latitude & Longitude & Datasets & Historical name & $\begin{array}{c}\text { Sampling } \\
\text { organization }\end{array}$ \\
\hline ORT-1080M & Ompompanoosuc R Trib & 1,080 & 43.93313 & -72.27888 & SW, Sed & SW-24, SED-24 & URS \\
\hline ORT-1150M & Ompompanoosuc R Trib & 1,150 & 43.93301 & -72.27968 & SW, Sed & SW-23, SED-23 & URS \\
\hline ORT-1190M & Ompompanoosuc R Trib & 1,190 & 43.93303 & -72.28025 & SW, Sed & SW-22, SED-22 & URS \\
\hline EM-SEEP1 & Seep & & $43 . \overline{927} 60$ & -72.28518 & SW & ES-1 & CRREL \\
\hline EM-SEEP2 & Seep & & 43.92662 & -72.28455 & SW & ES-2 & CRREL \\
\hline EM-SEEP3 & Seep & & 43.92726 & -72.28471 & SW & ES-3 & CRREL \\
\hline EM-SEEP4 & Seep & & 43.92694 & -72.28427 & SW & ES-4 & CRREL \\
\hline EM-SEEP5 & Seep & & 43.92692 & -72.28421 & SW & ES-5 & CRREL \\
\hline EM-SEEP6 & Seep & & 43.92675 & -72.28313 & SW & ES-6 & CRREL \\
\hline EM-SEEP7 & Seep & & 43.92590 & -72.28323 & SW & ES-7 & CRREL \\
\hline EM-SEEP8 & Seep & & 43.92583 & -72.28424 & SW & ES-8 & CRREL \\
\hline EM-SEEP9 & Seep & & 43.92423 & -72.28511 & SW & ES-9 & CRREL \\
\hline EM-SEEP10 & Seep & & 43.92328 & -72.28525 & SW & ES-10 & CRREL \\
\hline EM-SEEP11 & Seep & & 43.92328 & -72.28444 & SW & ES-11 & CRREL \\
\hline EM-SEEP12 & Seep & & 43.92709 & -72.28565 & SW & ES-12 & CRREL \\
\hline EM-SEEP13 & Seep & & 43.92117 & -72.28511 & SW, Sed & SW-35, SED-35 & URS \\
\hline EM-SEEP14 & Seep & & 43.92509 & -72.28398 & SW & SW-42 & URS \\
\hline EM-SEEP15 & Seep & & 43.92645 & -72.28414 & SW & SW-43 & URS \\
\hline EM-SEEP16 & Seep & & 43.92577 & -72.28425 & SW & SW-45 & URS \\
\hline EM-SEEP17 & Seep & & 43.92657 & -72.28456 & SW & SW-46 & URS \\
\hline EM-SEEP18 & Seep & & 43.92700 & -72.28500 & SW & SW-47 & URS \\
\hline EM-SEEP19 & Seep & & 43.92698 & -72.28561 & SW & SW-48 & URS \\
\hline EM-SEEP20 & Seep & & 43.92752 & -72.28422 & SW & SW-49 & URS \\
\hline EM-SEEP21 & Seep & & 43.92438 & -72.28499 & SW & SW-52 & URS \\
\hline
\end{tabular}

\footnotetext{
a River meter zero is located at the stream mouth.
} 
software. A differential global positioning system (DGPS) location was output to the software each second. Sub-meter DGPS accuracy was achieved using a differential signal from the Wide Area Augmentation System (WAAS).

Stream morphology and substrate type were qualitatively assessed and are presented in appendix 1. Stream morphology (riffle, run, pool, or cascade) was determined as described in Fitzpatrick and others (1998). Emphasis was given to delineating areas of deposition. Substrate type (sand, gravel, cobble, or boulder) was qualitatively assessed in the field and determined on the basis of observed particle size as described by Arcement and Schneider (1989).

Sample locations were named using a river-meter method and an abbreviation for the particular reach (EB for Ely Brook, SB for Schoolhouse Brook, and OR for Ompompanoosuc River). The river-meter method refers to the sample location in distance upstream of the mouth, in meters. For example, EB-90M refers to a sample location on Ely Brook 90 meters upstream of the mouth.

\section{Hydrologic Data}

Instantaneous streamflow measurements were made at all water sampling locations. Streamflow was measured by the conventional current-meter method or by use of a portable Parshall flume using published USGS protocols (Buchanan and Somers, 1969; Rantz and others, 1982; Kilpatrick and Schneider, 1983). Error associated with a streamflow measurement made by the current-meter method in the Ompompanoosuc River and Schoolhouse Brook was calculated using protocols developed by Sauer and Meyer (1992). Error associated with a streamflow measurement made by the Parshall flume in Ely Brook was assumed to be equal to half the difference in the rated discharges per unit increase in observed stage. Error associated with streamflow measurements made by the current-meter method was less than 5 percent, and those made by Parshall flume were less than 15 percent.

\section{Surface-Water Data}

Surface-water samples were collected using standard USGS protocols (Wilde and Radtke, 1998; Wilde and others, 1999). Specific conductance, $\mathrm{pH}$, and water temperature were determined by discrete measurements at the time of watersample collection. Water samples were collected for the analysis of major ions, trace elements, nutrients, dissolved organic carbon, and suspended sediment. Samples were analyzed for major ions and trace elements by the USGS Analytical Chemistry Services Group in Denver, CO. Trace elements were analyzed using inductively coupled plasma-atomic emission spectroscopy (ICP-AES) and inductively coupled plasma-mass spectrometry (ICP-MS). Mercury was analyzed using continuous-flow cold-vapor atomic absorption spectrometry. Major anions were analyzed using ion chromatography. Samples for trace elements and major ions included a less than 0.45-micrometer $(\mu \mathrm{m})$ filtered (dissolved) sample and an unfiltered (total) sample. Samples were analyzed for nutrients and dissolved organic carbon by the USGS National WaterQuality Laboratory in Denver, CO. Samples were analyzed for suspended sediments by the USGS Sediment Laboratory in Louisville, KY.

\section{Pore-Water Data}

Pore-water samples were obtained using three different methodologies. Pore water was extracted from sediment in situ using protocols described in Zimmerman and others (2005), extracted via centrifugation in the laboratory, and collected passively using separation by gravity from samples that aged or equilibrated 28 days in the laboratory. Pore-water physical properties and chemical data were collected using USGS protocols (Shelton and Capel, 1994). In situ pore-water samples were collected with the use of a push-point sampler at a depth of 15 centimeters $(\mathrm{cm})$. A push-point sampler is designed to sample sediment pore water with minimal disturbance to the site. Specific conductance of sampled water was used to monitor gross chemical differences between surface water and pore water during sampling and to identify the presence of drawdown. Samples were analyzed for major ions and trace elements by the USGS Analytical Chemistry Services Group in Denver, CO. Trace elements were analyzed using ICP-AES and ICP-MS. Mercury was analyzed using continuous-flow cold-vapor atomic absorption spectrometry. Major anions were analyzed using ion chromatography. Samples for trace elements and major ions included a less-than- $0.45-\mu \mathrm{m}$ filtered (dissolved) sample and an unfiltered (total) sample. Samples were analyzed for nutrients and dissolved organic carbon by the USGS National Water-Quality Laboratory in Denver, CO. An aliquot of each pore-water sample collected by push-point sampling was submitted to the USEPA New England Regional Laboratory in North Chelmsford, MA, for use in 96-hour toxicity tests using Chironomus dilutus and Hyalella azteca. Methods and results of this testing are described in a report prepared by TechLaw under contract to the USEPA (TechLaw, Inc., 2006a).

Two additional types of samples were collected to evaluate pore-water chemistry. Subsamples of the sediments used for toxicity testing were centrifuged in the laboratory to obtain water for analysis. In addition, 2-L bottles were filled with sediments and topped off with stream water from the sample site. These samples were allowed to age or equilibrate in the lab for 28 days, at which point water was drained by gravity from the sediment sample for analysis.

\section{Sediment Data}

Streambed sediment samples were collected according to USGS protocols (Hammarstrom and others, 2003). Samples were collected in areas of deposition that coincided with porewater sampling locations and analyzed for trace elements, 
simultaneously extractable metals-acid volatile sulfide (SEMAVS), grain size, total organic carbon (TOC), cation-exchange capacity, and ash-free dry weight. Samples were collected from undisturbed, continuously wetted depositional zones in the stream channel. The top $10 \mathrm{~cm}$ of streambed sediment were sampled to obtain only the most recently deposited material. Composited samples were collected with 5 to 10 representative subsamples located across the stream channel. Samples were analyzed for trace elements using ICP-AES, TOC using an elemental analyzer, and mercury using continuous-flow cold-vapor atomic absorption spectrometry by the USGS Analytical Chemistry Services Group in Denver, CO. Samples were analyzed for SEM-AVS and grain size by Severn Trent Laboratory in Colchester, VT.

Potential sediment toxicity can be assessed either by comparing sediment geochemical concentrations to a probable effects concentration for various elements (PEC; MacDonald and others, 2000) or by investigating the equilibriumpartitioning sediment benchmark (ESB). The PEC for each chemical represents a concentration above which toxicity has been observed in toxicity tests from many sites. The ESB is defined as the molar difference between the combined simultaneously extractable metals ( $\mathrm{SEM}$; $\mathrm{Cd}+\mathrm{Cu}+\mathrm{Ni}+\mathrm{Pb}+\mathrm{Zn}$ ) and the acid volatile sulfide (AVS), normalized to the fraction of organic carbon (OC) on a mass basis $\left(\mathrm{f}_{\mathrm{OC}}\right.$; [ [SEM-AVS]/ $\mathrm{f}_{\text {OC }}$; Di Toro and others, 2005; USEPA, 2005).

\section{Macroinvertebrate Data}

Macroinvertebrate samples were collected to coincide with water-chemistry sampling locations. The procedures in the USGS protocols for collecting biological samples (Moulton and others, 2002) were followed with some minor modifications described below that were based on State of Vermont protocols [Vermont Department of Environmental Conservation (VTDEC), 2006]. Because this study was designed to characterize the nature and extent of acid-mine drainage within the aquatic system, three different types of invertebrate samples were collected, each of which was specific to the habitat being sampled. The first of these samples was from areas representative of a riffle-targeted habitat (RTH) to characterize the effects of contaminants in surface water on invertebrate assemblage structure. The second of these samples was from areas representative of a depositional-targeted habitat (DTH), such as pools, to characterize the effects of contaminants in depositional sediments and interstitial pore water on invertebrate assemblage structure. At 10 of the 12 stream-reach locations, RTH and DTH samples were closely paired to assess the condition of the epifaunal (RTH) and infaunal (DTH) invertebrate assemblage. The purpose of using these two sample types was to determine if the degree of impairment from acidmine drainage differed in the two assemblage types. The State of Vermont Bioassessment Program uses epifaunal assemblage data collected from riffle areas as the basis for stream assessments in lotic habitats (VTDEC, 2006), whereas the USEPA
Superfund program emphasizes the ecological importance of assessing infauna in the depositional areas, because contaminated sediments tend to collect in the slow-flowing areas.

A third type of invertebrate sample, collected from the ponds, was a qualitative multi-habitat $(\mathrm{QMH})$ sample. The QMH samples characterized the epifaunal invertebrate assemblages that were most closely associated with the vegetation along the littoral areas of the ponds, which typically supports assemblages with the greatest abundance and diversity in lentic systems.

RTH samples were collected using a Slack sampler with a $500-\mu \mathrm{m}$ mesh designed to cover 0.25 square meter $\left(\mathrm{m}^{2}\right)$ of substrate area (Moulton and others, 2002). At each location, invertebrates were collected at four locations in a swift-

flowing area of a sampling reach, and these four samples were composited to represent the invertebrate assemblage on a $1-\mathrm{m}^{2}$ area of substrate. This procedure is a slight deviation from the USGS protocol, which specifies a composite from five locations $\left(1.25 \mathrm{~m}^{2}\right)$, but the change was made so that the assemblage data would conform to the method used by the VTDEC for high-gradient streams (VTDEC, 2006), and therefore be amenable to the bioassessment procedures used by VTDEC.

DTH samples of infaunal invertebrates were collected with a PVC coring device designed to sample the top $10 \mathrm{~cm}$ of sediment in an area of approximately 100 square centimeters $\left(\mathrm{cm}^{2}\right)$. At each location, sediments were sampled at five locations in depositional areas of a sampling reach, and these five samples were composited to represent the infaunal assemblage on a $500-\mathrm{cm}^{2}$ area of substrate. Sediment samples were collected by pushing the coring device into the sediment and then working a mason's trowel through the sediment to close off the bottom.

QMH samples were collected in the littoral areas along the edges of the ponds that were dominated by vegetation, wood snags, or both, to characterize the invertebrate assemblage structure within the pond. The QMH samples were collected with an invertebrate kick-net sampler with a 500- $\mu \mathrm{m}$ mesh designed to cover $0.1 \mathrm{~m}^{2}$ of substrate. At each location, a composite QMH sample was collected by making four sweeps of equal effort in each of four locations. Although these samples were designated as "qualitative," using equal effort in collecting the samples resulted in an approximate relativeabundance measure that could be compared among locations (VTDEC, 2006).

Samples were preserved in 70-percent isopropyl alcohol and shipped to EcoAnalysts Inc., Moscow, ID, for taxonomic identifications and calculation of metrics of abundance, dominance, richness, composition, functional feeding groups, diversity/evenness, and biotic indices. A minimum of 300 individuals or 25 percent of the sample was counted and identified for each sample. The RTH data also were provided to VTDEC so that the agency could conduct a biological assessment of the data and determine the extent of impairment to the streams. 


\section{Fish Assemblage Data}

Fish assemblages were surveyed in the field following USGS protocols (Crawford and Luoma, 1993; Moulton and others, 2002). Fish were collected by electrofishing with a backpack unit along the $100-\mathrm{m}$ reach that was associated with each of the water-chemistry sampling location in Schoolhouse Brook (five locations) and the Ompompanoosuc River (three locations) (figs. 1 and 2). The fish surveys were conducted with the use of a single backpack unit in Schoolhouse Brook and with the use of two backpack units in the Ompompanoosuc River. ${ }^{1}$ Fish were weighed, measured, and released, except for those specimens used for tissue samples for analysis of trace element concentrations. These fish were whole-body samples that used single fish for brook trout and composites of five to eight fish for blacknose dace. Fish tissue samples were freeze-dried, water loss during drying was measured, and samples were analyzed for trace elements using ICP-MS and for mercury using continuous-flow cold-vapor atomic absorption spectrometry by the USGS Analytical Chemistry Services Group in Denver, CO.

\section{Toxicity Tests}

Toxicity tests have been performed on surface water, whole sediment, and sediment pore water at the Ely Mine site. Surface-water toxicity testing using the water flea Ceriodaphnia dubia and the fathead minnow Pimephales promelas were performed at the USEPA New England Regional Laboratory in North Chelmsford, MA, in 2006. Methods and results are described by TechLaw, Inc. (TechLaw, Inc., 2006b). Whole sediment samples and pore water samples were collected at 10 sampling locations in August 2006. The toxicity of whole sediments was evaluated using 28-day exposures with the amphipod Hyalella azteca and 10-day exposures with the midge Chironomus dilutus, with endpoints of survival for both species, length of amphipods, and ash-free dry weight (AFDW) of midges. Tests were conducted and evaluated by the USGS Columbia Environmental Research Center (CERC) in Columbia, MO, according to standard methods for conducting whole-sediment toxicity tests (USEPA, 2000; ASTM, 2007) (appendix 1). Amphipod and midge exposures were conducted in 300-milliliter $(\mathrm{mL})$ exposure chambers containing $100-\mathrm{mL}$ sediment and $175-\mathrm{mL}$ overlying water at $23 \pm 1{ }^{\circ} \mathrm{C}$. Tests with each of 11 Ely Mine sediments and one control sediment (a wetted soil from Florissant, MO) had 8 replicate chambers for each species, with 10 organisms in each chamber. Overlying water in test chambers was well water, diluted with deionized water to target hardness of $100 \mathrm{mg} / \mathrm{L}$

\footnotetext{
${ }^{1}$ The Ompompanoosuc River location below the confluence of Schoolhouse Brook (OR-23200M) was resurveyed in August 2007 with a single backpack unit. The number of fish originally captured at this location in 2006 was lower than expected, which could be attributed to effects from acid-rock drainage, limited habitat features, or collection bias. Resurveying the location helped determine if abundance was affected by acid-mine drainage contamination (for example, if low abundance both times) or sampling efficiency (for example, if abundance was significantly higher when resurveyed).
}

as $\mathrm{CaCO}_{3}$. Overlying water in test chambers was renewed by an automatic water delivery system to deliver two volume replacements per day. Water quality of overlying water was monitored biweekly.

The toxicity of pore water was evaluated by USEPA as described by TechLaw, Inc. (TechLaw, 2006a). Pore waters for toxicity testing were extracted from each of the sediment samples by centrifugation and filtration $(0.45 \mu \mathrm{m})$, and by in situ sampling. Aliquots of each sample were analyzed by the USGS Analytical Chemistry Services Group in Denver, $\mathrm{CO}$. The toxicity of in situ pore waters was evaluated using 96-hour exposures with the amphipod Hyalella azteca and with the midge Chironomus dilutus, with endpoints of survival for both species.

In addition, toxicity testing also was done by USEPA for the ponds along the tributary to Ely Brook to the northeast. These tests included survival of fathead minnows and the hatching efficiency of wood frog (Rana sylvatica) eggs and the survival of their tadpoles (TetraLaw, Inc., 2008).

As an additional measure of risk within the ponds, USEPA performed in situ amphibian embryo-larval toxicity testing in 2007 (TechLaw, Inc., 2008). For these tests, wood frog egg masses were collected from an offsite reference pond and placed within enclosures in Ely Mine ponds 1, 4, and 5.

\section{Quality-Control Procedures}

Field quality-control procedures for samples collected in August 2006 included the collection of blanks and replicates for surface- and pore-water samples and replicates for sediment samples. Quality-control data for all media are presented in appendixes in 2,3, and 4. Standard reference materials were submitted along with water and sediment samples. Field blanks provide information on bias or the potential for contamination of analytical results by sample collection, processing, and analysis (Spahr and Boulger, 1997). Concentrations of most constituents discussed in this report were below detection limits for the field-blank samples with the exception being zinc. Total zinc concentrations of 1.3 and 1.9 micrograms per liter $(\mu \mathrm{g} / \mathrm{L})$ were reported for surface- and pore-water fieldblank samples. Field-replicate samples provide information on the variability of results (Spahr and Boulger, 1997). The absolute difference between environmental and replicate water samples for constituent concentrations discussed in this report ranged from 0 to $11 \mu \mathrm{g} / \mathrm{L}$. Analytical laboratory qualitycontrol procedures are summarized in Taggart (2002).

\section{Data Analysis and Statistical Methods}

Selected results from data in Argue and others (2008) and from this study are presented in the following sections and are shown as a series of graphs and plots used to analyze the data. For samples where multiple analytical methods were used, preference was given to the method with the lower reporting limit.

Chronic criteria standards for the protection of aquatic biota were used to compare trace-element concentrations in 
water from data in Argue and others (2008) and from this study to water-quality guidelines and will be referred to as ambient water-quality criteria (AWQC). State of Vermont AWQC chronic criteria standards (VTAWQC) were used for analysis of $\mathrm{As}, \mathrm{Cd}, \mathrm{Cr}, \mathrm{Cu}, \mathrm{Fe}, \mathrm{Pb}, \mathrm{Hg}, \mathrm{Ni}, \mathrm{Se}, \mathrm{Ag}$, and $\mathrm{Zn}$ concentrations [Vermont Natural Resources Board (VTNRB), 2006]. The chronic toxicity standards for $\mathrm{Cd}, \mathrm{Cu}, \mathrm{Pb}, \mathrm{Ni}, \mathrm{Ag}$, and $\mathrm{Zn}$ were adjusted based on hardness according to the VTAWQC (VTNRB, 2006). Hardness values for samples in this report were calculated from concentrations of $\mathrm{Ca}$ and $\mathrm{Mg}$, in milliequivalents per liter (meq/L). The USEPA National Recommended Water Quality Criterion Continuous Concentration standard was used for analysis of total aluminum ( $\mathrm{Al})$ concentrations (USEPA, 2006). Tier II secondary chronic values summarized in Suter (1996) were used for analysis of dissolved concentrations of $\mathrm{Sb}, \mathrm{Ba}, \mathrm{Be}, \mathrm{Co}, \mathrm{Mn}, \mathrm{Sr}, \mathrm{Tl}, \mathrm{U}$, and V.

Consensus-based sediment quality guidelines developed by MacDonald and others (2000) were used to compare traceelement concentrations in stream sediment from this study to sediment-quality guidelines. The PEC was used for analysis of $\mathrm{Cd}, \mathrm{Cu}, \mathrm{Pb}, \mathrm{Ni}$, and $\mathrm{Zn}$ (MacDonald and others, 2000). Sediment toxicity is also assessed using the ESB (Di Toro and others, 2005; USEPA, 2005).

Water and sediment toxicity analysis was done using the hazard quotient (HQ) and hazard index (HI) methods (USEPA, 1986). The HQ is a ratio of the measured traceelement concentration to the chronic toxicity standard for that element. Trace elements with an HQ value greater than 1 have the potential to be toxic to aquatic communities. The HI is a sum of the HQ values for select constituents at each location and was used to describe the potential cumulative effect of contaminants on aquatic communities. Because of their concentrations in the water, and sediment, their inclusion in the simultaneously extractable metals fraction, and their toxicity to aquatic biota, $\mathrm{Cd}, \mathrm{Cu}, \mathrm{Pb}, \mathrm{Ni}$, and $\mathrm{Zn}$ were used to calculate $\mathrm{HI}$ in this report.

A statistical analysis of water data in Argue and others (2008) and analysis of instantaneous constituent loads from the August 2006 samples were conducted to investigate the origin and transport of potential contaminants at the Ely site. Summary statistics for surface-water data were analyzed by SAS/STAT software (version 9.1; SAS Institute, Inc., 1998) and robust regression on order statistics (ROS), which uses a probability plot of the logarithms of data to account for datasets that includes multiple detection limits (Helsel and Cohn, 1988; Helsel, 2005). The Kruskal-Wallis statistical test, a non-parametric analysis of variance (ANOVA) test that uses ranked data, was performed using SAS/STAT statistical software (SAS Institute, Inc., 1998) to determine if there were statistical differences among Ely Brook tributaries, Ely Brook, Schoolhouse Brook, the Ompompanoosuc River, and background conditions. The level of significance for ANOVA was set at alpha equal to 0.05 . If a significant difference was found, the Tukey's multiple-comparison test was used to determine which groups differed significantly (Helsel and Hirsch, 1992). Results of this analysis were examined among stream reaches and background locations by use of box plots. Results below the maximum detection limit used in each analysis were considered estimated, and box plots for these values were expressed as dashed lines (Helsel, 2005).

The RTH invertebrate and fish survey data were provided to the VTDEC Water Quality Division, which analyzed the data as specified in their bioassessment protocols for wadeable streams and rivers (VTDEC, 2004) to determine the extent of impairment to the locations. The assessment of the ecological condition of a location was based on how the invertebrate or fish assemblage scored among several metric categories that characterized assemblage structure and function. A fishassemblage assessment was indicated numerically from an index of biotic integrity (IBI), which was based on compiled scores of the individual structure and function metrics. Assessments based on RTH invertebrate assemblages did not rely on an IBI, but instead, each of eight metrics was scored against threshold values for pass, fail, or intermediate; the comprehensive assessment for each location is then based on a compilation of the eight qualitative scores. Depending how the invertebrate assemblage scored over the eight metrics, or how the fish assemblage scored with the IBI, the assessment was qualitatively summarized as poor, fair, good, very good, or excellent, which is pertinent to Vermont Class B water-quality standards. At the time of this study, VTDEC did not have an established protocol for assessing sites with DTH and QMH data.

Differences in fish assemblages among the locations were measured in two ways, both of which used the fish IBI to represent the assemblage condition at each location: The IBI scores were compared along the stream gradient (upstream to downstream) to determine where effects from acid-rock drainage likely occurred, the relative impairment across sites, and if there was a trend toward recovery; secondly, the IBI scores were compared against the $\mathrm{HI}$ values to characterize changes in condition along a contamination gradient. Differences in invertebrate assemblages also were measured over stream and contaminant gradients, but assemblage characterizations were not based on a common IBI because different types of samples were collected (RTH, DTH, QMH) and the VTDEC bioassessment procedure of a qualitative ranking only applied to the RTH samples. The assessment for the RTH samples did not derive a single IBI for direct comparison but used a qualitative ranking. Therefore, two of the eight metrics used in bioassessments by VTDEC were used to characterize biological condition of the sites: invertebrate abundance and richness (total number of individuals and total number of taxa, respectively). Values of these two metrics were determined for all of the invertebrate sample types (RTH, DTH, QMH) to serve as a common baseline for comparison of all locations. When comparing changes in fish and invertebrate assemblages across sites, reference baselines were the fish IBI scores and invertebrate abundance and richness values from the most upstream location in the respective system (EB-1080M, SB-3670M, Ely pond 1, OR-24050M).

Fish-tissue data were compared to the critical body residue of metals that were used to derive the $\mathrm{HI}$ for $\mathrm{Cd}, \mathrm{Cu}$, 
$\mathrm{Pb}, \mathrm{Ni}$, and $\mathrm{Zn}$, and additionally for $\mathrm{Hg}$. For a particular fish species, a critical body residue (CBR) is a literature-based benchmark that represents a metal concentration in the tissue at which adverse effects have been observed (effects level), or below which an adverse effect was not observed (no observable effects level). In this study, the critical body residues were based only on literature values for no-effect and effect levels in salmonids because brook trout (a salmonid) is a species of special interest in the waterways affected by the Ely Mine, and also because no relevant data were found for blacknose dace or any other cold-water cyprinid. The salmonid critical body residue values were compared to metal concentrations in the samples of single brook trout. However, brook trout were only captured at three sites (SB-3670M, SB-3100M, OR$23200 \mathrm{M}$ ), whereas blacknose dace were captured at all eight fish-survey sites. Thus, the brook trout critical body residue values were also compared to those for the composite samples of blacknose dace to provide a more comprehensive view of the study area.

Toxicity data were analyzed by SAS/STAT software (version 9.1). Toxicity data were transformed to ranks before ANOVA testing. Overall ANOVA tests were conducted to determine whether test endpoints differed significantly among all sediments tested $($ rho $<0.05)$. For endpoints with significant overall ANOVA tests, separate ANOVA tests were conducted with sediments from each of the three streams (Ely Brook, Schoolhouse Brook, and the Ompompanoosuc River) with the one-tailed Dunnett's test used to determine which responses were significantly less than those in reference sediments from each stream.

\section{Description of Study Area}

\section{Mine Site}

The Ely Mine site is located within the Vermont copper belt in Vershire, Orange County, VT; it is approximately 1,800 acres (730 ha) in size, and contains piles of waste rock, ore waste, tailings, and smelter waste. Waste-rock and tailings piles extend from an area downgradient of the main shaft to the center of the site, whereas ore and smelter wastes are located near the southern boundary (fig. 2).

Surface waters at the mine site drain primarily to Ely Brook. Ely Brook originates upgradient and northwest of the mine site, generally flows north to south, and is west of the mine workings and waste piles (fig. 2). A short tributary to Ely Brook originates northeast of the mine site and flows through a series of small ponds before crossing waste-rock piles and joining the main stem of Ely Brook. Waters from Ely Brook flow into Schoolhouse Brook which, in turn, flows for approximately 3,270 meters to the confluence with the Ompompanoosuc River (figs. 1 and 2).

The predominant land use of the study area is forest, and approximately 37 percent of the Ompompanoosuc River basin above the confluence with the West Branch is mixed forest (table 2) (Olson and others, 2005). However, in the Ely Brook basin, the percentage of mixed forest decreases to less that 20 percent. Locally, the mean annual temperature is $5.6{ }^{\circ} \mathrm{C}$, mean summer temperature is $15^{\circ} \mathrm{C}$, and mean annual precipitation varies with altitude and ranges from 91 to $102 \mathrm{~cm}$ (table 2) (Olson and others, 2005).

\section{Ely Brook}

Ely Brook has a total drainage area of $1.11 \mathrm{~km}^{2}$, stream reach of approximately $1,500 \mathrm{~m}$, and a range in altitude from approximately 296 to $383 \mathrm{~m}$. The surficial geology of the basin is predominantly till (fig. 3). A qualitative geomorphic characterization of a stream segment from river meter 0 to 1,080 found the distribution of geomorphic channel units to be approximately 45 percent riffle, 42 percent run, and 13 percent pool. Two distinct patterns in the geomorphology were also present: the channel above river meter 440 was dominated by boulder and woody debris riffles and had an average channel slope of 11 percent, whereas the channel below river meter 440 was dominated by gravel riffles and sand runs and had an average channel slope of 1.5 percent. Channel slope for $100-\mathrm{m}$ reaches at each of the sampling locations ranged from 1.8 percent to 14.6 percent (table 2). Ely Brook is categorized as a small high-gradient stream by the State of Vermont, based on the stream classifications that are used in the bioassessment protocols developed for fish and invertebrate assemblages in Vermont (VTDEC, 2004).

Four tributaries flow into Ely Brook from the east, come in contact with mine wastes, and have the potential to discharge trace elements and acidity to Ely Brook. Ely Brook tributary 1, which may be intermittent, discharges to Ely Brook at river meter 350 and is downgradient from ore waste and roasting beds. Ely Brook tributary 2 drains a series of ponds located in the northeast section of the site, flows over a waste-rock pile in the center of the site, and discharges to Ely Brook at river meter 540. Ely Brook tributary 2 was referred to as East Branch Ely Brook by Cherau and others (2005). Ely Brook tributary 3 originates downgradient of the main shaft, flows north to south over waste rock piles, and discharges to Ely Brook tributary 2 at river meter 10. Ely Brook tributary 4, which may be intermittent, originates downgradient of mine shaft 4 and discharges to Ely Brook at river meter 800 . In addition, tributary 2 has a small tributary, tributary 5 , that drains a small area to the east of tributary 2 and has been sampled by various studies.

A series of six ponds drain the eastern slope of the Ely Brook basin and form the headwaters for Ely Brook tributary 2 (fig. 2). The ponds range in size from approximately $35 \mathrm{~m}^{2}$ (pond 6) to $3,800 \mathrm{~m}^{2}$ (pond 1) and are located at Ely Brook tributary 2 river meter 195 (pond 6), 290 (pond 5), 320 (pond 4), 345 (pond 3), 385 (pond 2), and 432 (pond 1). Pond 1, contained behind an earthen dam, is believed to have been a water-supply reservoir constructed some time between 1882 and 1899 (Cherau and others, 2005). The pond is fed 
Table 2. Select basin and reach characteristics for sampling locations at the Ely Mine study area, Vershire, VT.

$\left[\mathrm{km}^{2}\right.$, square kilometer; $\mathrm{m}$, meter; $\mathrm{cm}$, centimeter; \%, percent; ${ }^{\circ} \mathrm{C}$, degrees Celsius; SHG, small high gradient; CWIBI, coldwater index of biotic integrity; MHG, medium-size high gradient; MWIBI, mixed water index of biotic integrity]

\begin{tabular}{|c|c|c|c|c|c|c|}
\hline \multirow[t]{2}{*}{ Characteristic } & \multicolumn{5}{|c|}{$\begin{array}{c}\text { Ely Brook } \\
\text { (River meter) }\end{array}$} & \\
\hline & $\mathbf{O}^{\mathrm{a}}$ & 90 & 600 & 770 & 1,080 & \\
\hline \multicolumn{7}{|l|}{ Basin } \\
\hline Drainage area $\left(\mathrm{km}^{2}\right)$ & 1.11 & 1.06 & 0.44 & 0.36 & 0.22 & \\
\hline Elevation $(\mathrm{m})$ & & 297 & 313 & 329 & 370 & \\
\hline Lakes/Ponds (\%) & .13 & .13 & .00 & .00 & .00 & \\
\hline Annual precipitation $(\mathrm{cm})$ & 97.8 & & & & & \\
\hline Coniferous forest $(\%)$ & 1 & & & & & \\
\hline Mixed forest $(\%)$ & 17 & & & & & \\
\hline Mean temperature $\left({ }^{\circ} \mathrm{C}\right)$ & 5.6 & & & & & \\
\hline Mean summer temperature $\left({ }^{\circ} \mathrm{C}\right)$ & 15.0 & & & & & \\
\hline Strahler stream order & 1 & 1 & 1 & 1 & 1 & \\
\hline \multicolumn{7}{|l|}{ Reach } \\
\hline Canopy (\%) & & 100 & 100 & 100 & 100 & \\
\hline Channel slope & & .018 & .095 & .130 & .146 & \\
\hline Riffle $(\%)$ & 45 & 69 & 36 & 42 & 94 & \\
\hline Run $(\%)$ & 42 & & 41 & 58 & 6 & \\
\hline Pool (\%) & 13 & 31 & 23 & & & \\
\hline \multirow[t]{3}{*}{ VT Macroinvertebrate Category } & SHG & SHG & SHG & SHG & SHG & \\
\hline & \multicolumn{6}{|c|}{$\begin{array}{c}\text { Schoolhouse Brook } \\
\text { (River meter) }\end{array}$} \\
\hline & $\mathbf{O}^{\mathrm{a}}$ & 140 & 1,360 & 2,400 & 3,125 & 3,670 \\
\hline \multicolumn{7}{|l|}{ Basin } \\
\hline Drainage area $\left(\mathrm{km}^{2}\right)$ & 25.2 & 25.2 & 24.7 & 19.4 & 15.6 & 14.2 \\
\hline Elevation $(\mathrm{m})$ & & 212 & 238 & 273 & 291 & 305 \\
\hline Lakes/Ponds (\%) & .04 & .04 & .04 & .05 & .06 & .05 \\
\hline Annual precipitation $(\mathrm{cm})$ & 101 & & & & & \\
\hline Coniferous forest $(\%)$ & 8 & & & & & \\
\hline Mixed forest (\%) & 28 & & & & & \\
\hline Mean temperature $\left({ }^{\circ} \mathrm{C}\right)$ & 5.4 & & & & & \\
\hline Mean summer temperature $\left({ }^{\circ} \mathrm{C}\right)$ & 14.8 & & & & & \\
\hline Strahler stream order & 2 & 2 & 2 & 2 & 2 & 2 \\
\hline \multicolumn{7}{|l|}{ Reach } \\
\hline Canopy (\%) & & 25 & 25 & 50 & 20 & 10 \\
\hline Channel slope & & .005 & .025 & .024 & .028 & .030 \\
\hline Riffle (\%) & 95 & 69 & 94 & 77 & 100 & 82 \\
\hline Run $(\%)$ & 3 & & & & & \\
\hline Pool (\%) & 2 & 31 & 6 & 23 & & 18 \\
\hline VT Macroinvertebrate Category & SHG & SHG & SHG & SHG & SHG & SHG \\
\hline \multirow[t]{3}{*}{ VT Index of Biotic Integrity } & CWIBI & CWIBI & CWIBI & CWIBI & CWIBI & CWIBI \\
\hline & \multicolumn{4}{|c|}{$\begin{array}{c}\text { Ompompanoosuc River } \\
\text { (River meter) }\end{array}$} & & \\
\hline & $8,350^{\mathrm{a}}$ & 23,200 & 23,630 & 24,050 & & \\
\hline \multicolumn{7}{|l|}{ Basin } \\
\hline Drainage area $\left(\mathrm{km}^{2}\right)$ & 168 & 51.0 & 76.9 & 77.4 & & \\
\hline Elevation (m) & & 240 & 242 & 243 & & \\
\hline Lakes/Ponds (\%) & 1.41 & .09 & .09 & .11 & & \\
\hline Annual precipitation $(\mathrm{cm})$ & 93.7 & 101 & & & & \\
\hline Coniferous forest (\%) & 16 & 8 & & & & \\
\hline Mixed forest $(\%)$ & 37 & 29 & & & & \\
\hline Mean temperature $\left({ }^{\circ} \mathrm{C}\right)$ & 5.7 & 5.3 & & & & \\
\hline Mean summer temperature $\left({ }^{\circ} \mathrm{C}\right)$ & 15.2 & 14.7 & & & & \\
\hline Strahler stream order & 4 & 3 & 3 & 2 & & \\
\hline \multicolumn{7}{|l|}{ Reach } \\
\hline Canopy (\%) & & 50 & 25 & 40 & & \\
\hline Channel slope & & .005 & .005 & .005 & & \\
\hline Riffle $(\%)$ & 39 & 39 & 60 & 89 & & \\
\hline Run $(\%)$ & 51 & 36 & 40 & & & \\
\hline Pool (\%) & 11 & 25 & & 11 & & \\
\hline VT Macroinvertebrate Category & MHG & MHG & MHG & MHG & & \\
\hline VT Index of Biotic Integrity & MWIBI & MWIBI & MWIBI & MWIBI & & \\
\hline
\end{tabular}

${ }^{a}$ Reach characteristics are a summary of results from a habitat assessment conducted in June 2006 (appendix 1). 


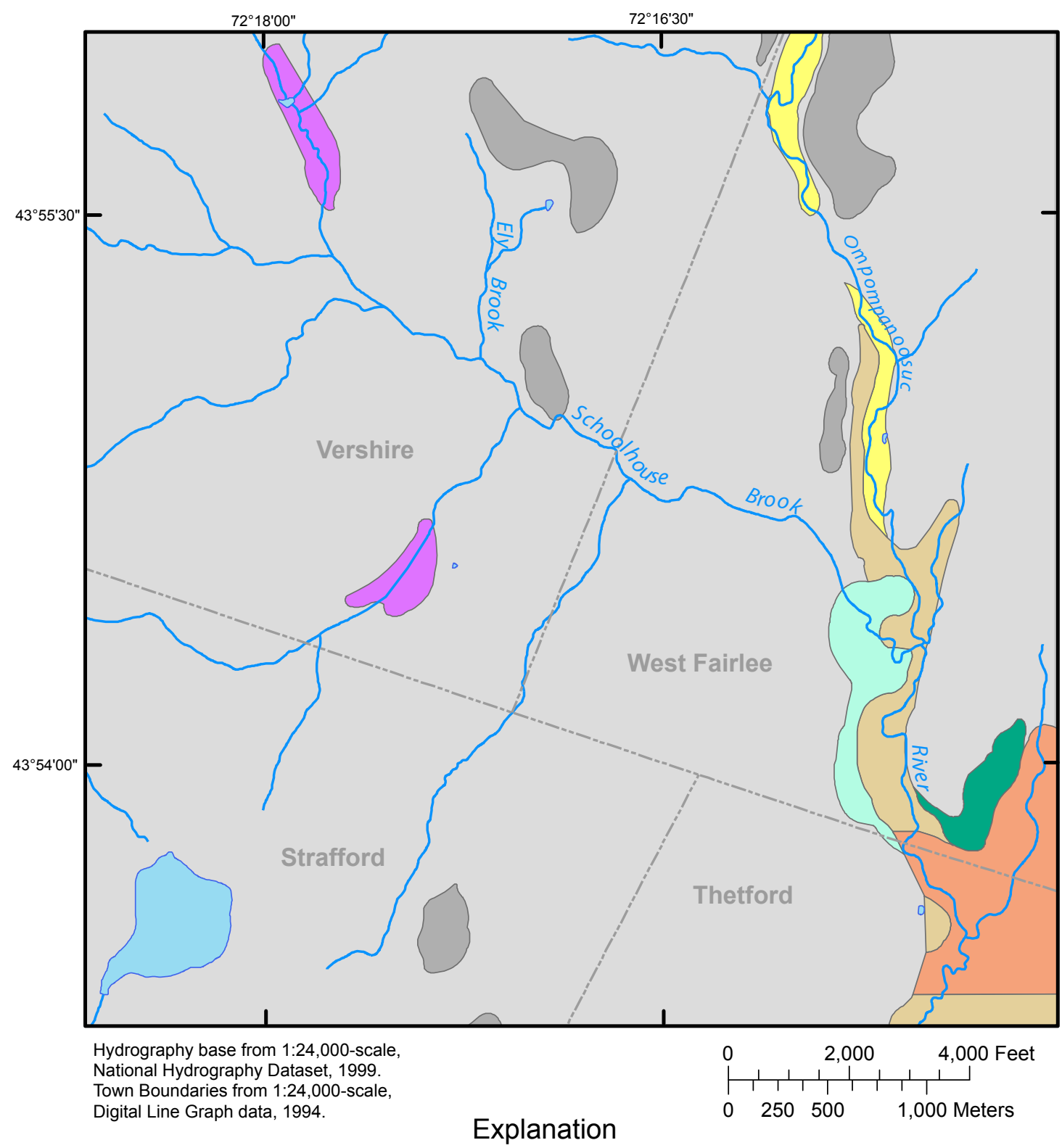

\section{Surficial Geology}

\begin{tabular}{|c|c|c|}
\hline Bedrock & Pebbly Sand & Lake \\
\hline Beach Gravel & Recent Alluvium & Stream / River \\
\hline Delta Gravel & Swamp Peat & \\
\hline Lake sand & Till & \\
\hline
\end{tabular}

Figure 3. The surficial geology of the Ely Mine Superfund site study area, VT. 
by an intermittent stream that drains from the east and possibly by a spring (Cherau and others, 2005). Ponds 2 through 5 appear to be the result of beaver dams created along Ely Brook tributary 2. Pond 6, however, is a depression formed in a short exploration shaft, or other type of abandoned minedevelopment excavation. Two small, intermittent streams drain into the pond system below pond 1: one stream flows into pond 2 from the northeast, and one stream flows adjacent to a waste-rock pile and into pond 5 from the north. A groundwater seep also is present upgradient of pond 4.

\section{Schoolhouse Brook}

Schoolhouse Brook has a total drainage area of $25.2 \mathrm{~km}^{2}$, stream reach of approximately $7,650 \mathrm{~m}$, and a range in altitude from approximately 210 to $480 \mathrm{~m}$. Two tributaries flow into Schoolhouse Brook below the confluence with Ely Brook, at approximately river meter 2,100 and river meter 2,915 . The contributing drainage area for these tributaries is $7.1 \mathrm{~km}^{2}$.

The surficial geology of the basin is predominantly till (fig. 3). However, the surficial geology underlying the stream channel from river meter 0 to 600 is characterized as being delta gravel and lake sand. A qualitative geomorphic characterization of the stream segment from river meter 0 to 3,670 found the distribution of geomorphic channel units to be approximately 95 percent riffle, 3 percent run, and 2 percent pool. The average slope for this stream segment is 2.6 percent. Below river meter 600 , however, the distribution of riffle, run, and pool environments becomes more sequential as the channel slope decreases to approximately 1 percent. Channel slope for $100-\mathrm{m}$ reaches at each of the sampling locations ranged from 0.5 to 3.0 percent (table 2). Schoolhouse Brook is categorized as a small high-gradient stream, which is characteristic of a stream that could support a cold-water fishery (VTDEC, 2004). Therefore, when assessing the condition of fish assemblages, in Schoolhouse Brook, an IBI designed for coldwater fish (CWIBI) was used to indicate the relative degree of impairment to the assemblages.

\section{Ompompanoosuc River}

The Ompompanoosuc River above the confluence with the West Branch of the Ompompanoosuc River has a total drainage area of $168 \mathrm{~km}^{2}$. The surficial geology of the basin is predominantly till (fig. 3). However, the surficial geology underlying the stream channel in the study area is characterized as delta gravel, lake sand, and pebbly sand. A qualitative geomorphic characterization of a stream segment from river meter 20,300 to 24,200 found the distribution of geomorphic channel units to be approximately 39 percent riffle, 51 percent run, and 10 percent pool. The average slope for this stream segment is 0.5 percent. Two distinct patterns in the geomorphology were present: the channel above river meter 23,640 was dominated by boulder and cobble riffles and had an average channel slope of 0.5 percent, whereas the channel below river meter 23,640 was dominated by gravel riffles and sand runs and had an average channel slope of 0.2 percent. Channel slope for $100-\mathrm{m}$ reaches at each of the sampling locations was 0.5 percent (table 2). The Ompompanoosuc River is categorized as a medium high-gradient stream with a mixed water fishery; therefore, a mixed water IBI (MWIBI) was used to indicate the relative degree of impairment to the fish assemblages (VTDEC, 2004).

\section{Nature and Extent of Contamination}

Acid-mine drainage occurs when sulfide-bearing waste rock and tailings come in contact with waters containing dissolved oxygen. The resulting oxidation reactions release associated metals and acidity, which may impact the biological community and significantly lower the $\mathrm{pH}$ of downstream waterways. Released metals that are transported downstream may be removed from solution through precipitation of and sorption onto iron and manganese hydroxides (Harvey and Fuller, 1998; Tonkin and others, 2004). Attenuation of metals also has been attributed to precipitation and sorption within the hyporheic zone as contaminated waters infiltrate and mix with shallow groundwater (Harvey and Fuller, 1998; Fuller and Harvey, 2000).

Waste rock and tailings at the Ely Mine site have similar mineralogy and chemistry and leach comparable metal concentrations and acidity to those observed at the Elizabeth and Pike Hill mines (Seal and others, 2001; Piatak and others, 2004, 2006). The weathering of mine wastes in the Vermont copper belt has been shown to produce concentrations of metals in downstream waterways greater than those allowed by USEPA acute and chronic standards (Holmes and others, 2002; Kiah and others, 2007).

Surface-water samples have been collected at 103 stream and 21 seep locations in the study area (table 1) (Argue and others, 2008). Concentrations greater than AWQC were observed for 15 elements: $\mathrm{Al}, \mathrm{Ba}, \mathrm{Cd}, \mathrm{Cr}, \mathrm{Co}, \mathrm{Cu}, \mathrm{Fe}, \mathrm{Pb}, \mathrm{Mn}$, $\mathrm{Hg}, \mathrm{Ni}, \mathrm{Se}, \mathrm{Ag}, \mathrm{U}$, and $\mathrm{Zn}$ (appendix 5). These results are similar to those of Piatak and others (2004), who showed the bulk geochemistry of Ely Mine waste comprised $\mathrm{Fe}>\mathrm{Al}>\mathrm{S}$ $>\mathrm{K}>\mathrm{Ca}$, and trace elements comprised $\mathrm{Cu}>\mathrm{Mn}>\mathrm{Ba} \approx \mathrm{U} \approx$ $\mathrm{Zn}>\mathrm{Cr}>\mathrm{Sr}>\mathrm{Co} \approx \mathrm{Mo} \approx \mathrm{Pb}$, on a mass basis. Leach tests performed on the mine waste also found $\mathrm{Cd}, \mathrm{Co}, \mathrm{Cu}, \mathrm{Ni}$, and $\mathrm{Zn}$ to be the dominant elements released (Piatak and others, 2004).

Surface-water data were compared to regional streamflow characteristics computed for the Ompompanoosuc River at Union Village, VT (USGS station 01141500) to investigate the distribution of water samples relative to expected streamflows in the basin. A cumulative frequency duration curve showing the percentage of time that a given daily mean streamflow is expected to be equaled or exceeded at USGS station 01141500 and the distribution of water samples in each stream reach, relative to the various daily mean streamflows observed at station 01141500, are shown in figure 4. Based on 


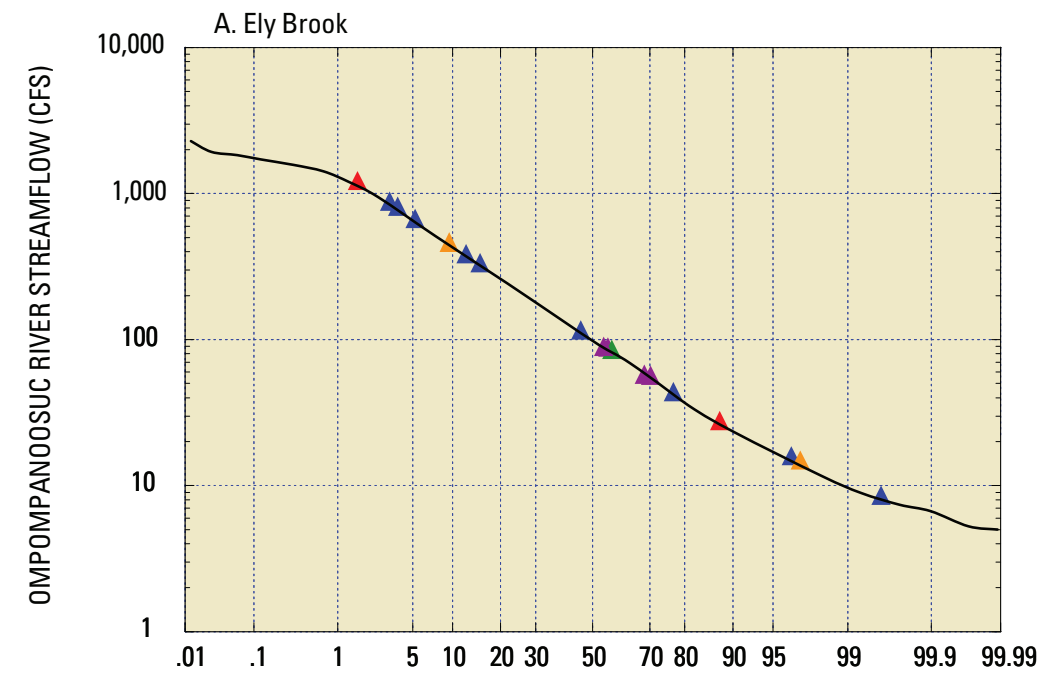

B. Schoolhouse Brook
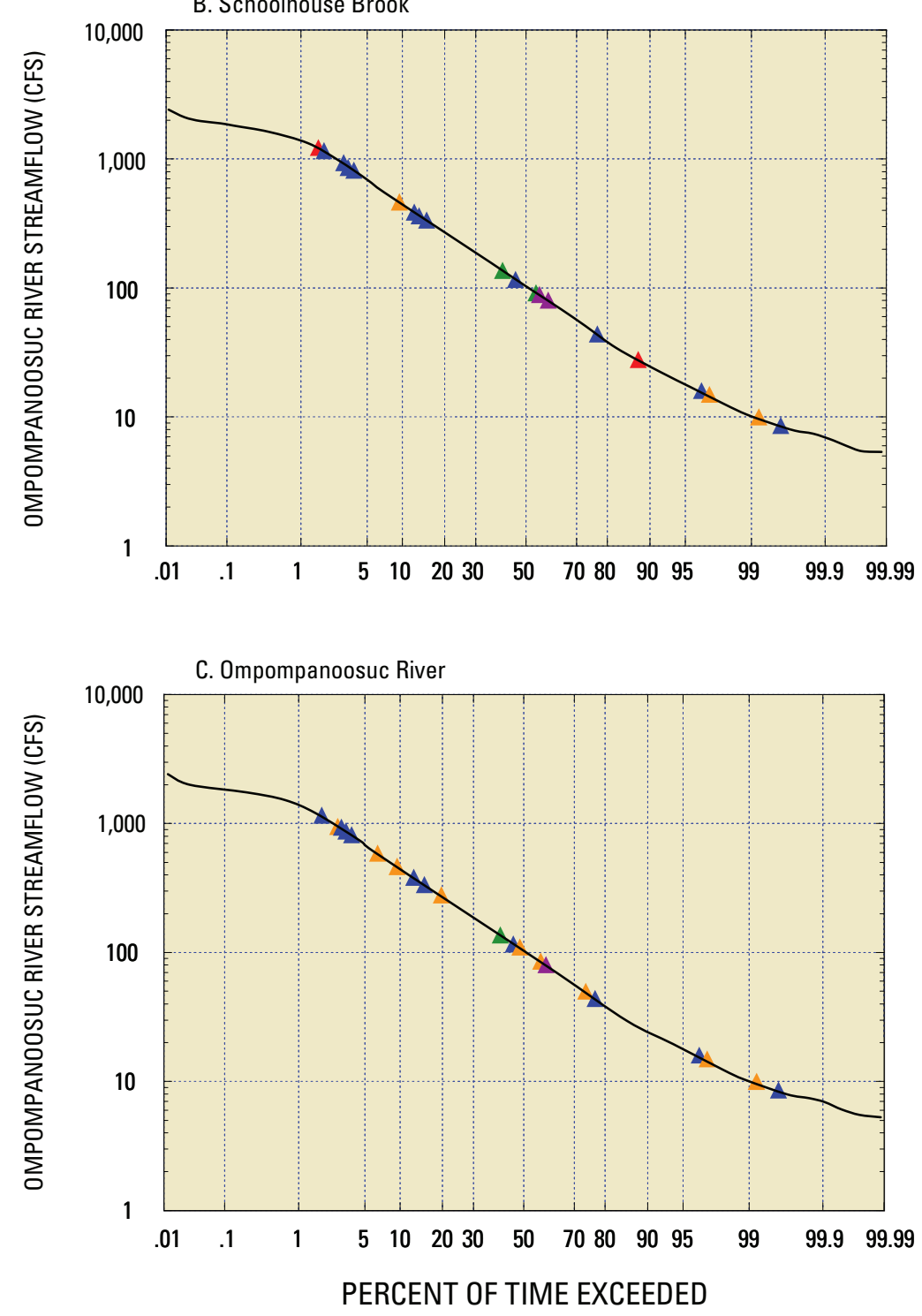

\section{EXPLANATION}

Water-quality Year sampled: Agency sample

\begin{tabular}{ll}
$\Delta$ & 2000-01: Arthur D. Little, Inc \\
$\Delta$ & 2002: USACE and USGS \\
$\Delta$ & 2004: URS Company \\
$\Delta \quad$ & 2006: USGS \\
\hline & Flow-duration curve
\end{tabular}

Figure 4. Flow-duration curve for U.S. Geological Survey gaging station 01141500 Ompompanoosuc River at Union Village Dam, VT, with streamflow distribution of water-quality samples collected in (A) Ely Brook, (B) Schoolhouse Brook, and (C) the Ompompanoosuc River. Flow-duration curve was based on daily mean streamflows for period 1949-89. Water-quality samples reflect days that data were collected and not individual samples. CFS, cubic feet per second. 
this analysis, surface-water samples were well distributed over the expected range in streamflows, as greater than 95 percent of the streamflows that may be expected at the site were represented by a water sample (fig. 4). Furthermore, 95 percent of the streamflows associated with the samples were within 2 standard deviations of the mean, and the median probability of exceedence for the dataset was 52 percent, indicating an equal distribution of water samples across expected streamflows. Water samples collected in August 2006 ranged from a probability of exceedence of about 40 percent on August 21 to about 55 percent on August 23 as samples were collected over the course of a recession in streamflow.

Surface water, pore water, sediment, invertebrates, and fish were sampled to define potential areas of impact from acid-mine drainage, to assess the ability of the streams to attenuate contaminants, and to identify the fraction of contaminants that may be bioavailable. Surface water and invertebrates were sampled at 12 stream sites in August 2006 and 6 pond sites in September 2006 (figs. 1 and 2, table 1). Pore water and sediment were sampled at 10 stream sites in August 2006. Fish were sampled at eight stream sites in September 2006 (table 3). Physical parameters for surfaceand pore-water samples are listed in tables 4 and 5 .

A preliminary analysis was conducted to determine if the biological assemblages (RTH, DTH, QMH invertebrates, and fish) were more strongly correlated to values of metal concentrations from surface water, pore water, or sediment. This analysis was not especially relevant for the Ompompanoosuc River locations because pore-water and sediment samples were collected at only two sites (that is, $\mid$ rho $\mid=1$ ). However, the results for Ely Brook, Schoolhouse Brook, and the Ely ponds indicated that the metal concentrations in the surfacewater samples were most strongly correlated with the QMH, $\mathrm{RTH}$, and fish samples, and metal concentrations in the porewater samples were most strongly correlated with the DTH samples. These results are exemplified in the Spearman rho values from correlations of in situ pore water, surface water, and sediment-metal concentrations with the total richness for invertebrates and the IBI score for fish (table 3). Based on these results, the analyses of biological data below relate a particular biological assemblage with the metal concentrations in the sample that is most directly associated with the assemblage (RTH, QMH, fish with surface-water metals; DTH with pore-water metals).

\section{Background Conditions}

\section{Surface-Water Geochemistry}

Sites in the study that are considered to represent background conditions with respect to historical mining are those water-quality sites upstream from any known mining disturbance. These sites include EB-1080M for Ely Brook, pond 1 for the northeastern tributary 2 to Ely Brook, SB-3670M for Schoolhouse Brook, and OR-24050M for the Ompompanoosuc River. Data from these sites from this study will be used as a basis for comparison with results from previous studies to gain insights into longer term variability of background water quality. Field parameters and chemical constituents for surface-water samples are summarized in table 4, and complete analyses are reported in appendix 6.

\section{Field Parameters and Major Inorganic Constituents}

The gross chemical properties of the background water samples vary according to the size of the catchment area. Previous reports found similar results (Seal and others, 2001; Holmes and others, 2002; Argue and others, 2008). The headwaters of Ely Brook (EB-1080M and pond 1) in the vicinity of the mine have lower $\mathrm{pH}$ and specific conductance values than the receiving streams, Schoolhouse Brook (SB-3670M) and the Ompompanoosuc River (OR-24050M). The $\mathrm{pH}$ of the

Table 3. Spearman rho values from correlating metal concentrations measured in surface water (SW), in situ pore water (PW), and sediment (SED) against invertebrate richness (RTH, QMH, and DTH samples) and against the index of biotic integrity scores for the fish surveys. The RTH, $\mathrm{QMH}$, and fish data were more strongly correlated to metals in SW (bold rho values) than to PW or SED. The DTH data were more strongly correlated to metals in PW (bold rho values) than to those in SW.

[RTH, riffle-targeted habitat; QMH, qualitative multi-habitat; DTH, depositional-targeted habitat; - - no value]

\begin{tabular}{|c|c|c|c|c|c|c|c|c|c|}
\hline \multirow{3}{*}{ Sample type } & \multicolumn{9}{|c|}{ Spearman rho value } \\
\hline & \multicolumn{3}{|c|}{ Ely Brook } & \multicolumn{3}{|c|}{ Schoolhouse Brook } & \multicolumn{3}{|c|}{ Ely Ponds } \\
\hline & sw & PW & SED & sw & PW & SED & sw & PW & SED \\
\hline $\begin{array}{l}\text { RTH (streams) or } \\
\text { QMH (ponds) }\end{array}$ & -1.000 & -0.800 & -0.800 & -0.821 & -0.632 & -0.200 & -0.886 & - & -0.657 \\
\hline DTH & -0.634 & -0.949 & -0.949 & -0.316 & -0.949 & -0.400 & - & - & - \\
\hline FISH & - & - & - & -0.764 & -0.632 & -0.200 & - & - & - \\
\hline Number of samples & 4 & 4 & 4 & 5 & 4 & 4 & 6 & - & 6 \\
\hline
\end{tabular}


Table 4. Constituents in filtered surface waters collected in August and September 2006 from the Ely Mine study area, Vershire, VT.

[The concentrations of the following elements were below their detection limits (given in parentheses in micrograms per liter, $\mu \mathrm{g} / \mathrm{L})$ : $\mathrm{Ag}(<3), \mathrm{As}(<1), \mathrm{Hg}(<5)$, Mo $(<2)$, Se $(<1), \mathrm{Tl}(<0.1)$, and V $(<0.5)$. S.C., specific conductance; DOC, dissolved organic carbon; $\mu \mathrm{S} / \mathrm{cm}$, microsiemens per centimeter; mg/L, milligrams per liter; $\mu \mathrm{g} / \mathrm{L}$, micrograms per liter; —, not determined; $<$, analyte not detected at the reporting level]

\begin{tabular}{|c|c|c|c|c|c|c|c|c|c|c|c|c|c|c|c|}
\hline $\begin{array}{c}\text { Stream and } \\
\text { location }\end{array}$ & $\mathrm{pH}$ & $\begin{array}{c}\text { S.C. } \\
(\mu S / \mathrm{cm})\end{array}$ & $\begin{array}{c}\text { Alkalinity } \\
\text { (mg/L as } \\
\mathrm{CaCO}_{3} \text { ) }\end{array}$ & $\begin{array}{c}\text { DOC } \\
\text { (mg/L) }\end{array}$ & $\underset{(\mathrm{mg} / \mathrm{L})}{\mathbf{N}}$ & $\begin{array}{c}P \\
(\mathrm{mg} / \mathrm{L})\end{array}$ & $\begin{array}{c}\mathrm{Ca} \\
(\mathrm{mg} / \mathrm{L})\end{array}$ & $\begin{array}{c}\mathrm{Fe} \\
(\mu \mathrm{g} / \mathrm{L})\end{array}$ & $\begin{array}{c}\mathrm{K} \\
(\mathrm{mg} / \mathrm{L})\end{array}$ & $\underset{(\mathrm{mg} / \mathrm{L})}{\mathrm{Mg}}$ & $\begin{array}{c}\mathrm{Na} \\
\text { (mg/L) }\end{array}$ & $\begin{array}{c}\mathrm{SiO}_{2} \\
(\mathrm{mg} / \mathrm{L})\end{array}$ & $\underset{(\mu \mathrm{g} / \mathrm{L})}{\mathrm{Al}}$ & $\begin{array}{c}B a \\
(\mu g / L)\end{array}$ & $\begin{array}{c}B e \\
(\mu g / L)\end{array}$ \\
\hline \multicolumn{16}{|l|}{ Ely Brook } \\
\hline EB-1080M & 7.2 & 87 & 41 & 1.9 & 0.07 & $0.003 \mathrm{E}^{\mathrm{a}}$ & 13.4 & 22 & 1.69 & 1.18 & 1.12 & 9.1 & 3.4 & 18.4 & $<0.05$ \\
\hline EB-770M & 6.3 & 149 & 11 & 0.8 & $0.04 \mathrm{E}$ & $0.002 \mathrm{E}$ & 17.2 & $<20$ & 2.43 & 3.2 & 1.64 & 17.2 & 25.1 & 19.9 & 0.06 \\
\hline EB-600M & 7.0 & 123 & 16 & 0.9 & $0.05 \mathrm{E}$ & $<0.004$ & 14.9 & $<20$ & 2.17 & 2.43 & 1.44 & 13.7 & 20.7 & 17 & $<0.05$ \\
\hline EM-POND1 & 7.0 & 51 & 19 & 3.5 & 0.46 & 0.036 & 5.77 & 66 & 1.67 & 1.07 & 1.2 & 2.2 & 15.8 & 9.61 & $<0.05$ \\
\hline EM-POND2 & 6.5 & 65 & 27 & 2.6 & 0.22 & 0.011 & 7.67 & 353 & 1.78 & 1.11 & 1.34 & 4.6 & 6.5 & 13.5 & $<0.05$ \\
\hline EM-POND3 & 6.7 & 70 & 31 & 2.6 & 0.25 & 0.006 & 8.72 & 253 & 1.75 & 1.17 & 1.3 & 5.1 & 6.2 & 12.5 & $<0.05$ \\
\hline EM-POND4 & 6.7 & 78 & 30 & 2.2 & 0.19 & 0.007 & 9.7 & 105 & 1.86 & 1.37 & 1.32 & 5.5 & 5.5 & 18.6 & $<0.05$ \\
\hline EM-POND5 & 6.5 & 117 & 17 & 1.4 & 0.11 & $0.003 \mathrm{E}$ & 13 & $<20$ & 2.13 & 2.44 & 1.41 & 9.2 & 10.1 & 13.7 & $<0.05$ \\
\hline SB-3125M & 7.8 & 215 & 89 & 1.3 & 0.11 & 0.005 & 35.1 & 49 & 2.34 & 1.99 & 4.16 & 8.9 & 124 & 19.8 & $<0.05$ \\
\hline SB-2400M & 8.3 & 210 & 89 & 1.2 & 0.09 & $0.003 \mathrm{E}$ & 35.8 & $<20$ & 2.42 & 2.03 & 4.62 & 9.1 & 128 & 18.5 & $<0.05$ \\
\hline SB-1360M & 7.9 & 203 & 86 & 1.5 & 0.09 & $0.003 \mathrm{E}$ & 33.8 & 13 & 2.29 & 1.95 & 4.27 & 8.6 & 84.4 & 18.4 & $<0.05$ \\
\hline SB-140M & 8.2 & 186 & 80 & 2 & 0.12 & 0.006 & 30.7 & 20 & 2.2 & 1.82 & 3.77 & 8.5 & 93.5 & 14.8 & $<0.05$ \\
\hline \multicolumn{16}{|c|}{ Ompompanoosuc River } \\
\hline OR-24050M & 8.0 & 196 & 88 & 2.5 & 0.21 & 0.007 & 32 & $<20$ & 2.16 & 1.46 & 5.22 & 7.2 & 13.4 & 19.9 & $<0.05$ \\
\hline OR-23630M & 8.0 & 198 & 87 & 2.6 & 0.2 & 0.006 & 32.9 & $<20$ & 2.23 & 1.55 & 5.45 & 7.6 & 23.3 & 20.2 & $<0.05$ \\
\hline OR-23200M & 8.1 & 196 & 85 & 2.6 & 0.2 & 0.005 & 32.6 & $<20$ & 2.24 & 1.61 & 5.15 & 7.8 & 44.6 & 19.1 & $<0.05$ \\
\hline
\end{tabular}

\begin{tabular}{|c|c|c|c|c|c|c|c|c|c|c|c|c|c|}
\hline $\begin{array}{c}\text { Stream and } \\
\text { location }\end{array}$ & $\begin{array}{c}\text { Cd } \\
(\mu g / L)\end{array}$ & $\begin{array}{c}\text { Co } \\
(\mu g / L)\end{array}$ & $\begin{array}{c}\mathrm{Cr} \\
(\mu \mathrm{g} / \mathrm{L})\end{array}$ & $\begin{array}{c}\mathrm{Cu} \\
(\mu \mathrm{g} / \mathrm{L})\end{array}$ & $\underset{(\mu g / L)}{M n}$ & $\underset{(\mu \mathrm{g} / \mathrm{L})}{\mathrm{Ni}}$ & $\begin{array}{c}\mathrm{Pb} \\
(\mu \mathrm{g} / \mathrm{L})\end{array}$ & $\begin{array}{c}S b \\
(\mu g / L)\end{array}$ & $\begin{array}{c}S r \\
(\mu g / L)\end{array}$ & $\underset{(\mu g / L)}{U}$ & $\begin{array}{c}\mathrm{Zn} \\
(\mu \mathrm{g} / \mathrm{L})\end{array}$ & $\begin{array}{c}\mathrm{NO}_{3} \\
(\mathrm{mg} / \mathrm{L})\end{array}$ & $\begin{array}{c}\mathrm{SO}_{4} \\
(\mathrm{mg} / \mathrm{L})\end{array}$ \\
\hline \multicolumn{14}{|l|}{ Ely Brook } \\
\hline EB-1080M & $<0.02$ & 0.08 & $<1$ & 1.3 & 124 & 0.5 & $<0.05$ & $<0.3$ & 47.6 & $<0.1$ & 5.6 & $<.08$ & 4.3 \\
\hline EB-770M & 0.95 & 31.1 & $<1$ & 837 & 217 & 12.1 & 0.1 & $<0.3$ & 62.3 & $<0.1$ & 114 & 0.5 & 52 \\
\hline EB-600M & 0.48 & 12.5 & $<1$ & 211 & 92.8 & 6.4 & 0.06 & $<0.3$ & 52.6 & $<0.1$ & 64.2 & 0.5 & 36 \\
\hline EB-90M & 1.99 & 63 & 2.1 & 1,560 & 521 & 19.5 & 0.95 & $<0.3$ & 64 & 0.42 & 373 & 1 & 143 \\
\hline \multicolumn{14}{|l|}{ Ely Ponds } \\
\hline EM-POND1 & $<0.02$ & 0.03 & $<1$ & 1.1 & 2.7 & $<0.4$ & 0.09 & $<0.3$ & 20.5 & $<0.1$ & 2.3 & $<.08$ & 6.3 \\
\hline EM-POND2 & $<0.02$ & 0.13 & $<1$ & 2.9 & 201 & 0.4 & 0.08 & $<0.3$ & 29.5 & $<0.1$ & 11.5 & 0.6 & 5.4 \\
\hline EM-POND3 & $<0.02$ & 0.23 & $<1$ & 1.7 & 435 & 0.6 & 0.1 & 0.62 & 34.8 & $<0.1$ & 2.4 & 0.6 & 5 \\
\hline EM-POND4 & 0.08 & 0.41 & $<1$ & 13.4 & 212 & 1.3 & 0.1 & $<0.3$ & 38.2 & $<0.1$ & 14.8 & $<.08$ & 8.1 \\
\hline EM-POND5 & 1.02 & 20.4 & $<1$ & 444 & 386 & 7.7 & $<0.05$ & $<0.3$ & 43.4 & $<0.1$ & 143 & 0.6 & 33 \\
\hline EM-POND6 & 2.28 & 46.3 & $<1$ & 1,380 & 564 & 16.7 & 0.4 & 0.52 & 50.4 & 0.2 & 325 & 0.6 & 93 \\
\hline \multicolumn{14}{|c|}{ Schoolhouse Brook } \\
\hline SB-3670M & $<0.02$ & $<0.02$ & $<1$ & $<0.5$ & 5.6 & $<0.4$ & 0.05 & $<0.3$ & 166 & 0.32 & 2.8 & 0.6 & 9 \\
\hline SB-3125M & 0.12 & 4.31 & $<1$ & 42.8 & 43.8 & 1.5 & 0.07 & 0.78 & 157 & 0.31 & 15.6 & 0.6 & 13 \\
\hline SB-2400M & 0.08 & 2.82 & $<1$ & 25 & 31.5 & 1.2 & $<0.05$ & $<0.3$ & 158 & 0.3 & 6.6 & 0.6 & 16 \\
\hline SB-1360M & 0.07 & 1.94 & $<1$ & 21.6 & 19.1 & 1.1 & $<0.05$ & $<0.3$ & 152 & 0.27 & 19.8 & 0.5 & 14 \\
\hline SB-140M & 0.05 & 1.1 & $<1$ & 20.4 & 13.6 & 1 & 0.1 & $<0.3$ & 134 & 0.24 & 12.8 & 0.5 & 13 \\
\hline \multicolumn{14}{|c|}{ Ompompanoosuc River } \\
\hline OR-24050M & $<0.02$ & $<0.02$ & $<1$ & 0.84 & 4.7 & $<0.4$ & 0.08 & $<0.3$ & 138 & 0.24 & 9.3 & 0.6 & 7.2 \\
\hline OR-23630M & 0.02 & 0.11 & $<1$ & 3.3 & 7.1 & $<0.4$ & 0.06 & $<0.3$ & 139 & 0.24 & 12.5 & 0.6 & 8 \\
\hline OR-23200M & 0.1 & 0.31 & $<1$ & 8.9 & 8.9 & 0.5 & 0.2 & $<0.3$ & 139 & 0.24 & 6.9 & 0.5 & 8 \\
\hline
\end{tabular}

${ }^{\text {a }}$ Estimated value, reported concentration is less than the reporting level but greater than the long-term method-detection level. 
Table 5. Constituents in filtered pore waters collected in August and September 2006 from the Ely Mine study area, Vershire, VT.

[The concentrations of the following elements were below their detection limits (given in parentheses in micrograms per liter, $\mu \mathrm{g} / \mathrm{L})$ : $\mathrm{Ag}(<3), \mathrm{As}(<1), \mathrm{Hg}(<5)$, and Mo $(<2)$. S.C., specific conductance; DOC, dissolved organic carbon; $\mu \mathrm{S} / \mathrm{cm}$, microsiemens per centimeter; $\mathrm{mg} / \mathrm{L}$, milligrams per liter; $\mu \mathrm{g} / \mathrm{L}, \mathrm{micrograms}$ per liter; - , not determined; <, analyte not detected at the reporting level; ins, insufficient sample]

\begin{tabular}{|c|c|c|c|c|c|c|c|c|c|c|c|c|c|c|c|c|}
\hline $\begin{array}{l}\text { Stream and } \\
\text { location }\end{array}$ & $\begin{array}{l}\text { Sample } \\
\text { type }\end{array}$ & $\mathrm{pH}$ & $\begin{array}{c}\text { S.C. } \\
(\mu S / c m)\end{array}$ & $\begin{array}{c}\text { Alkalinity } \\
\text { (mg/L as } \\
\mathrm{CaCO}_{3} \text { ) }\end{array}$ & $\begin{array}{c}\text { DOC } \\
\text { (mg/L) }\end{array}$ & $\begin{array}{c}\mathbf{N} \\
(\mathrm{mg} / \mathrm{L})\end{array}$ & $\begin{array}{c}P \\
\text { (mg/L) }\end{array}$ & $\begin{array}{c}\mathrm{Ca} \\
(\mathrm{mg} / \mathrm{L})\end{array}$ & $\begin{array}{c}\text { Fe } \\
(\mu g / L)\end{array}$ & $\begin{array}{c}K \\
(\mathrm{mg} / \mathrm{L})\end{array}$ & $\begin{array}{c}\mathrm{Mg} \\
(\mathrm{mg} / \mathrm{L})\end{array}$ & $\begin{array}{c}\mathrm{Na} \\
(\mathrm{mg} / \mathrm{L})\end{array}$ & $\begin{array}{l}\mathrm{SiO}_{2} \\
\text { (mg/L) }\end{array}$ & $\begin{array}{c}\text { Al } \\
(\mu \mathrm{g} / \mathrm{L})\end{array}$ & $\begin{array}{c}B a \\
(\mu g / L)\end{array}$ & $\begin{array}{c}\text { Be } \\
(\mu g / L)\end{array}$ \\
\hline \multicolumn{17}{|l|}{ Ely Brook } \\
\hline EB-1080M & in situ & 7.1 & 85 & 40 & 1.6 & 0.08 & $0.003 \mathrm{E}^{\mathrm{a}}$ & 12.6 & $<20$ & 1.68 & 1.18 & 1.13 & 9 & 4.3 & 16.6 & $<0.05$ \\
\hline EB-1080M & centrifuge & - & - & 一 & - & - & - & 28 & 436 & 2.78 & 2.53 & 1.71 & 9.7 & 88.8 & 33.4 & $<0.05$ \\
\hline EB-1080M & equilibrated & 7.5 & 389 & 204.8 & - & - & - & 69.5 & $<20$ & 4.84 & 6.42 & 2.79 & 12.7 & 12.2 & 74.7 & $<0.05$ \\
\hline EB-770M & in situ & 6.1 & 131 & 11 & 1 & $0.04 \mathrm{E}$ & $<0.004$ & 14.3 & 145 & 2.16 & 2.41 & 1.41 & 12.8 & 4.8 & 12.9 & $<0.05$ \\
\hline EB-770M & centrifuge & - & - & - & - & - & - & 32 & 32 & 3.45 & 5.38 & 1.95 & 15 & 50.4 & 31.9 & $<0.05$ \\
\hline EB-770M & equilibrated & 6.0 & 400 & 39.6 & - & - & - & 56.1 & 747 & 7.32 & 9.29 & 3.51 & 25.3 & 7 & 64.5 & $<0.05$ \\
\hline EB-600M & in situ & 6.9 & 119 & 15 & 1 & $0.05 \mathrm{E}$ & $0.004 \mathrm{E}$ & 14.4 & $<20$ & 2.13 & 2.29 & 1.4 & 13 & 7.1 & 17 & $<0.05$ \\
\hline EB-600M & centrifuge & - & - & 一 & - & - & - & 16.8 & 52 & 2.6 & 2.56 & 1.47 & 12.4 & 345 & 19.8 & $<0.05$ \\
\hline EB-600M & equilibrated & 7.0 & 164.2 & 30.4 & - & - & - & 21.6 & $<20$ & 4.04 & 3.16 & 2.4 & 15.9 & 15.4 & 26.7 & $<0.05$ \\
\hline EB-90M & in situ & 2.9 & 594 & - & 1.3 & 0.17 & 0.004 & 20.4 & 11,000 & 4.87 & 5.43 & 2.34 & 32.8 & 3,060 & 17.8 & 0.3 \\
\hline EB-90M & centrifuge & - & - & - & - & - & - & 29.1 & 163,100 & 10.3 & 8.58 & 5.42 & 69.8 & 7,520 & 20.6 & 0.3 \\
\hline EB-90M & equilibrated & 3.2 & 1063 & 一 & - & - & - & 28.7 & 47,000 & 5.24 & 7.61 & 4.23 & 39.5 & 6,050 & 21.8 & 0.5 \\
\hline \multicolumn{17}{|c|}{ Schoolhouse Brook } \\
\hline SB-3670M & in situ & 7.7 & 251 & 116 & 1.5 & 0.07 & 0.004 & 41.2 & $<20$ & 2.48 & 1.88 & 4.12 & 7.6 & 6.1 & 23.8 & $<0.05$ \\
\hline SB-3670M & centrifuge & - & - & - & - & - & - & 64.5 & 101 & 3.48 & 2.61 & 4.69 & 10 & 94.1 & 42.5 & $<0.05$ \\
\hline SB-3670M & equilibrated & 7.8 & 561 & 284 & - & - & - & 104 & $<20$ & 5.02 & 4.29 & 6.33 & 11.8 & 16.3 & 75.7 & $<0.05$ \\
\hline SB-2400M & in situ & 7.7 & 347 & 126 & 1 & 0.09 & 0.006 & 46.6 & $<20$ & 4.09 & 3.19 & 16.2 & 10.3 & 12.8 & 26.4 & $<0.05$ \\
\hline SB-2400M & centrifuge & - & - & - & - & - & - & 68.8 & 213 & 4.22 & 6.21 & 15.4 & 11.8 & 197 & 35.4 & $<0.05$ \\
\hline SB-2400M & equilibrated & 7.6 & 563 & 172.8 & - & - & - & 92.1 & 30 & 7.19 & 5.26 & 15.3 & 16.5 & 38.2 & 60.1 & $<0.05$ \\
\hline SB-1360M & in situ & 7.7 & 218 & 92 & 1.6 & 0.24 & 0.006 & 34.6 & $<20$ & 2.81 & 1.95 & 3.78 & 8.8 & 15 & 18.2 & $<0.05$ \\
\hline SB-1360M & centrifuge & - & - & - & - & - & - & 52.1 & 79 & 3.64 & 3.16 & 4.47 & 10 & 76.8 & 29.2 & $<0.05$ \\
\hline SB-1360M & equilibrated & 7.4 & 523 & 190.4 & - & - & - & 93.6 & $<20$ & 7.39 & 5.7 & 6.74 & 16.4 & 8.5 & 68.8 & $<0.05$ \\
\hline SB-140M & in situ & 7.6 & 260 & 107 & 0.9 & 0.15 & $0.004 \mathrm{E}$ & 39.9 & $<20$ & 2.71 & 2.02 & 6.03 & 8.1 & 11.4 & 23.4 & $<0.05$ \\
\hline SB-140M & centrifuge & - & - & 一 & - & - & - & 65.8 & 28 & 3.65 & 3.18 & 5.54 & 9.4 & 14 & 38.9 & $<0.05$ \\
\hline SB-140M & equilibrated & 7.4 & 531 & 212.4 & - & - & - & 101 & $<20$ & 7.31 & 5.66 & 9.68 & 15.8 & 10.7 & 69 & $<0.05$ \\
\hline \multicolumn{17}{|c|}{ Ompompanoosuc River } \\
\hline OR-24050M & in situ & 7.6 & 359 & 150 & 1.4 & 1.04 & 0.006 & 51.6 & $<20$ & 7.18 & 2.99 & 10.9 & 9.8 & 5.4 & 43.3 & $<0.05$ \\
\hline OR-24050M & centrifuge & - & - & - & - & - & - & 68.5 & 30 & 7.99 & 4.05 & 12.6 & 10.6 & ins & ins & ins \\
\hline OR-24050M & equilibrated & 7.9 & 709 & - & - & - & - & 137 & $<20$ & 12.9 & 7.78 & 16.5 & 16.1 & 21.51 & 126 & $<0.05$ \\
\hline OR-23200M & in situ & 7.6 & 277 & 105 & 1.4 & 0.2 & 0.005 & 35.8 & $<20$ & 3.18 & 1.47 & 14.9 & 7.8 & 12.9 & 21.6 & $<0.05$ \\
\hline OR-23200M & centrifuge & - & - & - & - & - & - & 68.9 & 23 & 3.73 & 3.51 & 10.6 & 8.1 & 38.5 & 48.2 & $<0.05$ \\
\hline OR-23200M & equilibrated & 7.4 & 535 & 250.8 & - & - & - & 86.8 & $<20$ & 5.46 & 4.04 & 16.8 & 14.5 & 11.6 & 77.5 & $<0.05$ \\
\hline
\end{tabular}


Table 5. Constituents in filtered pore waters collected in August and September 2006 from the Ely Mine study area, Vershire, VT.Continued

[The concentrations of the following elements were below their detection limits (given in parentheses in micrograms per liter, $\mu \mathrm{g} / \mathrm{L})$ : $\mathrm{Ag}(<3), \mathrm{As}(<1), \mathrm{Hg}(<5)$, and Mo $(<2)$. S.C., specific conductance; DOC, dissolved organic carbon; $\mu \mathrm{S} / \mathrm{cm}$, microsiemens per centimeter; $\mathrm{mg} / \mathrm{L}$, milligrams per liter; $\mu \mathrm{g} / \mathrm{L}, \mathrm{micrograms}$ per liter; - , not determined; $<$, analyte not detected at the reporting level; ins, insufficient sample]

\begin{tabular}{|c|c|c|c|c|c|c|c|c|c|c|c|c|c|c|c|c|c|}
\hline $\begin{array}{l}\text { Stream and } \\
\text { location }\end{array}$ & $\begin{array}{l}\text { Sample } \\
\text { type }\end{array}$ & $\begin{array}{c}\text { Cd } \\
(\mu g / L)\end{array}$ & $\begin{array}{c}\text { Co } \\
(\mu g / L)\end{array}$ & $\begin{array}{c}\mathrm{Cr} \\
(\mu \mathrm{g} / \mathrm{L})\end{array}$ & $\underset{(\mu \mathrm{g} / \mathrm{L})}{\mathrm{Cu}}$ & $\underset{(\mu g / L)}{M n}$ & $\begin{array}{c}\mathrm{Ni} \\
(\mu \mathrm{g} / \mathrm{L})\end{array}$ & $\begin{array}{c}\mathrm{Pb} \\
(\mu \mathrm{g} / \mathrm{L})\end{array}$ & $\begin{array}{c}S b \\
(\mu g / L)\end{array}$ & $\begin{array}{c}\text { Se } \\
(\mu \mathrm{g} / \mathrm{L})\end{array}$ & $\begin{array}{c}\mathrm{Sr} \\
(\mu \mathrm{g} / \mathrm{L})\end{array}$ & $\begin{array}{c}\text { TI } \\
(\mu \mathrm{g} / \mathrm{L})\end{array}$ & $\underset{(\mu \mathrm{g} / \mathrm{L})}{U}$ & $\begin{array}{c}V \\
(\mu \mathrm{g} / \mathrm{L})\end{array}$ & $\begin{array}{c}\mathrm{Zn} \\
(\mu \mathrm{g} / \mathrm{L})\end{array}$ & $\begin{array}{c}\mathrm{Cl} \\
(\mathrm{mg} / \mathrm{L})\end{array}$ & $\begin{array}{c}\mathrm{SO}_{4} \\
(\mathrm{mg} / \mathrm{L})\end{array}$ \\
\hline \multicolumn{18}{|l|}{ Ely Brook } \\
\hline EB-1080M & in situ & $<0.02$ & $<0.02$ & $<1$ & 2.4 & 0.3 & 0.6 & 0.06 & $<0.3$ & $<1$ & 46.1 & $<0.1$ & $<0.1$ & $<0.5$ & 1.5 & 1.4 & 4.4 \\
\hline EB-1080M & centrifuge & 1.66 & 0.46 & $<1$ & 10.2 & 45.7 & 1.4 & 0.91 & $<0.3$ & $<1$ & 92.4 & $<0.1$ & $<0.1$ & 0.8 & 29.2 & - & 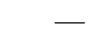 \\
\hline EB-1080M & equilibrated & 0.11 & 0.55 & $<1$ & 4.3 & 2,520 & 1.7 & $<0.05$ & $<0.3$ & 1.8 & 225 & $<0.1$ & 0.49 & $<0.5$ & 1.6 & 3.2 & 14 \\
\hline EB-770M & in situ & 0.28 & 2.36 & $<1$ & 27.4 & 41.1 & 4.3 & 0.2 & $<0.3$ & $<1$ & 51 & $<0.1$ & $<0.1$ & $<0.5$ & 25.1 & 1.4 & 43 \\
\hline EB-770M & centrifuge & 1.25 & 61.7 & $<1$ & 43.4 & 2,780 & 12.6 & $<0.05$ & $<0.3$ & 1.2 & 102 & $<0.1$ & $<0.1$ & $<0.5$ & 50 & - & 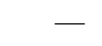 \\
\hline EB-770M & equilibrated & 1.95 & 71.3 & $<1$ & 106 & 5,460 & 20 & $<0.05$ & $<0.3$ & 1 & 195 & $<0.1$ & $<0.1$ & $<0.5$ & 114 & 2.8 & 175 \\
\hline EB-600M & in situ & 0.3 & 2.37 & $<1$ & 42.7 & 14.8 & 4 & $<0.05$ & $<0.3$ & $<1$ & 50.4 & $<0.1$ & $<0.1$ & $<0.5$ & 31.6 & 1.4 & 35 \\
\hline EB-600M & centrifuge & 0.34 & 2.15 & $<1$ & 108 & 26.5 & 3.9 & 0.08 & $<0.3$ & $<1$ & 56.2 & $<0.1$ & $<0.1$ & $<0.5$ & 24.8 & - & - \\
\hline EB-600M & equilibrated & 0.59 & 8.24 & $<1$ & 59.6 & 418 & 4.5 & $<0.05$ & $<0.3$ & $<1$ & 71.9 & $<0.1$ & $<0.1$ & $<0.5$ & 26 & 1.5 & 47 \\
\hline EB-90M & in situ & 1.85 & 57.9 & 1.4 & 1,800 & 501 & 17.4 & 1.9 & 0.77 & 1.2 & 63.1 & 0.1 & 0.46 & $<0.5$ & 314 & 3.4 & 161 \\
\hline EB-90M & centrifuge & 2.87 & 272 & 2.1 & 2,140 & 2,810 & 31.1 & 1.2 & $<0.3$ & 2.6 & 82 & 0.1 & 0.69 & $<0.5$ & 514 & - & \\
\hline EB-90M & equilibrated & 2.62 & 246 & 1.4 & 1,700 & 3,150 & 39 & 1.7 & $<0.3$ & 2.9 & 113 & 0.2 & 1.01 & $<0.5$ & 616 & 7 & 574 \\
\hline \multicolumn{18}{|c|}{ Schoolhouse Brook } \\
\hline SB-3670M & in situ & $<0.02$ & $<0.02$ & $<1$ & $<0.5$ & 0.4 & $<0.4$ & 0.06 & $<0.3$ & $<1$ & 191 & $<0.1$ & 0.26 & $<0.5$ & 1.9 & 3.5 & 6 \\
\hline SB-3670M & centrifuge & 0.04 & 0.12 & $<1$ & 1 & 6.8 & 2.4 & 0.1 & $<0.3$ & $<1$ & 274 & $<0.1$ & 0.42 & 0.6 & 3.8 & 一 & - \\
\hline SB-3670M & equilibrated & 0.04 & 0.68 & $<1$ & 2.9 & 3,870 & 4.1 & 0.1 & 0.88 & $<1$ & 457 & 0.2 & 1.07 & 1 & 4.4 & 7 & 16 \\
\hline SB-2400M & in situ & 0.08 & 0.28 & $<1$ & 7.9 & 113 & 0.5 & $<0.05$ & 0.53 & $<1$ & 209 & $<0.1$ & 0.33 & $<0.5$ & 3 & - & - \\
\hline SB-2400M & centrifuge & 0.15 & 1.1 & $<1$ & 16.8 & 149 & 2.9 & 0.1 & 0.33 & 1.2 & 285 & $<0.1$ & 0.54 & $<0.5$ & 6.4 & - & - \\
\hline SB-2400M & equilibrated & 0.3 & 2.44 & $<1$ & 22.8 & 1,030 & 2.6 & 0.05 & 0.3 & 1.5 & 430 & 0.1 & 0.72 & $<0.5$ & 4.9 & 14 & 99 \\
\hline SB-1360M & in situ & 0.05 & 0.13 & $<1$ & 9.6 & 31.5 & 0.8 & 0.2 & $<0.3$ & $<1$ & 159 & $<0.1$ & 0.23 & $<0.5$ & 149 & 4 & 17 \\
\hline SB-1360M & centrifuge & 0.17 & 1.59 & $<1$ & 18.1 & 171 & 2.2 & 0.09 & 0.44 & 1.3 & 224 & $<0.1$ & 0.37 & $<0.5$ & 6 & - & . \\
\hline SB-1360M & equilibrated & 0.27 & 4.28 & $<1$ & 24.9 & 1,770 & 2.2 & $<0.05$ & $<0.3$ & 1.1 & 436 & $<0.1$ & 0.62 & $<0.5$ & 7 & 6.1 & 87 \\
\hline SB-140M & in situ & 0.04 & 0.03 & $<1$ & 5.6 & 0.6 & 0.6 & 0.2 & $<0.3$ & $<1$ & 168 & $<0.1$ & 0.2 & $<0.5$ & 8 & 7.1 & 16 \\
\hline SB-140M & centrifuge & 0.22 & 1.05 & $<1$ & 8.5 & 209 & 2.6 & 0.1 & $<0.3$ & $<1$ & 272 & $<0.1$ & 0.4 & $<0.5$ & 5.3 & - & 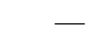 \\
\hline SB-140M & equilibrated & 0.4 & 3.81 & $<1$ & 21.6 & 1,100 & 2.2 & 0.1 & $<0.3$ & 1 & 397 & $<0.1$ & 0.62 & $<0.5$ & 7.4 & 7 & 64 \\
\hline \multicolumn{18}{|c|}{ Ompompanoosuc River } \\
\hline \multirow{2}{*}{\multicolumn{2}{|c|}{$\begin{array}{l}\text { OR-24050M in situ } \\
\text { OR-24050M centrifuge }\end{array}$}} & $<0.02$ & 0.03 & $<1$ & \multicolumn{2}{|c|}{0.56196} & 0.4 & $<0.05$ & $<0.3$ & $<1$ & 228 & $<0.1$ & 0.4 & $<0.5$ & 3.8 & 15 & 10 \\
\hline & & ins & ins & ins & ins & ins & ins & ins & ins & ins & ins & ins & ins & ins & ins & - & - \\
\hline OR-24050M & I equilibrated & 0.04 & 0.74 & $<1$ & 1.6 & 6,270 & 3.8 & 0.09 & $<0.3$ & 1.2 & 559 & $<0.1$ & 1.91 & 1.8 & 2.4 & 15 & 11 \\
\hline OR-23200M & 1 in situ & 0.06 & 0.47 & 1.9 & 4.5 & 327 & 0.8 & 0.3 & $<0.3$ & $<1$ & 150 & $<0.1$ & 0.32 & $<0.5$ & 2.9 & 15 & 11 \\
\hline OR-23200M & I centrifuge & 0.19 & 3.08 & $<1$ & 14.2 & 1,500 & 2.8 & 0.09 & $<0.3$ & $<1$ & 282 & $<0.1$ & 0.7 & 1 & 3.4 & - & . \\
\hline OR-23200M & I equilibrated & 0.09 & 2.08 & $<1$ & 19.1 & 3,500 & 2.2 & 0.2 & $<0.3$ & $<1$ & 386 & $<0.1$ & 0.95 & $<0.5$ & 5.7 & 12 & 25 \\
\hline
\end{tabular}

\footnotetext{
${ }^{a}$ Estimated value, reported concentration is less than the reporting level but greater than the long-term method-detection level.
} 
headwaters of Ely Brook ranged from 7.0 to 7.2, compared to 8.0 to 8.2 for Schoolhouse Brook and the Ompompanoosuc River (fig. 5). Likewise, specific conductance ranged from 51 to 87 microsiemens per centimeter $(\mu \mathrm{S} / \mathrm{cm})$ for the Ely Brook headwaters, and from 196 to $212 \mu \mathrm{S} / \mathrm{cm}$ for the receiving water bodies (fig. 5). Calcium was the dominant dissolved cation (5.8 to $35.7 \mathrm{mg} / \mathrm{L})$, and $\mathrm{Mg}$ (1.1 to $1.7 \mathrm{mg} / \mathrm{L}), \mathrm{Na}(1.1$ to $5.2 \mathrm{mg} / \mathrm{L})$, and $\mathrm{K}$ (1.7 to $2.3 \mathrm{mg} / \mathrm{L})$ occur in subequal proportions. Silica $\left(\mathrm{SiO}_{2}\right.$ ) ranged from 2.2 to $9.1 \mathrm{mg} / \mathrm{L}$ and was lowest in pond 1. Alkalinity was the dominant anionic species (19 to $99 \mathrm{mg} / \mathrm{L} \mathrm{CaCO}_{3}$ equivalent) (fig. 6). The increased

\section{A}

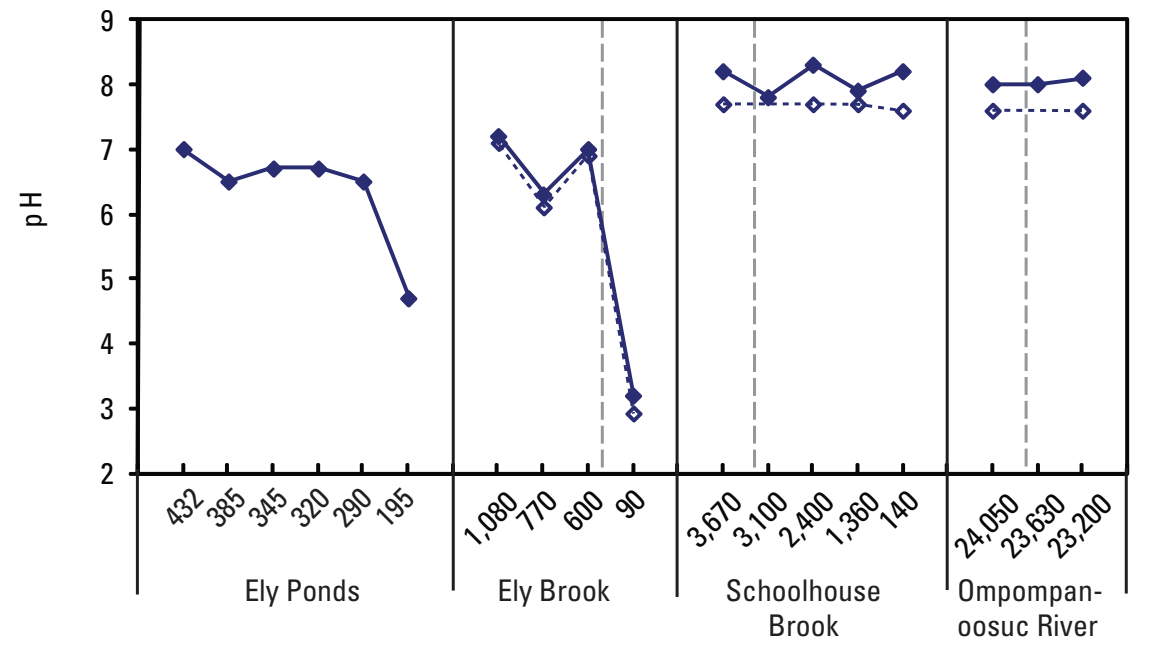

B

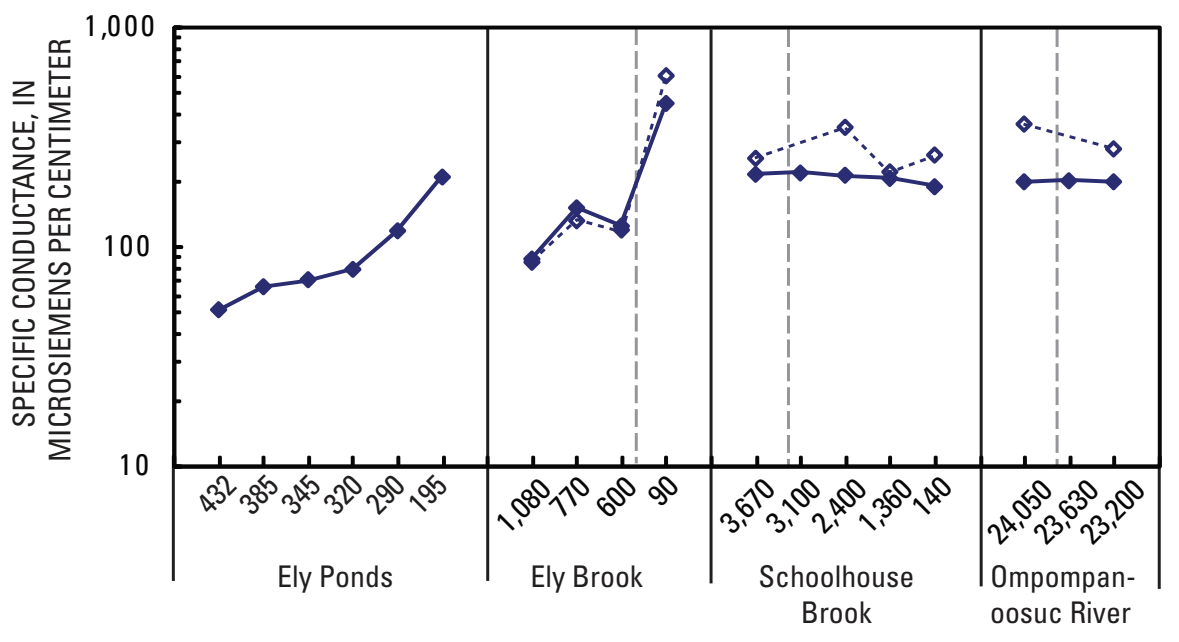

RIVER METER AND REACH specific conductance of the receiving water bodies was dominantly reflected in higher concentrations of $\mathrm{Ca}, \mathrm{Mg}, \mathrm{Na}$, and alkalinity compared to the headwaters of Ely Brook. Likewise, hardness values for the head waters (19 to $41 \mathrm{mg} / \mathrm{L} \mathrm{CaCO}_{3}$ equivalent) were lower than those for the receiving water bodies (86 to $97 \mathrm{mg} / \mathrm{L} \mathrm{CaCO}_{3}$ equivalent) (fig. 6).

\section{Iron, Aluminum, and Manganese}

Iron, aluminum, and manganese generally had low concentrations in the background waters at the site (fig. 7).

For all background sites, dissolved iron ranged from below the detection limit $(<20 \mu \mathrm{g} / \mathrm{L})$ to just above $(66 \mu \mathrm{g} / \mathrm{L})$. Likewise, dissolved aluminum concentrations ranged from 3.4 to $13.4 \mu \mathrm{g} / \mathrm{L}$. Dissolved manganese concentrations were slightly higher and ranged from 4.7 to $124 \mu \mathrm{g} / \mathrm{L}$.

\section{Minor and Trace Inorganic Elements}

Minor and trace elements generally have low concentrations in the background waters at the site (fig. 7). Dissolved Ag, As, Cd, Cr, Hg, Sb, and Se concentrations were all below their detection limits. Dissolved Ba concentrations ranged from 18.4 to $20.5 \mu \mathrm{g} / \mathrm{L}$, dissolved $\mathrm{Cu}$ from $<0.5$ to $1.3 \mu \mathrm{g} / \mathrm{L}$, dissolved Ni from $<0.4$ to $0.5 \mu \mathrm{g} / \mathrm{L}$, dissolved $\mathrm{Pb}$ from $<0.05$ to $0.09 \mu \mathrm{g} / \mathrm{L}$, and dissolved $\mathrm{Zn}$ from 2.3 to $9.3 \mu \mathrm{g} / \mathrm{L}$. HIs $(\mathrm{Cd}+\mathrm{Cu}+\mathrm{Ni}+\mathrm{Pb}+\mathrm{Zn})$ comparing surface-water quality at these sites to hardness-based chronic ambient water-quality standards were all below 1 $(0.05-0.82)$ for these sites.

\section{Dissolved Organic Carbon and Nutrients}

Dissolved organic carbon (DOC) concentrations in background waters throughout the study area ranged from 1.2 to $3.5 \mathrm{mg} / \mathrm{L}$, with pond 1 having the highest values. Nutrients were generally low throughout the study area. Total dissolved nitrogen ranged from 0.07 to $0.46 \mathrm{mg} / \mathrm{L}$, and total dissolved phosphorus ranged from 0.002 to $0.036 \mathrm{mg} / \mathrm{L}$.

Figure 5. Downstream variations in $(A) \mathrm{pH}$ and $(B)$ specific conductance in surface and in situ pore waters at the Ely Mine Superfund site, Vershire, VT. 
A

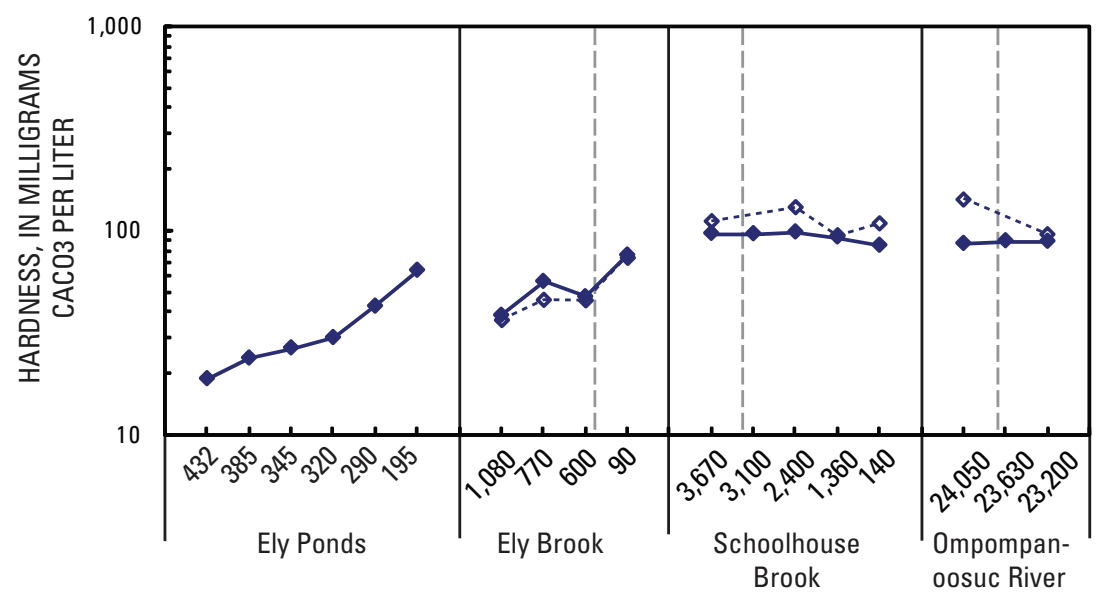

B

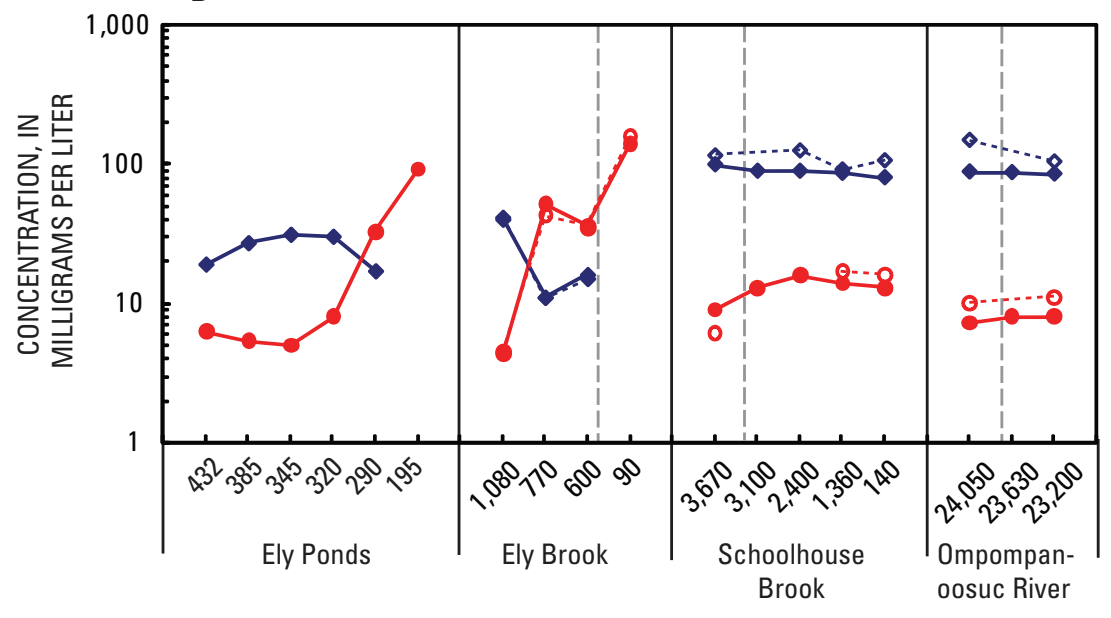

RIVER METER AND REACH

Explanation

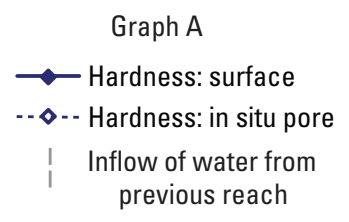

Graph B

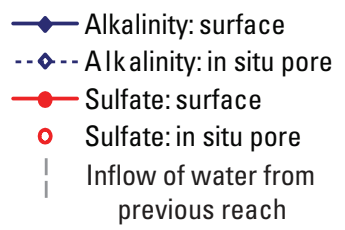

Figure 6. Downstream variations in $(A)$ hardness, $(B)$ alkalinity and sulfate concentrations in surface and in situ pore waters at the Ely Mine Superfund site, Vershire, VT.

\section{Comparisons with Ambient Water-Quality Criteria}

Water-quality data for background reaches are best interpreted in terms of proximity to the Ely Mine site. Ely Brook background conditions were characterized by those locations above the confluence with Ely Brook tributary 4 (river meter 800 ). Ely Brook tributary 2 background conditions were characterized by those locations above a series of waste-rock piles and seeps (river meter 340). Schoolhouse Brook background conditions were characterized by those locations above the confluence with Ely Brook (river meter $3,270)$. The Ompompanoosuc River background conditions were characterized by locations above the confluence with Schoolhouse Brook (river meter 23,640). Background concentrations for most elements were less than AWQC with the exception being aluminum, which was greater than AWQC in all background reaches (appendix 5).

\section{Pore-Water Geochemistry}

Background pore-water samples were collected from all of the same sites as surfacewater samples except for pond 1. These sites include EB-1080M for Ely Brook, SB-3670M for Schoolhouse Brook, and OR-24050M for the Ompompanoosuc River. Minor but significant differences among the chemistry of the three types of pore-water samples were noted. Field parameters and chemical constituents for pore-water samples are summarized in table 5, and complete analyses are reported in appendix 7 .

\section{Field Parameters and Major Inorganic Constituents}

The $\mathrm{pH}$ and specific conductance were measured only on the in situ and equilibrated samples. Collectively, the background pore waters are near neutral with $\mathrm{pH}$ ranging from 7.1 to 7.9 (fig. 5). Invariably, the $\mathrm{pH}$ of the equilibrated water samples was 0.1 to 0.4 unit higher than the corresponding in situ values. As with the surface water, the specific conductance increased with increasing size of the catchment, going from Ely Brook to Schoolhouse Brook to the Ompompanoosuc River (fig. 5). The values from equilibrated pore waters (389-709 $\mu \mathrm{S} / \mathrm{cm})$ were higher than those from the in situ pore waters $(85-359 \mu \mathrm{S} / \mathrm{cm})$ by roughly 100 to 350 percent.

Calcium was the dominant dissolved cation, and $\mathrm{Mg}, \mathrm{Na}$, and $\mathrm{K}$ occurred in subequal proportions, similar to the surface-water samples. Invariably, the concentrations of dissolved major cations (Ca: $69.5-137 \mathrm{mg} / \mathrm{L} ; \mathrm{Mg}: 6.4-7.8 \mathrm{mg} / \mathrm{L}$; $\mathrm{Na}: 2.8-16.5 \mathrm{mg} / \mathrm{L}$; $\mathrm{K}: 4.8-12.9 \mathrm{mg} / \mathrm{L}$ ) were highest in the equilibrated samples and lowest in the in situ samples (Ca: 12.6-51.6 mg/L; Mg: $1.2-3.0 \mathrm{mg} / \mathrm{L} ; \mathrm{Na}: 1.1-10.9 \mathrm{mg} / \mathrm{L} ; \mathrm{K}$ : $1.7-7.2 \mathrm{mg} / \mathrm{L})$. Dissolved silica $\left(\mathrm{SiO}_{2}\right)$ concentrations also were highest in the equilibrated samples and lowest in the in situ samples. The concentrations of silica from all sample types ranged from 7.6 to $16.1 \mathrm{mg} / \mathrm{L}$. Alkalinity was the dominant anionic species, and like the major cations, was found in 
A

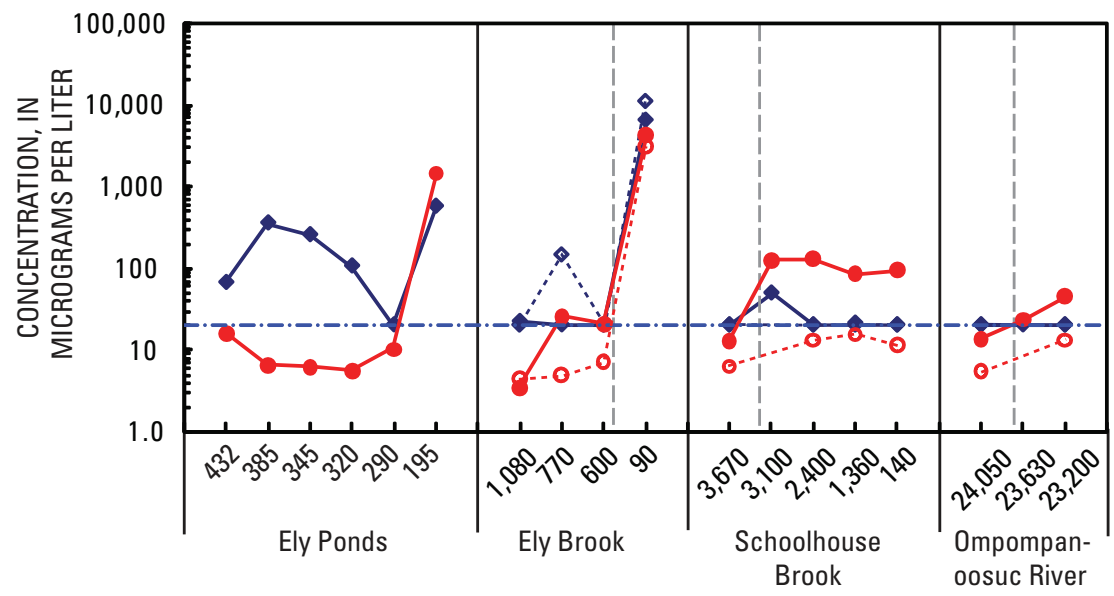

B

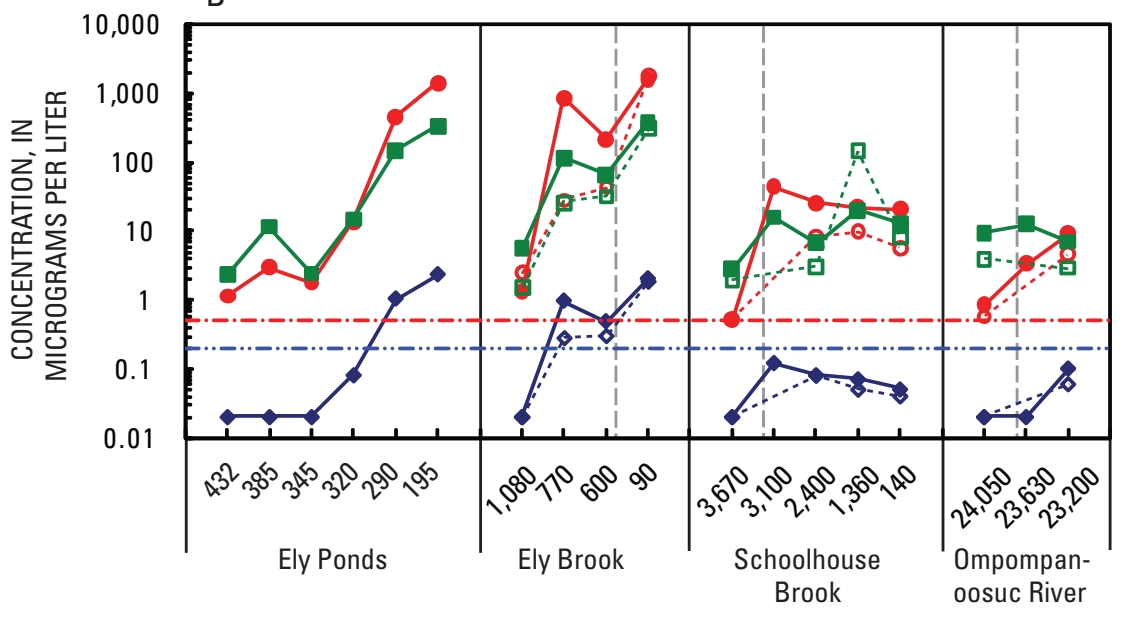

RIVER METER AND REACH

Explanation

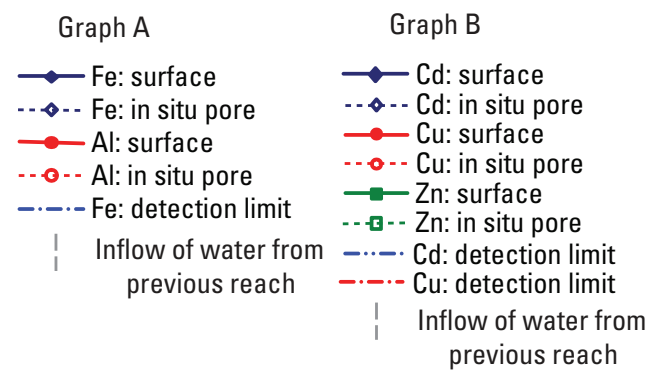

Figure 7. Downstream variations in $(A)$ aluminum, iron, $(B)$ cadmium, copper, and zinc concentrations in surface and in situ pore waters at the Ely Mine Superfund site, Vershire, VT.

higher concentrations in the equilibrated samples than in the in situ samples (fig. 6). Similarly, the alkalinity concentrations of pore waters increased with increasing drainage area in background sites. The alkalinity values of the in situ pore waters ranged from 40 to $150 \mathrm{mg} / \mathrm{L} \mathrm{CaCO}_{3}$ equivalent. Sulfate and chloride occurred in subequal concentrations in porewater samples and reached maximum concentrations of 10 and
$15 \mathrm{mg} / \mathrm{L}$, respectively, in the in situ samples (fig. 6). The hardness values of the pore waters followed identical trends. The hardness values increased with catchment area (fig. 6). Invariably, the in situ samples had the lowest values (36.3 to $141.3 \mathrm{mg} / \mathrm{L} \mathrm{CaCO}_{3}$ equivalent), and the 28-day equilibrated samples had the highest (200.1 to $374.4 \mathrm{mg} / \mathrm{L}$ $\mathrm{CaCO}_{3}$ equivalent).

\section{Iron, Aluminum, and Manganese}

Iron, aluminum, and manganese generally had low concentrations in the background pore waters at the site (fig. 7). For all background sites, dissolved iron was below the detection limit $(<20 \mu \mathrm{g} / \mathrm{L})$ for the in situ and equilibrated splits but ranged from 30 to $436 \mu \mathrm{g} / \mathrm{L}$ in the centrifuged splits with the highest concentrations occurring in the Ely Brook headwaters and the lowest in the Ompompanoosuc River headwaters. Dissolved aluminum concentrations ranged from 4.3 to $94.1 \mu \mathrm{g} / \mathrm{L}$ with the highest concentrations in the centrifuged splits. Dissolved manganese concentrations were slightly higher and ranged from 0.3 to $6,270 \mu \mathrm{g} / \mathrm{L}$ with concentrations increasing with catchment area. The in situ samples had the lowest concentrations, and the equilibrated samples had the highest, up to two orders of magnitude higher.

\section{Minor and Trace Inorganic Elements}

Minor and trace elements generally had low concentrations in the background pore waters at the site (fig. 7). Dissolved $\mathrm{Ag}, \mathrm{As}, \mathrm{Cr}$, and $\mathrm{Hg}$ concentrations were all below their detection limits. Dissolved Ba concentrations ranged from 16.6 to $126 \mu \mathrm{g} / \mathrm{L}$, dissolved $\mathrm{Cd}$ from $<0.02$ to $1.7 \mu \mathrm{g} / \mathrm{L}$, dissolved $\mathrm{Cu}$ from $<0.5$ to $10.2 \mu \mathrm{g} / \mathrm{L}$, dissolved $\mathrm{Ni}$ from $<0.4$ to $4.1 \mu \mathrm{g} / \mathrm{L}$, dissolved $\mathrm{Pb}$ from $<0.05$ to $0.9 \mu \mathrm{g} / \mathrm{L}$, dissolved $\mathrm{Sb}$ from $<0.3$ to $0.9 \mu \mathrm{g} / \mathrm{L}$, dissolved Se from $<1$ to $1.8 \mu \mathrm{g} / \mathrm{L}$, and dissolved $\mathrm{Zn}$ from 1.5 to $29.2 \mu \mathrm{g} / \mathrm{L}$. HIs for background pore-water samples were all below $1(0.00-0.91)$ with the exception of the centrifuged split for EB-1080M, which had an index of 9.6 due to elevated concentrations of copper and especially cadmium.

\section{Dissolved Organic Carbon and Nutrients}

DOC and nutrient concentrations were determined only on samples of in situ pore water. DOC concentrations throughout the study area ranged from 1.4 to $1.6 \mathrm{mg} / \mathrm{L}$. Nutrients were 
generally low throughout the study area. Total dissolved nitrogen ranged from 0.07 to $1.04 \mathrm{mg} / \mathrm{L}$, and total dissolved phosphorus ranged from 0.003 to $0.006 \mathrm{mg} / \mathrm{L}$ with the Ompompanoosuc River having the highest concentrations.

\section{Comparisons with Ambient Water-Quality Criteria}

Background concentrations for most elements in pore waters were less than AWQC with the exception being aluminum, cadmium, and copper (appendix 7). Concentrations of these elements exceeded AWQC only locally for the centrifuged pore-water samples. Concentrations of aluminum in the centrifuged background pore-water samples from Ely Brook and Schoolhouse Brook exceeded the chronic AWQC. Concentrations of cadmium in the centrifuged background porewaters samples from Ely Brook exceeded both the acute and chronic AWQC. Concentrations of copper in the centrifuged background pore-water samples from Ely Brook exceeded only the chronic AWQC.

\section{Sediment Geochemistry}

The major-element geochemistry of background sediments reflects their siliciclastic constituents. Chemical constituents for sediment samples are summarized in table 6, and complete analyses are reported in appendix 8. SEM-AVS data for sediment samples are summarized in table 7, and complete analyses are reported in appendix 4 . Aluminum ranged from 3.1 to 4.3 weight percent in the background streams and was 6.7 weight percent in pond 1 . The higher concentration of aluminum in the pond probably reflected a higher proportion of clays compared to the higher energy stream settings. Na, $\mathrm{K}, \mathrm{Ca}$, and $\mathrm{Mg}$ all ranged from 0.7 to 1.9 weight percent. Iron ranged from 1.4 to 2.8 weight percent in the stream sediments, and reached 4.4 weight percent in the pond 1 sediments. Carbonate carbon was low, between 0.01 and 0.20 weight percent carbon, whereas total organic carbon in the stream sediments ranged from 0.32 to 0.37 weight percent, and was 8.0 weight percent in pond 1.

Table 6. Select chemistry results for sediments collected in August and September 2006 from the Ely Mine study area, Vershire, VT.

[wt. \%, weight percent; mg/kg, milligrams per kilogram; - , not determined; <, analyte not detected at the reporting level]

\begin{tabular}{|c|c|c|c|c|c|c|c|c|c|c|c|c|c|c|c|}
\hline $\begin{array}{l}\text { Stream and } \\
\text { location }\end{array}$ & $\begin{array}{c}\text { Total C } \\
\text { (wt. \% } \\
\text { as C) }\end{array}$ & $\begin{array}{c}\mathrm{CO}_{2} \\
\text { (wt. \% } \\
\text { as C) }\end{array}$ & $\begin{array}{c}\text { Carbonate } \\
\text { (wt. \% } \\
\text { as C) }\end{array}$ & $\begin{array}{c}\text { Total } \\
\text { organic C } \\
\text { (wt. \% as C) }\end{array}$ & $\begin{array}{c}\text { Al } \\
\text { (wt. \%) }\end{array}$ & $\begin{array}{c}\text { Ca } \\
\text { (wt. \%) }\end{array}$ & $\begin{array}{c}\text { Fe } \\
\text { (wt. \%) }\end{array}$ & $\begin{array}{c}\text { K } \\
\text { (wt. \%) }\end{array}$ & $\begin{array}{c}\text { Mg } \\
\text { (wt. \%) }\end{array}$ & $\begin{array}{c}\mathrm{Na} \\
\text { (wt. \%) }\end{array}$ & $\begin{array}{c}\text { S } \\
\text { (wt. \%) }\end{array}$ & $\begin{array}{c}\mathrm{Ag} \\
(\mathrm{mg} / \mathrm{kg})(\end{array}$ & $\begin{array}{c}\text { As } \\
(\mathrm{mg} / \mathrm{kg})\end{array}$ & $\begin{array}{c}\mathrm{Ba} \\
(\mathrm{mg} / \mathrm{kg})\end{array}$ & $\begin{array}{c}\text { Cd } \\
(\mathrm{mg} / \mathrm{kg})\end{array}$ \\
\hline $\mathrm{PEC}^{\mathrm{a}}$ & - & - & - & - & - & - & - & - & - & - & - & - & 33 & - & 4.98 \\
\hline \multicolumn{16}{|l|}{ Ely Brook } \\
\hline EB-1080M & 0.35 & 0.04 & 0.01 & 0.34 & 4.26 & 1.05 & 2.76 & 1.03 & 0.98 & 1 & 0.04 & $<1$ & $<1$ & 249 & 0.1 \\
\hline EB-770M & 0.55 & 0.07 & 0.02 & 0.53 & 4.81 & 1.24 & 5.5 & 1.06 & 1.01 & 1.06 & 0.3 & $<1$ & 2 & 255 & 0.4 \\
\hline EB-600M & 0.25 & 0.09 & 0.02 & 0.23 & 4.66 & 1.25 & 7.09 & 1.05 & 1.05 & 1.05 & 0.41 & $<1$ & 3 & 236 & 1 \\
\hline EB-90M & 0.28 & 0.06 & 0.02 & 0.26 & 3.98 & 1.13 & 16.7 & 0.95 & 0.76 & 1.06 & 1.7 & 3 & 2 & 166 & 1 \\
\hline $\begin{array}{l}\text { EB-90M-OBS } \\
\text { (overbank } \\
\text { sed.) }\end{array}$ & 2.46 & 0.15 & 0.04 & 2.42 & 3.21 & 0.31 & 36.3 & 2.45 & 0.7 & 0.56 & 4.66 & 17 & 4 & 360 & 0.2 \\
\hline EB-20M & 0.55 & 0.08 & 0.02 & 0.53 & 4.12 & 1.08 & 14.6 & 1.03 & 0.73 & 1.19 & 1.41 & 3 & 2 & 191 & 0.7 \\
\hline \multicolumn{16}{|l|}{ Ely Ponds } \\
\hline EM-POND1 & 8.04 & 0.16 & 0.04 & 8 & 6.68 & 1.93 & 4.39 & 0.89 & 1.56 & 1.78 & 0.42 & $<1$ & $<1$ & 276 & 0.8 \\
\hline EM-POND2 & 9.36 & 0.23 & 0.06 & 9.3 & 6.12 & 1.89 & 4.48 & 1.09 & 1.38 & 1.3 & 0.54 & $<1$ & $<1$ & 321 & 1.3 \\
\hline EM-POND3 & 10.4 & 0.26 & 0.07 & 10.33 & 5.49 & 1.47 & 5.84 & 0.84 & 1.22 & 0.91 & 0.37 & $<1$ & 3 & 377 & 1.2 \\
\hline EM-POND4 & 10.1 & 0.18 & 0.05 & 10.05 & 5.63 & 1.11 & 3.88 & 1.11 & 1.25 & 0.69 & 0.34 & $<1$ & 7 & 337 & 2.5 \\
\hline EM-POND5 & 9.57 & 0.26 & 0.07 & 9.5 & 6.45 & 0.92 & 4.99 & 0.79 & 1.02 & 0.89 & 0.71 & $<1$ & 3 & 296 & 4 \\
\hline EM-POND6 & 6.54 & 0.27 & 0.07 & 6.47 & 11.1 & 0.67 & 3.5 & 0.75 & 0.73 & 0.65 & 0.93 & $<1$ & 3 & 184 & 0.2 \\
\hline \multicolumn{16}{|c|}{ Schoolhouse Brook } \\
\hline SB-3670M & 0.52 & 0.75 & 0.2 & 0.32 & 3.1 & 1.42 & 1.39 & 0.81 & 0.66 & 0.68 & 0.03 & $<1$ & 3 & 207 & $<0.1$ \\
\hline SB-3260M & 0.39 & 0.48 & 0.13 & 0.26 & 3.56 & 1.43 & 5.88 & 0.82 & 0.62 & 0.8 & 0.42 & $<1$ & 2 & 173 & 0.3 \\
\hline SB-2400M & 0.41 & 0.69 & 0.19 & 0.22 & 3.61 & 1.34 & 2.03 & 0.86 & 0.63 & 0.76 & 0.08 & $<1$ & 1 & 191 & 0.1 \\
\hline SB-1360M & 0.4 & 0.56 & 0.15 & 0.25 & 3.48 & 1.62 & 2.78 & 0.85 & 0.67 & 0.79 & 0.1 & $<1$ & 1 & 191 & 0.2 \\
\hline SB-140M & 0.34 & 0.35 & 0.1 & 0.24 & 3.69 & 1.3 & 2.63 & 0.92 & 0.62 & 0.79 & 0.08 & $<1$ & 1 & 198 & 0.2 \\
\hline \multicolumn{16}{|c|}{ Ompompanoosuc River } \\
\hline OR-24050M & 0.41 & 0.15 & 0.04 & 0.37 & 3.27 & 1.13 & 1.4 & 0.8 & 0.73 & 0.72 & 0.02 & $<1$ & 3 & 187 & $<0.1$ \\
\hline OR-23200M & 0.3 & 0.17 & 0.05 & 0.25 & 3.54 & 1.3 & 2.28 & 0.84 & 0.71 & 0.76 & 0.03 & $<1$ & 5 & 195 & 0.1 \\
\hline
\end{tabular}


The concentrations of most trace elements were low, with the exception of $\mathrm{Cr}, \mathrm{Cu}$, and $\mathrm{Ni}$. Maximum concentrations in the background stream and pond sediments were 3 milligrams per kilogram (mg/kg) for As, $0.07 \mathrm{mg} / \mathrm{kg}$ for $\mathrm{Hg}, 0.8 \mathrm{mg} / \mathrm{kg}$ for $\mathrm{Cd}, 102 \mathrm{mg} / \mathrm{kg}$ for $\mathrm{Cr}, 86.6 \mathrm{mg} / \mathrm{kg}$ for $\mathrm{Cu}, 35.6 \mathrm{mg} / \mathrm{kg}$ for $\mathrm{Ni}$, $26.4 \mathrm{mg} / \mathrm{kg}$ for $\mathrm{Pb}, 0.7 \mathrm{mg} / \mathrm{kg}$ for $\mathrm{Se}$, and $126 \mathrm{mg} / \mathrm{kg}$ for $\mathrm{Zn}$.

Acid volatile sulfide for the stream-sediment samples for background sites was below the detection limit of $23 \mathrm{mg} / \mathrm{kg}$ ( 0.7 micromoles per gram, $\mu \mathrm{mol} / \mathrm{g}$ ) for all background stream sediments. The sum of the concentrations of simultaneously extracted metals $(\mathrm{Cd}+\mathrm{Cu}+\mathrm{Pb}+\mathrm{Ni}+\mathrm{Zn})$ was low, ranging from 0.2 to $0.5 \mu \mathrm{mol} / \mathrm{g}$ with the Ely Brook site being the highest and the Ompompanoosuc River site being the lowest. Simultaneously extracted mercury was below the detection limit $(0.2 \mathrm{mg} / \mathrm{kg} ; 0.001 \mu \mathrm{mol} / \mathrm{g})$.

$\mathrm{PEC}$ values are available for $\mathrm{As}, \mathrm{Cd}, \mathrm{Cr}, \mathrm{Cu}, \mathrm{Hg}, \mathrm{Ni}$, $\mathrm{Pb}$, and $\mathrm{Zn}$. In all cases for the background sites, including pond 1 , the concentrations of these elements were below these limits. HIs for these elements in sediments were above 1 at sites EB-1080M (1.1) and pond 1 (2), but below 1 at sites SB-3670M (0.6) and OR-24050M (0.4). The ( SEM-AVS)/ $\mathrm{f}_{\mathrm{OC}}$ values for all background stream-sediment samples ranged from -160 to $-60 \mu \mathrm{mol} / \mathrm{gOC}$, which were well within the noeffects range, and well below the onset of uncertain effects at $150 \mu \mathrm{mol} / \mathrm{gOC}$ (USEPA, 2005).

\section{Bioassay Results}

Toxicity testing of sediments was done only on samples from the stream reaches. Tests were conducted using Hyalella azteca for 28-day exposures and Chironomus dilutus for 12-day exposures. For both organisms, both survival and growth endpoints were measured (table 8). For reference sites EB-1080M, SB-3670M, and OR-24050M, H. azteca had acceptable survival at $93.8 \pm 1.8,93.8 \pm 4.6$, and $93.8 \pm$ 6.5 percent, respectively, during the 28 -day tests. Growth in the reference organisms was $3.24 \pm 0.05 \mathrm{~mm}$ for EB-1080M,

Table 6. Select chemistry results for sediments collected in August and September 2006 from the Ely Mine study area, Vershire, VT. -Continued

[wt. \%, weight percent; mg/kg, milligrams per kilogram; —, not determined; <, analyte not detected at the reporting level]

\begin{tabular}{|c|c|c|c|c|c|c|c|c|c|c|c|c|c|c|c|}
\hline $\begin{array}{c}\text { Stream } \\
\text { and } \\
\text { location }\end{array}$ & $\begin{array}{c}\text { Co } \\
(\mathrm{mg} / \mathrm{kg})\end{array}$ & $\begin{array}{c}\mathrm{Cr} \\
(\mathrm{mg} / \mathrm{kg})\end{array}$ & $\begin{array}{c}\text { Cu } \\
(\mathrm{mg} / \mathrm{kg})\end{array}$ & $\begin{array}{c}\mathrm{Hg} \\
(\mathrm{mg} / \mathrm{kg})\end{array}$ & $\begin{array}{c}\mathrm{Mn} \\
(\mathrm{mg} / \mathrm{kg})\end{array}$ & $\begin{array}{c}\text { Mo } \\
(\mathrm{mg} / \mathrm{kg})\end{array}$ & $\begin{array}{c}\mathrm{Ni} \\
(\mathrm{mg} / \mathrm{kg})\end{array}$ & $\begin{array}{c}\mathrm{Pb} \\
(\mathrm{mg} / \mathrm{kg})\end{array}$ & $\begin{array}{c}\mathrm{Sb} \\
(\mathrm{mg} / \mathrm{kg})\end{array}$ & $\begin{array}{c}\mathrm{Se} \\
(\mathrm{mg} / \mathrm{kg})\end{array}$ & $\begin{array}{c}\mathrm{Sr} \\
(\mathrm{mg} / \mathrm{kg})\end{array}$ & $\begin{array}{c}\mathrm{TI} \\
(\mathrm{mg} / \mathrm{kg})\end{array}$ & $\underset{(\mathrm{mg} / \mathrm{kg})}{\mathrm{U}}$ & $\begin{array}{c}V \\
(\mathrm{mg} / \mathrm{kg})\end{array}$ & $\begin{array}{c}\mathrm{Zn} \\
(\mathrm{mg} / \mathrm{kg})\end{array}$ \\
\hline $\mathrm{PEC}^{\mathrm{a}}$ & - & 111 & 149 & 1.06 & - & - & 48.6 & 128 & - & - & - & - & - & - & 459 \\
\hline \multicolumn{16}{|l|}{ Ely Brook } \\
\hline EB-1080M & 9.8 & 57 & 75.4 & $<0.02^{\mathrm{a}}$ & 780 & 0.41 & 16.5 & 24.8 & $<0.05$ & 0.3 & 133 & 0.3 & 0.9 & 73 & 56 \\
\hline EB-770M & 22.4 & 66 & 1160 & $<0.02$ & 2,090 & 2.11 & 20 & 14.6 & 0.06 & 4.1 & 111 & 0.3 & 1.4 & 96 & 122 \\
\hline $\begin{array}{l}\text { EB-90M-OBS } \\
\text { (overbank } \\
\text { sed.) }\end{array}$ & 13.3 & 89 & 1440 & 0.13 & 429 & 44.5 & 19.9 & 78.6 & 0.53 & 71.1 & 55.3 & 1.3 & 0.9 & 154 & 147 \\
\hline EB-20M & 15.1 & 67 & 3,700 & 0.03 & 1,020 & 16.2 & 15 & 38 & 1.15 & 35.2 & 92.2 & 0.3 & 0.8 & 112 & 196 \\
\hline \multicolumn{16}{|l|}{ Ely Ponds } \\
\hline EM-POND4 & 29.2 & 67 & 380 & 0.09 & 2,410 & 1.75 & 61.1 & 20.2 & 0.31 & 0.7 & 91.9 & 0.5 & 3.1 & 93 & 316 \\
\hline EM-POND5 & 78.3 & 70 & 3,540 & 0.09 & 1,430 & 2.54 & 56.8 & 23.5 & 0.97 & 1.3 & 76.5 & 0.5 & 5.7 & 79 & 507 \\
\hline EM-POND6 & 13.3 & 47 & 1,770 & 0.07 & 443 & 2.8 & 29.5 & 18.4 & 1.42 & 1.4 & 94.2 & 0.2 & 6.2 & 68 & 68 \\
\hline \multicolumn{16}{|c|}{ Schoolhouse Brook } \\
\hline SB-3670M & 4.8 & 24 & 10.4 & $<0.02$ & 501 & 0.28 & 13.2 & 11.2 & 0.15 & $<0.2$ & 202 & 0.2 & 0.8 & 40 & 32 \\
\hline SB-3260M & 11 & 40 & 1,390 & $<0.02$ & 1,120 & 7.26 & 11.5 & 17.9 & 2.39 & 9.8 & 164 & 0.2 & 1 & 62 & 93 \\
\hline SB-2400M & 10.8 & 23 & 167 & $<0.02$ & 504 & 2.29 & 11.4 & 10.5 & 0.65 & 1.8 & 193 & 0.2 & 0.8 & 43 & 54 \\
\hline SB-1360M & 9.6 & 28 & 198 & $<0.02$ & 864 & 2.53 & 11.6 & 11 & 1.8 & 1.5 & 206 & 0.2 & 0.8 & 48 & 66 \\
\hline SB-140M & 13.5 & 32 & 243 & $<0.02$ & 869 & 2.59 & 13.6 & 31.4 & 2.14 & 1.1 & 188 & 0.2 & 0.9 & 52 & 85 \\
\hline \multicolumn{16}{|c|}{ Ompompanoosuc River } \\
\hline
\end{tabular}

a Probable effects concentration (MacDonald and others, 2000). 
Table 7. Acid volatile sulfide (AVS) and simultaneously extractable metals (SEM) results for stream sediments from the Ely Mine study area, Vershire, VT.

$[\%$, percent; $\mathrm{mg} / \mathrm{kg}$, milligrams per kilogram; $\mu \mathrm{mol} / \mathrm{g}$, micromoles per gram]

\begin{tabular}{|c|c|c|c|c|c|c|c|c|c|c|c|c|}
\hline \multirow{2}{*}{$\begin{array}{l}\text { Stream and } \\
\text { location }\end{array}$} & \multirow{2}{*}{$\begin{array}{c}\text { Solids }^{a} \\
(\%)\end{array}$} & \multirow{2}{*}{$\begin{array}{c}\text { ASS }^{b} \\
(\mathrm{mg} / \mathrm{kg})\end{array}$} & \multirow{2}{*}{$\begin{array}{c}\text { AVS }^{c} \\
(\mu \mathrm{mol} / \mathrm{g})\end{array}$} & \multicolumn{8}{|c|}{ SEM $^{\mathrm{d}}$} & \multirow[b]{2}{*}{ SEM/AVS } \\
\hline & & & & $\begin{array}{c}\text { Cd } \\
(\mu \mathrm{mol} / \mathrm{g})\end{array}$ & $\begin{array}{c}\mathrm{Cu} \\
(\mu \mathrm{mol} / \mathrm{g})\end{array}$ & $\begin{array}{c}\mathrm{Fe} \\
(\mu \mathrm{mol} / \mathrm{g})\end{array}$ & $\begin{array}{c}\mathrm{Pb} \\
(\mu \mathrm{mol} / \mathrm{g})\end{array}$ & $\begin{array}{c}\mathrm{Mn} \\
(\mu \mathrm{mol} / \mathrm{g})\end{array}$ & $\begin{array}{c}\mathrm{Ni} \\
(\mu \mathrm{mol} / \mathrm{g})\end{array}$ & $\begin{array}{c}\mathrm{Zn} \\
(\mu \mathrm{mol} / \mathrm{g})\end{array}$ & $\begin{array}{c}\mathrm{Hg} \\
(\mu \mathrm{mol} / \mathrm{g})\end{array}$ & \\
\hline EB-1080M & 72.3 & $<10.9^{\mathrm{f}}$ & $<0.67$ & $<0.0012$ & 0.2 & 53.4 & 0.013 & 4.1 & 0.048 & 0.2 & $<0.0009$ & 0 \\
\hline EB-770M & 76.5 & $<10.5$ & $<0.64$ & 0.0012 & 5.4 & 48.3 & 0.011 & 2.1 & 0.036 & 0.3 & $<0.0008$ & 0 \\
\hline EB-600M & 79.4 & $<10.1$ & $<0.61$ & 0.0036 & 13.8 & 39.4 & 0.017 & 4.8 & 0.055 & 0.65 & $<0.00075$ & 0 \\
\hline \multicolumn{13}{|c|}{ Schoolhouse Brook } \\
\hline SB-3670M & 68.8 & $<11.6$ & $<0.71$ & $<0.0012$ & 0.024 & 33.3 & 0.013 & 3.6 & 0.039 & 0.12 & $<0.0009$ & 0 \\
\hline SB-2400M & 77.9 & $<10.3$ & $<0.64$ & $<0.0012$ & 0.99 & 39.8 & 0.0092 & 2.8 & 0.037 & 0.3 & $<0.0008$ & 0 \\
\hline SB-1360M & 74.9 & $<10.3$ & $<0.65$ & $<0.0012$ & 1.0 & 35.8 & 0.0087 & 3.2 & 0.044 & 0.3 & $<0.0008$ & 0 \\
\hline SB-140M & 73.5 & $<10.8$ & $<0.66$ & $<0.0012$ & 1.2 & 38.0 & 0.016 & 2.9 & 0.043 & 0.35 & $<0.00085$ & 0 \\
\hline
\end{tabular}

a Solids determined by Method IN623.

${ }^{\mathrm{b}}$ Acid soluble sulfide (total sulfide) detemined by SW846 Method 9030B/9034.

${ }^{\mathrm{c}}$ Acid volatile sulfide determined by SW846 Method 6010B.

${ }^{\mathrm{d}}$ Simultaneously extracteable metals detemined by SW846 Method 6010B(ICP-AES) for all metals except Hg, which was determined by Method 7471 A (cold-vapor atomic absorption).

${ }^{\text {e }} \mathrm{SEM} / \mathrm{AVS}$ is the sum of the concentrations of all metals divided by AVS, which in this study was less than the detection limit.

${ }^{\mathrm{f}}<$ : analyte was analyzed for but not detected above reporting limit.

Table 8. Results of 28-day toxicity tests with the amphipod Hyalella azteca and of 10-day toxicity tests with the midge Chironomus dilutus exposed to sediments from Ely Mine site, fall 2006.

[\%, percent; mm, millimeters; mg, milligrams; mean, mean value of eight replicates per sediment; std. err., standard error]

\begin{tabular}{|c|c|c|c|c|c|c|c|c|}
\hline \multirow{3}{*}{ Stream and location } & \multicolumn{4}{|c|}{ Amphipod, Hyalella azteca (28-day test) } & \multicolumn{4}{|c|}{ Midge, Chironomus dilutus (10-day test) } \\
\hline & \multicolumn{2}{|c|}{ Survival (\%) } & \multicolumn{2}{|c|}{ Total length (mm) } & \multicolumn{2}{|c|}{ Survival (\%) } & \multicolumn{2}{|c|}{ Ash-free dry wt. (mg) } \\
\hline & Mean & Std. err. & Mean & Std. err. & Mean & Std. err. & Mean & Std. err. \\
\hline \multicolumn{9}{|l|}{ Control } \\
\hline $\mathrm{FL}(\mathrm{C})^{\mathrm{a}}$ & 96.3 & 1.8 & 3.23 & 0.08 & 86.3 & 4.2 & 1.30 & 0.10 \\
\hline \multicolumn{9}{|l|}{ Ely Brook } \\
\hline EB-1080M (R) ${ }^{b}$ & 93.8 & 1.8 & 3.24 & 0.05 & 63.8 & 6.5 & 1.21 & 0.11 \\
\hline EB-770M & 68.8 & 5.8 & 2.45 & 0.06 & 61.3 & 4.8 & 0.61 & 0.11 \\
\hline EB-600M & 6.3 & 2.6 & 1.96 & 0.11 & 65.0 & 6.0 & 0.28 & 0.01 \\
\hline EB-90M & 91.3 & 4.0 & 3.39 & 0.06 & 72.5 & 4.5 & 1.73 & 0.37 \\
\hline \multicolumn{9}{|l|}{ Schoolhouse Brook } \\
\hline SB-3670M (R) & 93.8 & 4.6 & 3.31 & 0.06 & 76.3 & 5.3 & 1.00 & 0.05 \\
\hline SB-2400M & 52.5 & 7.5 & 2.43 & 0.11 & 80.0 & 4.2 & 0.78 & 0.04 \\
\hline SB-1360M & 64.3 & 6.1 & 2.53 & 0.11 & 62.5 & 5.9 & 1.28 & 0.08 \\
\hline SB-140M & 52.5 & 9.4 & 2.55 & 0.13 & 67.5 & 3.7 & 0.81 & 0.05 \\
\hline SB-140M (D) ${ }^{c}$ & 68.8 & 4.4 & 2.48 & 0.12 & 83.8 & 4.6 & 0.59 & 0.05 \\
\hline \multicolumn{9}{|l|}{ Ompompanoosuc River } \\
\hline OR-24050M (R) & 93.8 & 6.5 & 3.21 & 0.02 & 90.0 & 1.9 & 1.06 & 0.08 \\
\hline OR-23200M & 91.3 & 3.0 & 3.17 & 0.07 & 83.8 & 6.0 & 0.96 & 0.14 \\
\hline
\end{tabular}

${ }^{\mathrm{a}} \mathrm{C}$, indicates laboratory control sediment.

${ }^{\mathrm{b}} \mathrm{R}$, indicates local reference sites.

${ }^{\mathrm{c}} \mathrm{D}$, indicates lab duplicate. 
was $3.31 \pm 0.06 \mathrm{~mm}$ for SB-3670M, and was $3.21 \pm 0.02 \mathrm{~mm}$ for OR-24050M. In contrast, survival for $C$. dilutus was lower in EB-1080M (63.8 \pm 6.5 percent), SB-3670M (76.3 \pm 5.3 percent), and OR-24050M (90.0 \pm 1.9 percent). Growth, on an ash-free dry-weight basis, was $1.21 \pm 0.11 \mathrm{mg}$ for EB-1080M, $1.00 \pm 0.05 \mathrm{mg}$ for SB-3670M, and $1.06 \pm 0.08 \mathrm{mg}$ for OR-24050M.

\section{Ecological Indicators}

An evaluation of ecological indicators used to assess the relative ecosystem health across the sites indicated that background surface-water sites had well-established aquatic communities (figs. 8-10 and table 9). RTH invertebrate data for site EB-1080M reflected a good ecological structure and function. Invertebrate richness at site EB-1080M was 43 taxa, and abundance was 1,756 individuals. Depositional-targeted habitat (DTH) invertebrate data also reflected a good ecological structure and function. Invertebrate richness at site EB-1080M was 34 taxa, and abundance was 415 individuals. QMH invertebrate data for pond 1 also reflected a good ecological structure and function. Invertebrate richness at pond 1 was 59 taxa. Invertebrate abundance was high in pond 1 (1,950 individuals).

At the Schoolhouse Brook reference site (SB-3670M), RTH inverterbrate data reflected a good ecological structure and function. Invertebrate richness at site SB-3670M was 56 taxa, and abundance was 3,900 individuals. DTH invertebrate data also reflected a good ecological structure and function. Invertebrate richness at site SB-3670M was 30 taxa, and abundance was 161 individuals. The index of biotic integrity for fish was 42. Likewise, at the Ompompanoosuc River reference site (OR-24050M), RTH invertebrate data reflected a good ecological structure and function. Invertebrate richness at site OR-24050M was 84 taxa, and abundance was 2,864 individuals. DTH invertebrate data also reflected a good ecological structure and function. Invertebrate richness at site OR-24050M was 21 taxa, and abundance was 160 individuals. The index of biotic integrity for fish was 33 .

\section{Ely Brook Tributaries}

\section{Surface-Water Geochemistry}

Four tributaries flow into Ely Brook from the east and come in contact with mine waste or drain mine shafts directly (fig. 2). Each of the tributaries was analyzed individually to determine if there were significant differences in water chemistry based on previously published data (Argue and others, 2008). For this analysis, seep 13 was grouped with locations on tributary 1 , seeps $6,7,10,11$, and 14 were grouped with locations on tributary 2 , seeps $2-5,8,9,15-18,20$, and 21 were grouped with locations on tributary 3 , and seeps 1,12 , and 19 were grouped with locations on tributary 4 . Tributary 2 includes a series of ponds (ponds 1-6), which are the focus of this study and the focus of amphibian studies in the baseline ecological risk assessment (TechLaw, Inc., 2008). Chemical constituents for surface-water samples are summarized in table 4, and complete analyses are reported in appendix 6 .

\section{Field Parameters and Major Inorganic Constituents}

In general, the gross chemical properties of the tributary 2 pond-water samples display systematic degradation moving downstream from pond 1 , the reference site, through ponds 2 through 5 . The $\mathrm{pH}$ of tributary 2 dropped from 7.0
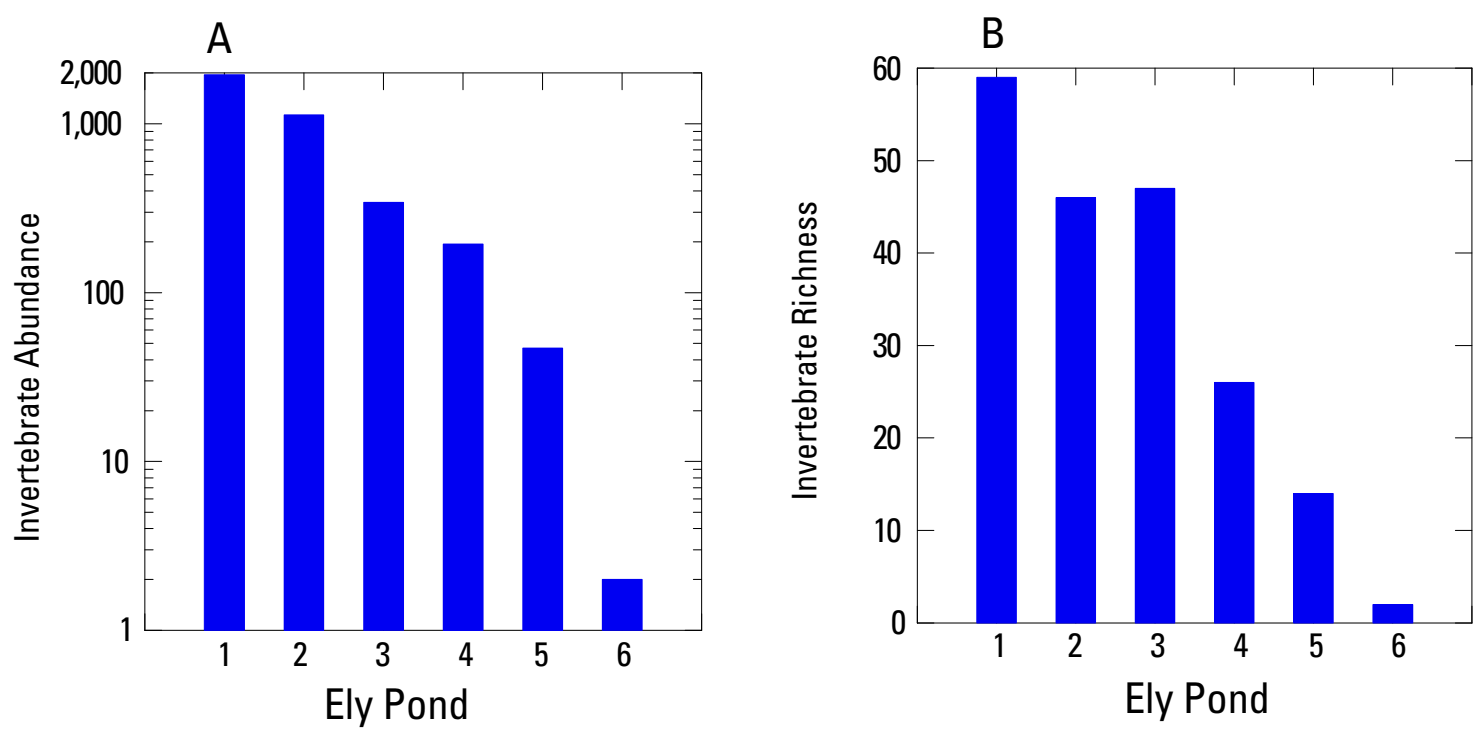

Figure 8. Qualitative multi-habitat $(\mathrm{OMH})$ invertebrate $(A)$ abundance and $(B)$ richness values among the Ely ponds, Vershire, VT. Pond 1 was farthest upgradient from sources of contamination and was used to represent background conditions. Locations are situated in the frames from up- to downgradient. 

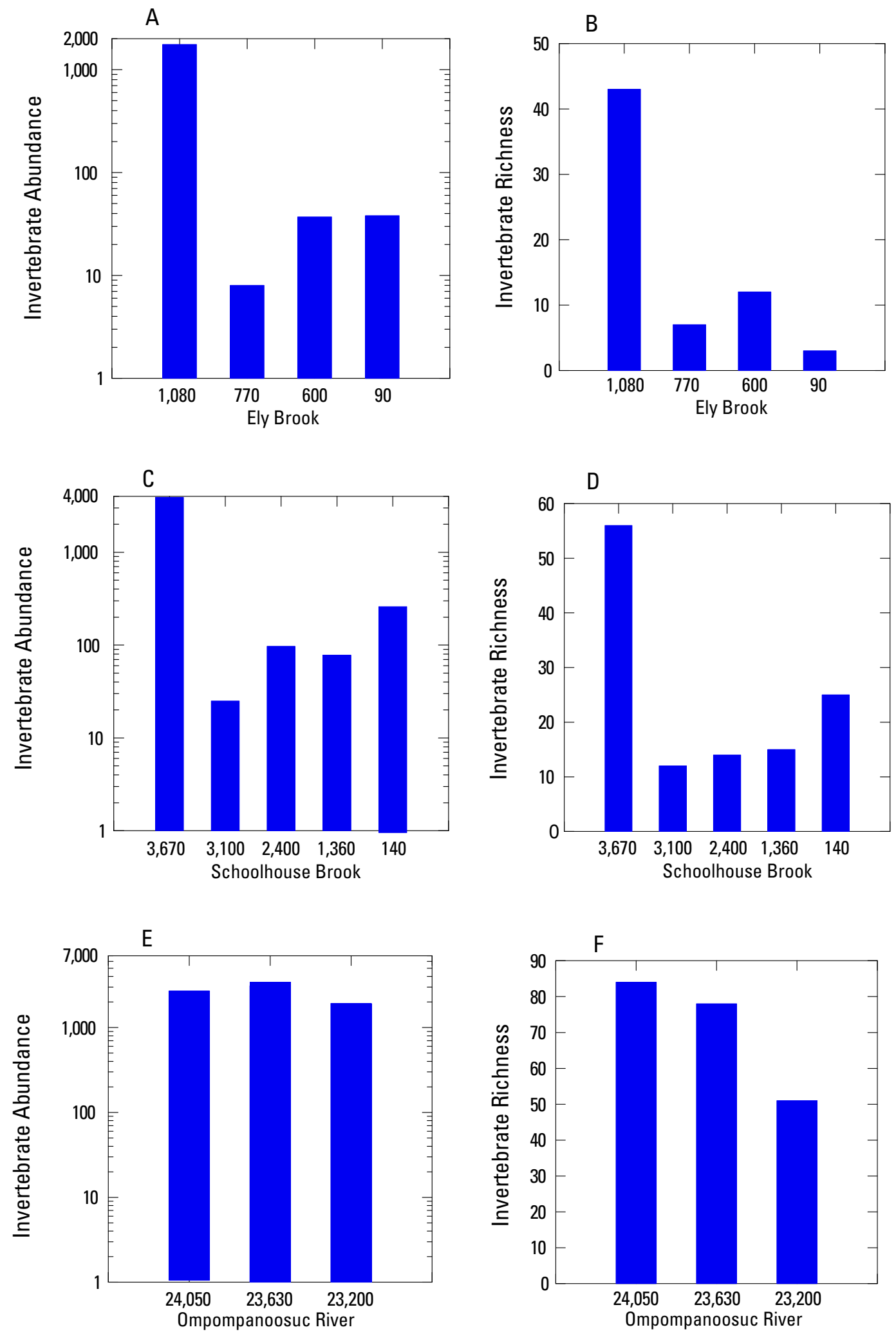

\section{River Meter and Reach}

Figure 9. Riffle-targeted habitat (RTH) invertebrate $(A)$ abundance and $(B)$ richness values in Ely Brook, (C) abundance and (D) richness values in Schoolhouse Brook, and (E) abundance and (F) richness values in the Ompompanoosuc River. The first location in each of the frames was farthest upgradient from sources of contamination and was used to represent background conditions for the stream. 

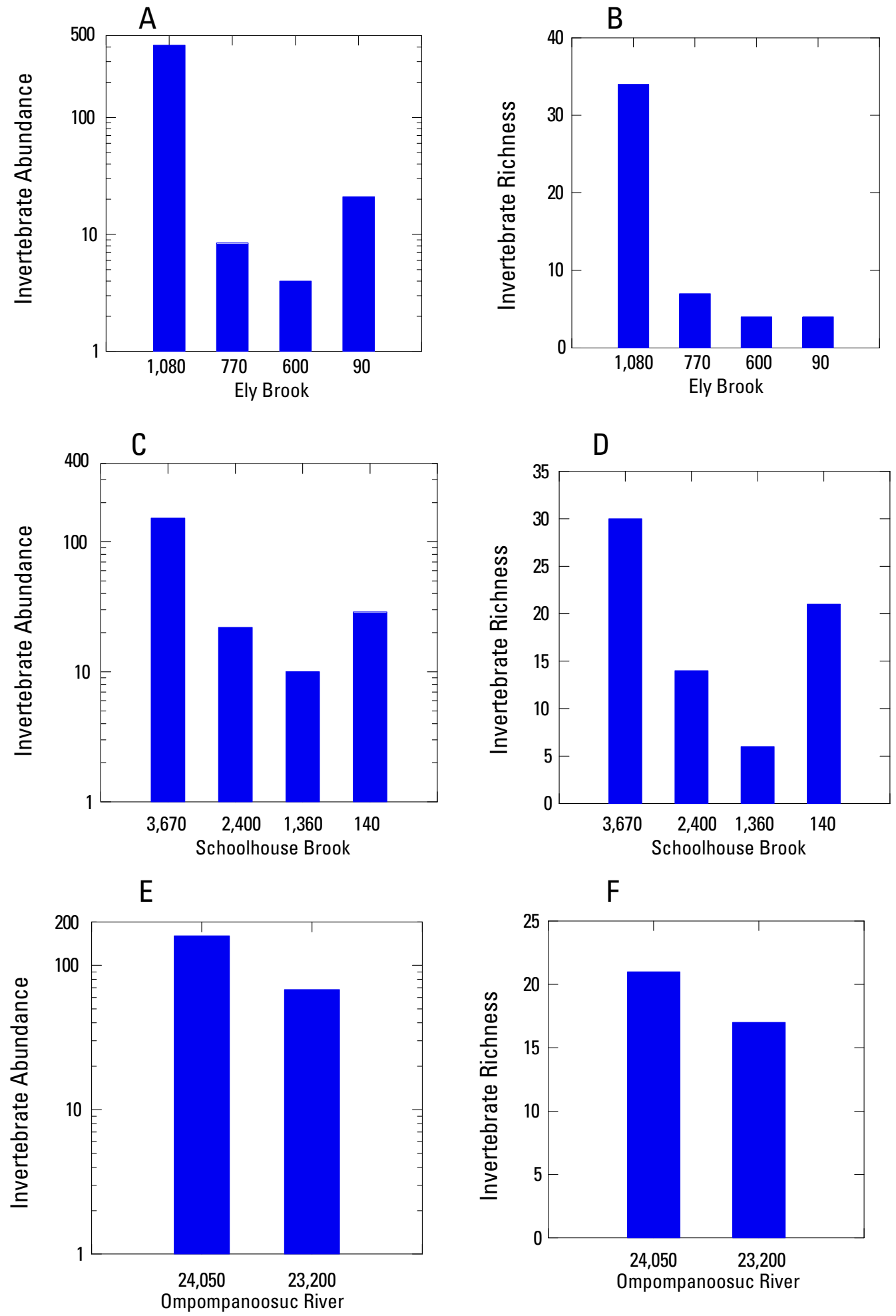

River Meter and Reach

Figure 10. Depositional-targeted habitat (DTH) invertebrate $(A)$ abundance and $(B)$ richness values in Ely Brook, (C) abundance and (D) richness values in Schoolhouse Brook, and (E) abundance and (F) richness values in the Ompompanoosuc River. The first location in each of the frames was farthest upgradient from sources of contamination and was used to represent background conditions for the stream. 
Table 9. Summary of selected invertebrate and fish data and the hazard index used for comparison of assemblage data to water quality at sampling locations in the Ely Mine study area, Vershire, VT. Refer to table 1 and figure 1 for site names, station numbers, and locations.

[RTH, riffle-targeted habitat; DTH, depositional-targeted habitat; QMH, qualitative multi-habitat; IBI, index of biotic integrity; SW, surface water; PW, pore water]

\begin{tabular}{|c|c|c|c|c|c|c|c|c|c|}
\hline \multirow{3}{*}{$\begin{array}{l}\text { Stream and } \\
\text { location }\end{array}$} & \multicolumn{6}{|c|}{ Invertebrate assemblage metrics } & \multirow{3}{*}{$\begin{array}{c}\text { Fish } \\
\text { assemblage } \\
\mid \mathrm{IB|^{ \textrm {a } }}\end{array}$} & \multicolumn{2}{|c|}{ Hazard index } \\
\hline & \multicolumn{2}{|c|}{ RTH } & \multicolumn{2}{|c|}{ DTH } & \multicolumn{2}{|c|}{ OMH } & & \multirow{2}{*}{ SW } & \multirow{2}{*}{ PW } \\
\hline & Abundance & Richness & Abundance & Richness & Abundance & Richness & & & \\
\hline \multicolumn{10}{|l|}{ Ely Brook } \\
\hline EB-1080M & 1,756 & 43 & 415 & 34 & & & & 0.5 & 0.6 \\
\hline EB-770M & 8 & 7 & 8 & 7 & & & & 144.0 & 6.8 \\
\hline EB-600M & 37 & 12 & 4 & 4 & & & & 76.4 & 9.7 \\
\hline EB-90M & 38 & 3 & 21 & 4 & & & & 199.3 & 270.3 \\
\hline \multicolumn{10}{|l|}{ Ely Ponds } \\
\hline Ely Pond 1 & & & & & 1,950 & 59 & & .9 & \\
\hline Ely Pond 2 & & & & & 1,128 & 46 & & 1.6 & \\
\hline Ely Pond 3 & & & & & 342 & 47 & & .7 & \\
\hline Ely Pond 4 & & & & & 194 & 26 & & 4.0 & \\
\hline Ely Pond 5 & & & & & 47 & 14 & & 92.0 & \\
\hline Ely Pond 6 & & & & & 2 & 2 & & 240.0 & \\
\hline \multicolumn{10}{|c|}{ Schoolhouse Brook } \\
\hline SB-3670M & 3,900 & 56 & 161 & 30 & & & 42 & .0 & $<0.5$ \\
\hline SB-3100M & 25 & 12 & & & & & 9 & 3.9 & \\
\hline SB-2400M & 97 & 14 & 22 & 14 & & & 9 & 2.4 & .7 \\
\hline SB-1360M & 78 & 15 & 10 & 6 & & & 18 & 2.3 & 2.7 \\
\hline SB-140M & 278 & 25 & 29 & 21 & & & 29 & 2.4 & .7 \\
\hline \multicolumn{10}{|c|}{ Ompompanoosuc River } \\
\hline OR-24050M & 2,864 & 84 & 160 & 21 & & & 33 & .2 & .0 \\
\hline OR-23630M & 3,124 & 78 & & & & & 33 & .4 & \\
\hline OR-23200M & 1,924 & 51 & 68 & 17 & & & 33 & 1.2 & .6 \\
\hline
\end{tabular}

${ }^{a}$ Index of biotic integrity values were compiled by the Vermont Department of Environmental Conservation (2008).

${ }^{\mathrm{b}}$ The hazard index for surface water was compared with RTH and QMH metrics and fish index of biotic integrity values; the hazard index for pore water was compared with DTH metrics.

in the reference pond to 6.5 in pond 5; pond 6 had a pH of 4.7 (fig. 5). The specific conductance concomitantly increased from $51 \mu \mathrm{S} / \mathrm{cm}$ in the reference pond to $117 \mu \mathrm{S} / \mathrm{cm}$ in pond 5; the specific conductance of pond 6 was $206 \mu \mathrm{S} / \mathrm{cm}$ (fig. 5). Calcium was the dominant dissolved cation and increased from 5.8 to $18.6 \mathrm{mg} / \mathrm{L}$. Magnesium (1.1 to $4.2 \mathrm{mg} / \mathrm{L}$ ), Na (1.2 to $1.6 \mathrm{mg} / \mathrm{L}$ ), and $\mathrm{K}$ ( 1.7 to $2.5 \mathrm{mg} / \mathrm{L}$ ) occurred in subequal proportions and were lowest in the reference site. Silica $\left(\mathrm{SiO}_{2}\right)$ ranged from 2.2 to $14.8 \mathrm{mg} / \mathrm{L}$ and likewise was lowest in the reference pond. Alkalinity was the dominant anionic species (19 to $30 \mathrm{mg} / \mathrm{L}$ $\mathrm{CaCO}_{3}$ equivalent) in ponds 1 through 4, but sulfate was dominant in ponds 5 and 6 , which undoubtedly reflects increasing contributions of acid-mine drainage (fig. 6). Hardness values increased from $18.8 \mathrm{mg} / \mathrm{L} \mathrm{CaCO}_{3}$ equivalent in the reference pond to $42.5 \mathrm{mg} / \mathrm{L} \mathrm{CaCO}_{3}$ equivalent in pond 5 (fig. 6).

\section{Iron, Aluminum, and Manganese}

Iron, aluminum, and manganese showed crude increases from the reference pond moving downstream (fig. 7). Dissolved iron increased from $66 \mu \mathrm{g} / \mathrm{L}$ to $565 \mu \mathrm{g} / \mathrm{L}$ in pond 6 , although the concentration in pond 5 was below detection $(<20 \mu \mathrm{g} / \mathrm{L})$. Dissolved aluminum concentrations were $15.8 \mu \mathrm{g} / \mathrm{L}$ in the reference pond and $1,410 \mu \mathrm{g} / \mathrm{L}$ in pond 6 with values ranging between 5.5 and $10.1 \mu \mathrm{g} / \mathrm{L}$ between these two ponds. Dissolved manganese concentrations increased from $2.7 \mu \mathrm{g} / \mathrm{L}$ in the reference pond to $564 \mu \mathrm{g} / \mathrm{L}$ in pond 6 .

\section{Minor and Trace Inorganic Elements}

The dissolved concentrations of the minor and trace elements that typify the Ely Mine deposit $(\mathrm{Cd}, \mathrm{Co}, \mathrm{Cu}, \mathrm{Ni}$, and $\mathrm{Zn}$ ) generally increased moving downstream through the ponds (fig. 7). The concentrations of all other minor and trace elements tended to be low, near their respective detection limits. Dissolved Ag, As, Cr, Se, Tl, and V concentrations were all below their detection limits. Dissolved Ba concentrations ranged from 9.6 to $18.6 \mu \mathrm{g} / \mathrm{L}$, dissolved Be from $<0.05$ to $0.2 \mu \mathrm{g} / \mathrm{L}$, dissolved $\mathrm{Pb}$ from $<0.05$ to $0.4 \mu \mathrm{g} / \mathrm{L}$, dissolved $\mathrm{Sb}$ from $<0.3$ to $0.62 \mu \mathrm{g} / \mathrm{L}$, dissolved $\mathrm{Sr}$ from 20.5 to $50.4 \mu \mathrm{g} / \mathrm{L}$, and dissolved $\mathrm{U}$ from $<0.1$ to $0.2 \mu \mathrm{g} / \mathrm{L}$. 
The metals associated with the deposit have distinctly higher dissolved concentrations in the ponds. Dissolved Cd concentrations ranged from $<0.02$ to $2.28 \mu \mathrm{g} / \mathrm{L}$, dissolved Co from 0.03 to $46.3 \mu \mathrm{g} / \mathrm{L}$, dissolved $\mathrm{Cu}$ from 1.1 to $1,380 \mu \mathrm{g} / \mathrm{L}$, dissolved Ni from $<0.4$ to $16.7 \mu \mathrm{g} / \mathrm{L}$, and dissolved $\mathrm{Zn}$ from 2.3 to $325 \mu \mathrm{g} / \mathrm{L}$. HIs $(\mathrm{Cd}+\mathrm{Cu}+\mathrm{Ni}+\mathrm{Pb}+\mathrm{Zn})$ comparing surface-water quality at these sites to hardness-based chronic ambient water-quality standards ranged from 0.82 in the reference pond up to 244 in pond 6 (table 10). HIs generally increased moving downstream and indicate significant potential for impairment in ponds 5 and 6 , and possibly 4 .

\section{Dissolved Organic Carbon and Nutrients}

DOC concentrations throughout the study area ranged from 1.1 to $3.5 \mathrm{mg} / \mathrm{L}$ with Ely pond 1 having the highest values. Nutrients were generally low throughout the study area.
Total dissolved nitrogen ranged from 0.10 to $0.46 \mathrm{mg} / \mathrm{L}$, and total dissolved phosphorus ranged from 0.003 to $0.036 \mathrm{mg} / \mathrm{L}$.

Comparisons with Ambient Water-Quality Criteria and Relations among Reaches

The four tributaries that flow into Ely Brook from the east all come in contact with mine waste or drain mine shafts directly (fig. 2). Concentrations of elements greater than AWQC were observed in tributary 1 for $\mathrm{Al}, \mathrm{Ba}, \mathrm{Cd}, \mathrm{Co}, \mathrm{Cu}$, $\mathrm{Mn}$, and $\mathrm{Zn}$; in tributary 2 for $\mathrm{Al}, \mathrm{Ba}, \mathrm{Cd}, \mathrm{Cr}, \mathrm{Co}, \mathrm{Cu}, \mathrm{Fe}$, $\mathrm{Mn}, \mathrm{Ni}, \mathrm{U}$, and $\mathrm{Zn}$; in tributary 3 for $\mathrm{Al}, \mathrm{Ba}, \mathrm{Cd}, \mathrm{Cr}, \mathrm{Co}, \mathrm{Cu}$, $\mathrm{Fe}, \mathrm{Pb}, \mathrm{Mn}, \mathrm{Se}, \mathrm{U}$, and $\mathrm{Zn}$; and in tributary 4 for $\mathrm{Al}, \mathrm{Ba}, \mathrm{Cd}$, $\mathrm{Cr}, \mathrm{Co}, \mathrm{Cu}, \mathrm{Fe}, \mathrm{Mn}, \mathrm{Ni}, \mathrm{Se}, \mathrm{U}$, and $\mathrm{Zn}$ (fig. 11, appendix 2). Median concentrations of most elements in surface waters of tributary 1 were similar to or less than background conditions with the exception of copper, which was higher (fig. 11).

Table 10. Summary of the hazard quotient and hazard index for select constituents in waters and stream sediments at sampling locations in the Ely Mine study area, Vershire, VT, August 21 to 23, 2006. Refer to table 1 and figure 1 for site names, station numbers, and locations.

[SW, surface water; PW, in situ pore water; SED, sediment; - , not determined because analyte concentration is below the reporting level]

\begin{tabular}{|c|c|c|c|c|c|c|c|c|c|c|c|c|c|c|c|c|c|c|}
\hline \multirow{2}{*}{$\begin{array}{l}\text { Stream and } \\
\text { location }\end{array}$} & \multicolumn{15}{|c|}{ Hazard quotient } & \multicolumn{3}{|c|}{ Hazard index } \\
\hline & SW & PW & SED & sw & PW & SED & SW & PW & SED & SW & PW & SED & SW & PW & SED & sw & PW & SED \\
\hline
\end{tabular}

Ely Brook

\begin{tabular}{|c|c|c|c|c|c|c|c|c|c|c|c|c|c|c|c|c|c|}
\hline EB-1080M & - & - & 0.0 & 0.3 & 0.6 & 0.5 & 0.0 & 0.0 & 0.3 & - & 0.1 & 0.2 & 0.1 & 0.6 & 0.1 & 0.4 & 1.3 \\
\hline EB-770M & 5.8 & 2.0 & 0.1 & 153 & 6.0 & 7.8 & 0.4 & 0.2 & 0.4 & 0.07 & 0.2 & 0.1 & 1.6 & 0.8 & 0.3 & 161 & 9.2 \\
\hline EB-600M & 3.3 & 2.1 & 0.2 & 45 & 9.4 & 18 & 0.2 & 0.2 & 0.5 & 0.05 & 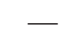 & 1.4 & 1.0 & 0.4 & 0.4 & 50 & 12 \\
\hline
\end{tabular}

Ely Ponds

$\begin{array}{lccccccccccccc}\text { Ely Pond 1 } & - & 0.2 & 0.5 & 0.6 & - & 0.7 & 0.23 & 0.2 & 0.1 & 0.3 & 0.8 & 2 \\ \text { Ely Pond 2 } & - & 0.3 & 1.1 & 0.6 & 0.0 & 0.9 & 0.16 & 0.2 & 0.3 & 0.3 & 1.6 & 2.3 \\ \text { Ely Pond 3 } & - & 0.2 & 0.6 & 0.5 & 0.0 & 0.8 & 0.17 & 0.3 & 0.1 & 0.3 & 0.9 & 2.1 \\ \text { Ely Pond 4 } & 0.8 & 0.5 & 4.2 & 2.6 & 0.1 & 1.3 & 0.15 & 0.2 & 0.3 & 0.7 & 5.6 & 5.3 \\ \text { Ely Pond 5 } & 7.5 & 0.8 & 103 & 24 & 0.3 & 1.2 & - & 0.2 & 2.5 & 1.1 & 113 & 27 \\ \text { Ely Pond 6 } & 12.7 & 0.0 & 227 & 12 & 0.5 & 0.6 & 0.26 & 0.1 & 4.0 & 0.1244\end{array}$

Schoolhouse Brook

\begin{tabular}{|c|c|c|c|c|c|c|c|c|c|c|c|c|c|c|c|c|c|c|}
\hline SB-3670M & - & - & - & - & - & 0.1 & - & - & 0.3 & 0.02 & 0.0 & 0.1 & 0.0 & 0.0 & 0.1 & 0.0 & 0 & 0.6 \\
\hline SB-3100M & 0.5 & & & 5.0 & & & 0.0 & & & 0.03 & & & 0.1 & & & 5.6 & & \\
\hline SB-2400M & 0.3 & 0.3 & 0.0 & 2.8 & 0.7 & 1.1 & 0.0 & 0.0 & 0.2 & - & - & 0.1 & 0.1 & 0.0 & 0.1 & 3.2 & 1 & 1.5 \\
\hline SB-1360M & 0.3 & 0.2 & 0.0 & 2.6 & 1.1 & 1.3 & 0.0 & 0.0 & 0.2 & - & 0.1 & 0.1 & 0.2 & 0.1 & 0.1 & 3.1 & 1.5 & 1.7 \\
\hline SB-140M & 0.2 & 0.2 & 0.0 & 2.6 & 0.6 & 1.6 & 0.0 & 0.0 & 0.3 & 0.05 & 0.1 & 0.2 & 0.1 & 0.0 & 0.2 & 3.0 & 0.9 & 2.3 \\
\hline OR-23630M & 0.1 & & & 0.4 & & & - & & & 0.03 & & & 0.1 & & & 0.6 & & \\
\hline OR-23200M & 0.4 & 0.3 & 0.0 & 1.1 & 0.5 & 0.5 & 0.0 & 0.0 & 0.2 & 0.09 & 0.1 & 0.1 & 0.1 & 0.0 & 0.1 & 1.7 & 0.9 & 0.9 \\
\hline
\end{tabular}



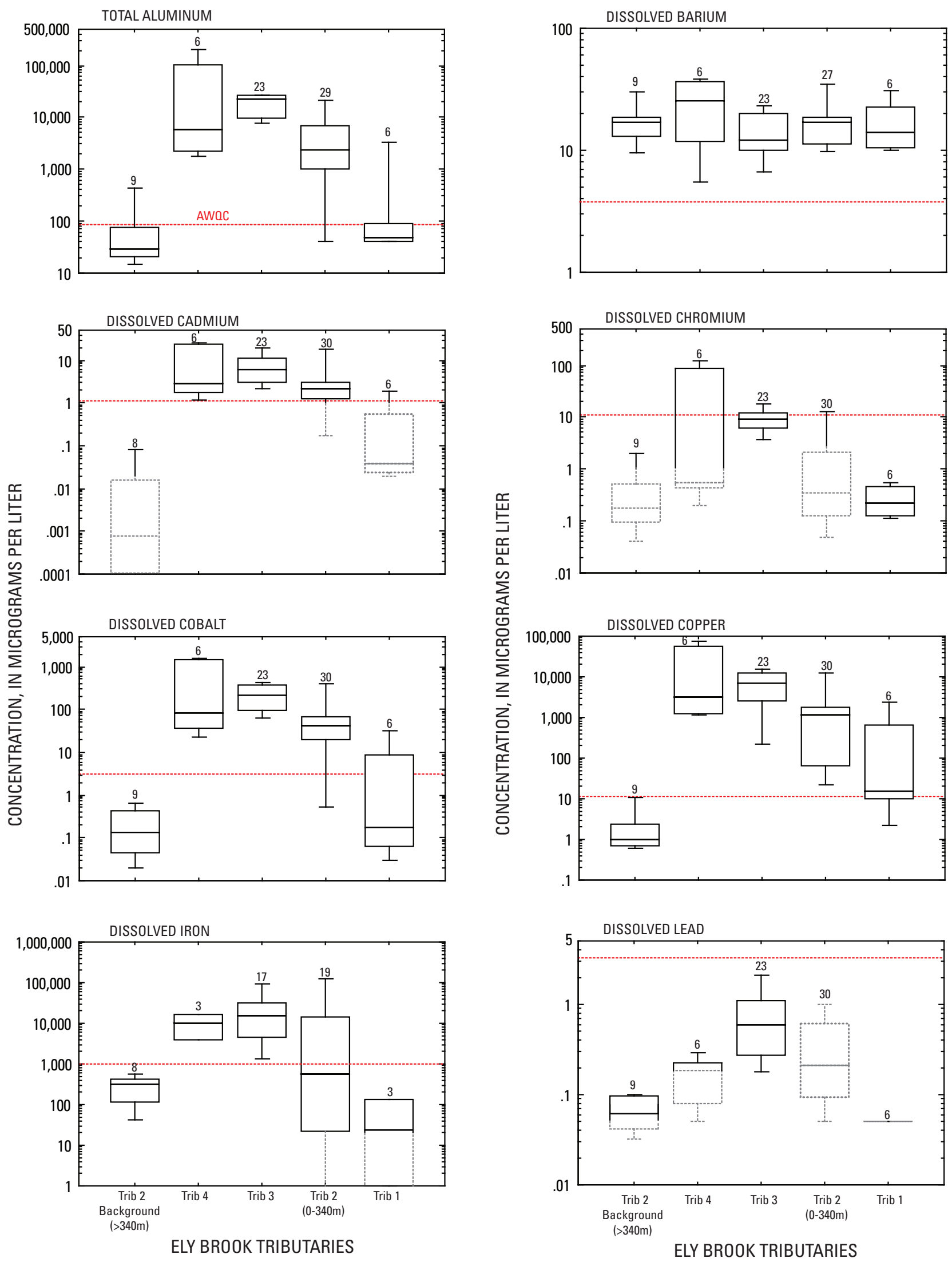

Figure 11. Select constituent concentrations in surface waters among four tributaries to Ely Brook at the Ely Mine Superfund site, Vershire, VT. Data are from this study and Argue and others (2008). 

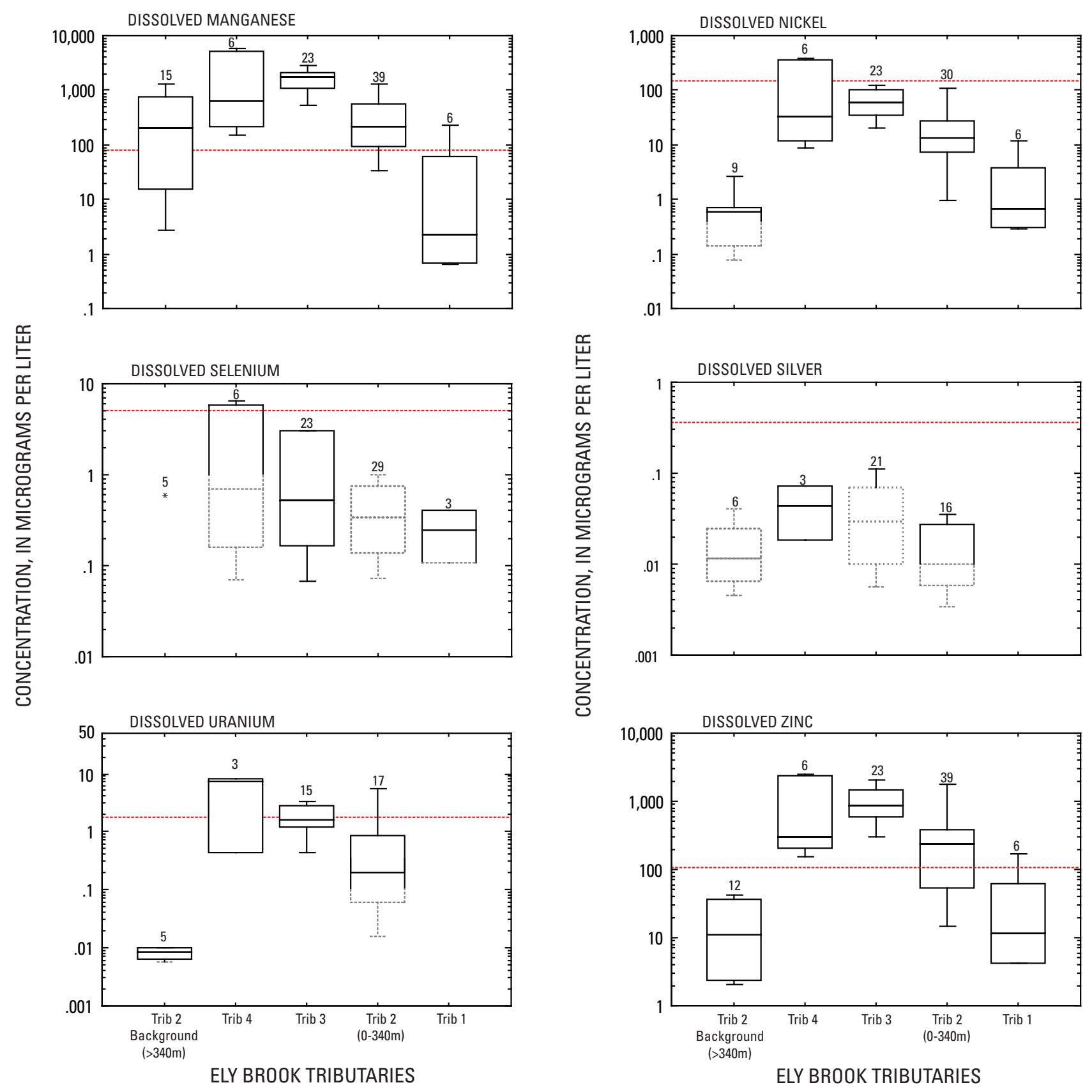

\section{EXPLANATION}

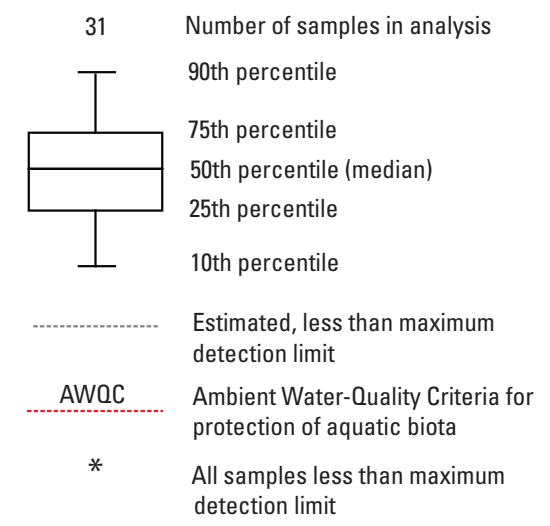

Figure 11. Select constituent concentrations in surface waters among four tributaries to Ely Brook at the Ely Mine Superfund site, Vershire, VT. Data are from this study and Argue and others (2008).—Continued 
Concentrations of most elements in surface waters of tributaries 2, 3, and 4 were greater than background conditions by 1 to 4 orders of magnitude (fig. 11) with the exceptions being $\mathrm{Ba}$, which was similar among all tributaries and background conditions (rho > 0.05), $\mathrm{Cr}, \mathrm{Fe}, \mathrm{Mn}, \mathrm{Se}$, and $\mathrm{Ag}$, which were similar between tributary 2 and background conditions (rho > 0.05), and Se and Ag, which were similar between tributary 3 and background conditions (rho $>0.05$ ).

Statistically significant differences were observed among tributaries for some trace-element concentrations. Most trace-element concentrations in tributary 1 were less than and significantly different from tributaries 2,3 , and $4($ rho $<0.05)$. However, $\mathrm{Al}$ and $\mathrm{Cu}$ concentrations were similar ( $\mathrm{rho}>0.05$ ) between tributaries 1 and 2. Concentrations of $\mathrm{Al}, \mathrm{Cr}, \mathrm{Co}, \mathrm{Fe}$, $\mathrm{Mn}, \mathrm{Ni}, \mathrm{U}$, and $\mathrm{Zn}$ in tributary 2 were generally less than and significantly different from tributary 3 (rho $<0.05$ ). Concentrations of trace elements were similar between tributaries 2 and 4 $($ rho $>0.05)$ and between tributaries 3 and $4($ rho $>0.05)$ with the exception being lead in tributary 3 , which was generally greater than and significantly different from tributary $4($ rho $<0.05)$.

\section{Sediment Geochemistry}

The major-element geochemistry of the pond sediments reflects their siliciclastic constituents. Chemical constituents for sediment samples are summarized in table 6, and complete analyses are reported in appendix 8. Aluminum concentrations ranged from 5.5 to 11.1 weight percent in the pond sediments, and was 6.7 weight percent in the reference pond, pond 1 . $\mathrm{Na}, \mathrm{K}, \mathrm{Ca}$, and $\mathrm{Mg}$ all ranged from 0.7 to 1.9 weight percent. Iron concentrations ranged from 3.5 to 5.8 weight percent in the pond sediments, and was 4.4 weight percent in the sediments of pond 1. Manganese concentrations were low, ranging between 443 and $3,130 \mathrm{mg} / \mathrm{kg}$. Carbonate carbon concentrations are uniformly low, between 0.04 and 0.07 weight percent carbon, whereas total organic carbon concentrations in the pond sediments were high ranging from 6.5 to 10.4 weight percent. Total sulfur concentrations ranged between 0.34 and 0.93 weight percent.

The concentrations of trace elements were variable, with the exception of copper, which had a systematic increase downstream through the ponds from 81.7 to $3,540 \mathrm{mg} / \mathrm{kg}$. The ranges in concentrations in pond sediments for $\mathrm{Ag}(<1 \mathrm{mg} / \mathrm{kg})$, As $(<1-7 \mathrm{mg} / \mathrm{kg}), \mathrm{Cd}(0.2-2.5 \mathrm{mg} / \mathrm{kg})$, Co $(13.3-78.3 \mathrm{mg} / \mathrm{kg})$, $\mathrm{Cr}(47-130 \mathrm{mg} / \mathrm{kg}), \mathrm{Hg}(0.07-0.15 \mathrm{mg} / \mathrm{kg})$, Mo (0.63$2.58 \mathrm{mg} / \mathrm{kg}), \mathrm{Ni}(29.5-61.1 \mathrm{mg} / \mathrm{kg}), \mathrm{Pb}(18.4-43.7 \mathrm{mg} / \mathrm{kg}), \mathrm{Sb}$ $(<0.05-1.42 \mathrm{mg} / \mathrm{kg})$, Se $(0.7-1.4 \mathrm{mg} / \mathrm{kg}), \mathrm{U}(2.3-6.2 \mathrm{mg} / \mathrm{kg})$, $\mathrm{V}(68-163 \mathrm{mg} / \mathrm{kg})$, and $\mathrm{Zn}(68-507 \mathrm{mg} / \mathrm{kg})$ did not correlate with distance downstream from the reference pond. None of the ponds exceeded the $\mathrm{PEC}$ values for $\mathrm{As}, \mathrm{Cd}, \mathrm{Hg}, \mathrm{Pb}$, or $\mathrm{Zn}$. Pond 2 exceeded the Cr PEC, ponds 4 and 5 exceeded both the $\mathrm{Cu}$ and Ni PECs, and pond 6 only exceeded the Cu PEC. HIs for $\mathrm{Cd}, \mathrm{Cu}, \mathrm{Ni}, \mathrm{Pb}$, and $\mathrm{Zn}$ in pond sediments were above 1 at all sites (table 10). The values generally increase downstream from 2 in the reference pond to 27 in pond 5, and then the values drop to 13 in pond 6 .

\section{Ecological Indicators}

An evaluation of the QMH invertebrate data sampled within the ponds indicated that impairment sequentially increased from pond 1 to 6 , but that impairment was most severe beginning at pond 4 , and continued downgradient from that location (fig. 8; table 9). For example, invertebrate richness at pond 1 was 59 taxa, which decreased to 47 at pond 3 (20 percent loss), but further decreased to 26 at pond 4 (56 percent loss). Although QMH-based invertebrate abundance is typically not considered a definitive metric of condition, it can often be used to indicate a relative degree of ecosystem function when sampling effort is standardized. Invertebrate abundance was highest at pond 1 (1,950 individuals) but was reduced an order of magnitude at pond 4 (194 individuals) and three orders of magnitude by pond 6 ( 2 individuals). Decreases in the values of abundance and richness were closely associated with the increase in surface-water metal concentrations, as characterized by the HIs derived for the sites (fig. 12; table 9). The in situ amphibian embryo-larval toxicity testing done in 2007 provides additional insights into the ecological health of the ponds. For these tests, wood frog egg masses were collected from an offsite reference pond and placed within enclosures in Ely Mine ponds 1, 4, and 5. Ponds 4 and 5 showed high mortality in recently hatched larvae, and pond 4 also had decreased larval survival over time (TechLaw, Inc., 2008).

\section{Ely Brook}

\section{Surface-Water Geochemistry}

Four sites were sampled in Ely Brook in August 2006, one of which was upstream of mine-impacted drainage and was also discussed in the background conditions section (EB-1080M). The three other Ely Brook sites include site EB-770M located $10 \mathrm{~m}$ downstream of Ely Brook tributary 4, site EB-600M located $200 \mathrm{~m}$ downstream of Ely Brook tributary 4 and upstream of Ely Brook tributary 2, and site EB-90M located downstream of Ely Brook tributary 1 and upstream of the confluence with Schoolhouse Brook. Data from these sites from this study will be used to examine downstream variations in chemistry. Chemical constituents for surface-water samples are summarized in table 4 , and complete analyses are reported in appendix 6.

\section{Field Parameters and Major Inorganic Constituents}

The $\mathrm{pH}$ of Ely Brook fluctuated from 7.2 at background site EB-1080M to 6.3 at EB-770M to 7.0 at EB-600M and then decreased drastically to 3.2 at EB-90M. In contrast to $\mathrm{pH}$, specific conductance increased from $87 \mu \mathrm{S} / \mathrm{cm}$ (EB-1080M) to $149 \mu \mathrm{S} / \mathrm{cm}$ (EB-770M), then decreased to $123 \mu \mathrm{S} / \mathrm{cm}$ (EB-600M), and then increased drastically to $447 \mu \mathrm{S} / \mathrm{cm}$ (EB-90M) (fig. 5). The major dissolved cations (Ca, K, Mg, $\mathrm{Na}, \mathrm{SiO}_{2}$ ) and hardness fluctuated in the same manner as the specific conductance. Calcium (13.4 to $21.1 \mathrm{mg} / \mathrm{L}$ ) and $\mathrm{SiO}_{2}$ ( 9.1 to $33.1 \mathrm{mg} / \mathrm{L}$ ) were the dominant dissolved cations and occurred in subequal proportions; other major cations include 

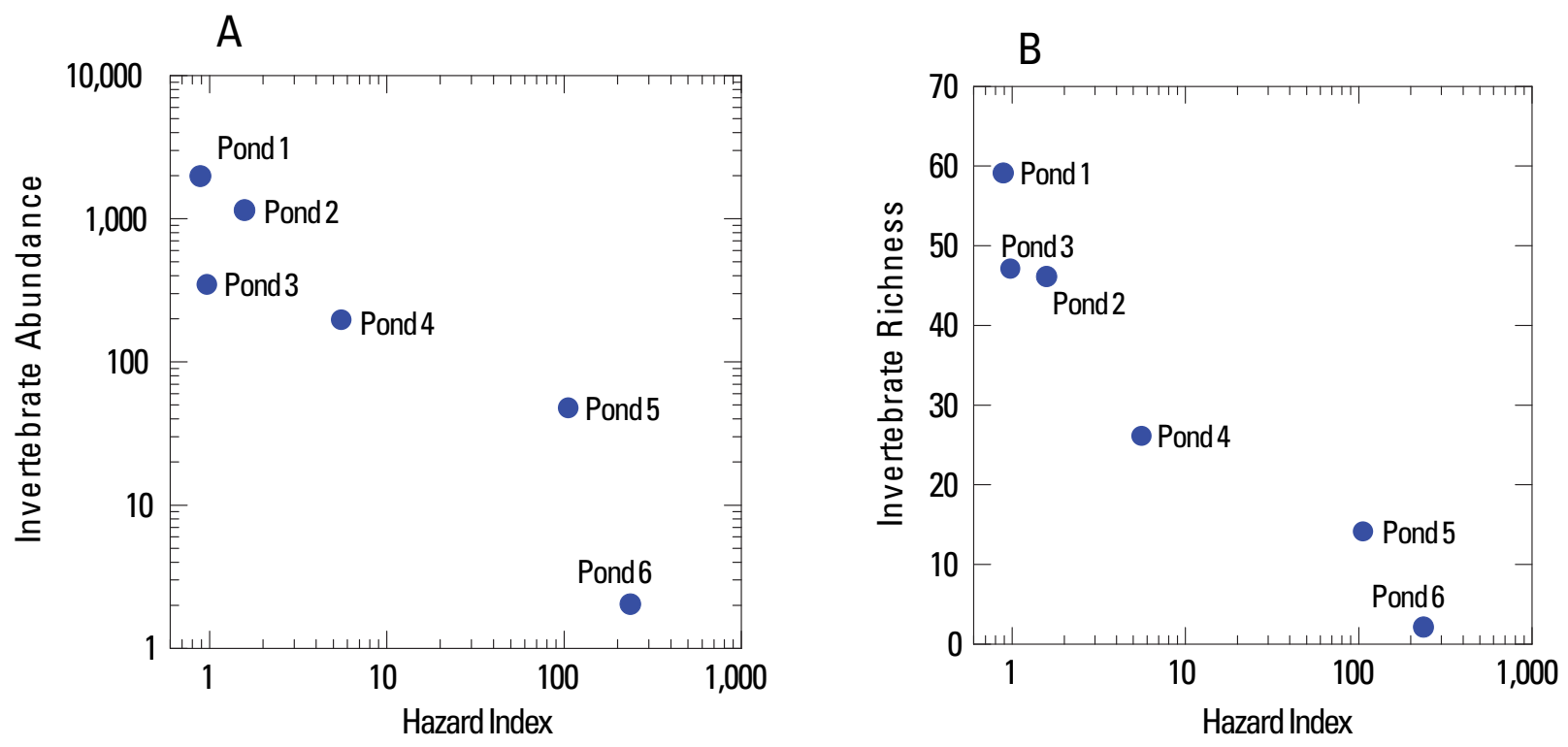

\section{Explanation}

Pond6 Sample location and identifier

Figure 12. Qualitative multi-habitat $(\mathrm{OMH})$ invertebrate $(A)$ abundance and $(B)$ richness values relative to the gradient in hazard index values derived from trace metal concentration in surface-waters from the Ely ponds, Vershire, VT.

$\mathrm{K}$ (1.69 to $3.42 \mathrm{mg} / \mathrm{L}), \mathrm{Mg}$ (1.18 to $5.54 \mathrm{mg} / \mathrm{L})$, and $\mathrm{Na}(1.12$ to $2.3 \mathrm{mg} / \mathrm{L})$. Alkalinity was the dominant anionic species in the background conditions sample (EB-1080M) with a concentration of $41 \mathrm{mg} / \mathrm{L} \mathrm{CaCO}_{3}$ (fig. 6). In contrast, sulfate dominated in the mine-impacted Ely Brook samples (EB-770M to EB-90M) with concentrations ranging from 36 to $143 \mathrm{mg} / \mathrm{L}$ (fig. 6). In comparison, chloride concentrations only reached $2.6 \mathrm{mg} / \mathrm{L}$. Previous reports found similar results (Seal and others, 2001; Holmes and others, 2002; Argue and others, 2008).

\section{Iron, Aluminum, and Manganese}

The concentrations of dissolved Mn (92.8 to $217 \mu \mathrm{g} / \mathrm{L}$ ) were considerably higher than the concentrations of dissolved $\mathrm{Al}(3.4$ to $25.1 \mu \mathrm{g} / \mathrm{L})$ and $\mathrm{Fe}(<20$ to $22 \mu \mathrm{g} / \mathrm{L})$ in the three most upstream Ely Brook surface waters (EB-1080M, EB770M, and EB-600M) (fig. 7). In contrast, Fe $(6,370 \mu \mathrm{g} / \mathrm{L})$ and $\mathrm{Al}(4,190 \mu \mathrm{g} / \mathrm{L})$ dominated at EB-90M in comparison to Mn $(521 \mu \mathrm{g} / \mathrm{L})$. The concentrations of dissolved aluminum and manganese followed the same trends downstream as the major cations and anions discussed above. Specifically, the concentrations of aluminum and manganese increased from EB-1080M to EB-770M, then decreased at EB-600M, and then increased drastically at EB-90M.

\section{Minor and Trace Inorganic Elements}

The only minor and trace elements present in significant concentrations in August 2006 in Ely Brook were Ba (17 to $19.9 \mu \mathrm{g} / \mathrm{L}), \mathrm{Cd}(<0.02$ to $1.99 \mu \mathrm{g} / \mathrm{L}), \mathrm{Co}(0.08$ to $63 \mu \mathrm{g} / \mathrm{L})$, $\mathrm{Cu}(1.3$ to $1,560 \mu \mathrm{g} / \mathrm{L}), \mathrm{Ni}(0.5$ to $19.5 \mu \mathrm{g} / \mathrm{L}), \mathrm{Sr}(47.6$ to $64 \mu \mathrm{g} / \mathrm{L})$, and $\mathrm{Zn}(5.6$ to $373 \mu \mathrm{g} / \mathrm{L})$ (fig. 7). In comparison, historical variations for Ely Brook showed a greater range (appendix 2). For example, historical dissolved copper concentrations, the most significant contaminant, approach $8,000 \mu \mathrm{g} / \mathrm{L}$ (Argue and others, 2008). Trace amounts of dissolved $\mathrm{Be}$ (up to $0.3 \mu \mathrm{g} / \mathrm{L}$ ), $\mathrm{Pb}$ (up to $0.95 \mu \mathrm{g} / \mathrm{L}$ ), and $\mathrm{U}$ (up to $0.42 \mu \mathrm{g} / \mathrm{L}$ ) were detected in some samples. The minimum value reported above was generally for background site EB-1080M, whereas the maximum value was for the farthest downstream site (EB-90M). The following elements follow this trend: $\mathrm{Be}, \mathrm{Cd}, \mathrm{Co}, \mathrm{Cu}, \mathrm{Ni}, \mathrm{Pb}, \mathrm{Sr}, \mathrm{U}$, and $\mathrm{Zn}$. Dissolved $\mathrm{Ag}, \mathrm{As}, \mathrm{Hg}, \mathrm{Sb}, \mathrm{Se}, \mathrm{Tl}$, and $\mathrm{V}$ concentrations were all below their detection limits.

\section{Dissolved Organic Carbon and Nutrients}

DOC concentrations throughout Ely Brook ranged from 0.8 to $1.9 \mathrm{mg} / \mathrm{L}$. Nutrients were generally low throughout the study area. Total dissolved nitrogen ranged from 0.04 to $0.07 \mathrm{mg} / \mathrm{L}$, and total dissolved phosphorus ranged from 0.002 to $0.004 \mathrm{mg} / \mathrm{L}$.

\section{Trace Element Loads}

Coupled streamflow measurements and surface-water samples obtained at sites EB-90M, EB-600M, EB-770M, and EB-1080M on August 23, 2006, were used to describe transport and attenuation of constituents in Ely Brook. Background conditions were characterized by samples obtained at EB-1080M. Instantaneous loads for most elements increased above background conditions by 1 to 2 orders of magnitude at EB-770M, below the confluence with Ely Brook tributary 4 (fig. 13). Total iron loads, however, were similar. As waters 


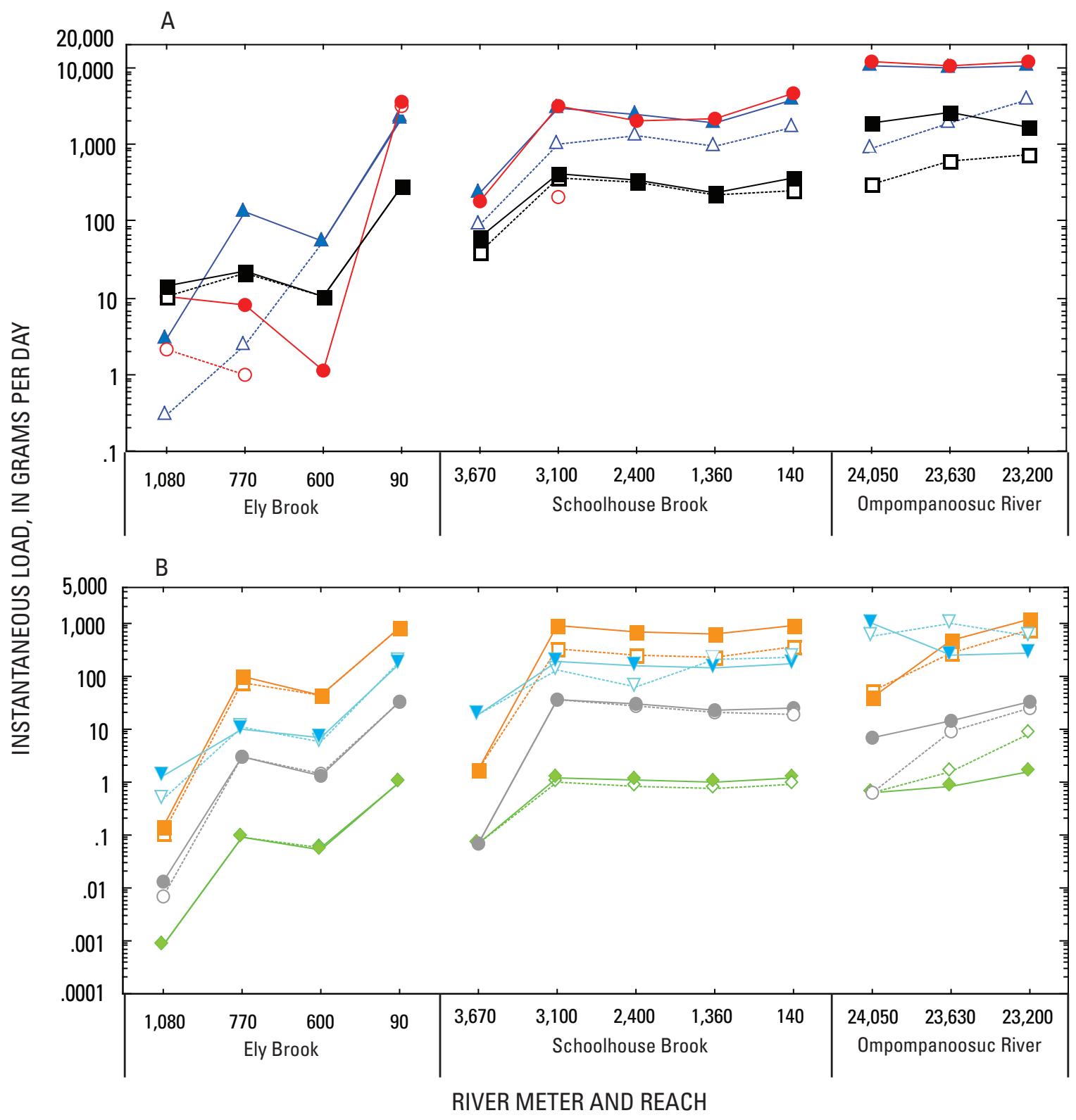

\section{Explanation}

Graph A

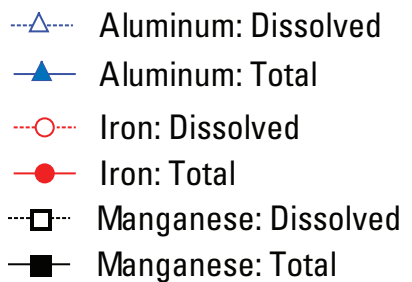

Graph B

$$
\begin{aligned}
& \cdots \text {-.... Cadmium: Dissolved } \quad \cdots \quad-\cdots \quad \text { Copper: Dissolved } \\
& \multimap \text { Cadmium: Total } \quad-\quad-\text { Copper: Total } \\
& \quad \cdots .-\cdots \text { Cobalt: Dissolved } \quad-\cdots \quad \text { Zinc: Dissolved } \\
& \rightarrow \text { Cobalt: Total } \quad \longrightarrow \text { Zinc: Total }
\end{aligned}
$$

Figure 13. Instantaneous $(A)$ aluminum, iron, and manganese, and $(B)$ cadmium, cobalt, copper, and zinc loads at the Ely Mine Superfund site, Vershire, VT. 
traveled downstream from EB-770M to EB-600M, there was a marked decrease in element loads. More than 50 percent of the total aluminum load and more than 50 percent of the total and dissolved manganese loads were removed. This is most likely the result of aluminum hydrolysis and manganese oxidation and hydrolysis. Instantaneous loads for most elements increased by 1 to 3 orders of magnitude as waters traveled from EB-600M to EB-90M because water from Ely Brook tributaries 1 and 2 drains into Ely Brook. The $\mathrm{pH}$ decreased from 6.9 to 3.2 from EB-600M to EB-90M and resulted in most element loads being dominated by the dissolved phase (fig. 13).

\section{Comparisons with Ambient Water-Quality Criteria and Relations among Reaches}

Ely Brook was partitioned into four reaches for analysis of water data based on the relationship to confluences with tributaries 1, 2, and 4. Stream reach 1, defined by locations sampled from river meter 0 to 350 , was partitioned to describe water-quality conditions near the mouth of Ely Brook. Stream reach 2, defined by locations sampled from river meter 350 to 540 , was partitioned to describe water-quality conditions downstream of the confluence with Ely Brook tributary 2. Stream reach 3 , defined by locations sampled from river meter 540 to 800 , was partitioned to describe water-quality conditions downstream of the confluence with Ely Brook tributary 4. Insufficient water samples were collected in stream reach 3 to allow for statistical analysis of variance for most trace elements. Background conditions were characterized by locations sampled above river meter 800 .

Concentrations greater than AWQC were observed in stream reach 1 for $\mathrm{Al}, \mathrm{Ba}, \mathrm{Cd}, \mathrm{Co}, \mathrm{Cu}, \mathrm{Fe}, \mathrm{Mn}, \mathrm{Hg}, \mathrm{Ag}$, and $\mathrm{Zn}$; in stream reach 2 for $\mathrm{Al}, \mathrm{Ba}, \mathrm{Cd}, \mathrm{Cr}, \mathrm{Co}, \mathrm{Cu}, \mathrm{Fe}, \mathrm{Mn}, \mathrm{Ag}$, $\mathrm{U}$, and $\mathrm{Zn}$; and in stream reach 3 for $\mathrm{Al}, \mathrm{Ba}, \mathrm{Co}, \mathrm{Cu}, \mathrm{Mn}$, and $\mathrm{Zn}$ (appendix 5). Concentrations of most elements in reaches 1 and 2 were generally greater than background conditions by 1 to 3 orders of magnitude (fig. 14) with the exception of Ba and $\mathrm{Ag}$, which were similar among reaches and background conditions (rho > 0.05 ). Concentrations of $\mathrm{Co}, \mathrm{Cu}$, and $\mathrm{Ni}$ in reach 3 were generally greater than and significantly different from $($ rho $<0.05)$ background conditions.

Concentrations of most elements increased with distance downstream in Ely Brook (fig. 14). Concentration of Al, Ba, $\mathrm{Cd}, \mathrm{Cr}, \mathrm{Co}, \mathrm{Cu}, \mathrm{Mn}$, and $\mathrm{Zn}$ were similar between stream reaches 1 and 2 (rho $>0.05$ ). However, concentrations of $\mathrm{Fe}$ and $\mathrm{U}$ in reach 1 and $\mathrm{Al}$ in reach 3 generally were less than and statistically different from reach $2($ rho $<0.05)$. Median concentrations of most constituents decreased between reaches 2 and 1 , most likely the result of iron oxidation, iron and aluminum hydrolysis, and sorption of associated metals. Based on the dramatic change in slope (table 2) and the observed $\mathrm{pH}$ of surface and pore waters (tables 4 and 5), this metal cycling may be occurring as groundwaters with higher $\mathrm{pH}$ discharge to the stream or as surface waters flow through the hyporheic zone and interact with shallow groundwater (Harvey and Fuller, 1998; Fuller and Harvey, 2000).

\section{Pore-Water Geochemistry}

Pore-water samples from Ely Brook were co-located with surface-water sites. The sites include EB-1080M, EB-770M, EB-600M, and EB-90M; SB-3670M is also discussed in the background conditions section. Chemical constituents for pore-water samples are summarized in table 5 , and complete analyses are reported in appendix 7.

\section{Field Parameters and Major Inorganic Constituents}

The $\mathrm{pH}$ and specific conductance were measured only on the in situ and equilibrated samples. The $\mathrm{pH}$ values for the in situ and equilibrated samples were comparable, and $\mathrm{pH}$ in the pore waters followed the same fluctuating trend as $\mathrm{pH}$ in the surface waters from the same sites (fig. 5). The $\mathrm{pH}$ decreased from EB-1080M to EB-770M, then increased at EB-600M, and then decreased drastically at EB-90M. The specific conductance, which was significantly higher in the equilibrated versus in situ splits, followed a reverse trend to the $\mathrm{pH}$ (fig. 5). A wide range in both $\mathrm{pH}$ and specific conductance occurred along Ely Brook; $\mathrm{pH}$ ranged from 2.9 to 7.5 , and specific conductance ranged from 85 to $1,063 \mu \mathrm{S} / \mathrm{cm}$.

Calcium and silica were the dominant dissolved cations, and $\mathrm{K}, \mathrm{Mg}$, and $\mathrm{Na}$ occur in lesser but subequal proportions; these relative proportions in the pore waters were similar to those in the surface waters. The concentrations of these elements in the pore waters fluctuated downstream; in general for each pore-water type, the lowest concentrations were found in the background site (EB-1080M), and the highest concentrations were found in the farthest downstream site (EB-90M). Also, the concentrations of the dissolved major cations were usually highest in the equilibrated samples $(\mathrm{Ca}$ : 21.6-69.5 mg/L; Mg: 3.16-9.29 mg/L; Na: $2.4-4.23 \mathrm{mg} / \mathrm{L}$; $\left.\mathrm{K}: 4.04-7.32 \mathrm{mg} / \mathrm{L} ; \mathrm{SiO}_{2}: 12.7-39.5 \mathrm{mg} / \mathrm{L}\right)$, and lowest in the in situ samples (Ca: 12.6-20.4 mg/L; Mg: 1.18-5.43 mg/L; Na: $1.13-2.34 \mathrm{mg} / \mathrm{L} ; \mathrm{K}: 1.68-4.87 \mathrm{mg} / \mathrm{L} ; \mathrm{SiO}_{2}$ : 9-32.8 mg/L). In general, the concentrations of major cations in the in situ waters were comparable to their concentrations in the surface waters. The hardness values of the pore waters followed the trends displayed by the major cations with the highest hardness found in equilibrated pore waters and the lowest values for in situ pore waters; in situ values were comparable to surface-water values. Alkalinity was the dominant anionic species in the background pore waters (EB-1080M) as with surface water, whereas sulfate dominated in the mine-impacted samples (EB-770M, EB-600M, and EB-90M) (fig. 6). Like the dissolved major cations, these anions were found in higher concentrations in the equilibrated samples than in the in situ samples. Alkalinity was not measured on the centrifuged splits because of insufficient sample volumes. The alkalinity and sulfate values of the in situ pore waters were generally equivalent to the alkalinity of the surface water (fig. 6). 

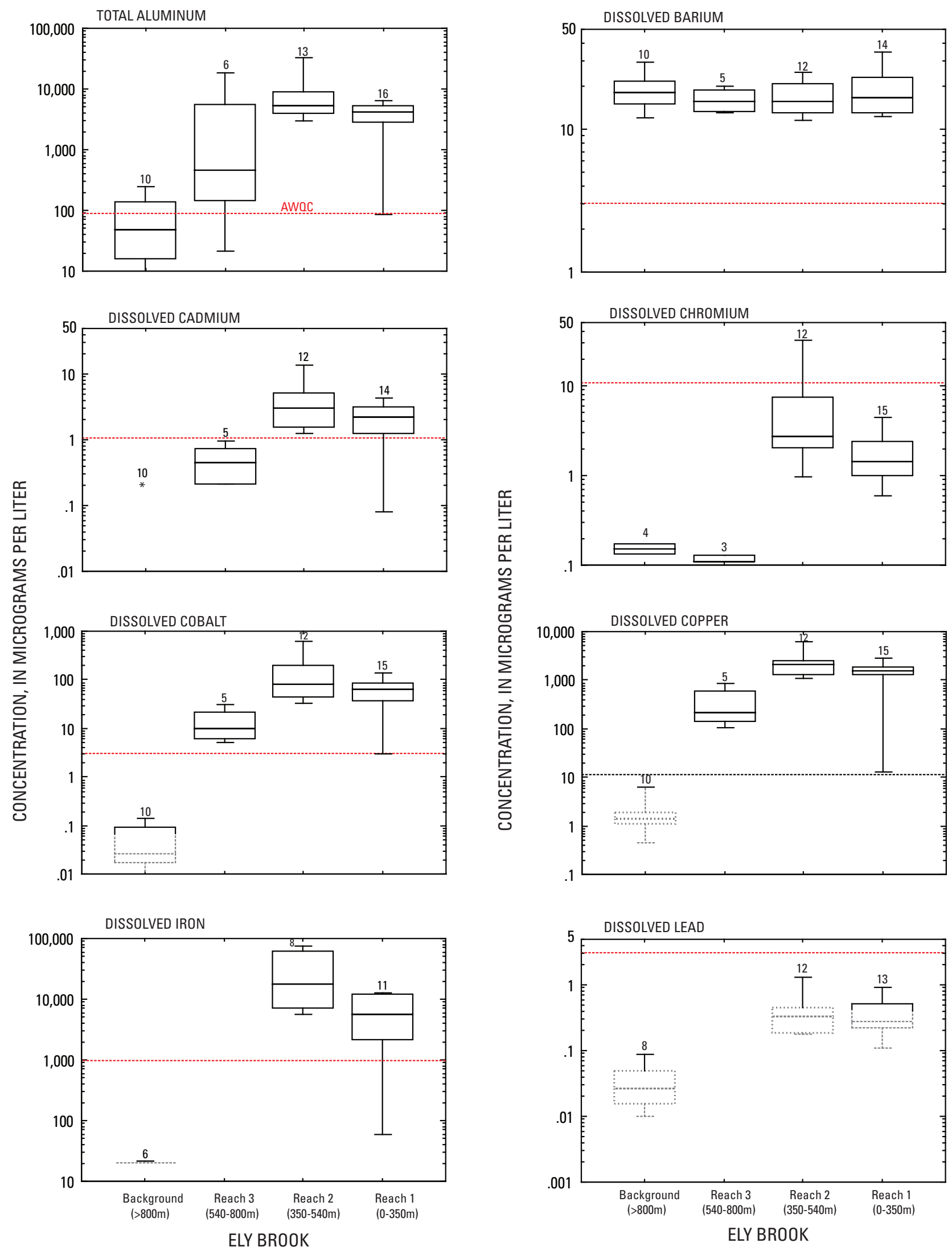

Figure 14. Select constituent concentrations in surface waters among four reaches in Ely Brook at the Ely Mine Superfund site, Vershire, VT. Data are from this study and Argue and others (2008). 


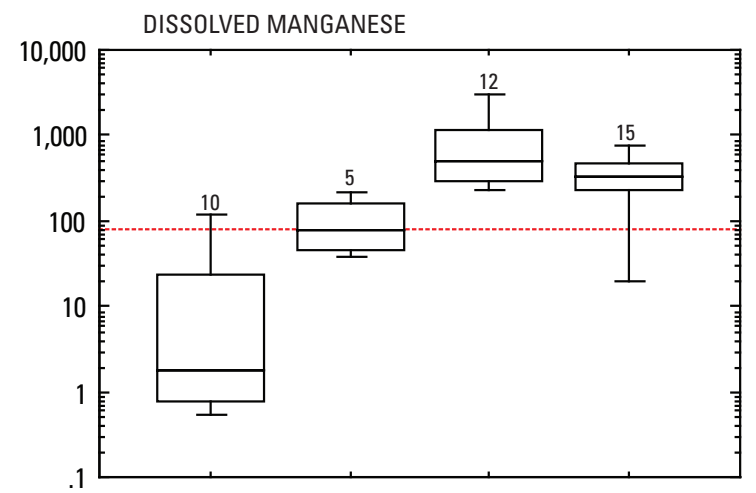

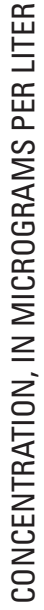

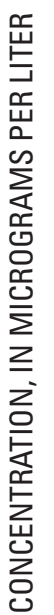
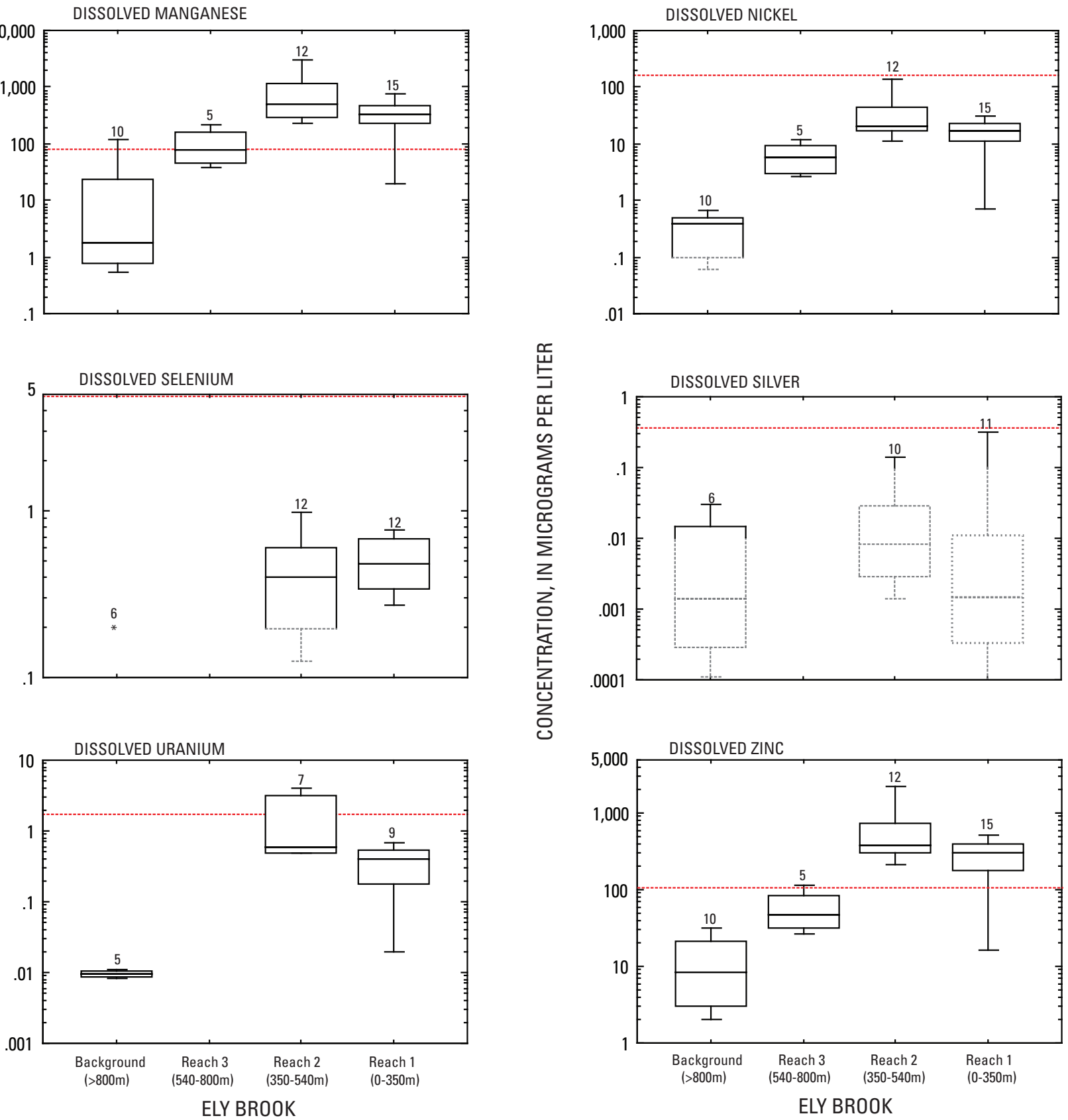

EXPLANATION

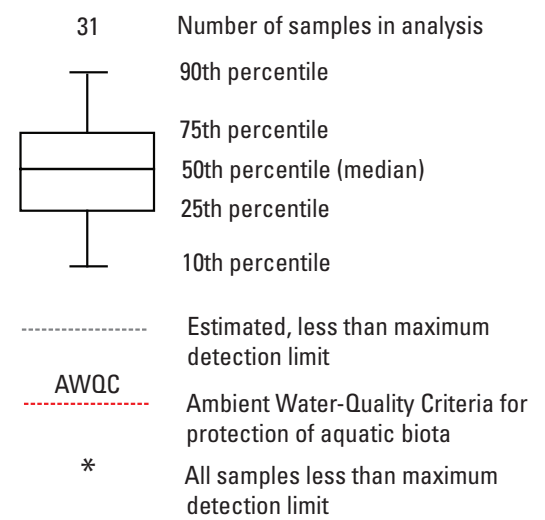

Figure 14. Select constituent concentrations in surface waters among four reaches in Ely Brook at the Ely Mine Superfund site, Vershire, VT. Data are from this study and Argue and others (2008)._-Continued 


\section{Iron, Aluminum, and Manganese}

The concentrations of dissolved $\mathrm{Fe}, \mathrm{Al}$, and $\mathrm{Mn}$ in pore waters fluctuated downstream according to the same variations seen in the major dissolved cations and anions discussed above. For the in situ pore-water types, the lowest concentrations were found in the background sample (EB-1080M) and the highest were found in the farthest downstream site (EB90M) (fig. 7). Iron was usually and Al was always the highest in the centrifuged splits with concentrations that ranged from 32 to $163,100 \mathrm{mg} / \mathrm{L}$ for Fe and 50.4 to $7,520 \mathrm{mg} / \mathrm{L}$ for $\mathrm{Al}$. In contrast to $\mathrm{Fe}$ and $\mathrm{Al}, \mathrm{Mn}$ was the highest in the equilibrated splits with concentrations that ranged from 418 to $5,460 \mathrm{mg} / \mathrm{L}$.

\section{Minor and Trace Inorganic Elements}

The minor and trace elements present in pore waters from Ely Brook were $\mathrm{Ba}(12.9$ to $74.7 \mu \mathrm{g} / \mathrm{L}), \mathrm{Cd}(<0.02$ to $2.87 \mu \mathrm{g} / \mathrm{L}), \mathrm{Co}(<0.02$ to $272 \mu \mathrm{g} / \mathrm{L}), \mathrm{Cu}(2.4$ to $2,140 \mu \mathrm{g} / \mathrm{L})$, $\mathrm{Ni}(0.6$ to $39 \mu \mathrm{g} / \mathrm{L}), \mathrm{Pb}(<0.05$ to $1.9 \mu \mathrm{g} / \mathrm{L}), \mathrm{Se}(<1$ to $2.9 \mu \mathrm{g} / \mathrm{L}), \operatorname{Sr}(46.1$ to $225 \mu \mathrm{g} / \mathrm{L})$, and $\mathrm{Zn}(1.5$ to $616 \mu \mathrm{g} / \mathrm{L}$ (fig. 7). The highest concentrations of $\mathrm{Cd}, \mathrm{Co}, \mathrm{Cu}, \mathrm{Ni}, \mathrm{Pb}$, $\mathrm{Se}$, and $\mathrm{Zn}$ were generally found in the pore waters from the farthest downstream site (EB-90M), and their lowest concentrations were generally in the pore waters from the background site (EB-1080M). The equilibrated and centrifuge samples generally contained higher concentrations of these elements compared to the in situ samples. Beryllium (up to $0.3 \mu \mathrm{g} / \mathrm{L}$ ), $\mathrm{Cr}$ (up $2.1 \mu \mathrm{g} / \mathrm{L}$ ), and $\mathrm{Sb}$ (up to $0.77 \mu \mathrm{g} / \mathrm{L}$ ) were only detected in the EB-90M pore waters. Uranium was detected in EB1080M (up to $0.49 \mu \mathrm{g} / \mathrm{L}$ ) and EB-90M (up to $1.01 \mu \mathrm{g} / \mathrm{L}$ ). Similar to surface waters, dissolved $\mathrm{Ag}, \mathrm{As}, \mathrm{Hg}, \mathrm{Tl}$, and $\mathrm{V}$ concentrations in all pore waters were near or below their detection limits.

\section{Dissolved Organic Carbon and Nutrients}

DOC and nutrient concentrations were determined only on the in situ pore-water samples. DOC concentrations throughout Ely Brook ranged from 1.0 to $1.6 \mathrm{mg} / \mathrm{L}$. Nutrients were generally low throughout the brook with total dissolved nitrogen ranging from 0.04 to $0.17 \mathrm{mg} / \mathrm{L}$ and total dissolved phosphorus ranging from 0.003 to $0.004 \mathrm{mg} / \mathrm{L}$.

\section{Comparisons with Ambient Water-Quality Criteria}

In the previous section, which discussed surface water in Ely Brook, sample sites were partitioned on the basis of stream reach and compared to ambient water-quality criteria. Hardness-dependent criteria were calculated on the basis of the hardness of the sample. This section will refer to the same stream reaches although pore waters are from this study, whereas surface waters included all historical samples. Pore waters were not sampled prior to this investigation. As in the previous section, stream reach 1 refers to water-quality conditions near the mouth of Ely Brook and downstream of Ely Brook tributary 1 (EB-90M); stream reach 3 refers to samples downstream of the confluence with Ely Brook tributary 4 and include sites EB-770M and EB-600M, and stream reach 4 refers to background samples (EB-1080M). Pore waters were not collected in stream reach 2, which was downstream of Ely Brook tributary 2 and upstream of Ely Brook tributary 1.

In stream reach 1 , the concentrations of the following elements exceeded their AWQCs in all samples: Al, Ba, Cd, Co, $\mathrm{Cu}, \mathrm{Fe}, \mathrm{Mn}$, and $\mathrm{Zn}$. Farther upstream in stream reach 3, the concentrations of $\mathrm{Ba}, \mathrm{Cd}$, and $\mathrm{Cu}$ in all pore waters exceeded their AWQC. Other exceedances in this stream reach include: $\mathrm{Al}$ in the centrifuged sample from EB-600M and Co and Mn from the equilibrated and centrifuged samples of EB-770M and the equilibrated sample of EB-600M. The concentrations for most elements in pore waters in stream reach 4 , the background site (SB-3670M), were less than AWQC with the exceptions being $\mathrm{Al}$ and $\mathrm{Cd}$ in the centrifuged sample, $\mathrm{Ba}$ in all pore waters, and $\mathrm{Mn}$ in equilibrated pore water.

\section{Sediment Geochemistry}

Sediment samples from Ely Brook include the four sites previously discussed (EB-1080M, EB-770M, EB-600M, and EB-90M) and an additional sample collected from site EB-90M from the uppermost layer of the overbank sediment. Chemical constituents for sediment samples are summarized in table 6, and complete analyses are reported in appendix 8. SEM-AVS data for sediment samples are summarized in table 7, and complete analyses are reported in appendix 4. This additional sample, EB-90M-OBS, was a grab sample of one discrete area instead of a composite of a larger section of the stream reach. The major element geochemistry of the background samples from Ely Brook (EB-1080M) reflected its siliciclastic constituents with 4.26 weight percent $\mathrm{Al}$, 2.76 weight percent $\mathrm{Fe}$, and between 0.98 and 1.05 weight percent $\mathrm{Ca}, \mathrm{K}, \mathrm{Mn}$, and $\mathrm{Na}$. In contrast, the mine-impacted sediment samples contained $\mathrm{Fe}>\mathrm{Al}>\mathrm{Ca}, \mathrm{K}, \mathrm{Mg}$, and $\mathrm{Na}$. In general, the concentration of $\mathrm{Fe}$ increased downstream, whereas the concentrations of $\mathrm{Al}, \mathrm{Ca}, \mathrm{K}, \mathrm{Mg}$, and Na decreased. The variation in $\mathrm{Fe}$ concentrations was the greatest and ranged from 5.5 weight percent at EB-770M to 16.7 weight percent at EB-90M and 36.3 weight percent at EB-90M-OBS. Also, sulfur increased from 0.04 weight percent at the background to 1.86 weight percent at EB-90M and 4.66 weight percent at EB-90M-OBS. Carbonate carbon was low, between 0.01 and 0.04 weight percent carbon. In contrast, total organic carbon was significantly higher than carbonate carbon and ranged from 0.23 to 0.53 weight percent for EB-1080M to EB-90M; the concentrations of organic carbon in EB-OBS was considerably higher at 2.42 weight percent. 
Maximum concentrations of trace elements in the Ely Brook stream sediments were $17 \mathrm{mg} / \mathrm{kg}$ for Ag (EB90M-OBS), $4 \mathrm{mg} / \mathrm{kg}$ for As (EB-90M), $360 \mathrm{mg} / \mathrm{kg}$ for Ba (EB-90M-OBS), $1 \mathrm{mg} / \mathrm{kg}$ for Cd (EB-600M and EB-90M), $65.5 \mathrm{mg} / \mathrm{kg}$ for Co (EB-600M), $89 \mathrm{mg} / \mathrm{kg}$ for Cr (EB-90MOBS), 5,950 mg/kg for Cu (EB-90M), 2,200 mg/kg for Mn (EB-90M), $44.5 \mathrm{mg} / \mathrm{kg}$ for Mo (EB-90M-OBS), $23.4 \mathrm{mg} / \mathrm{kg}$ for $\mathrm{Ni}(\mathrm{EB}-600 \mathrm{M}), 174 \mathrm{mg} / \mathrm{kg}$ for $\mathrm{Pb}(\mathrm{EB}-600 \mathrm{M}), 2.03 \mathrm{mg} / \mathrm{kg}$ for $\mathrm{Sb}$ (EB-90M), $71.1 \mathrm{mg} / \mathrm{kg}$ for Se (EB-90M-OBS), $133 \mathrm{mg} / \mathrm{kg}$ for Sr (EB-1080M), and $206 \mathrm{mg} / \mathrm{kg}$ for Zn (EB$90 \mathrm{M})$. The maximum concentrations of many of these elements were found in sediments from the farthest downstream reach of the stream (EB-90M and EB-90M-OBS). Mercury was below its detection limit of $0.02 \mathrm{mg} / \mathrm{kg}$ in all sediments except EB-90M-OBS with $0.13 \mathrm{mg} / \mathrm{kg}$.

Acid volatile sulfide for the stream-sediment samples from Ely Brook was below the detection limit of $23 \mathrm{mg} / \mathrm{kg}$ $(0.7 \mu \mathrm{moles} / \mathrm{g})$. The sum of the concentrations of simultaneously extracted metals $(\mathrm{Cd}+\mathrm{Cu}+\mathrm{Pb}+\mathrm{Ni}+\mathrm{Zn})$ was low in the background sample (EB-1080M) at $0.5 \mu \mathrm{mol} / \mathrm{g}$ and increased to $5.7 \mu \mathrm{mol} / \mathrm{g}$ (EB-770M) and $14.5 \mu \mathrm{mol} / \mathrm{g}$ (EB-600M). The concentration of SEM then decreased to $1.2 \mu \mathrm{mol} / \mathrm{g}$ at EB-90M. The samples from Ely Brook were the only ones in this study to contain detectable simultaneously extracted cadmium concentrations. Simultaneously extracted mercury was below its detection limit of $0.001 \mu \mathrm{mol} / \mathrm{g}$.

The concentrations of $\mathrm{As}, \mathrm{Cd}, \mathrm{Cr}, \mathrm{Cu}, \mathrm{Hg}, \mathrm{Ni}, \mathrm{Pb}$, and $\mathrm{Zn}$ in the sediments from Ely Brook are below the PEC limits, with the exception of $\mathrm{Cu}$ and $\mathrm{Pb}$. The concentrations of copper in all sediments that were impacted by the mine (EB-770M, EB-600M, and EB-90M) exceeded the PEC of $149 \mathrm{mg} / \mathrm{kg}$ with values that ranged from 1,160 to $5,950 \mathrm{mg} / \mathrm{kg}$. Also, the concentrations of lead in EB-600M sediment exceeded its PEC of $128 \mathrm{mg} / \mathrm{kg}$ with a concentration of 174 . The ( $\Sigma$ SEM$\mathrm{AVS}) / \mathrm{f}_{\mathrm{OC}}$ values for the background stream sediment from Ely Brook was $-61.5 \mu \mathrm{mol} / \mathrm{gOC}$, which was well within the noeffects range. In contrast, the $(\Sigma \mathrm{SEM}-\mathrm{AVS}) / \mathrm{f}_{\mathrm{OC}}$ for sediments EB-770M and EB-90M were 963.8 and $213.1 \mu \mathrm{mol} / \mathrm{gOC}$, respectively, which fall within the uncertain effects range (USEPA, 2005). Also, the ( $\Sigma S E M-A V S) / f_{\text {OC }}$ for sediment EB$600 \mathrm{M}$ was $6,050 \mu \mathrm{mol} / \mathrm{gOC}$, which falls within the predicted effects range, which has a lower limit of 3,000 $\mu \mathrm{mol} / \mathrm{gOC}$ (USEPA, 2005).

\section{Bioassay Results}

For the Ely Brook sediment samples, tests were conducted using Hyalella azteca for 28-day exposures and Chironomus dilutus for 12-day exposures (table 8). For both organisms, survival and growth endpoints were measured. For EB-1080M, the reference site, $H$. azteca had an acceptable survival at $93.8 \pm 1.8$ percent, and growth of $3.24 \pm 0.05 \mathrm{~mm}$. At EB-770M, survival dropped to $68.8 \pm 5.8$ percent, and growth was $2.45 \pm 0.06 \mathrm{~mm}$. At EB-600M, survival dropped to $6.3 \pm 2.6$ percent, and growth was $1.96 \pm 0.11 \mathrm{~mm}$. At EB-90M, the site with the most impaired surface- and porewater quality, survival was a surprising $91.3 \pm 4.0$ percent, and growth was $3.39 \pm 0.06 \mathrm{~mm}$.

The midge $(C$. dilutus) results were somewhat different. Site EB-1080M, the reference, had survival at $63.8 \pm$ 6.5 percent, and growth was $1.21 \pm 0.11 \mathrm{~mm}$. At EB-770M, survival was statistically identical at $61.3 \pm 4.8$ percent, and growth dropped to $0.61 \pm 0.11 \mathrm{~mm}$. At EB-600M, survival was statistically identical at $65.0 \pm 6.0$ percent, and growth was $0.28 \pm 0.01 \mathrm{~mm}$. At EB-90M, the site with the most impaired surface- and pore-water quality, survival increased to $72.5 \pm$ 4.5 percent, and growth was $1.73 \pm 0.37 \mathrm{~mm}$.

\section{Relations among Trace Elements in Surface Water, Pore Water, Sediment, and Aquatic Biota}

Surface water, pore water, and sediments were sampled in August 2006, and invertebrates were sampled in September 2006 at river meters 90, 600, 770, and 1,080 to relate water and sediment quality to aquatic biota. Background conditions were characterized by samples obtained at river meter 1,080 . HIs at the background location were less than 1 for the surface-water sample and greater than 1 for the pore-water and sediment samples (table 10). However, no HQ greater than 1 was observed in pore water or sediments (table 10). HIs below the confluence with Ely Brook tributary 4 were greater than 1 for all samples and ranged from 50 to 237 in surface waters, 9.2 to 279 in pore waters, and 8.7 to 41 in sediments (table 10).

An evaluation of the RTH and DTH invertebrate data sampled at the Ely Brook sites indicated severe impairment below the reference location EB-1080M. Between EB-1080M and EB-770M, RTH abundance decreased from 1,756 to 8 individuals, and RTH richness decreased from 43 to 7 taxa (fig. 9); DTH abundance decreased from 415 to 8 individuals, and DTH richness decreased from 34 to 7 taxa (figs. 9 and 10; table 9). A decrease in the values of these two metrics also was closely associated with the increase in HIs for metals concentrations in surface water (RTH abundance and richness decrease, fig. 15; table 9) and pore water (DTH abundance and richness decrease, fig. 16; table 9). This response with HI values was definite (rho $=-1.000$ ) for richness in both the RTH and DTH assemblages, even though an increase in HIs did not follow an up- to downgradient order in the surfacewater samples. These results indicated that the RTH and DTH invertebrate assemblages in Ely Brook were strongly affected by acid-mine drainage and that the level of contamination in the respective habitat (surface or pore water) is a relevant environmental factor in the response. 
A

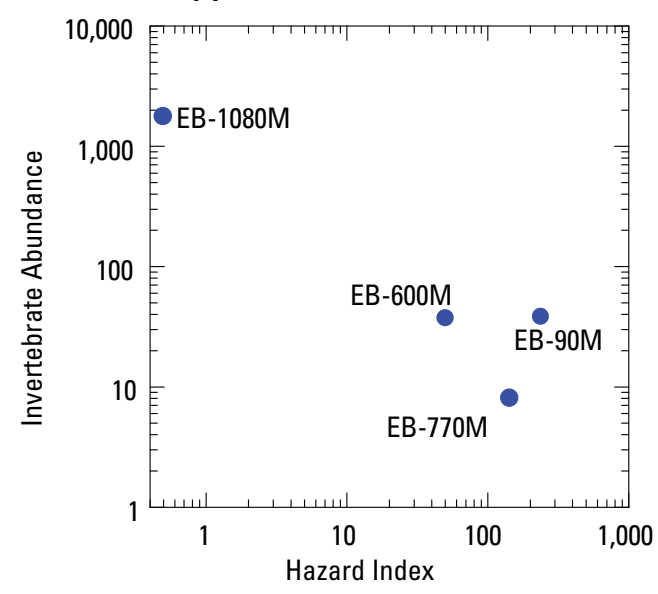

C

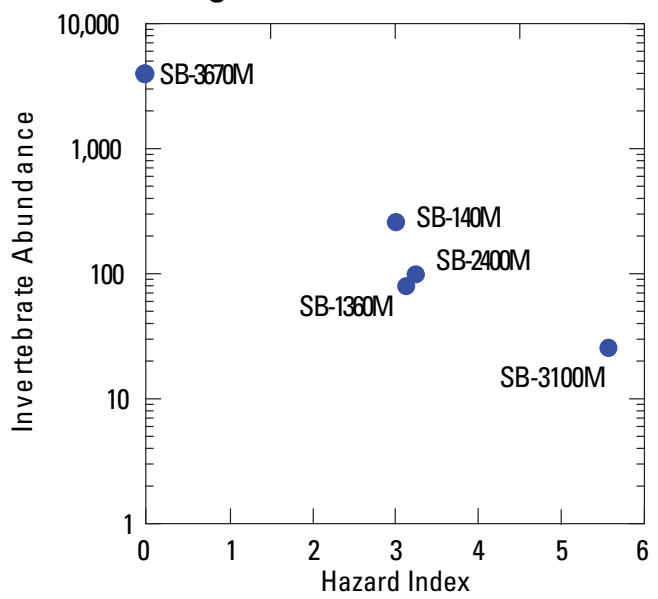

$E$

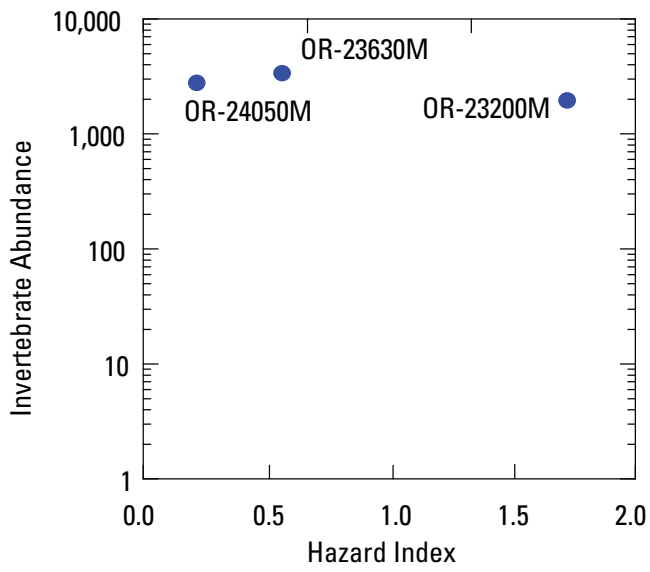

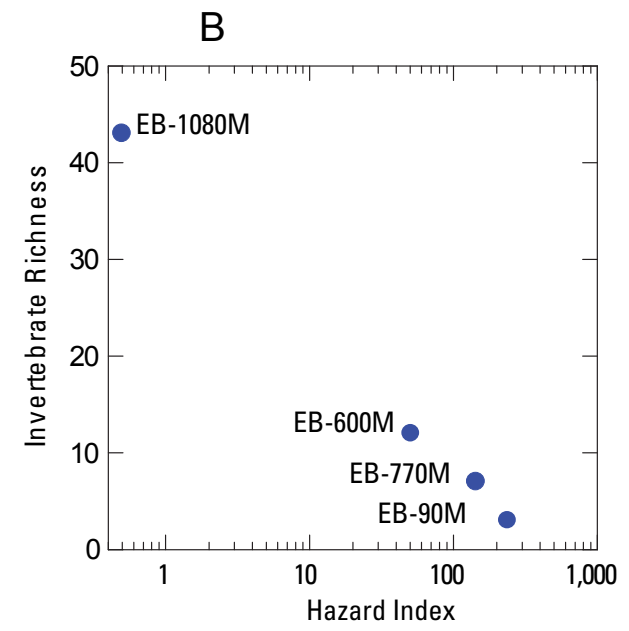

D
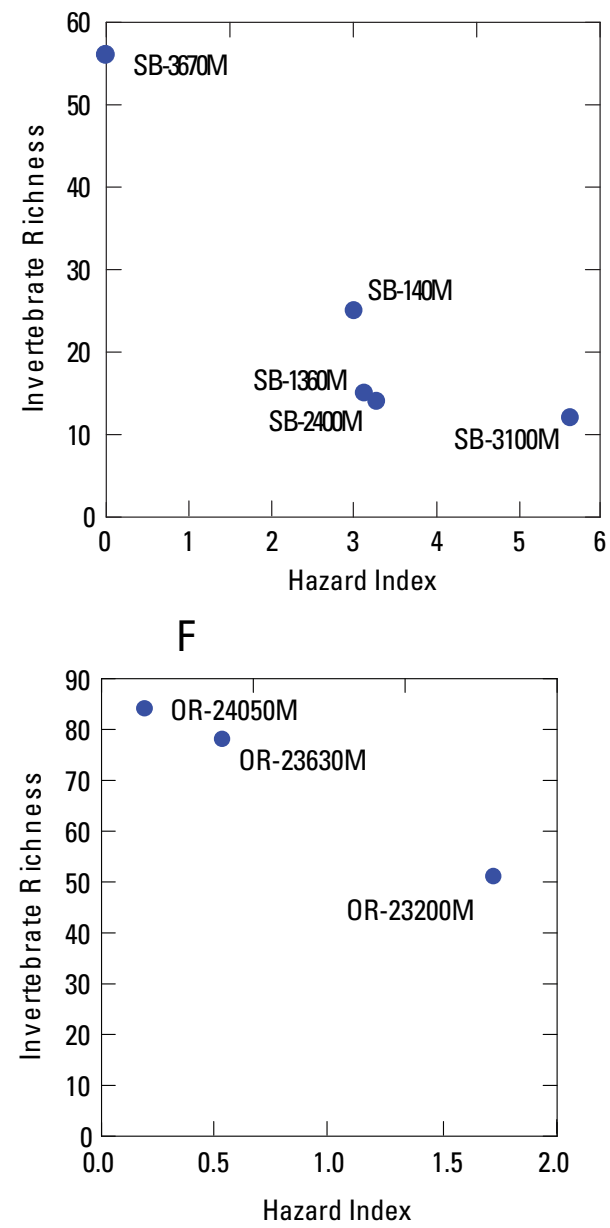

\section{Explanation}

OR-23200M - Sample location and identifier

Figure 15. Riffle-targeted habitat $(\mathrm{RTH})$ invertebrate $(A)$ abundance and $(B)$ richness values in Ely Brook, $(C)$ abundance and $(D)$ richness values in Schoolhouse Brook, and $(E)$ abundance and (F) richness values in the Ompompanoosuc River relative to the gradient in hazard index values derived from trace metal concentration in surface waters, Vershire, VT. The first location in each of the frames (lowest hazard index value) was coincidentally farthest upgradient from sources of contamination and was used to represent background conditions for the stream. 
A
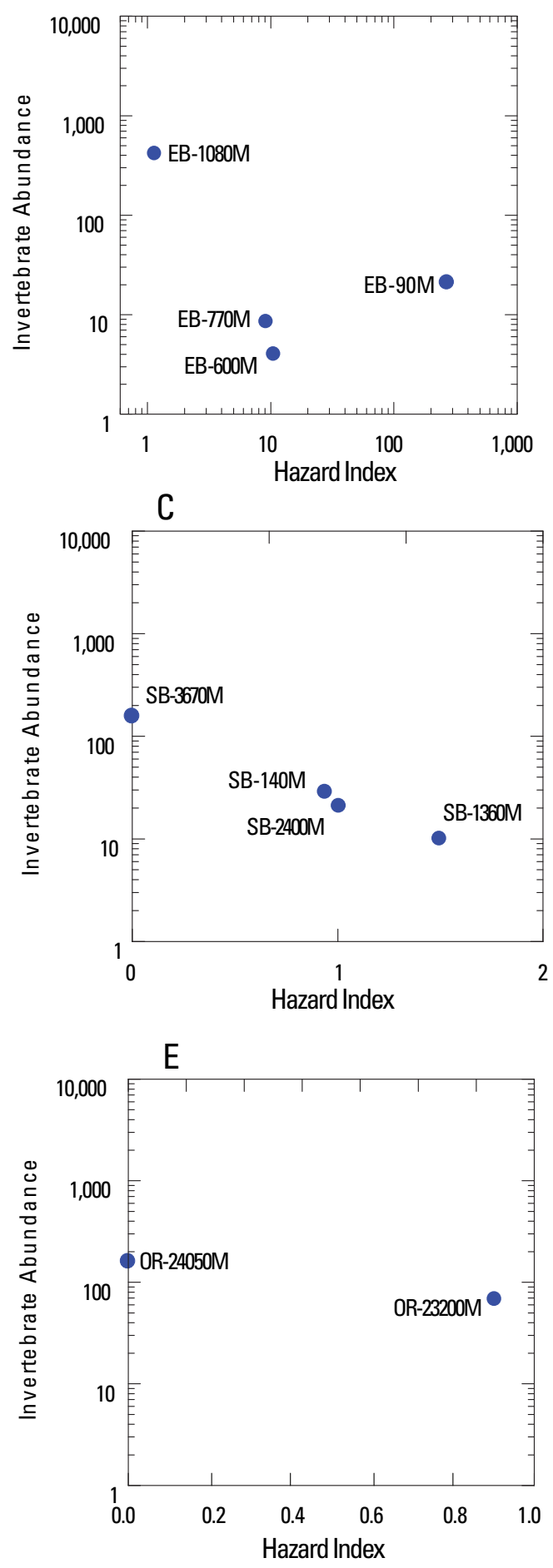

B
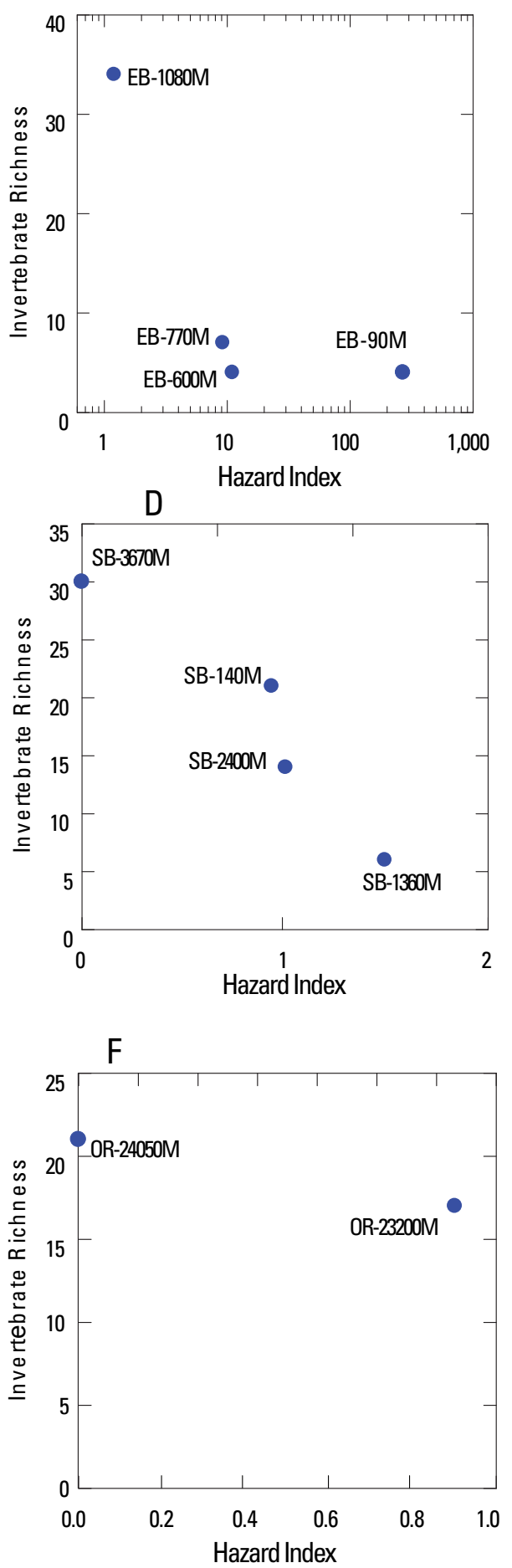

Explanation

OR-23200M $\bullet$ Sample location and identifier

Figure 16. Depositional-targeted habitat (DTH) invertebrate $(A)$ abundance and $(B)$ richness values in Ely Brook, $(C)$ abundance and $(D)$ richness values in Schoolhouse Brook, and (E) abundance and (F) richness values in the Ompompanoosuc River relative to the gradient in hazard index values derived from trace metal concentration in pore waters, Vershire, VT. The first location in each of the frames (lowest hazard index value) was coincidentally farthest upgradient from sources of contamination and was used to represent background conditions for the stream. 


\section{Schoolhouse Brook}

\section{Surface-Water Geochemistry}

Five sites were sampled in Schoolhouse Brook in August 2006, one of which was upstream of the confluence with Ely Brook and was also discussed in the background conditions section (SB-3670M). Chemical constituents for surface-water samples are summarized in table 4, and complete analyses are reported in appendix 6 . The four other Schoolhouse Brook sites include site SB-3125M, located approximately $125 \mathrm{~m}$ downstream from the confluence with Ely Brook, site SB-2400M, located approximately $850 \mathrm{~m}$ downstream from the confluence, site SB-1360M, located approximately $1,890 \mathrm{~m}$ downstream from the confluence, and site SB-140M, located approximately 3,110 m downstream from the confluence with Ely Brook and $140 \mathrm{~m}$ upstream of the confluence with the Ompompanoosuc River. Data from these sites will be used to examine downstream variations in chemistry.

\section{Field Parameters and Major Inorganic Constituents}

The $\mathrm{pH}$ of Schoolhouse Brook decreased slightly from 8.2 (SB-3670M) to 7.8 (SB-3125M) downstream of the confluence with Ely Brook due to mixing with acidic waters from Ely Brook (pH 3.2 at EB-90M) (fig. 5). In contrast to the $\mathrm{pH}$, the specific conductance and concentrations of most major dissolved cations did not vary significantly directly downstream from Ely Brook (fig. 5). However, most major dissolved cations increased slightly from SB-3125M to SB$2400 \mathrm{M}$ and then decreased farther downstream (SB-1360M and SB-140M). This is reflected in the hardness (in $\mathrm{mg} / \mathrm{L}$ $\mathrm{CaCO}_{3}$ ) increasing from 95.9 at SB-3125M to 97.8 at SB$2400 \mathrm{M}$, and then decreasing to 92.5 and 84.2 at SB-1360M and SB-140M, respectively (fig. 6). The decrease downstream may be due to dilution after mixing with a tributary downstream of SB-2400M. Alkalinity, the dominant anionic species, followed similar trends to hardness and ranged from 80 to $99 \mathrm{mg} / \mathrm{L} \mathrm{CaCO}_{3}$ (fig. 6). Chloride and sulfate concentrations reached 5 and $16 \mathrm{mg} / \mathrm{L}$, respectively; they did not vary significantly downstream in Schoolhouse Brook. Calcium was the dominant dissolved cation and ranged from 30.7 to $35.8 \mathrm{mg} / \mathrm{L}$. Other major cations include K (2.2 to $2.42 \mathrm{mg} / \mathrm{L})$, $\mathrm{Mg}$ (1.82 to $2.03 \mathrm{mg} / \mathrm{L}$ ), $\mathrm{Na}$ (3.77 to $4.62 \mathrm{mg} / \mathrm{L}$ ), and $\mathrm{SiO}_{2}$ (7.3 to $9.1 \mathrm{mg} / \mathrm{L}$ ). Previous reports found similar results (Seal and others, 2001; Holmes and others, 2002; Argue and others, 2008).

\section{Iron, Aluminum, and Manganese}

The concentrations of dissolved $\mathrm{Al}(93.5$ to $128 \mu \mathrm{g} / \mathrm{L}$ ) were considerably higher than the concentrations of dissolved Fe ( $<20$ to $49 \mu \mathrm{g} / \mathrm{L})$ and $\mathrm{Mn}(13.6$ to $43.8 \mu \mathrm{g} / \mathrm{L})$ in Schoolhouse Brook surface waters (excluding background site SB-3670M) (fig. 7). All three elements increased directly downstream from the confluence with Ely Brook due to mixing with the more concentrated waters of Ely Brook. Iron and manganese generally decreased downstream from SB-3125M to SB-140M.

\section{Minor and Trace Inorganic Elements}

The only minor and trace elements present in significant concentrations in August 2006 in Schoolhouse Brook downstream of the confluence with Ely Brook were Ba (14.8 to $19.8 \mu \mathrm{g} / \mathrm{L}), \mathrm{Co}(1.1$ to $4.31 \mu \mathrm{g} / \mathrm{L}), \mathrm{Cu}(20.4$ to $42.8 \mu \mathrm{g} / \mathrm{L})$, $\mathrm{Ni}$ (1 to $1.4 \mu \mathrm{g} / \mathrm{L}$ ), Sr (134 to $158 \mu \mathrm{g} / \mathrm{L}$ ), and $\mathrm{Zn}(6.6$ to $19.8 \mu \mathrm{g} / \mathrm{L})$. In comparison, historical variations for Schoolhouse Brook show a greater range (Argue and others, 2008). For example, dissolved copper concentrations, the most significant contaminant, ranged from approximately 6 to $100 \mu \mathrm{g} / \mathrm{L}$. Trace amounts of dissolved $\mathrm{Cd}$ (up to $0.12 \mu \mathrm{g} / \mathrm{L}$ ), $\mathrm{Pb}$ (up to $0.1 \mu \mathrm{g} / \mathrm{L}$ ), $\mathrm{Sb}(0.78 \mu \mathrm{g} / \mathrm{L}$ ), and $\mathrm{U}$ (up to $0.31 \mu \mathrm{g} / \mathrm{L}$ ) were detected in some or all samples. The concentrations of most of these elements were below their detection limits upstream of Ely Brook at SB-3670M and increase at SB-3125M due to mixing with the more concentrated water of Ely Brook (fig. 7). Dissolved Ag, As, Be, Cr, Hg, Se, Tl, and V concentrations were all below their detection limits.

\section{Dissolved Organic Carbon and Nutrients}

DOC concentrations throughout Schoolhouse Brook ranged from 1.2 to $2 \mathrm{mg} / \mathrm{L}$. Nutrients were generally low throughout the study area. Total dissolved nitrogen ranged from 0.09 to $0.12 \mathrm{mg} / \mathrm{L}$, and total dissolved phosphorus ranged from 0.003 to $0.006 \mathrm{mg} / \mathrm{L}$.

\section{Trace-Element Loads}

Coupled streamflow measurements and surface-water samples obtained at SB-140M, SB-1360M, SB-2400M, SB$3100 \mathrm{M}$, and SB-3670M on August 21 and 22, 2006, were used to describe the transport and attenuation of constituents in Schoolhouse Brook. Background conditions were characterized by samples obtained at SB-3670M. Instantaneous loads for most elements increased above background conditions at river meter 3,100, below the confluence with Ely Brook, and decreased with distance from SB-3125M to SB-1360M (fig. 13). An increase in instantaneous loads for most elements was observed from SB-1360M to SB-140M, most likely the result of samples being collected at different streamflow regimes. Streamflow at SB-140M was measured on August 21 at a probability of exceedance of approximately 40 percent, whereas streamflow at the other locations was measured on August 22 at a probability of exceedance of approximately 50 percent. Normalizing streamflow by drainage area at each location shows a marked increase in runoff per unit increase in drainage area at SB-140M relative to other locations. 
Comparisons with Ambient Water-Quality Criteria and Relations among Reaches

Schoolhouse Brook was divided into three reaches for analysis of water data based on the proximity to runoff associated with the Ely Mine site and the confluence with a tributary. Stream reach 1, defined by locations sampled from river meter 0 to 2,915 , was separated to describe water-quality conditions above the mouth of Schoolhouse Brook. Stream reach 2, defined by locations sampled from river meter 2,915 to 3,270 , was partitioned to describe water-quality conditions downstream of the confluence with Ely Brook and above a major tributary to Schoolhouse Brook. Stream reach 3, defined by locations sampled above river meter 3,270, was partitioned to describe background conditions.

Concentrations in surface waters greater than AWQC were observed in reaches 1 and 2 for $\mathrm{Al}, \mathrm{Ba}, \mathrm{Co}, \mathrm{Cu}$, and $\mathrm{Hg}$ (appendix 5). Concentrations of $\mathrm{Al}, \mathrm{Ba}$, and $\mathrm{Cu}$ in reach 1 and $\mathrm{Al}, \mathrm{Ba}, \mathrm{Co}$, and $\mathrm{Cu}$ in reach 2 were generally greater than AWQC (fig. 17) and significantly different from (rho < 0.05) background conditions. Concentrations of $\mathrm{Cd}, \mathrm{Co}, \mathrm{Fe}, \mathrm{Mn}$, and $\mathrm{Ni}$ in reach 1 were generally were less than AWQC (fig. 17) but significantly different from $($ rho $<0.05)$ those observed in reach 2 , most likely due to dilution with waters from tributaries, as indicated by the limited variations in the loads of these elements in Schoolhouse Brook (fig. 13).

\section{Pore-Water Geochemistry}

Pore-water samples from Schoolhouse Brook were collected with surface-water samples except for site SB-3125M. The sites include SB-3670M, SB-2400M, SB-1360M, and SB-140M; SB-3670M is also discussed in the background conditions section. Minor, but significant differences in the chemical composition among the three types of pore-water samples were noted. Chemical constituents for pore-water samples are summarized in table 5 and complete analyses are reported in appendix 7.

\section{Field Parameters and Major Inorganic Constituents}

The $\mathrm{pH}$ and specific conductance were measured only on the in situ and equilibrated samples. The pore waters for all sites on Schoolhouse Brook including background site SB-3670M were near neutral with $\mathrm{pH}$ ranging from 7.4 to 7.8 (fig. 5). In contrast to the specific conductance of the surface waters, which did not vary significantly downstream, the specific conductance of the in situ pore waters increased significantly from $251 \mu \mathrm{S} / \mathrm{cm}$ at SB-3670M to $347 \mu \mathrm{S} / \mathrm{cm}$ at SB-2400M downstream of the confluence with Ely Brook and then decreased to $218 \mu \mathrm{S} / \mathrm{cm}$ at SB-1360M and $260 \mu \mathrm{S} / \mathrm{cm}$ at SB-140M (fig. 5). The specific conductance of the equilibrated pore waters did not increase significantly downstream of the Ely Brook confluence. The specific conductance of all equilibrated pore waters was considerably higher (523 to $563 \mu \mathrm{S} / \mathrm{cm}$ ) when compared to that of the in situ pore waters ( 218 to $347 \mu \mathrm{S} / \mathrm{cm}$ ); the in situ pore-water values were slightly higher or comparable to those of the surface waters.
Calcium was the dominant dissolved cation, and $\mathrm{K}, \mathrm{Mg}$, $\mathrm{Na}$, and $\mathrm{SiO}_{2}$ occur in subequal proportions, similar to the surface-water samples. The concentrations of these constituents were generally higher downstream of the confluence with Ely Brook compared to the upstream site SB-3670M. The concentrations of dissolved major cations were usually highest in the equilibrated samples (Ca: 92.1 to $104 \mathrm{mg} / \mathrm{L} ; \mathrm{Mg}$ : 4.3 to $5.7 \mathrm{mg} / \mathrm{L}$; Na: 6.3 to $15.3 \mathrm{mg} / \mathrm{L} ; \mathrm{K}: 5.0$ to $7.4 \mathrm{mg} / \mathrm{L} ; \mathrm{SiO}_{2}$ : 11.8 to $16.5 \mathrm{mg} / \mathrm{L}$ ), and lowest in the in situ samples (Ca: 34.6 to $46.6 \mathrm{mg} / \mathrm{L} ; \mathrm{Mg}$ : 1.9 to $3.2 \mathrm{mg} / \mathrm{L}$; Na: 3.8 to $16.2 \mathrm{mg} / \mathrm{L}$; K: 2.5 to $4.1 \mathrm{mg} / \mathrm{L} ; \mathrm{SiO}_{2}: 7.6$ to $10.3 \mathrm{mg} / \mathrm{L}$ ). Alkalinity was the dominant anionic species and like the major cations was found in higher concentrations in the equilibrated samples (173 to $284 \mathrm{mg} / \mathrm{L} \mathrm{CaCO}_{3}$ ) than in the in situ samples (92 to $126 \mathrm{mg} / \mathrm{L}$ $\mathrm{CaCO}_{3}$ ). The alkalinity values of the in situ pore waters were higher than surface waters (fig. 6). The hardness values of the pore waters follow identical trends with the highest hardness found in equilibrated pore waters, intermediate values for in situ pore waters, and the lowest values in surface waters (fig. 6). Sulfate concentrations were higher than chloride concentrations, reaching 99 and $14 \mathrm{mg} / \mathrm{L}$, respectively.

\section{Iron, Aluminum, and Manganese}

Dissolved iron concentrations were below the detection limit of $20 \mu \mathrm{g} / \mathrm{L}$ for all in situ and equilibrated pore waters except in equilibrated pore water from SB-2400M $(30 \mu \mathrm{g} / \mathrm{L})$ (fig. 7). In contrast, the dissolved concentrations of iron in the centrifuged samples ranged from 28 to $213 \mu \mathrm{g} / \mathrm{L}$; these maximum concentrations were found in SB-2400M. The concentrations of dissolved aluminum ranged from 6.1 to $15 \mu \mathrm{g} / \mathrm{L}$ in in situ pore waters, from 14 to $197 \mu \mathrm{g} / \mathrm{L}$ in the centrifuged sampled, and from 8.5 to $38.2 \mu \mathrm{g} / \mathrm{L}$ in the equilibrated samples. The highest dissolved aluminum was always in the centrifuged sample. Dissolved Mn concentrations were generally significantly higher than $\mathrm{Al}$ and $\mathrm{Fe}$ concentrations and reached $113 \mu \mathrm{g} / \mathrm{L}$ in the in situ pore waters, $209 \mu \mathrm{g} / \mathrm{L}$ in centrifuged pore waters, and 3,870 $\mu \mathrm{g} / \mathrm{L}$ in equilibrated pore waters. Background site SB-3670M contained the highest manganese concentration, $3,870 \mu \mathrm{g} / \mathrm{L}$. However, the concentrations of manganese in the in situ and centrifuged pore waters from SB$3670 \mathrm{M}$ were only 0.4 and $6.8 \mu \mathrm{g} / \mathrm{L}$, respectively.

\section{Minor and Trace Inorganic Elements}

The minor and trace elements present in pore waters from Schoolhouse Brook were Ba (up to $75.7 \mu \mathrm{g} / \mathrm{L}$ ), Cd (up to $0.4 \mu \mathrm{g} / \mathrm{L}$ ), Co (up to $4.28 \mu \mathrm{g} / \mathrm{L}$ ), $\mathrm{Cu}$ (up to $24.9 \mu \mathrm{g} / \mathrm{L}$ ), Ni (up to $4.1 \mu \mathrm{g} / \mathrm{L}$ ), $\mathrm{Pb}$ (up to $0.2 \mu \mathrm{g} / \mathrm{L}$ ), $\mathrm{Sb}$ (up to $0.88 \mu \mathrm{g} / \mathrm{L}$ ), Se (up to $1.5 \mu \mathrm{g} / \mathrm{L}$ ), Sr (up to $457 \mu \mathrm{g} / \mathrm{L}$ ), U (up to $1.07 \mu \mathrm{g} / \mathrm{L}$ ), and $\mathrm{Zn}$ (up to $149 \mu \mathrm{g} / \mathrm{L}$ ). The highest concentrations of these elements were generally found in the equilibrated pore waters, and the lowest concentrations were generally found in the in situ pore waters. The concentrations of $\mathrm{Cd}, \mathrm{Co}, \mathrm{Cu}, \mathrm{Se}$, and $\mathrm{Zn}$ were higher in pore waters downstream of the confluence with Ely Brook (SB-2400M) compared to upstream (SB-3670M) (fig. 7). Similar to surface waters, dissolved Ag, As, Be, Cr, $\mathrm{Hg}, \mathrm{Tl}$, and $\mathrm{V}$ concentrations in all pore waters were near or below their detection limits. 

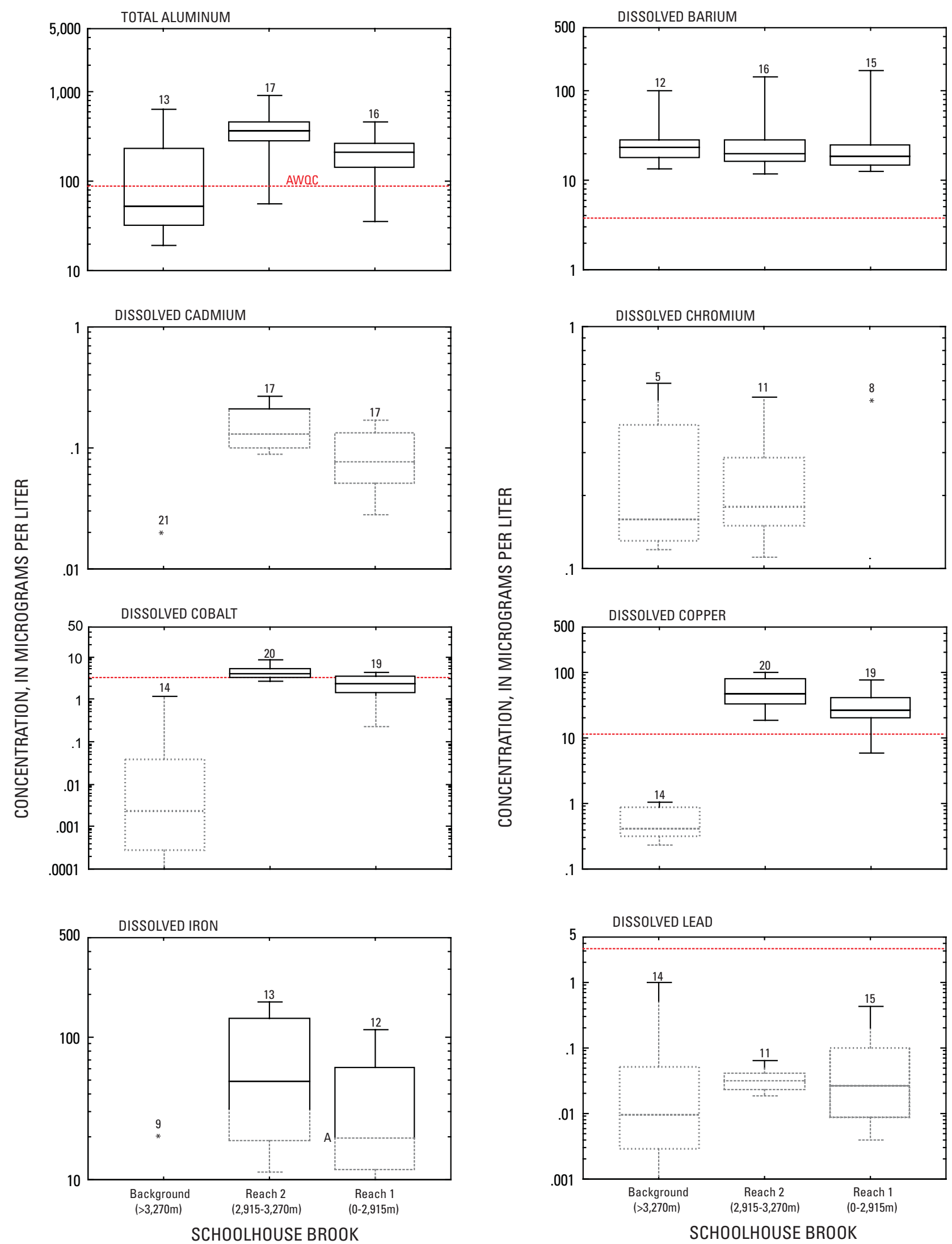

Figure 17. Select constituent concentrations in surface waters among three reaches in Schoolhouse Brook at the Ely Mine Superfund site, Vershire, VT. Data are from this study and Argue and others (2008). 

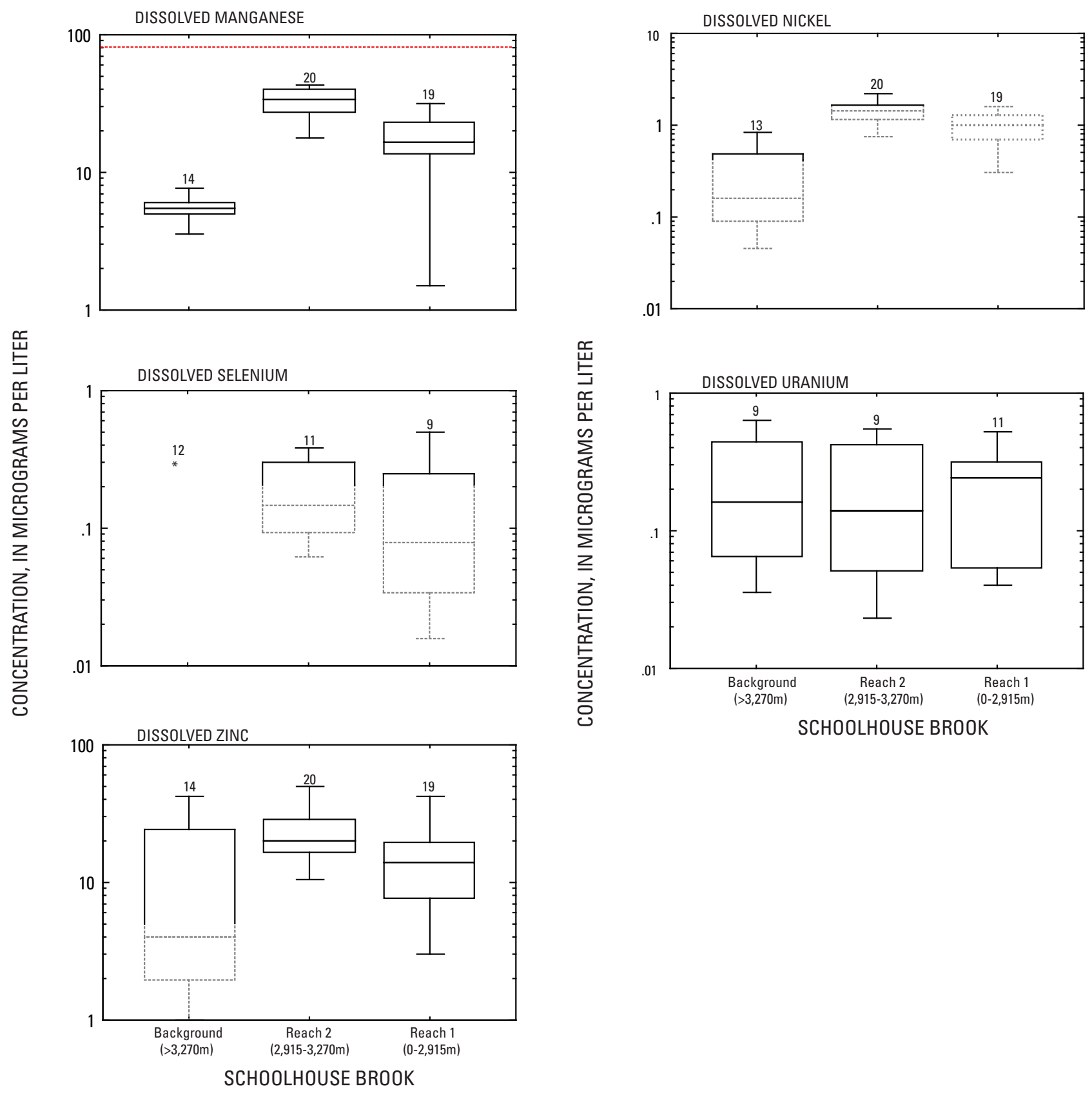

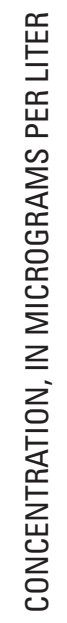

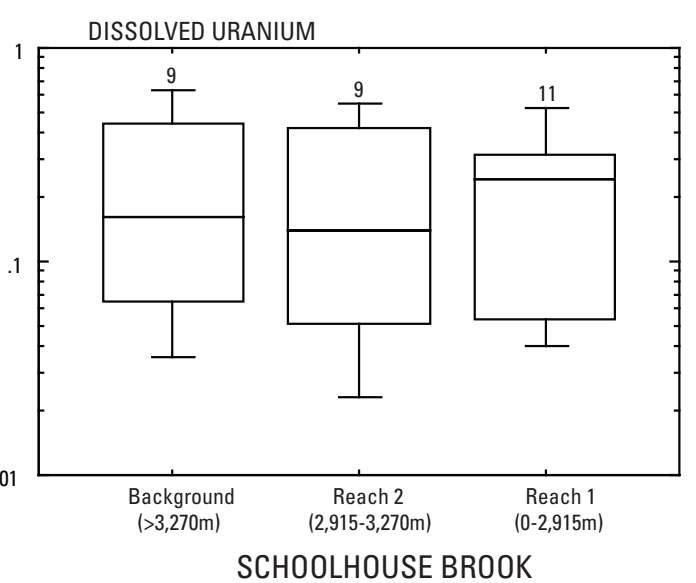

\section{EXPLANATION}

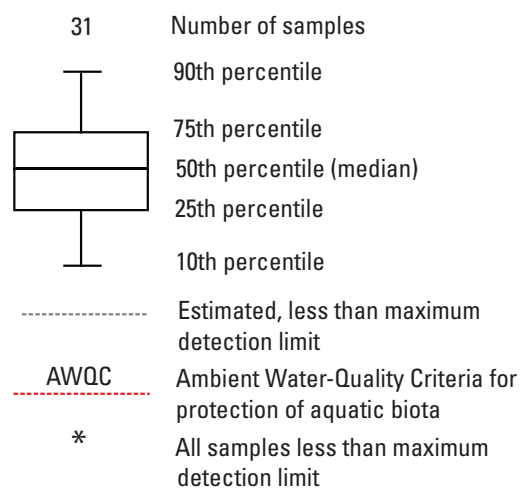

Figure 17. Select constituent concentrations in surface waters among three reaches in Schoolhouse Brook at the Ely Mine Superfund site, Vershire, VT. Data are from this study and Argue and others (2008).-Continued 


\section{Dissolved Organic Carbon and Nutrients}

DOC and nutrient concentrations were determined only on samples of the in situ pore water. DOC concentrations throughout Schoolhouse Brook ranged from 0.9 to $1.6 \mathrm{mg} / \mathrm{L}$. Nutrients were generally low throughout the brook with total dissolved nitrogen ranging from 0.07 to $0.24 \mathrm{mg} / \mathrm{L}$ and total dissolved phosphorus ranging from 0.004 to $0.006 \mathrm{mg} / \mathrm{L}$.

\section{Comparisons with Ambient Water-Quality Criteria}

In the previous section on surface water in Schoolhouse Brook, sample sites were partitioned on the basis of stream reach and compared to ambient water-quality criteria. Hardness-dependent criteria were calculated based on the hardness of the sample. This section will refer to the same stream reaches, although pore waters are from this study, whereas surface waters included all historical samples. Pore waters were not sampled prior to this investigation. As in the previous section, stream reach 1 refers to water-quality conditions above the mouth of Schoolhouse Brook and downstream of a major tributary (SB-2400M, SB-1360M, and SB-140M); stream reach 3 refers to background conditions (SB-3670M). Pore waters were not collected in stream reach 2 , which is downstream of the confluence with Ely Brook and upstream of a major tributary to Schoolhouse Brook.

The concentrations for most elements in pore waters in stream reach 3, the background site (SB-3670M), were less than AWQC with the exceptions being $\mathrm{Al}$ in the centrifuged split, $\mathrm{Ba}$ in all pore waters, and $\mathrm{Mn}$ in equilibrated pore water. The concentrations of $\mathrm{Ba}$ in all pore waters and $\mathrm{Mn}$ in most pore waters in stream reach 1 exceeded their AWQC of 3.8 and $80.3 \mu \mathrm{g} / \mathrm{L}$, respectively. In stream reach 1 , the concentrations of copper exceeded its hardness-dependent criterion in all of the equilibrated samples, most of the centrifuged samples (two of three samples), and one in situ sample. Cobalt, $\mathrm{Al}$, and $\mathrm{Zn}$ exceeded their criteria in one to two samples for each element.

\section{Sediment Geochemistry}

The major-element geochemistry of the four sediment samples from Schoolhouse Brook (SB-3670M, SB-2400M, SB-1360M, and SB-140M) reflects their siliciclastic constituents. Chemical constituents for sediment samples are summarized in table 6 , and complete analyses are reported in appendix 8. SEM-AVS data for sediment samples are summarized in table 7, and complete analyses are reported in appendix 4 . Aluminum ranged from 3.1 to 3.7 weight percent, Fe from 1.39 to 2.78 weight percent, and $\mathrm{Ca}$ from 1.3 to 1.62 weight percent. Magnesium, $\mathrm{K}$, and $\mathrm{Na}$ occurred in subequal proportions with concentrations that ranged from 0.6 to 0.9 weight percent. In general, the order of abundance of elements in the sediments was the following: $\mathrm{Al}>\mathrm{Fe}>\mathrm{Ca}>\mathrm{K}>\mathrm{Na}>\mathrm{Mg}$. Of these elements, only $\mathrm{Al}, \mathrm{Fe}$, and $\mathrm{Na}$ increased significantly downstream from the confluence with Ely Brook (SB-2400M) compared to the background sample site (SB-3670M). Also, sulfur increased from 0.03 to 0.08 weight percent downstream of the confluence with Ely Brook. Carbonate carbon was low, between 0.1 and 0.2 weight percent carbon; total organic carbon was slightly higher and ranged from 0.2 to 0.3 weight percent.

Maximum concentrations of trace elements in the Schoolhouse Brook stream sediments are $3 \mathrm{mg} / \mathrm{kg}$ for As (SB$3670 \mathrm{M}), 207 \mathrm{mg} / \mathrm{kg}$ for $\mathrm{Ba}$ (SB-3670M), $13.5 \mathrm{mg} / \mathrm{kg}$ for Co (SB-140M), $32 \mathrm{mg} / \mathrm{kg}$ for Cr (SB-140M), $243 \mathrm{mg} / \mathrm{kg}$ for $\mathrm{Cu}$ (SB-140M), $869 \mathrm{mg} / \mathrm{kg}$ for Mn (SB-140M), $2.59 \mathrm{mg} / \mathrm{kg}$ for Mo (SB-140M), $13.6 \mathrm{mg} / \mathrm{kg}$ for Ni (SB-140M), $31.4 \mathrm{mg} / \mathrm{kg}$ for $\mathrm{Pb}(\mathrm{SB}-140 \mathrm{M}), 2.14 \mathrm{mg} / \mathrm{kg}$ for $\mathrm{Sb}$ (SB-140M), $1.8 \mathrm{mg} / \mathrm{kg}$ for Se (SB-2400M), $206 \mathrm{mg} / \mathrm{kg}$ for $\mathrm{Sr}(\mathrm{SB}-1360 \mathrm{M})$, and $85 \mathrm{mg} / \mathrm{kg}$ for $\mathrm{Zn}$ (SB-140M). The concentrations of Co, Cu, $\mathrm{Mo}, \mathrm{Sb}, \mathrm{Se}$, and $\mathrm{Zn}$ increased significantly downstream from the confluence with Ely Brook (SB-2400M) in comparison to the background Schoolhouse Brook site (SB-3670M). Ag, Cd, and $\mathrm{Hg}$ were near or below their detection limits.

Acid volatile sulfide for the stream-sediment samples from Schoolhouse Brook were below the detection limit of $23 \mathrm{mg} / \mathrm{kg}(0.7 \mu \mathrm{mol} / \mathrm{g})$. The sum of the concentrations of simultaneously extracted metals $(\mathrm{Cd}+\mathrm{Cu}+\mathrm{Pb}+\mathrm{Ni}+\mathrm{Zn})$ was low in the background sample (SB-3670M) at $0.2 \mu \mathrm{mol} / \mathrm{g}$ and increased downstream of the confluence with Ely Brook to $1.3 \mu \mathrm{mol} / \mathrm{g}$ (SB-2400M), and then increased slightly to 1.4 and $1.6 \mu \mathrm{mol} / \mathrm{g}$ at SB-1360M and SB-140M, respectively. Simultaneously extracted $\mathrm{Cd}$ and $\mathrm{Hg}$ were below their detection limits.

The concentrations of $\mathrm{As}, \mathrm{Cd}, \mathrm{Cr}, \mathrm{Cu}, \mathrm{Hg}, \mathrm{Ni}, \mathrm{Pb}$, and $\mathrm{Zn}$ in the sediments from Schoolhouse Brook are below their PEC limits with the exception of $\mathrm{Cu}$ (table 10). The concentrations of copper in all sediments below the confluence with Ely Brook exceeded the PEC of $149 \mathrm{mg} / \mathrm{kg}$ with values that ranged from 167 to $243 \mathrm{mg} / \mathrm{kg}$ and increased with increasing distance downstream. The $\Sigma$ SEM-AVS $/ \mathrm{f}_{\mathrm{OC}}$ value for the background stream sediments from Schoolhouse Brook was $-160 \mu \mathrm{mol} / \mathrm{gOC}$, which was well within the no-effects range. In contrast, the $(\Sigma \mathrm{SEM}-\mathrm{AVS}) / \mathrm{f}_{\mathrm{OC}}$ for the sediments downstream of Ely Brook ranged from 281 to $395 \mu \mathrm{mol} / \mathrm{gOC}$, which falls within the uncertain effects range (USEPA, 2005).

\section{Bioassay Results}

For the Schoolhouse Brook samples, tests were conducted using Hyalella azteca for 28-day exposures and Chironomus dilutus for 12-day exposures and showed impairment downstream of the confluence with Ely Brook (table 8). For SB-3670M, the reference site, H. azteca had acceptable survival at $93.8 \pm 4.6$ percent, and growth of $3.31 \pm 0.06 \mathrm{~mm}$. At SB-2400M, survival dropped to $52.5 \pm 7.5$ percent, and growth was $2.43 \pm 0.11 \mathrm{~mm}$. At SB-1360M, survival rose slightly to $64.3 \pm 6.1$ percent, and growth was $2.53 \pm 0.11 \mathrm{~mm}$. The results from SB-140M, which was a field duplicate, are discussed below.

The midge (C. dilutus) results were somewhat different. Site SB-3670M, the reference, had unacceptable survival at $76.3 \pm 5.3$ percent, and growth was $1.00 \pm 0.05 \mathrm{~mm}$. 
At SB-2400M, survival was statistically identical at $80.0 \pm$ 4.2 percent, and growth dropped to $0.78 \pm 0.04 \mathrm{~mm}$. At SB$1360 \mathrm{M}$, survival dropped to $62.5 \pm 5.9$ percent, and growth rose to $1.28 \pm 0.08 \mathrm{~mm}$. The results from SB-140M, which was a field duplicate, are discussed below.

Moderate differences in results of toxicity tests between field duplicate sediment samples from the downstream site on Schoolhouse Brook [SB-140M and SB-140M(D)] were found. Three of the four endpoints (amphipod survival, midge survival, and midge growth) showed differences between tests ranging from 21 to 31 percent [relative percent difference (RPD), difference expressed as percent of mean]. The fourth endpoint, amphipod growth, was nearly identical between duplicate samples (RPD $=3$ percent). The observed differences were apparently not related to differences in physical or chemical constituents, which were generally within \pm 10 percent for these two samples (appendixes 3 and 4). The differences in midge survival between the SB-140M duplicates were less than the range observed for this endpoint across the three reference sites, apparently reflecting the overall high variability of this endpoint in this test. In contrast, differences in amphipod survival and midge growth between SB-140M and SB-140M(D) were substantially greater than the range of these endpoints among the reference sites but were comparable to the range of responses in the non-reference sites in Schoolhouse Brook. Because all three toxicity indices indicated similar, moderate risks of toxicity across sites SB-2400M, SB-1360M, SB-140Ma, and SB-140Mb (figs. 15 and 16), the high variation of metal toxicity responses in these sediments may reflect a natural increase in variation of these responses near the threshold for toxic effects.

\section{Relations among Trace Elements in Surface Water, Pore Water, Sediment, and Aquatic Biota}

Surface water, pore water, and sediment were sampled in August 2006, and invertebrates and fish were sampled in September 2006, to relate water and sediment quality to aquatic biota. Surface water, invertebrates, and fish were sampled at SB-140M, SB-1360M, SB-2400M, SB-3100M, and SB3670M. Pore water and sediment were sampled at SB-140M, SB-1360M, SB-2400M, and SB-3670M. Background conditions were characterized by samples obtained at SB-3670M.

HIs less than 1 were observed in water and sediments sampled at the background location (table 10). HI values for surface-water and sediment samples below the confluence with Ely Brook were greater than 1 mainly due to elevated copper concentrations (table 10). Pore-water samples below the confluence with Ely Brook, however, generally were less than 1 except for river meter 1,360, which had an HI of 1.5 due to elevated copper and zinc concentrations.

The RTH invertebrate assemblages sampled at the Schoolhouse Brook sites indicated severe impairment below the reference location SB-3670M and also that some degree of system recovery was occurring along a downstream gradient from the confluence of Ely Brook (that is, influx of contamination). The RTH assemblage data indicated that SB-3100M (below the Ely Brook confluence) was the location most severely impaired but that ecological condition of the stream had gradually improved by SB-140M (fig. 9C,D; table 9). However, the condition at SB-140M was still impaired compared to the reference location SB3670M, where invertebrate abundance was 14 times greater and richness was more than twice as great. Comparing the RTH assemblage data to the HIs indicated that invertebrate abundance and richness were closely associated with the metal concentrations in surface water (fig. 15C,D; table 9). The HIs for sites SB-3670M and SB-3100M were the lowest and highest respectively, with little difference in HIs among SB-2400M, SB-1360M, and SB-140M. The RTH assemblage data did indicate, however, that impairment among these three sites increased with proximity to the confluence of Ely Brook; this difference in the degree of impairment is likely related to higher contaminant concentrations in surface water from Ely Brook water during storm events that are diluted farther downstream.

Compared to the RTH assemblage data, the DTH data indicated a somewhat different response along the stream gradient. Whereas the RTH data indicated impairment was greatest below the Ely Brook confluence with incremental improvement sequentially downstream (fig. 9C,D; table 9), the DTH data indicated that impairment increased to SB-1360M, with partial recovery at SB-140M (fig. 10C,D; table 9). This difference between the RTH and DTH responses can be explained by the difference in the HI values for the Schoolhouse Brook sites. The highest HI for surface water occurred at SB-3100M, where the RTH assemblage also was the most impaired (fig. 15C,D; table 9), but the highest HI for pore water occurred at SB-1360M, where the DTH assemblage was the most impaired (fig. 16C,D; table 9). Comprehensively, these results indicate that a close association exists between biological assemblages and microhabitat conditions and that characterizing this association is crucial when making ecological assessments.

The assessment of the fish assemblages in Schoolhouse Brook, based on the fish IBI scores, essentially corresponded to the extent of impairment among sites based on the RTH invertebrate assemblages; impairment was severe below the confluence with Ely Brook, but with some recovery downstream (fig. 18A; table 9). The association between HI values for surface water and fish assemblages also was strong (fig. 19; table 9) and was similar to the response of the RTH invertebrate assemblages (fig. 15C,D; table 9). These results also imply a relation between the invertebrate and fish assemblages, which was indicated by a strong correlation between the fish IBI scores and the invertebrate richness values for Schoolhouse Brook (rho = 0.975). However, this relation does not indicate that the fish assemblage response in Schoolhouse Brook was dependent on the RTH invertebrate response; rather, the two assemblages were likely responding similarly to levels of metal toxicity. 

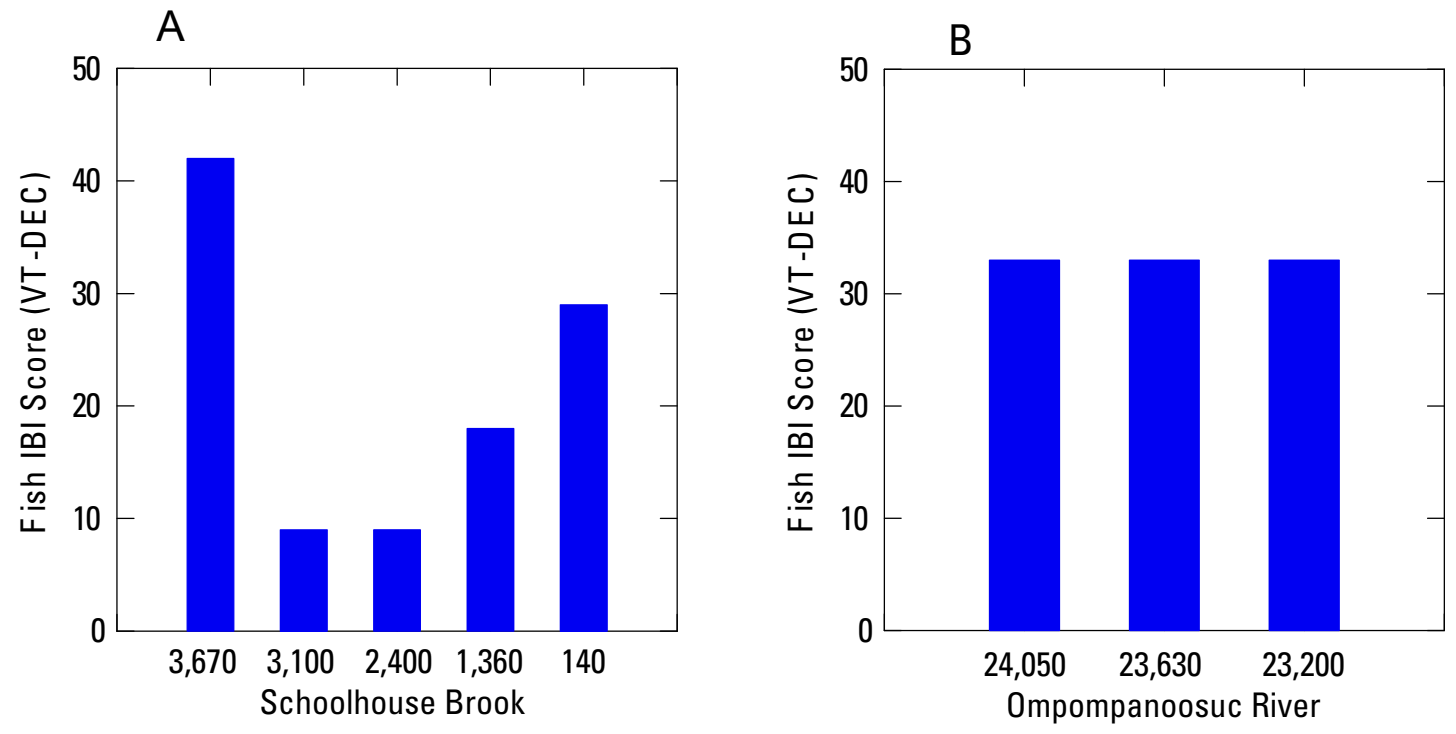

River Meter and Reach

Figure 18. Fish assemblage index of biotic integrity (IBI) scores for (A) Schoolhouse Brook and (B) the Ompompanoosuc River (Vermont Department of Environmental Conservation (VT-DEC) assessment criteria). The first location in each frame was used to represent background conditions for the stream.

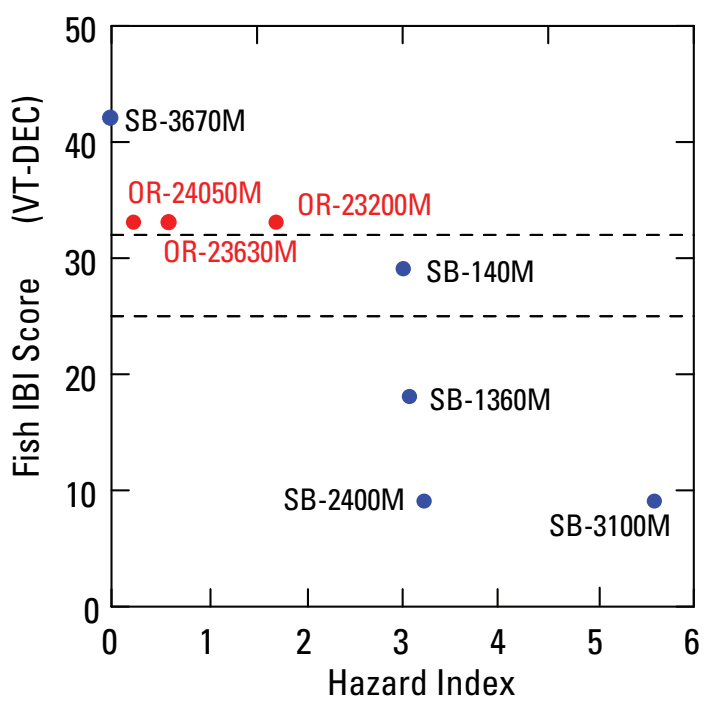

\section{Explanation}

SB-140M Sample location and indentifier

Figure 19. Fish assemblage index of biotic integrity (IBI) compared to the hazard index for surface waters. Upper dased line represents a threshold between an assessment of "Fair" and "Good"; the lower dashed line a threshold between "Fair" and Poor" (Vermont Department of Environmental Conservation (VT-DEC) assessment criteria). Blue symbols represent Schoolhouse Brook, and red symbols represent the Ompompanoosuc River. 
Analysis of the fish tissue data indicates that only copper and zinc were metals of potential concern when compared with the salmonid CBR values (Argue and others, 2008). The CBR value for copper was exceeded by more than three times in the single brook trout from SB-3100M (fig. 20A), and it is very likely that this fish had recently migrated to this location inadvertently from upstream, because no trout was captured farther downstream. Copper concentrations in the blacknose dace generally increased with distance downstream (fig. 20B), although fish at sites SB-3100M and SB-2400M also may have migrated from upstream. Only two blacknose dace were captured at each of these sites, and they were relatively mature fish of one size class (weight of 4.3 to 4.9 grams), whereas 41 dace were captured downstream at SB-140M and represented several size classes (average weight of 2.5 grams).

The zinc concentrations in fish tissue exceed the CBR value for that metal at all sites, and there were no discernable patterns of variance among the sites (fig. 20C,D). Although there were not enough samples for an explicit interpretation, the greater variance in $\mathrm{Cu}$ concentrations in both brook trout and blacknose dace suggests that $\mathrm{Cu}$ could be affecting fish more than $\mathrm{Zn}$ in Schoolhouse Brook.

\section{Ompompanoosuc River}

\section{Surface-Water Geochemistry}

Three sites were sampled in the Ompompanoosuc River in August 2006, one of which was upstream of the confluence with Schoolhouse Brook and was also discussed in the background conditions section (OR-24050M). The two other sites are site OR-23630M, located approximately $10 \mathrm{~m}$ downstream from the confluence with Schoolhouse Brook, and site OR-23200M, located farther downstream (approximately $440 \mathrm{~m}$ downstream from the confluence). Site OR-23200M is upstream of the confluence with Lake Fairlee outflow and the West Branch of the Ompompanoosuc River. Data from these sites will be used to examine downstream variations in water chemistry. Chemical constituents for surface-water samples are summarized in table 4, and complete analyses are reported in appendix 6.
A.

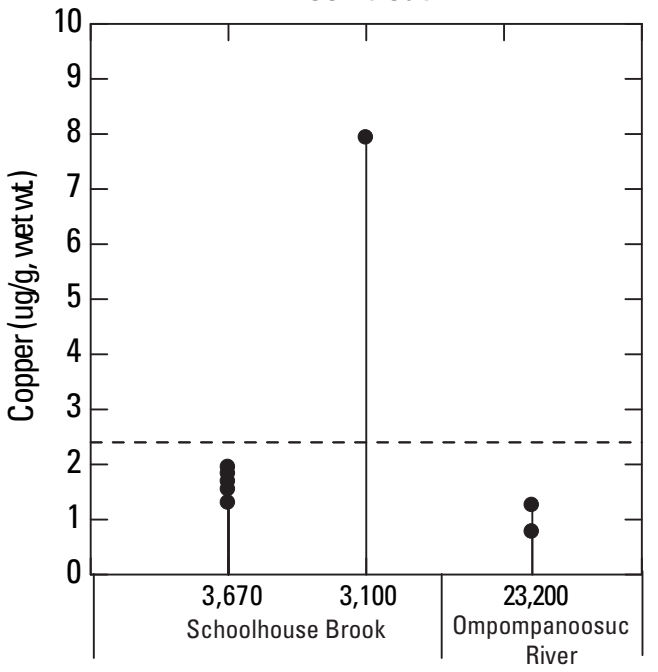

C. Brook trout

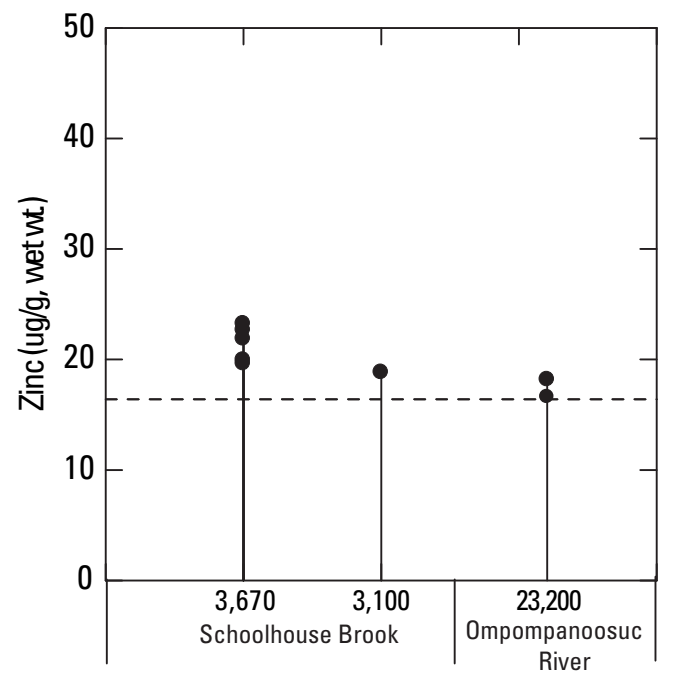

B.

Blacknose dace

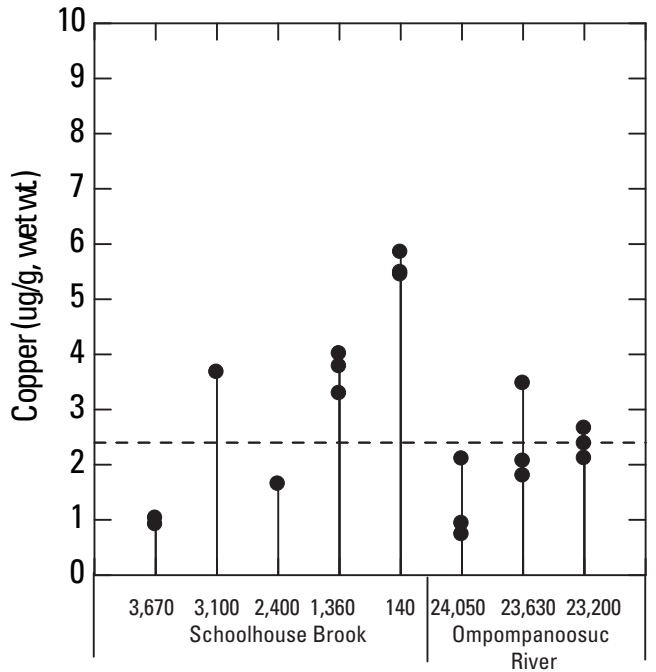

D.

Blacknose dace

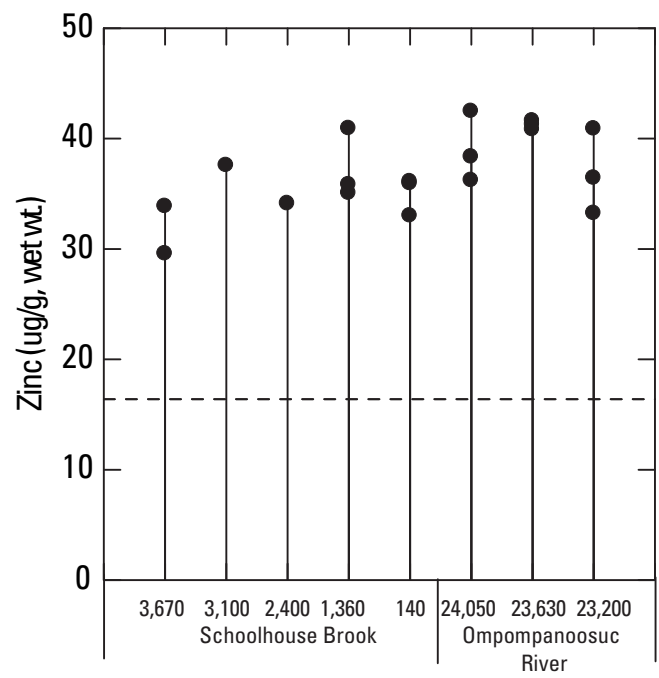

Figure 20. Concentrations of copper and zinc in brook trout and blacknose dace tissue compared to the critical body residue (CBR) values for salmonids. The CBR value for copper [2.4 micrograms per gram wet weight $(\mu \mathrm{g} / \mathrm{g}$, wet wt.)] is based on the effects level and for zinc (16.4 micrograms per gram wet weight) is based on the no-effects level (the effects level not reported for zinc). At each location, each dot represents a single fish sample for brook trout or a composite sample for blacknose dace. 


\section{Field Parameters and Major Inorganic Constituents}

The $\mathrm{pH}$ and specific conductance of surface waters from the Ompompanoosuc River did not vary significantly among samples; $\mathrm{pH}$ ranged from 8.0 to 8.1 , and specific conductance ranged from 196 to $198 \mu \mathrm{S} / \mathrm{cm}$ (fig. 5). The concentrations of the major dissolved cations also did not fluctuate considerably along the river reach sampled. For example, dissolved concentrations of Ca ranged from 32 to $32.9 \mathrm{mg} / \mathrm{L}, \mathrm{K}$ ranged from 2.16 to $2.24 \mathrm{mg} / \mathrm{L}, \mathrm{Mg}$ ranged from 1.46 to $1.61 \mathrm{mg} / \mathrm{L}$, and $\mathrm{Na}$ ranged from 5.15 to $5.45 \mathrm{mg} / \mathrm{L}$. Dissolved silica $\left(\mathrm{SiO}_{2}\right)$ only ranged from 7.2 to $7.8 \mathrm{mg} / \mathrm{L}$, and alkalinity, the dominant anionic species, only ranged from 85 to $87 \mathrm{mg} / \mathrm{L}$ (fig. 6). Chloride and sulfate were the next most abundant anionic species with concentrations of 5.4 to $6 \mathrm{mg} / \mathrm{L}$ and 7.2 to $8 \mathrm{mg} / \mathrm{L}$, respectively. Previous reports found similar results or contained similar data (Seal and others, 2001; Holmes and others, 2002; Argue and others, 2008).

\section{Iron, Aluminum, and Manganese}

The concentrations of dissolved aluminum and manganese increased from 13.4 to $44.6 \mu \mathrm{g} / \mathrm{L}$ and from 4.7 to $8.9 \mu \mathrm{g} / \mathrm{L}$, respectively, from background conditions at OR$24050 \mathrm{M}$ to the farthest downstream site at OR-23200M (fig. 7). The increase in concentrations from OR-24050M to OR-23630M was due to mixing of waters from Schoolhouse Brook which contained higher concentrations of these elements $(93.5 \mu \mathrm{g} / \mathrm{L}$ of $\mathrm{Al}$ and $13.6 \mu \mathrm{g} / \mathrm{L}$ of $\mathrm{Mn}$ at SB-140M). The concentrations of dissolved $\mathrm{Fe}$ are below the detection limit of $20 \mu \mathrm{g} / \mathrm{L}$ in all three samples.

\section{Minor and Trace Inorganic Elements}

The concentrations of several minor and trace elements, although generally low, increased from the background site of OR-24050M to the farthest downstream site of OR-23200M (fig. 7). These elements include $\mathrm{Cd}(<0.02$ to $0.1 \mu \mathrm{g} / \mathrm{L}), \mathrm{Co}$ $(<0.02$ to $0.31 \mu \mathrm{g} / \mathrm{L}), \mathrm{Cu}(0.84$ to $8.9 \mu \mathrm{g} / \mathrm{L})$, and $\mathrm{Pb}(0.08$ to $0.2 \mu \mathrm{g} / \mathrm{L})$. The concentrations of dissolved zinc increased from $9.3 \mu \mathrm{g} / \mathrm{L}$ (OR-24050M) to $12.5 \mu \mathrm{g} / \mathrm{L}$ (OR-23630M) and then decreased to $6.9 \mu \mathrm{g} / \mathrm{L}$ (OR-23200M). The concentrations of $\mathrm{Ba}$ (19.1 to $20.2 \mu \mathrm{g} / \mathrm{L}), \operatorname{Sr}(138$ to $139 \mu \mathrm{g} / \mathrm{L})$, and $\mathrm{U}(0.24 \mu \mathrm{g} / \mathrm{L})$ did not vary significantly among samples. Dissolved Ag, As, $\mathrm{Be}, \mathrm{Cr}, \mathrm{Hg}, \mathrm{Sb}, \mathrm{Se}, \mathrm{Tl}$, and $\mathrm{V}$ concentrations were all below their detection limits. Concentrations of dissolved nickel were near or below its detection limit.

\section{Dissolved Organic Carbon and Nutrients}

DOC concentrations throughout the Ompompanoosuc River were nearly constant (2.5 to $2.6 \mathrm{mg} / \mathrm{L}$ ) and slightly higher than that of Schoolhouse Brook. Nutrients were generally low throughout the study area. Total dissolved nitrogen was $0.2 \mathrm{mg} / \mathrm{L}$, and total dissolved phosphorus ranged from 0.005 to $0.007 \mathrm{mg} / \mathrm{L}$.

\section{Trace-Element Loads}

Coupled streamflow measurements and surface-water samples obtained at OR-23200M, OR-23630M, and OR$24050 \mathrm{M}$ on August 21, 2006, were used to describe the attenuation of constituents in the Ompompanoosuc River. Background conditions were characterized by samples obtained at OR-24050M.

Most constituent loads at OR-23630M were similar to those expected from a summation of loads for SB-140M and OR-24050M (fig. 13). However, loads for total $\mathrm{Al}, \mathrm{Co}, \mathrm{Cu}$, and $\mathrm{Fe}$ and dissolved $\mathrm{Co}$ and $\mathrm{Cu}$ at $\mathrm{OR}-23630 \mathrm{M}$ were less than expected assuming simple mixing. This is most likely the result of Fe hydroxides settling to the river bottom as waters travel from the steep gradient of Schoolhouse Brook to the more tranquil Ompompanoosuc River, as reflected by the higher Fe concentrations in the Ompompanoosuc sediments downstream of the confluence with Schoolhouse Brook (table 6).

Iron and manganese oxidation in the surface water and reductive dissolution in the hyporheic zone of the streambed are most likely driving the fate and transport of constituents in the Ompompanoosuc River from OR-23630M to OR23200M. AVS was not detected in the streambed sediments, and sulfate loads were similar between locations. Loads for total and dissolved $\mathrm{Cd}, \mathrm{Co}, \mathrm{Cu}$, total $\mathrm{Fe}$, and dissolved $\mathrm{Mn}$ increased, and loads for total Mn decreased from OR-23630M to OR-23200M. Transient flow through the streambed may induce cycling of $\mathrm{Fe}$ and $\mathrm{Mn}$ hydroxides and the release of associated metals as $\mathrm{O}_{2}$ or $\mathrm{NO}_{3}$ infiltrates to reduced sections of the hyporheic zone (Koretsky and others, 2006). This also may be evident as manganese concentrations in the pore water were elevated, as is typical at the boundary of the anoxic layer (Koretsky and others, 2006). Transient flow through the streambed that diffuses upward most likely results in reprecipitation of Fe and Mn hydroxides, whereas flow diffusing downward to more reduced sediments most likely results in Fe being associated with the sulfides and Mn being associated with carbonates (Koretsky and others, 2006).

\section{Comparisons with Ambient Water-Quality Criteria and Relations among Reaches}

The Ompompanoosuc River was partitioned into three reaches for analysis of water data on the basis of the proximity to runoff associated with the Ely Mine site and the confluence with a tributary. Stream reach 1 , defined by locations sampled from river meter 8,350 to 20,000 , is a fourth-order stream reach (table 2) and was partitioned to describe waterquality conditions above the confluence with the West Branch Ompompanoosuc River and below the confluence with the Lake Fairlee outflow tributary. Stream reach 2, defined by locations sampled from river meter 20,000 to 23,640 , is a third-order stream reach and was partitioned to describe water-quality conditions downstream of the confluence with Schoolhouse Brook and above the Lake Fairlee outflow tributary. Stream reach 3, defined by locations sampled above river meter 23,640, was partitioned to describe background conditions. 
Concentrations in surface waters greater than AWQC were observed in stream reach 1 for $\mathrm{Al}, \mathrm{Ba}, \mathrm{Mn}$, and $\mathrm{Ag}$, and in stream reach 2 for $\mathrm{Al}, \mathrm{Ba}, \mathrm{Cu}$, and $\mathrm{Hg}$ (fig. 21, appendix 5). Concentrations of most elements in surface waters of reaches 1 and 2 generally were similar to background conditions (rho > 0.05). However, concentrations of $\mathrm{Co}, \mathrm{Cu}$, and $\mathrm{Mn}$ in reach 1 and $\mathrm{Cd}, \mathrm{Co}$, and $\mathrm{Cu}$ in reach 2 generally were greater than and significantly different from background conditions (rho $<0.05$ ). Concentrations of $\mathrm{Co}$ and $\mathrm{Cu}$ in reach 1 generally were less than and significantly different from those observed in reach 2 (rho $<0.05)$.

\section{Pore-Water Geochemistry}

Pore-water samples from the Ompompanoosuc River were collected from the background conditions site OR$24050 \mathrm{M}$ and farthest downstream site OR-23200M. Pore water was not collected at OR-23630M, which was $10 \mathrm{~m}$ downstream of the confluence with Schoolhouse Brook. Chemical constituents for pore-water samples are summarized in table 5, and complete analyses are reported in appendix 7.

\section{Field Parameters and Major Inorganic Constituents}

The $\mathrm{pH}$ and specific conductance were measured only on the in situ and equilibrated samples. The $\mathrm{pH}$ of pore waters from the Ompompanoosuc River was near neutral and ranged from 7.4 to 7.9 (fig. 5). This is comparable to the $\mathrm{pH}$ of the pore waters from Schoolhouse Brook upstream from its mouth (SB-140M). The differences in $\mathrm{pH}$ between the in situ and equilibrated pore waters were not significant. In contrast to $\mathrm{pH}$, the specific conductance values of the equilibrated pore water ( 535 to $709 \mu \mathrm{S} / \mathrm{cm}$ ) were significantly higher than the in situ splits (277 to $359 \mu \mathrm{S} / \mathrm{cm}$ ), which were higher than surface-water values (196 to $198 \mu \mathrm{S} / \mathrm{cm}$ ) (fig. 5).

Calcium was the dominant dissolved cation, and $\mathrm{K}$, $\mathrm{Mg}, \mathrm{Na}$, and $\mathrm{SiO}_{2}$ occurred in subequal proportions, similar to the surface-water samples. The concentrations of most of these constituents were lower in pore waters from the site downstream of the confluence with Schoolhouse Brook (OR-23200M) compared to the upstream background site (OR-24050M). The concentrations of dissolved major cations were usually highest in the equilibrated samples and lowest in the in situ samples, with the intermediate concentrations in centrifuged splits (table 5). Dissolved cation concentrations reached $137 \mathrm{mg} / \mathrm{L}$ for $\mathrm{Ca}, 12.9 \mathrm{mg} / \mathrm{L}$ for $\mathrm{K}, 7.78 \mathrm{mg} / \mathrm{L}$ for $\mathrm{Mg}$, $16.8 \mathrm{mg} / \mathrm{L}$ for $\mathrm{Na}$, and $16.1 \mathrm{mg} / \mathrm{L}$ for $\mathrm{SiO}_{2}$. Hardness ranged from 95.5 to $141.3 \mathrm{mg} / \mathrm{L} \mathrm{CaCO}_{3}$ equivalent in the in situ samples, from 186.6 to $187.9 \mathrm{mg} / \mathrm{L}$ in centrifuged samples, and from 233.6 to $374.4 \mathrm{mg} / \mathrm{L}$ in equilibrated samples. Alkalinity was the dominant anionic species; sulfate and chloride concentrations were significantly less and occurred in subequal proportions (fig. 6).
Iron, Aluminum, and Manganese

Dissolved iron concentrations were below the detection limit of $20 \mu \mathrm{g} / \mathrm{L}$ for in situ and equilibrated pore waters; the concentrations in the centrifuged samples were 30 and $23 \mu \mathrm{g} / \mathrm{L}$ for OR-24050M and OR-23200M, respectively (fig. 7). The concentrations of dissolved aluminum were also low and reached $38.5 \mu \mathrm{g} / \mathrm{L}$ in the centrifuged pore water from site OR-23200M. Dissolved Mn concentrations were significantly higher than $\mathrm{Al}$ and $\mathrm{Fe}$ concentrations and reached $327 \mu \mathrm{g} / \mathrm{L}$ in the in situ pore waters, $1,500 \mu \mathrm{g} / \mathrm{L}$ in centrifuged pore waters, and $6,270 \mu \mathrm{g} / \mathrm{L}$ in equilibrated pore waters. Aluminum and manganese were not determined on centrifuged pore waters due to insufficient sample size.

\section{Minor and Trace Inorganic Elements}

The minor and trace elements present in pore waters from the Ompompanoosuc River were Ba (up to $126 \mu \mathrm{g} / \mathrm{L}$ ), Cd (up to $0.19 \mu \mathrm{g} / \mathrm{L}$ ), Co (up to $3.08 \mu \mathrm{g} / \mathrm{L}$ ), Cr (up to $1.9 \mu \mathrm{g} / \mathrm{L}$ ), Cu (up to $19.1 \mu \mathrm{g} / \mathrm{L}$ ), Ni (up to $3.8 \mu \mathrm{g} / \mathrm{L}$ ), $\mathrm{Pb}$ (up to $0.3 \mu \mathrm{g} / \mathrm{L}$ ), Se (up to $1.2 \mu \mathrm{g} / \mathrm{L}$ ), $\mathrm{Sr}$ (up to $559 \mu \mathrm{g} / \mathrm{L}$ ), U (up to $1.91 \mu \mathrm{g} / \mathrm{L}$ ), V (up to $1.8 \mu \mathrm{g} / \mathrm{L}$ ), and $\mathrm{Zn}$ (up to $5.7 \mu \mathrm{g} / \mathrm{L}$ ). The highest concentrations of these elements were commonly found in the equilibrated pore waters, and the lowest concentrations were commonly found in the in situ pore waters. The concentrations of $\mathrm{Cd}, \mathrm{Co}, \mathrm{Cu}$, and $\mathrm{Pb}$ were higher in pore waters downstream of the confluence with Schoolhouse Brook (OR-23200M) compared to upstream (OR-24050M) (fig. 7). Similar to surface waters, dissolved $\mathrm{Ag}, \mathrm{As}, \mathrm{Be}, \mathrm{Hg}$, $\mathrm{Sb}$, and $\mathrm{Tl}$ concentrations in all pore waters were below their detection limits.

\section{Dissolved Organic Carbon and Nutrients}

DOC and nutrient concentrations were determined only on splits of the in situ pore-water samples. DOC concentrations were $1.4 \mathrm{mg} / \mathrm{L}$ in both OR-24050M and OR-23200M pore waters. Nutrients were low, with total dissolved nitrogen values of $1.04 \mathrm{mg} / \mathrm{L}$ for OR-24050M and $0.2 \mathrm{mg} / \mathrm{L}$ for OR$23200 \mathrm{M}$, and total dissolved phosphorus of $0.006 \mathrm{mg} / \mathrm{L}$ for OR-24050M and $0.005 \mathrm{mg} / \mathrm{L}$ for OR-23200M.

\section{Comparisons with Ambient Water Quality Criteria}

In the previous section on surface water in the Ompompanoosuc River, sample sites were divided on the basis of stream reach and compared to ambient water-quality criteria. Hardness-dependent criteria were calculated based on the hardness of the sample. This section will refer to the same stream reaches although pore waters are from this study whereas surface waters included all historical samples. Pore waters were not sampled prior to this investigation. As in the previous section, stream reach 2 refers to water-quality conditions downstream from the confluence with Schoolhouse Brook and upstream from the confluence with Lake Fairlee outflow; OR-23200M is from this reach. Stream reach 3 refers to water-quality conditions upstream of the confluence with Schoolhouse Brook and represents background concentrations; 

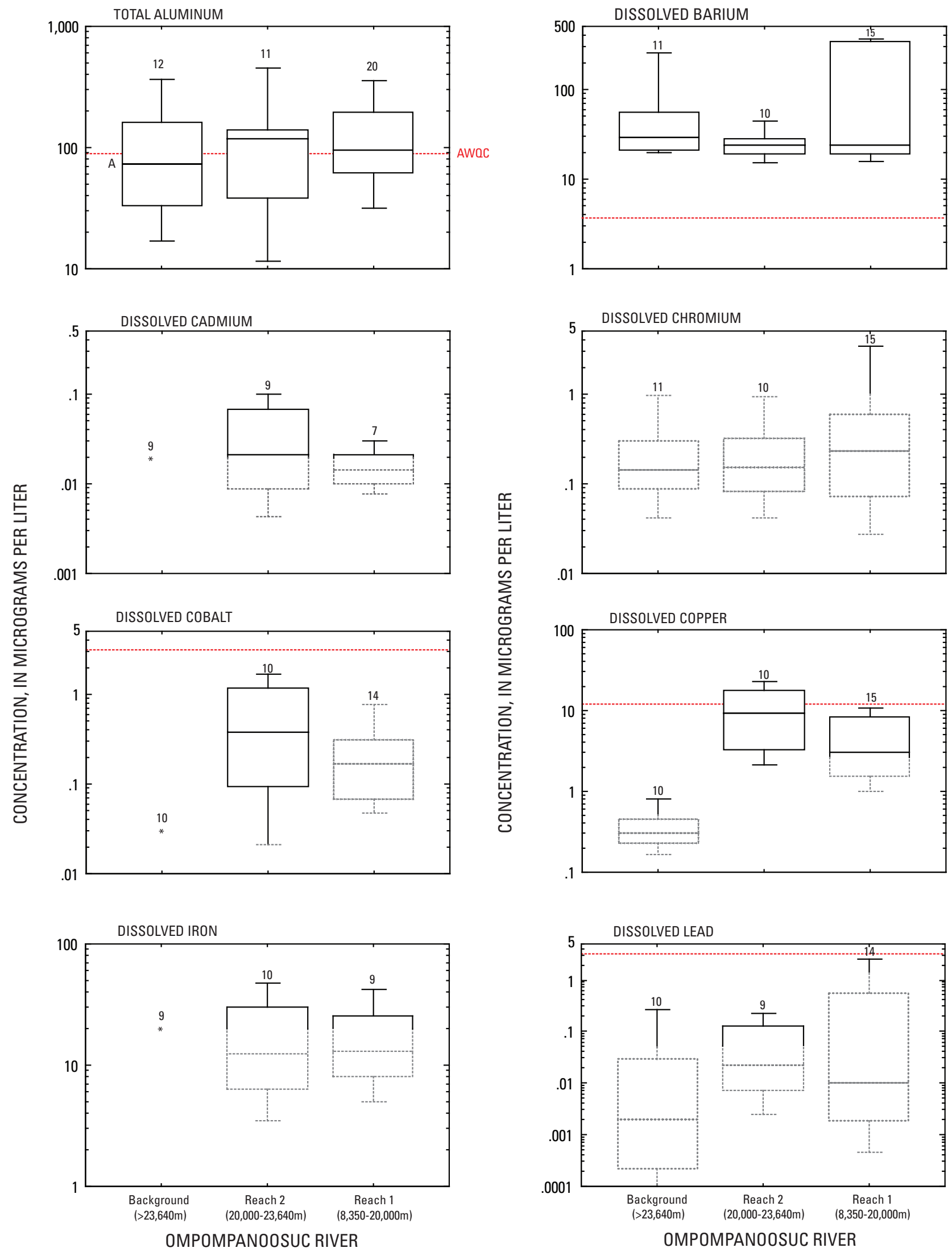

Figure 21. Select constituent concentrations in surface waters among three reaches in the Ompompanoosuc River at the Ely Mine Superfund site, Vershire, VT. Data are from this study and Argue and others (2008). 

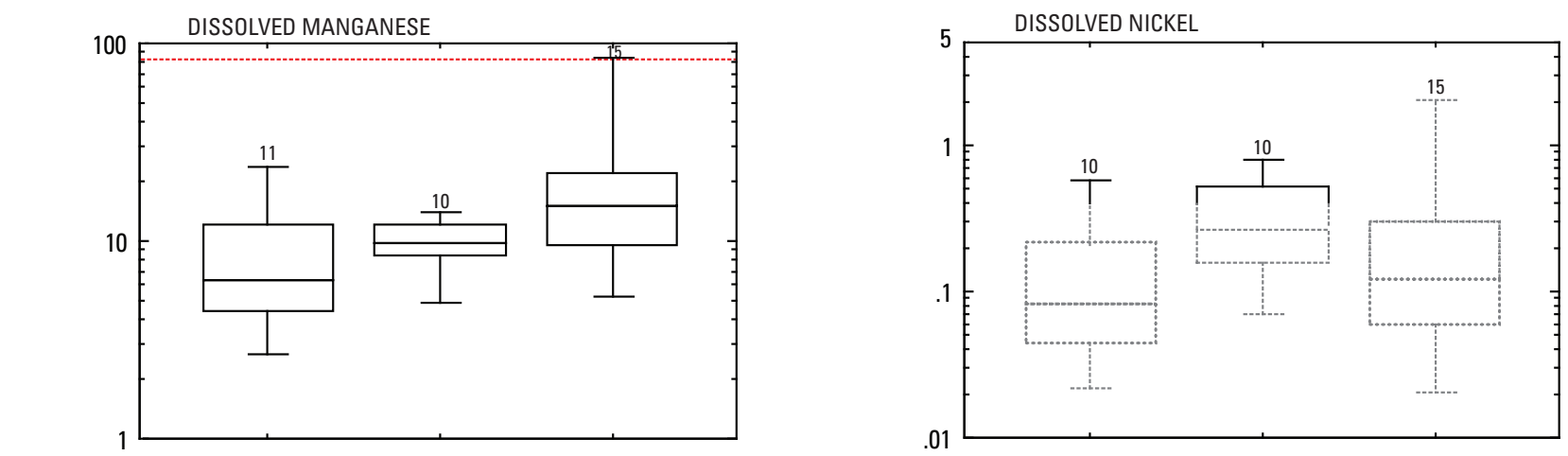

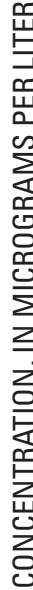

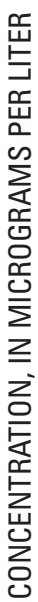
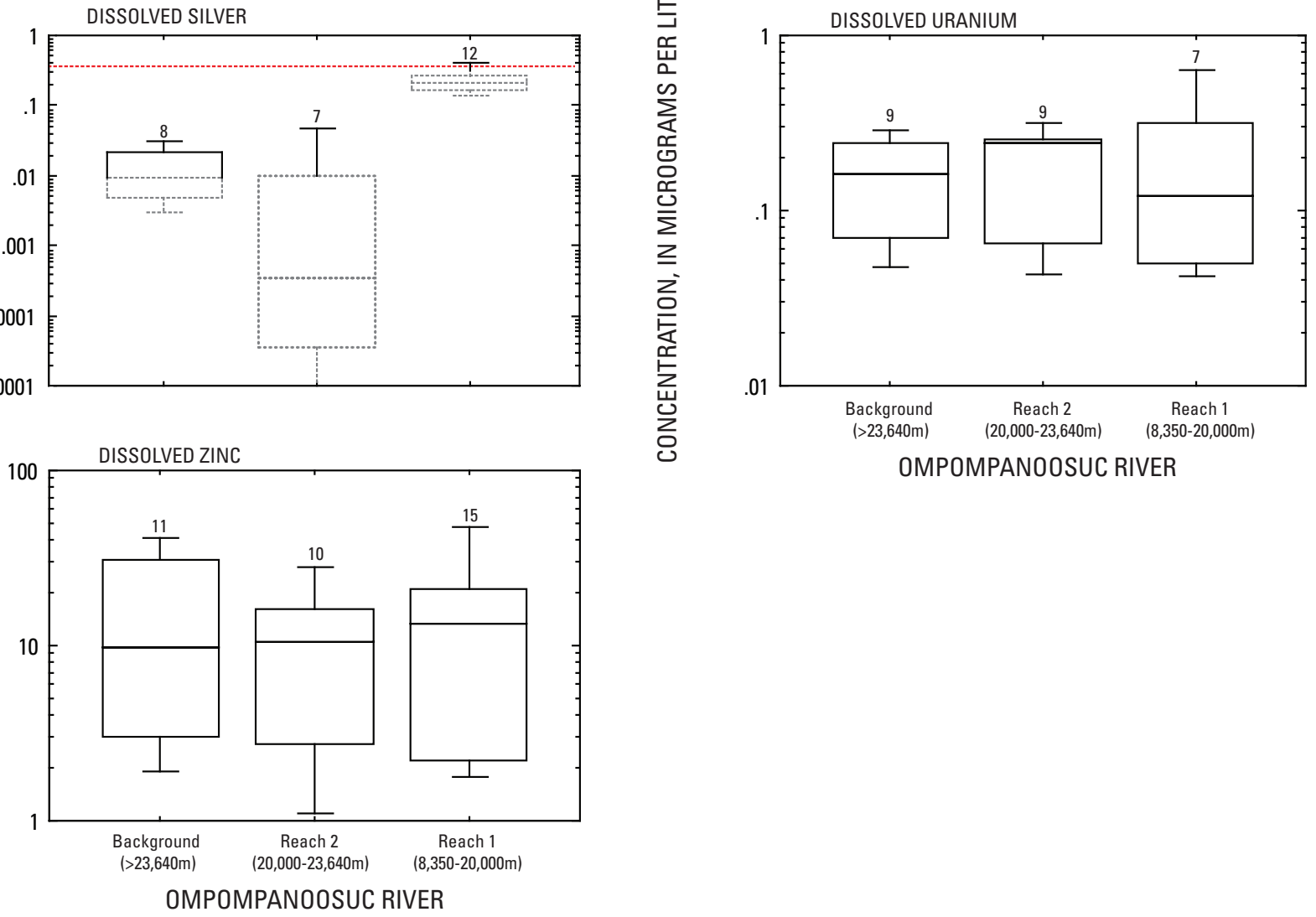

\section{EXPLANATION}

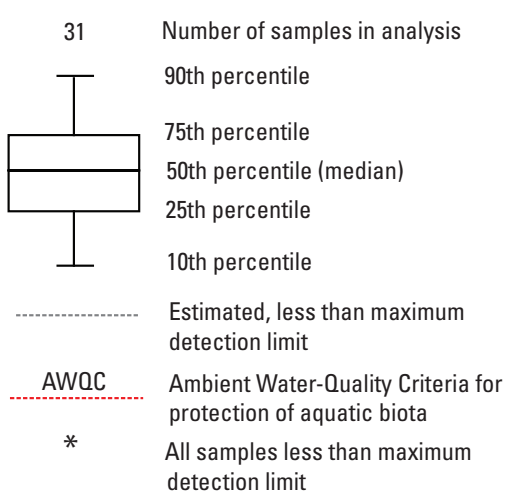

Figure 21. Select constituent concentrations in surface waters among three reaches in the Ompompanoosuc River at the Ely Mine Superfund site, Vershire, VT. Data are from this study and Argue and others (2008).-Continued 
OR-24050M is from this reach. Pore waters were not collected in stream reach 1 , which is downstream of the confluence with Lake Fairlee outflow and upstream of the confluence with the West Branch of the Ompompanoosuc River.

The concentrations of barium and manganese in pore waters in stream reaches 2 and 3 exceeded the AWQC of 3.8 and $80.3 \mu \mathrm{g} / \mathrm{L}$, respectively. Uranium is the only other element in the background conditions sample (reach 3) which exceeded (only minimally) its water-quality criteria of $1.87 \mu \mathrm{g} / \mathrm{L}$; the concentrations of uranium in the equilibrated pore water was $1.91 \mu \mathrm{g} / \mathrm{L}$. Similar to uranium, the concentration of dissolved cobalt in the centrifuged pore water barely exceeded its AWQC of $3.06 \mu \mathrm{g} / \mathrm{L}$ with a concentration of $3.08 \mu \mathrm{g} / \mathrm{L}$. The only other elemental exceedance was $\mathrm{Cu}$ in the equilibrated pore water of sample OR-23200M with a concentration of $19.1 \mu \mathrm{g} / \mathrm{L}$.

\section{Sediment Geochemistry}

Sediment samples from the Ompompanoosuc River were collected from the background conditions site OR-24050M and farthest downstream site OR-23200M. The majorelement geochemistry of the sediment samples reflects their siliciclastic constituents. Chemical constituents for sediment samples are summarized in table 6, and complete analyses are reported in appendix 8. SEM-AVS data for sediment samples are summarized in table 7, and complete analyses are reported in appendix 4. Aluminum ranged from 3.27 to 3.54 weight percent, Fe from 1.4 to 2.28 weight percent, and $\mathrm{Ca}$ from 1.13 to 1.3 weight percent. $\mathrm{Mg}, \mathrm{K}$, and $\mathrm{Na}$ occurred in subequal proportions with concentrations that ranged from 0.71 to 0.84 weight percent. In general, the order of abundance of elements in the sediments was the following: $\mathrm{Al}>\mathrm{Fe}>$ $\mathrm{Ca}>\mathrm{K}>\mathrm{Na}>\mathrm{Mg}$. Of these elements, only $\mathrm{Al}, \mathrm{Fe}$, and $\mathrm{Ca}$ increased significantly downstream from the confluence with Schoolhouse Brook (SB-2400M) compared to the background sample site (OR-24050). Sulfur did not vary significantly and ranged from 0.02 to 0.03 weight percent. Carbonate carbon was low ( 0.04 to 0.05 weight percent $C)$, and total organic carbon was considerably higher in comparison ( 0.25 to 0.37 weight percent).

Maximum concentrations of trace elements in the Ompompanoosuc River sediments are $5 \mathrm{mg} / \mathrm{kg}$ for As (OR$23200 \mathrm{M}), 195 \mathrm{mg} / \mathrm{kg}$ Ba (OR-23200M), $8.1 \mathrm{mg} / \mathrm{kg} \mathrm{Co}$ (OR-23200M), $37 \mathrm{mg} / \mathrm{kg} \mathrm{Cr}(\mathrm{OR}-24050 \mathrm{M}), 76.7 \mathrm{mg} / \mathrm{kg} \mathrm{Cu}$ (OR-23200M), 1,120 mg/kg Mn (OR-23200M), $0.5 \mathrm{mg} / \mathrm{kg} \mathrm{Mo}$ (OR-23200M), $11.7 \mathrm{mg} / \mathrm{kg}$ Ni (OR-24050M), $10.4 \mathrm{mg} / \mathrm{kg} \mathrm{Pb}$ (OR-23200M), $0.22 \mathrm{mg} / \mathrm{kg} \mathrm{Sb}(\mathrm{OR}-23200 \mathrm{M}), 198 \mathrm{mg} / \mathrm{kg} \mathrm{Sr}$ (OR-24050M), and $53 \mathrm{mg} / \mathrm{kg} \mathrm{Zn}$ (OR-23200M). The concentrations of $\mathrm{Co}, \mathrm{Cu}, \mathrm{Mn}, \mathrm{Mo}$, and $\mathrm{Zn}$ were significantly higher in the downstream sediment sample (OR-23200M) compared to the background sample site (OR-24050M). Ag, Cd, Hg, and Se were near or below their detection limits.

Acid volatile sulfide for the stream-sediment samples from the Ompompanoosuc River was below the detection limit of $23 \mathrm{mg} / \mathrm{kg}(0.7 \mu \mathrm{mol} / \mathrm{g})$. The sum of the concentrations of simultaneously extracted metals $(\mathrm{Cd}+\mathrm{Cu}+\mathrm{Pb}+\mathrm{Ni}+\mathrm{Zn})$ were low with $0.2 \mu \mathrm{mol} / \mathrm{g}$ for sediment from the background site (OR-24050M) and $0.4 \mu \mathrm{mol} / \mathrm{g}$ for the downstream site (OR-23200M). Simultaneously extracted $\mathrm{Cd}$ and $\mathrm{Hg}$ were below their detection limits.

The concentrations of $\mathrm{As}, \mathrm{Cd}, \mathrm{Cr}, \mathrm{Cu}, \mathrm{Hg}, \mathrm{Ni}, \mathrm{Pb}$, and $\mathrm{Zn}$ in the sediments from Ompompanoosuc River are below the PEC limits. The $\Sigma$ SEM-AVS $) / f_{O C}$ values for the sediments were -140 (OR-24050M) and -95 (OR-23200M) $\mu$ moles/gOC, which were well within the no-effects range (USEPA, 2005).

\section{Bioassay Results}

For the Ompompanoosuc River samples, tests showed no impairment downstream of the confluence with Schoolhouse Brook (table 8). For OR-24050M, the reference site, $H$. azteca had acceptable survival at $93.8 \pm 6.5$ percent, and growth of $3.21 \pm 0.02 \mathrm{~mm}$. At OR-23200M, survival was $91.3 \pm 3.0$ percent, and growth was $3.17 \pm 0.01 \mathrm{~mm}$. The midge (C. dilutus) results were similar. Site OR-24050M, the reference, had acceptable survival at $90.0 \pm 1.9$ percent, and growth was $1.06 \pm 0.08 \mathrm{~mm}$. At OR-23200M, survival was $83.8 \pm 6.0$ percent, and growth was $0.96 \pm 0.14 \mathrm{~mm}$.

\section{Relations among Trace Elements in Surface Water, Pore Water, Sediment, and Aquatic Biota}

Surface water, pore water, and sediment were sampled in August 2006, and invertebrates and fish were sampled in September 2006 to relate water and sediment conditions to aquatic biota. Surface water, invertebrates, and fish were sampled at OR-23200M, OR-23630M, and OR-24050M. Pore-water and sediment samples were obtained at OR-23200M and OR-24050M. Background conditions were characterized by samples obtained at OR-24050M.

HIs less than 1 were observed for all water and sediments sampled except for the surface waters sampled at OR23200M, which had a HI of 1.7 (table 10). An HQ value of 0.1 was observed for $\mathrm{Cu}$ in surface water at OR-23200M.

The RTH and DTH invertebrate data indicated that there may be some impairment to the Ompompanoosuc River caused by acid-rock drainage coming from Schoolhouse Brook. From sites OR-24050M to OR-23200M, RTH abundance declined by 33 percent, and richness declined by 40 percent (fig. $9 E, F$ ). No DTH sample was collected at the OR-23630M location, but comparing OR-24050M with OR$23200 \mathrm{M}$ indicated that invertebrate abundance decreased by 58 percent and richness decreased by 19 percent (fig. $10 E, F$ ). Both the RTH and DTH responses were associated with increases in the HIs for surface water (fig. 15E,F; table 9) and pore water (fig. 16E,F; table 9), respectively, although the only $\mathrm{HI}$ to exceed 1.0 was at OR-23200M $(\mathrm{HI}=1.7)$. Compared to the RTH assemblages, the relatively less impairment in the DTH assemblages from OR-24050M to OR-23200M could perhaps be associated by the low $\mathrm{HI}$ for pore water at OR-23200M $(\mathrm{HI}=0.9)$. Even the sediments at OR-23200M were relatively uncontaminated $(\mathrm{HI}=0.9)$; among all the 
non-reference sites sampled for pore water or sediment in the study, the respective HIs at OR-23200M were the lowest.

The assessment of the fish assemblages in Ompompanoosuc River did not clearly indicate that any degree of impairment was caused by acid-mine drainage from Schoolhouse Brook. The IBI value derived for the assemblages at all three sites was 33 (fig. 18B; table 9), which was the minimal score for a bioassessment classification of "good" by the VTDEC (2008). The assessment at OR-23200M was based on data from the survey that was conducted in 2007. Based on the fish assemblage data from the original 2006 survey, the OR-23200M was assessed as "poor," but of the eight metrics used to derive the fish IBI, only density of individuals failed. The fish resurvey was done 1 year later (within 1 day), and the number of fish captured was exactly twice the number from the original survey (124 and 62, respectively). In comparing the fish IBI values with surface-water HIs among all locations, the Ompompanoosuc locations were between SB-3670M $(\mathrm{HI}=0, \mathrm{IBI}=42)$ and SB-140M $(\mathrm{HI}=3.0, \mathrm{IBI}=29)$, as might be predicted (fig. 19).

Only two brook trout were captured on the Ompompanoosuc River for a tissue sample, and both were at location OR-23200M. Both samples of trout had $\mathrm{Cu}$ concentrations below the $\mathrm{Cu} \mathrm{CBR}$ value and had $\mathrm{Zn}$ concentrations only slightly above the Zn CBR value (fig. 20A,C). However, the zinc concentrations were still less than zinc values in the five fish from the reference location (SB-3670M). The concentrations of $\mathrm{Cu}$ in blacknose dace increased somewhat in the Ompompanoosuc River below Schoolhouse Brook, as based on the average concentration in the three composite samples from each location. The average concentration was $1.3 \mathrm{mg} / \mathrm{kg}$ at OR-24050M and $2.4 \mathrm{mg} / \mathrm{kg}$ at both OR-23630M and OR23200M; however, even these averages were only equal to the CBR value for copper (fig. 20B). As seen in the Schoolhouse Brook sites, concentrations of zinc in blacknose dace showed no discernible pattern among the Ompanoosuc River sites, even though all samples were well above the CBR level for $\mathrm{Zn}$ (fig. 20D).

\section{Discussion}

The health of the aquatic ecosystem surrounding the Ely Mine Superfund site has been assessed by investigating ecological indicators of aquatic ecosystem health and then by examining geochemical attributes of associated water and sediments to explain the biological observations. Ecological indicators used in this study include parameters for both invertebrates and fish. Invertebrate measures include infauna and epifauna invertebrate assemblage abundance and richness data. The fish community was assessed using an index of biotic integrity.

Several approaches are available to evaluate the potential toxicity of both the surface water and sediment. Surfacewater toxicity can be evaluated on the basis of hardness-based criterion maximum concentration (CMC) values for acute toxicity and criterion continuous concentration (CCC) values of $\mathrm{Ag}, \mathrm{Cd}, \mathrm{Cu}, \mathrm{Cr}(\mathrm{III}), \mathrm{Ni}, \mathrm{Pb}$, and $\mathrm{Zn}$ (USEPA, 2006). Copper toxicity can also be evaluated on the basis of a water-quality criterion that incorporates the role of DOC through the Biotic Ligand Model (USEPA, 2007). Sediment toxicity can be evaluated through comparison of concentrations of As, $\mathrm{Cd}, \mathrm{Cr}$, $\mathrm{Cu}, \mathrm{Hg}, \mathrm{Ni}, \mathrm{Pb}$, and $\mathrm{Zn}$ with a probable effects concentration (PEC; MacDonald and others, 2000). It can also be evaluated in terms of an equilibrium-partitioning sediment benchmark (ESB; USEPA, 2005) that combines $\mathrm{Cd}, \mathrm{Cu}, \mathrm{Ni}, \mathrm{Pb}$, and $\mathrm{Zn}$. Sediment toxicity can be evaluated additionally using porewater concentrations relative to water-quality standards. This study used three separate approaches to investigate porewater compositions. Sediment toxicity has also been assessed in this study through toxicity testing employing Hyalella azteca with 28-day exposures and Chironomus dilutus with 10-day exposures.

\section{Surface-Water Quality}

Surface-water chemistry throughout the site was dominated by streams of moderate alkalinity and hardness that become impacted from the influx of acid-mine drainage in and around the mine-waste piles, which was then followed by progressive dilution by larger streams of moderate alkalinity and hardness downstream of the site. Surface water in Ely Brook and tributary 2 in Ely pond 1 started with neutral $\mathrm{pH}$ (7.0 to 7.2 ), low specific conductance (51 to $87 \mu \mathrm{S} / \mathrm{cm}$ ), low hardness (18.8 to $38.3 \mathrm{mg} / \mathrm{L} \mathrm{CaCO}_{3}$ ), moderate alkalinity (19 to $41 \mathrm{mg} / \mathrm{L} \mathrm{CaCO}_{3}$ equivalent), and low DOC (1.9 to $3.5 \mathrm{mg} / \mathrm{L}$ ). Ely Brook showed only modest variations in $\mathrm{pH}$ and increases in specific conductance from EB-1080M to EB-600M prior to reaching the area of the mine-waste piles and before its confluence with tributary 2 , which drains the ponds. Through this same reach, alkalinity decreased from $41 \mathrm{mg} / \mathrm{L} \mathrm{CaCO}_{3}$ to 0 , dissolved sulfate concentrations increased modestly up to $52 \mathrm{mg} / \mathrm{L}$, dissolved Fe was near the detection limit $(20 \mu \mathrm{g} / \mathrm{L})$, dissolved Al reached $25.1 \mu \mathrm{g} / \mathrm{L}$, dissolved $\mathrm{Cd}$ reached $1.0 \mu \mathrm{g} / \mathrm{L}$, dissolved $\mathrm{Cu}$ reached $837 \mu \mathrm{g} / \mathrm{L}$, and dissolved $\mathrm{Zn}$ reached $114 \mu \mathrm{g} / \mathrm{L}$.

Tributary 2 underwent significant changes in water chemistry prior to merging with Ely Brook, with the most dramatic changes taking place between Ely ponds 4 and 5. The $\mathrm{pH}$ dropped from 7.0 to 6.5 in pond 5 and to 4.7 in Ely pond 6. Likewise, the specific conductance increased from 51 to $117 \mu \mathrm{S} / \mathrm{cm}$ in pond 5 to $206 \mu \mathrm{S} / \mathrm{cm}$ in pond 6 . Through this same reach, alkalinity reached a high of $31 \mathrm{mg} / \mathrm{L} \mathrm{CaCO}_{3}$ but decreased to $17 \mathrm{mg} / \mathrm{L}$ and then 0 , hardness increased to $63.6 \mathrm{mg} / \mathrm{L} \mathrm{CaCO}_{3}$, dissolved sulfate concentrations increased from $6.3 \mathrm{mg} / \mathrm{L}$ in pond 1 to $33 \mathrm{mg} / \mathrm{L}$ in pond 5 and $93 \mathrm{mg} / \mathrm{L}$ in Ely pond 6. Dissolved iron and aluminum concentrations were less systematic. The dissolved iron concentration in the reference pond was $66 \mu \mathrm{g} / \mathrm{L}$, reached $353 \mu \mathrm{g} / \mathrm{L}$ in pond 2 , dropped to $<20 \mu \mathrm{g} / \mathrm{L}$ in pond 5 before reaching a maximum of 
$565 \mu \mathrm{g} / \mathrm{L}$ in pond 6 . In contrast, the dissolved aluminum concentration in pond 1 was $15.8 \mu \mathrm{g} / \mathrm{L}$, then fluctuated between 5.5 and $10.1 \mu \mathrm{g} / \mathrm{L}$ in ponds 2 through 5 before reaching a maximum of $1,410 \mu \mathrm{g} / \mathrm{L}$ in pond 6 . Trace metals showed a more systematic variation with dissolved $\mathrm{Cd}$ going from less than detection $(<0.02 \mu \mathrm{g} / \mathrm{L})$ in the reference pond to $2.3 \mu \mathrm{g} / \mathrm{L}$ in pond 6 , dissolved $\mathrm{Cu}$ from $1.1 \mu \mathrm{g} / \mathrm{L}$ in the reference pond to to $1,380 \mu \mathrm{g} / \mathrm{L}$ in pond 6 , and dissolved $\mathrm{Zn}$ from $2.3 \mu \mathrm{g} / \mathrm{L}$ in the reference pond to $325 \mu \mathrm{g} / \mathrm{L}$ in pond 6 . For all three trace metals, the dissolved concentrations increased by a factor of 2 to 3 going from pond 5 to 6 . In April 2002, Holmes and others (2002) sampled tributary 2 downstream of the ponds prior to the confluence with Ely Brook (their site EB3) on two separate occasions. They found that $\mathrm{pH}$ ranged between 3.3 and 4.3 , hardness between 33 and $34 \mathrm{mg} / \mathrm{L} \mathrm{CaCO}$ equivalent, and dissolved sulfate between 66 and $74 \mathrm{mg} / \mathrm{L}$. Dissolved $\mathrm{Fe}$ concentrations ranged from 4,300 to 4,600 $\mu \mathrm{g} / \mathrm{L}$, dissolved $\mathrm{Al}$ from 2,500 to 3,600 $\mu \mathrm{g} / \mathrm{L}$, dissolved Cd from 1.9 to $2.4 \mu \mathrm{g} / \mathrm{L}$, dissolved $\mathrm{Cu}$ from 1,400 to 2,000 $\mu \mathrm{g} / \mathrm{L}$, and dissolved $\mathrm{Zn}$ from 260 to $310 \mu \mathrm{g} / \mathrm{L}$.

Prior to entering Schoolhouse Brook, Ely Brook (EB-90M) had low pH (3.2), high specific conductance $(447 \mu \mathrm{S} / \mathrm{cm})$, moderate hardness $\left(75.5 \mathrm{mg} / \mathrm{L} \mathrm{CaCO}_{3}\right)$, no alkalinity, and low DOC $(1.6 \mathrm{mg} / \mathrm{L})$. Dissolved Fe $(6,370 \mu \mathrm{g} / \mathrm{L})$, $\mathrm{Al}(4,190 \mu \mathrm{g} / \mathrm{L}), \mathrm{Cd}(2.0 \mu \mathrm{g} / \mathrm{L}), \mathrm{Cu}(1,560 \mu \mathrm{g} / \mathrm{L})$, and $\mathrm{Zn}$ $(373 \mu \mathrm{g} / \mathrm{L})$ concentrations were high.

Upon entering Schoolhouse Brook, the effluent from Ely Brook was diluted rapidly. Ely Brook only contributes approximately 7 percent of the flow to Schoolhouse Brook immediately downstream of their confluence on the basis of their drainage areas (table 2). Relative to sites EB-90M in Ely Brook and SB-3125M in Schoolhouse Brook downstream of the confluence in August 2006, dilution of Ely Brook resulted in an increase in $\mathrm{pH}$ from 3.2 to 7.8 , a decrease in specific conductance from 447 to $215 \mu \mathrm{S} / \mathrm{cm}$, and an increase in hardness from 75.5 to $95.9 \mathrm{mg} / \mathrm{L} \mathrm{CaCO}_{3}$. The DOC concentration was essentially unchanged $(1.6 \mathrm{mg} / \mathrm{L}$ at EB-90M and $1.3 \mathrm{mg} / \mathrm{L}$ at SB-3125M). Dissolved constituents that could be attributed to mine drainage from Ely Brook include sulfate, which decreased from 143 to $13 \mathrm{mg} / \mathrm{L}, 9$ percent of its orginal concentration; dissolved Fe, which dropped from 6,370 to $49 \mu \mathrm{g} / \mathrm{L}$, less than 1 percent of its original concentration; dissolved Al, which dropped from 4,790 to $109 \mu \mathrm{g} / \mathrm{L}$, 2.3 percent of its original concentration; $\mathrm{Cu}$, which dropped from 1,780 to $44 \mu \mathrm{g} / \mathrm{L}, 2.4$ percent of its original concentration; and $\mathrm{Zn}$, which dropped from 357 to less than $20 \mu \mathrm{g} / \mathrm{L}$, less than 6 percent of its original concentration. The drop in sulfate concentration was consistent with dilution considering its conservative behavior in solution; however, the magnitudes of decreases in $\mathrm{Al}, \mathrm{Fe}, \mathrm{Cu}$, and $\mathrm{Zn}$ indicated that the concentrations of these elements were additionally reduced by precipitation of $\mathrm{Fe}$ and $\mathrm{Al}$ hydroxides and sorption of $\mathrm{Cu}$ and $\mathrm{Zn}$ onto these substrates.

With increasing distance downstream in Schoolhouse Brook and then the Ompompanoosuc River, contamination from the site becomes increasingly diluted. Despite decreasing concentrations for mine-drainage constituents, the dissolved and total loads of most metals remained fairly constant from Ely Brook downstream to the Ompompanoosuc River (fig. 13). At OR-23200M, the water quality was virtually indistinguishable from background conditions with the exception of slightly elevated dissolved concentrations of aluminum $(44.6 \mu \mathrm{g} / \mathrm{L})$ and copper $(8.9 \mu \mathrm{g} / \mathrm{L})$. In addition to dilution, precipitation of $\mathrm{Fe}$ and $\mathrm{Al}$ hydroxides and sorption onto these substrates are also important controls on the concentrations of $\mathrm{Fe}, \mathrm{Al}$, and trace metals in solution.

With regards to chronic toxicity for aquatic ecosystems, only five elements exceeded water-quality standards locally: $\mathrm{Fe}, \mathrm{Al}, \mathrm{Cd}, \mathrm{Cu}$, and $\mathrm{Zn}$. Iron and $\mathrm{Al}$ have fixed standards, but those for $\mathrm{Cd}, \mathrm{Cu}$, and $\mathrm{Zn}$ are a function of water chemistry (USEPA, 2006, 2007). The hardness used to calculate the various water-quality standards was that of the sample rather than average values used for the whole site. Iron only exceeded chronic standards at 1 (EB-90M) of 18 sites, Al exceeded chronic standards at 5 of 18 sites, $\mathrm{Cd}$ and $\mathrm{Zn}$ both exceeded chronic standards at the same 5 of 18 sites, and $\mathrm{Cu}$ exceeded at 12 of 18 sites (fig. 22). Four of the six sites that did not exceed copper water-quality standards were reference sites upstream of mine-drainage contributions.

Problematic concentrations of dissolved iron are limited to EB-90M, which represented the sum of the Ely Brook watershed prior to emptying into Schoolhouse Brook. This site is more than $500 \mathrm{~m}$ downstream from its nearest site on Ely Brook. This site had the lowest $\mathrm{pH}$ and highest specific conductance of all sites included in this aquatic ecosystem assessment. The rapid natural attenuation of iron downstream of EB-90M reflected the combined influences of neutralization with attendant oxidation of ferrous iron and hydrolysis of ferric iron, and dilution.

The most problematic concentrations of dissolved aluminum were found in the lowermost pond (pond 6) and at EB-90M, which are the two sampled sites with the lowest $\mathrm{pH}$. In addition, Schoolhouse Brook downstream of Ely Brook had dissolved aluminium concentrations that ranged between 97 and 143 percent of its chronic value. Dilution by the Ompompanoosuc River dropped the value well below chronic levels. The high concentrations in the Ely Brook watershed clearly reflected the control of $\mathrm{pH}$ on aluminum solubility, and the necessity of low $\mathrm{pH}$ to attack silicate minerals and release aluminum to mine drainage. The natural attenuation of aluminum concentrations to levels just above the chronic water-quality standard was due to the neutralization of drainage from Ely Brook by Schoolhouse Brook and the associated precipitation of Al hydroxides. The persistence of these concentrations down to the confluence with the Ompompanoosuc River may have reflected colloidal aluminum that reported in the dissolved fraction.

The coincidence of high concentrations of cadmium and zinc was due to their identical source in the mine waste piles - the mineral sphalerite - and the similarity of their geochemical behaviors (Seal and Hammarstrom, 2003). Cadmium and zinc exceeded water-quality criteria in the two lowermost 
A

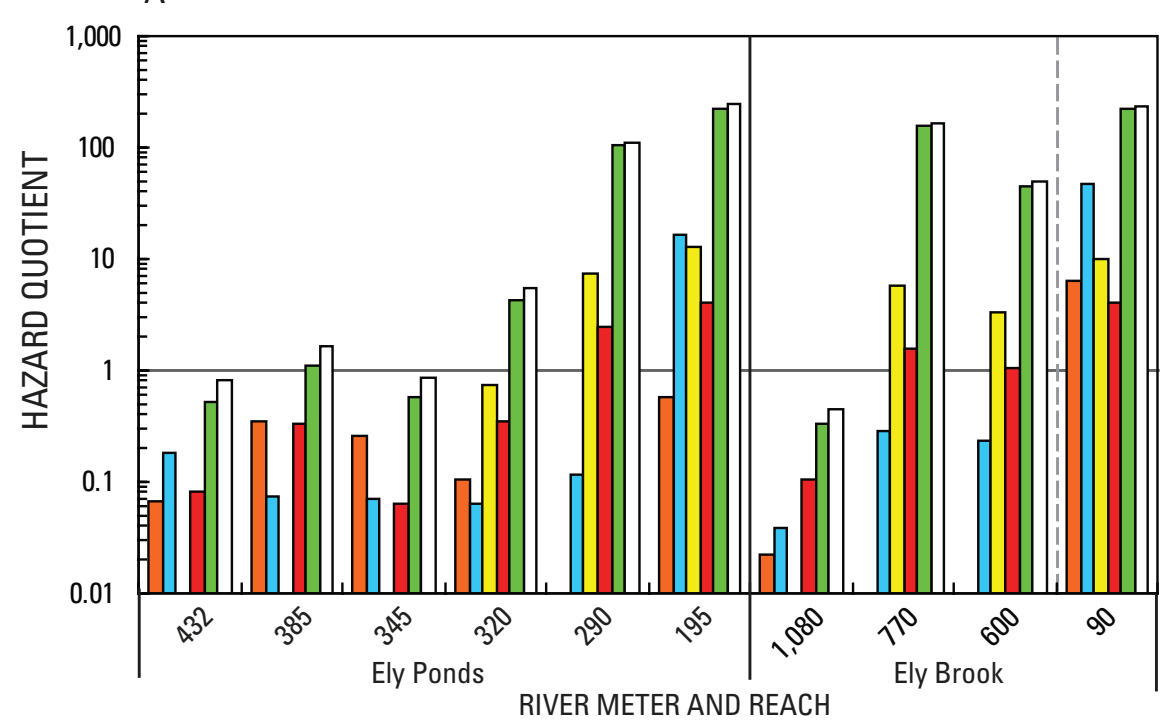

B

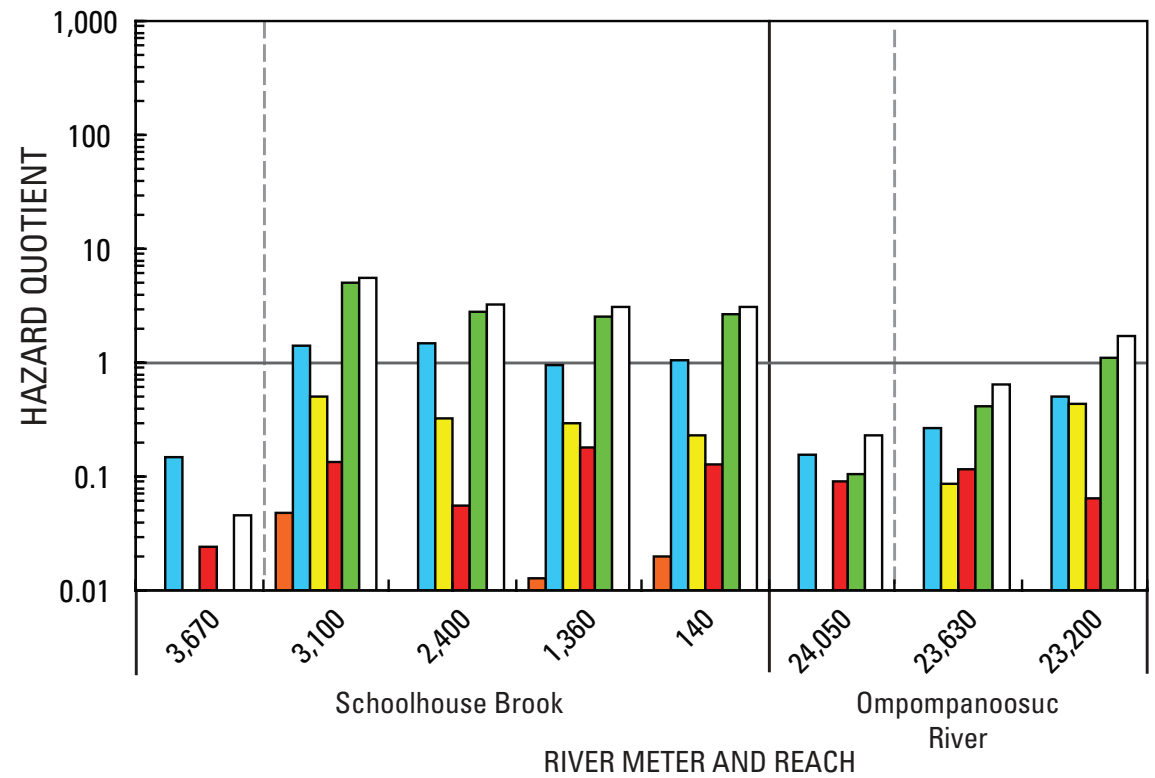

Explanation

$\square \mathrm{Fe}$

$\square \mathrm{Al}$

$\square \mathrm{Cd}$

$\square \mathrm{Zn}$

$\square \mathrm{Cu}$

$\square$ Sum of $\mathrm{Cd}, \mathrm{Cu}, \mathrm{Ni}, \mathrm{Pb}, \mathrm{Zn}$

Inflow of water from previous reach

Figure 22. Downstream variations in aluminum, iron, cadmium, copper, and zinc hazard quotients in surface waters at the Ely Mine Superfund site, Vershire, VT. $A$, Ely ponds and Ely Brook; B, Schoolhouse Brook and the Ompompanoosuc River. 
ponds, and throughout Ely Brook except for the reference site at the head waters (fig. 22). The fact that the HQ for cadmium relative to the chronic water-quality standards was far greater than that for zinc was a reflection of the low concentrations of the chronic standard for cadmium rather than its concentration in the watershed.

The concentrations of dissolved copper were most problematic and widespread of all of the contaminants in the vicinity of the site. In fact, comparison of HQs for copper relative to hardness-based chronic water-quality standards with the sum of HQs for $\mathrm{Cd}, \mathrm{Cu}, \mathrm{Ni}, \mathrm{Pb}$, and $\mathrm{Zn}$ clearly demonstrated that $\mathrm{Cu}$ was the dominant contaminant at all sample sites (fig. 22). Four of the six ponds exceeded chronic waterquality standards, as do all of Ely Brook and Schoolhouse Brook, except for the reference sites. Interestingly, the most downstream site on the Ompompanoosuc River (OR-23200M) marginally exceeded the chronic standards, whereas none of the sites closer to the source did.

Copper is the only element at present to have its USEPA (2006) hardness-based aquatic water-quality criteria superseded by aquatic criteria based on the Biotic Ligand Model
(Paquin and others, 2002; USEPA, 2007). Throughout most of the watershed, water-quality criteria calculated using both methods were similar, but significant differences were apparent in some of the Ely ponds and in Ely Brook as reflected by a comparison of HQs based on the two methods (fig. 23). For the ponds with the distinctly disparate HQs between the two methods (pond 5 and pond 6), the water chemistry had distinctly lower DOC concentrations and alkalinity, and higher concentrations of sulfate, $\mathrm{Cl}, \mathrm{K}$, and $\mathrm{Na}$, all of which were parameters used in the Biotic Ligand approach, but not the hardness-based approach. For Ely Brook, the disparate samples (EB-770M, EB-600M, EB-90M) were distinguished by their higher sulfate, $\mathrm{Cl}, \mathrm{Na}$, and $\mathrm{K}$ concentrations, as well as their low alkalinity. Both calcium and magnesium were higher in the lowermost Ely ponds, and in Ely Brook, but both approaches account for these differences. In the Ompompanoosuc River, the hardness-based HQs were higher than the Biotic Ligand Model quotients. This difference was likely due to the fact that the DOC concentrations in the Ompompanoosuc River were roughly twice those in Schoolhouse Brook.
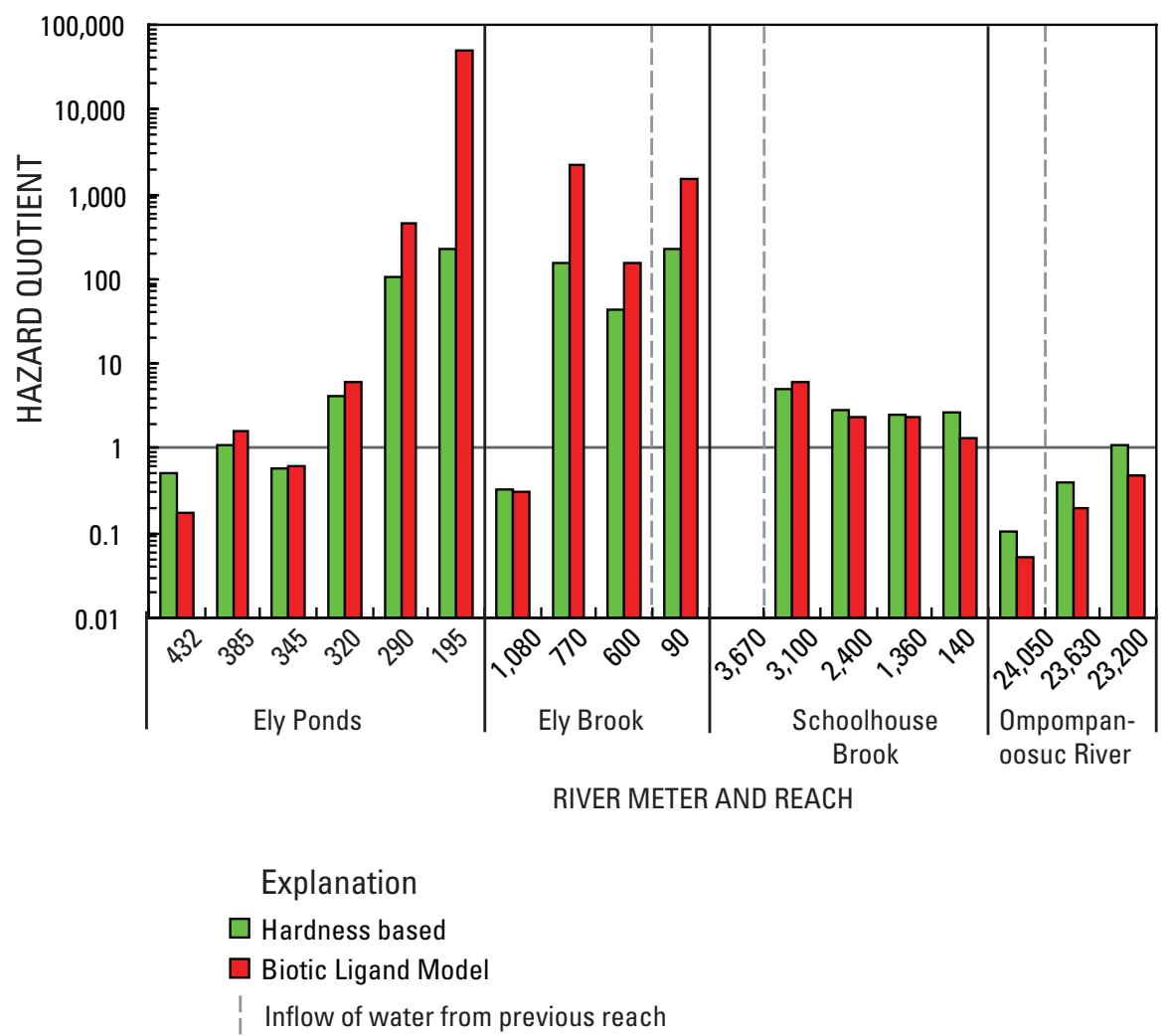

Figure 23. Downstream variations in hardness-based and Biotic Ligand Modelbased hazard quotients for copper in surface waters at the Ely Mine Superfund site, Vershire, VT. 


\section{Sediment and Pore-Water Toxicity}

Sediments from the 11 Ely Mine sites had similar physical and chemical characteristics (table 6 and appendix 4). All samples were dominated by sand-sized particles (67-94 percent) and had low levels of silt- and clay-sized particles (5-13 percent). All sediments had low levels of TOC and AVS, and these constituents were very consistent among locations. Sediments from Ely Brook, except the reference site EB-1080M, had high concentrations of iron ( $>5$ percent) and manganese ( $>1$ percent). Most pore waters had neutral to slightly alkaline $\mathrm{pH}$, except for slightly acidic $(\mathrm{pH}$ 6.1) pore waters from EB-770M and the highly acidic ( $\mathrm{pH} 3.0)$ pore water from EB-90M sediments. Site EB-90M pore waters also had very high concentrations of aluminum and iron, typical of waters affected by acid-mine drainage.

Sediment and pore waters from sites in Ely Brook, downstream of the mining area, had greater concentrations of metals than those from sites farther downstream from the mining area. Total copper concentrations in sediments from sites EB-770M, EB-600M, and EB-90M (table 6) exceeded PEC values, which are associated with greater risks of toxicity in sediment toxicity tests (MacDonald and others, 2000), by factors from 8 to 40 . All three sediment samples from Schoolhouse Brook downstream of the confluence of Ely Brook also exceeded the copper PEC. Sediments from sites in Ely Brook also had greatest concentrations of $\mathrm{Cr}, \mathrm{Cd}, \mathrm{Ni}$, $\mathrm{Zn}$, and $\mathrm{Pb}$, although none of these metals exceeded PECs except $\mathrm{Pb}$ concentrations in the EB-600M sediment. Total metal concentrations did not show a pattern of consistent decrease downstream from Ely Brook, although concentrations of several metals were substantially lower in sediments from OR-23200M compared to upstream sites. Metals in SEM extracts followed patterns similar to those of total metals, except that greatest concentrations of $\mathrm{SEM} \mathrm{Cu}, \mathrm{Cd}, \mathrm{Ni}$, and $\mathrm{Zn}$ occurred in sediments from EB-600M rather than EB-90M. Only about 1 percent of the total copper in EB-90M sediments was in labile forms, compared to one-third of the total copper in EB-600M sediments. Metal concentrations in pore waters followed trends more similar to total metal concentrations. Pore waters of sediments from Ely Brook, particularly those from EB-90M, also had greatest concentrations of $\mathrm{Cd}, \mathrm{Cu}$, $\mathrm{Ni}, \mathrm{Pb}$, and $\mathrm{Zn}$. Concentrations of $\mathrm{Cu}$ and $\mathrm{Cd}$ in pore waters from all three Ely Brook sediment sites downstream from the reference site exceeded hardness-adjusted chronic water quality criteria (table 11; USEPA, 2006) for all three pore-water sample types - in situ, centrifuged, and 28-day equilibration samples. Zinc concentrations in pore waters locally exceeded hardness-adjusted chronic criteria in various sample types at EB-600M and EB-90M. Downstream in Schoolhouse Brook, hardness-adjusted chronic water-quality criteria for copper were exceeded at all sites for at least one pore-water sample type, but no exceedances were found for $\mathrm{Cd}$ or $\mathrm{Zn}$ in any sample. In the Ompompanoosuc River, copper exceeded the hardness-adjusted chronic water-quality criteria only for the 28-day equilibrated pore-water sample at OR-23200M.

Indices of toxicity risk based on total sediment metals, metals in the SEM fraction, and pore-water metals indicated a wide range of toxicity risks among the eleven study sites (fig. 24). An index based on the probable effects quotient (PEQ) for total sediment metals ( $\Sigma \mathrm{PEQ}=$ sum of [total metal concentration/PEC]) indicated greatest toxicity risk for sediments from Ely Brook, with $\Sigma$ PEQ values ranging from 10 (EB-770M) to 42 (EB-90M).

Ingersoll and others (2001) documented greater than 50 percent frequency of toxicity in tests with H. azteca and C. tentans in metals-contaminated sediments with mean PEQ values of 1.0 or greater - values equivalent to $\Sigma \mathrm{PEQ}$ of 6 or greater in this study. The $\Sigma$ PEQ index indicated lower toxicity risks for sediments from downstream sites ( $\Sigma$ PEQ from 1.3 to 2.8 ) and reference sites ( $\Sigma$ PEQ from 0.7 to 1.7$)$. An index based on pore-water toxic units $(\Sigma T \mathrm{TU}=$ sum of [pore-water metal/chronic water-quality criterion]) followed a similar pattern. For each reach, the $\Sigma T U$ value for each reference site was lower than those on the same reach and downstream of inputs of mine-influenced water and sediment. In the mineralized Ely Brook watershed, the $\Sigma T U$ value at the reference site (EB-1080M) was greater than 1, whereas at the reference sites in Schoolhouse Brook (SB-360M) and the Ompompanoosuc River (OR-24050M), the values were less than 1 . The pore-water toxicity units for Ely Brook steadily increase downstream, reaching a maximum of 270 at site EB-90M (fig. 25). The pore-water $\Sigma T U$ values drop dramatically upon entering Schoolhouse Brook and fluctuate slightly above or below 1 throughout Schoolhouse Brook and downstream to the lowermost sampling site on the Ompompanoosuc River (OR-23200M) (fig. 25).

The ESB index proposed by USEPA (2005), which adjusts SEM concentrations to approximate binding of metals by AVS and organic carbon $\left(\mathrm{ESB}\right.$ index $=\Sigma \mathrm{SEM}-\mathrm{AVS} / \mathrm{f}_{\mathrm{OC}}$ ), suggested a slightly different pattern of toxicity risks, with greatest risks for EB-770M and EB-600M sediments, lower risks for sediments from EB-90M and Schoolhouse Brook, and no risk of metal toxicity (that is, negative index values) for sediments from OR-23200M and all reference sites. ESB indices for sediment from EB-600M exceeded the USEPA (2005) benchmark for probable toxicity $(3,000 \mu \mathrm{mol} / \mathrm{gOC})$. Other sediments collected from the mining-affected reach of Ely and Schoolhouse Brooks fell into the range of uncertain toxicity $(130-3,000 \mu \mathrm{mol} / \mathrm{gOC})$. 
Table 11. Summary of the concentration, hazard quotient, and hazard index for select constituents in pore waters at sampling locations in the Ely Mine study area, Vershire, VT, August and September 2006. Refer to table 1 and figure 1 for site names, station numbers, and locations.

[in situ, in situ pore water; centri., centrifuge pore water; equil., equilibrated pore water; $\mu \mathrm{g} / \mathrm{L}$, micrograms per liter; mg/L, milligrams per liter; <, analyte not detected at the reporting level; ins, insufficent sample; - , not determined]

\begin{tabular}{|c|c|c|c|c|c|c|c|c|c|c|c|c|c|c|c|c|c|c|}
\hline \multirow{3}{*}{$\begin{array}{l}\text { Stream and } \\
\text { location }\end{array}$} & \multicolumn{15}{|c|}{ Concentration ( $\mu \mathrm{g} / \mathrm{L}$ ) } & \multirow{2}{*}{\multicolumn{3}{|c|}{$\begin{array}{c}\text { Concentration } \\
\left(\mathrm{mg} / \mathrm{LaCO}_{3}\right)\end{array}$}} \\
\hline & \multicolumn{3}{|c|}{ Cadmium } & \multicolumn{3}{|c|}{ Copper } & \multicolumn{3}{|c|}{ Nickel } & \multicolumn{3}{|c|}{ Lead } & \multicolumn{3}{|c|}{ Zinc } & & & \\
\hline & in situ & centri. & equil. & in situ & centri. & equil. & in situ & centri. & equil. & in situ & centri. & equil. & in situ & centri. & equil. & in situ & centri. & equil. \\
\hline \multicolumn{19}{|l|}{ Ely Brook } \\
\hline EB-1080M & $<0.02$ & 1.66 & 0.11 & 2.4 & 10.2 & 4.3 & 0.6 & 1.4 & 1.7 & 0.06 & 0.91 & $<0.05$ & 1.5 & 29.2 & 1.6 & 36 & 80 & 200 \\
\hline EB-770M & 0.28 & 1.25 & 1.95 & 27.4 & 43.4 & 106 & 4.3 & 12.6 & 20 & 0.2 & $<0.05$ & $<0.05$ & 25.1 & 50 & 114 & 46 & 102 & 178 \\
\hline EB-600M & 0.3 & 0.34 & 0.59 & 42.7 & 108 & 59.6 & 4 & 3.9 & 4.5 & $<0.05$ & 0.08 & $<0.05$ & 31.6 & 24.8 & 26 & 45 & 52 & 67 \\
\hline EB-90M & 1.85 & 2.87 & 2.62 & 1,800 & 2,140 & 1,700 & 17.4 & 31.1 & 39 & 1.9 & 1.2 & 1.7 & 314 & 514 & 616 & 73 & 108 & 103 \\
\hline \multicolumn{19}{|c|}{ Schoolhouse Brook } \\
\hline SB-3670M & $<0.02$ & 0.04 & 0.04 & $<0.5$ & 1 & 2.9 & $<0.4$ & 2.4 & 4.1 & 0.06 & 0.1 & 0.1 & 1.9 & 3.8 & 4.4 & 111 & 172 & 278 \\
\hline SB-2400M & 0.08 & 0.15 & 0.3 & 7.9 & 16.8 & 322.8 & 0.5 & 2.9 & 2.6 & $<0.05$ & 0.1 & 0.05 & 3 & 6.4 & 4.9 & 130 & 197 & 252 \\
\hline SB-1360M & 0.05 & 0.17 & 0.27 & 9.6 & 18.1 & 24.9 & 0.8 & 2.2 & 2.2 & 0.2 & 0.09 & $<0.05$ & 149 & 6 & 7 & 94 & 143 & 257 \\
\hline SB-140M & 0.04 & 0.22 & 0.4 & 5.6 & 8.5 & 521.6 & 0.6 & 2.6 & 2.2 & 0.2 & 0.1 & 0.1 & 8 & 5.3 & 7.4 & 108 & 178 & 276 \\
\hline \multicolumn{19}{|c|}{ Ompompanoosuc River } \\
\hline OR-24050M & $<0.02$ & ins & 0.04 & 0.56 & ins & 1.6 & 0.4 & ins & 3.8 & $<0.05$ & ins & 0.09 & 3.8 & ins & 2.4 & 141 & 188 & 374 \\
\hline \multirow[t]{2}{*}{ OR-23200M } & 0.06 & 0.19 & 0.09 & 4.5 & 14.2 & 19.1 & 0.8 & 2.8 & 2.2 & 0.3 & 0.09 & 0.2 & 2.9 & 3.4 & 5.7 & 96 & 187 & 234 \\
\hline & \multicolumn{15}{|c|}{ Hazard quotient } & \multicolumn{3}{|c|}{ Hazard index } \\
\hline \multicolumn{19}{|l|}{ Ely Brook } \\
\hline EB-1080M & - & 7.9 & 0.3 & 0.6 & 1.4 & 0.3 & 0.0 & 0.0 & 0.0 & 0.1 & 0.5 & - & 0.6 & 0.0 & 0.1 & 1.3 & 9.7 & 0.7 \\
\hline EB-770M & 2.0 & 5.0 & 5.3 & 6.0 & 4.8 & 7.2 & 0.2 & 0.2 & 0.2 & 0.2 & - & - & 0.8 & 0.9 & 0.2 & 9.2 & 11.0 & 12.9 \\
\hline EB-600M & 2.1 & 2.2 & 3.2 & 9.4 & 20.9 & 9.4 & 0.2 & 0.1 & 0.1 & - & 0.1 & - & 0.4 & 0.4 & 3.7 & 12.0 & 23.7 & 16.4 \\
\hline EB-90M & 9.3 & 11.1 & 10.4 & 262.2 & 223.9 & 185.2 & 0.4 & 0.6 & 0.7 & 1.1 & 0.4 & 0.7 & 5.7 & 4.9 & 0.0 & 278.7 & 240.8 & 197.0 \\
\hline \multicolumn{19}{|c|}{ Schoolhouse Brook } \\
\hline SB-3670M & - & 0.1 & 0.1 & - & 0.1 & 0.1 & - & 0.0 & 0.0 & 0.0 & 0.0 & 0.0 & 0.0 & 0.0 & 0.0 & 0.0 & 0.3 & 0.3 \\
\hline SB-2400M & 0.3 & 0.4 & 0.6 & 0.7 & 1.0 & 1.2 & 0.0 & 0.0 & 0.0 & - & 0.0 & 0.0 & 0.0 & 0.0 & 0.6 & 1.0 & 1.5 & 2.4 \\
\hline SB-1360M & 0.2 & 0.5 & 0.6 & 1.1 & 1.5 & 1.2 & 0.0 & 0.0 & 0.0 & 0.1 & 0.0 & - & 0.1 & 0.0 & 0.0 & 1.5 & 2.1 & 1.9 \\
\hline SB-140M & 0.2 & 0.6 & 0.8 & 0.6 & 0.6 & 1.0 & 0.0 & 0.0 & 0.0 & 0.1 & 0.0 & 0.0 & 0.0 & 0.0 & 0.0 & 0.9 & 1.3 & 1.9 \\
\hline \multicolumn{19}{|c|}{ Ompompanoosuc River } \\
\hline OR-24050M & - & - & 0.1 & 0.0 & - & 0.1 & 0.0 & - & 0.0 & - & - & 0.0 & - & 0.0 & 0.0 & 0.0 & 0.0 & 0.2 \\
\hline OR-23200M & 0.3 & 0.5 & 0.2 & 0.5 & 0.9 & 1.0 & 0.0 & 0.0 & 0.0 & 0.1 & 0.0 & 0.0 & 0.0 & 0.0 & 0.0 & 0.9 & 1.5 & 1.3 \\
\hline
\end{tabular}




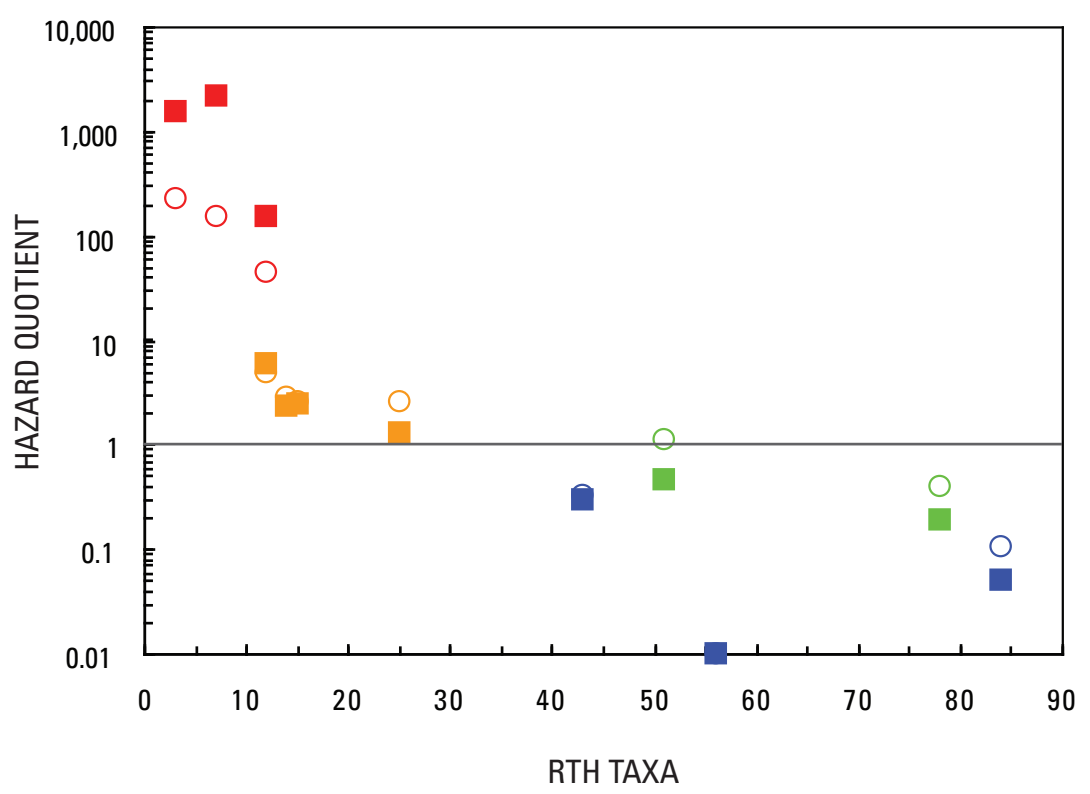

Explanation

- HB reference

- HB Ely Brook

$\circ$ HB Schoolhouse Brook

- HB Ompompanoosuc River

- BLM reference

- BLM Ely Brook

- BLM Schoolhouse Brook

- BLM Ompompanoosuc River

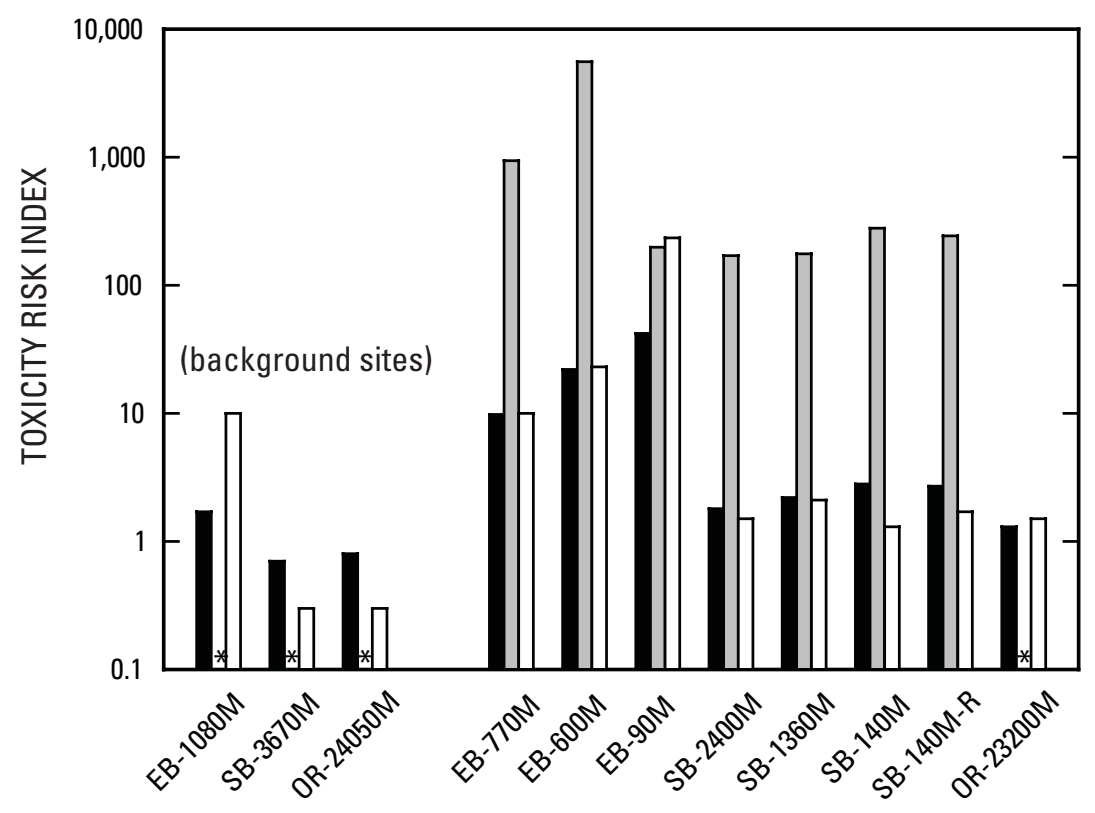

Explanation

PEC quotients

ESB index ( $\mu \mathrm{mol} / \mathrm{gOC})$

Pore-water toxic units
Figure 24. Chronic copper water-quality criteria for surface water based on hardness (HB) (U.S. Environmental Protection Agency, 2006) and the Biotic Ligand Model (BLM) (USEPA, 2007) with the number of riffle-targeted habitat (RTH) taxa.
Figure 25. Three indices of metal toxicity risks for instream sediments from the Ely Mine site, August 2006. The probable effects concentration (PEC) quotients are sums of total sediment metal concentration divided by probable effect concentration (MacDonald and others, 2000). The equilibrium-partitioning sediment benchmark (ESB) index is the difference between the sum of the concentration of simultaneously extractable metals and the acid volatile sulfide concentration, both expressed as micromoles per kilogram of sediment, divided by the fraction of total organic carbon (OC) on a mass basis [ $\left.\Sigma S E M-A V S / f_{0 C}\right]$ (USEPA, 2005). Toxic units are sums of pore-water metal concentration divided by water-quality criterion (U.S. Environmental Protection Agency, 2004). Asterisks indicate values less than zero. Sample SB-140M- $R$ is a lab replicate of SB-140M. 


\section{Bioassay Results}

Survival and growth of $H$. azteca provided clear evidence for toxicity of sediments collected downstream of the mining area (table 8). Both survival and growth of amphipods differed significantly among sediments in the overall ANOVA and in the separate ANOVAs for Ely Brook and Schoolhouse Brook but not Ompompanoosuc River. Amphipod survival was high (96 percent) in the control sediment, and the arithmetic means for survival and growth were consistent among the control and the three reference sediments. Both amphipod endpoints followed similar patterns among sites, with significant toxic effects (significant reductions relative to reference sediments) occurring in six of seven sites in the reach of Ely Brook and Schoolhouse Brook, from EB-770M downstream to SB-140M. Greatest effects on both survival and growth occurred in EB$600 \mathrm{M}$ sediments, with survival reduced by about 80 percent and growth reduced by about 40 percent, relative to reference sites. There was no evidence of toxicity to amphipods in sediments from EB-90M or in sediments from the most downstream site, OR-23200M.

Results of the midge toxicity tests indicated significant toxic effects of sediments downstream of the Ely Mine site on midge growth but not on survival (table 8). Midge survival in the control sediment ( 86 percent) was above the minimum for test acceptability (70 percent; ASTM, 2007), but survival varied widely (64-90 percent) among the three reference sediments. Survival differed significantly among sediments in the overall ANOVA, but there were no significant reductions relative to reference sediments. There was a general trend for increasing midge survival with distance downstream, with differences among sites in each stream (including reference sites) being less than differences among the three streams. Growth of midge larvae also differed significantly among sediments in the overall ANOVA, and differences among treatments followed trends similar to those observed for amphipod survival and growth. Midge growth in reference sediments from all three study streams fell within a narrow range (1.00-1.21 mg AFDW), but sediments from most sites in Ely and Schoolhouse Brooks caused significantly lower growth than reference sediments in these streams. As was observed in the amphipod test, greatest reductions in midge growth occurred in sediments from EB-600M, and there were no significant effects on growth in the EB-90M and OR-23200M sediments. Of the six sediments that caused significant reductions in amphipod endpoints, only SB-1360M did not cause significant reductions in midge growth, relative to the reference sediment.

The increased survival for both species associated with sediment from site EB-90M, despite its being the most being the most toxic with respect to surface and pore water, is intriguing. The low $\mathrm{pH}$ of the surface and pore water would act to strip labile metals from the sediments, making whatever metal remains more refractory and less bioavailable. The SEM-AVS results for site EB-90M support this hypothesis. The copper concentration and $\mathrm{Cu} / \mathrm{Fe}$ ratio of the sediments at EB-90M are among the highest in the study area, but the simultaneously extractable copper is the lowest in the study area (fig. 26). Alternatively, the pre-test flushing of the sediment with moderately hard test water $\left(100 \mathrm{mg} / \mathrm{L} \mathrm{CaCO}_{3}\right)$ with moderate alkalinity may have artificially resulted in the precipitation of hydrated ferric oxides, which may have sequestered trace metals, rendering them unavailable.
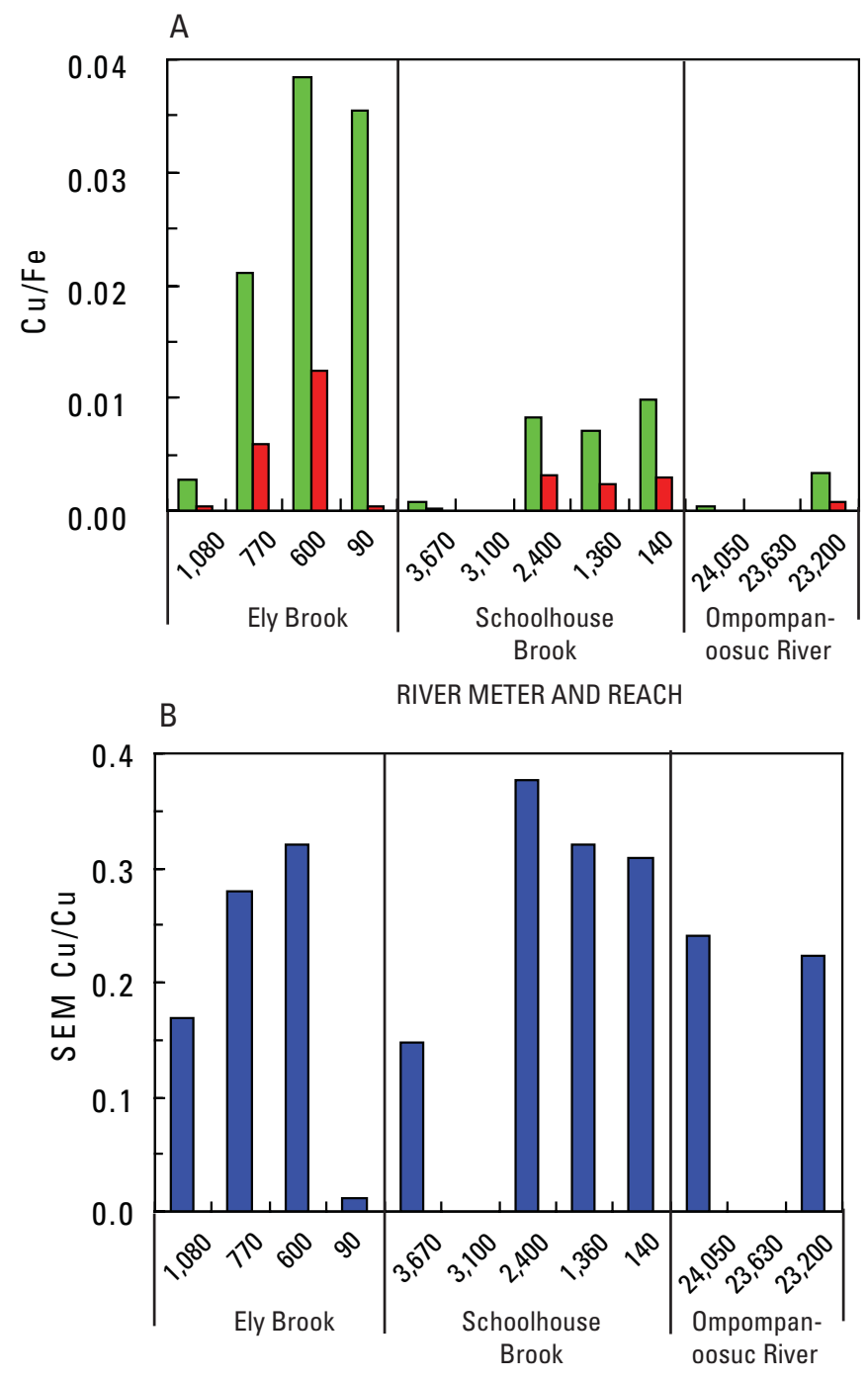

RIVER METER AND REACH

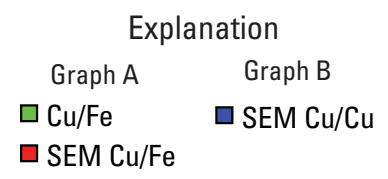

Figure 26. Copper ( $\mathrm{Cu}$ ) and iron (Fe) concentrations in stream sediments. Sites with no bars represent sites without samples. $A$, The variation within the watershed of the mass ratio of total $\mathrm{Cu}$ to total $\mathrm{Fe}$, and the mass ratio of labile (SEM) Cu to total Fe. $B$, The variation within the watershed of the ratio labile (SEM) Cu to total $\mathrm{Cu}$. 


\section{Ecological Indicators}

The results of this study strongly indicated that the waterways that were investigated were impaired by acid-mine drainage from the Ely Mine site. Values of invertebrate abundance and richness were highest at reference sites, which were located above acid-rock drainage inflow for all waterways: Ely Brook, Ely ponds, Schoolhouse Brook, and Ompompanoosuc River. Fish IBI scores followed the same trend except in the Ompompanoosuc River, where the scores were as high as the reference-site IBI score. The extent of impairment to invertebrates and fish also appeared to be related to the HI values derived from the surface-water and pore-water samples.

Surface-water HI values were less than 1.0 at all reference sites for all streams, and an increase in the HI values corresponded to an increase in impairment (lower abundance and richness in RTH samples). The Ompompanoosuc River site downstream from the confluence of Schoolhouse Brook (OR23630) was one of only two non-reference sites for a stream that had a surface-water HI value below 1.0; RTH taxa richness was only slightly lower than the reference (OR-24050), and the site was not categorized as impaired by VTDEC. The QMH invertebrate data from the ponds also indicated that impairment was related to the surface-water HIs. Although the $\mathrm{HI}$ at pond 2 was 1.6 , impairment was relatively minor compared to pond 4, which had substantially lower invertebrate abundance and richness values, and the HI was 5.6.

Pore-water HIs were also less than 1.0 at all reference sites except for the in situ and centrifuged samples at EB1080M. Impairment to the RTH invertebrate assemblages in Ely Brook strongly corresponded to a very large increase in the HIs downstream of the reference (HI from 1.3 to 279). However, severe impairment to the DTH invertebrate assemblages also occurred in Schoolhouse Brook downstream from the confluence with Ely Brook, although the pore-water HI was only 1 at the first site downstream from the confluence of Ely Brook that was sampled for DTH invertebrate assemblages (SB-2400M), although this was not the site immediately below the confluence (SB-3100M). This stream was characterized as high gradient, and there were only a few depositional areas from which to collect samples. These areas were typically small and the depositional material most likely transient in its placement. Therefore, the DTH invertebrate assemblages are probably affected by surface-water flows and contamination as well as pore-water contamination. Such interactions are also likely throughout the water bodies affected by acid-rock drainage, where a certain amount of residual toxicity in the sediments affects invertebrate assemblages, but toxicity would increase during storm events as contaminant concentrations increase in the overlying surface waters. Furthermore, this interaction would be most pronounced nearer the source of contamination because contaminants in surface water would be diluted farther downstream as additional water is added from the increasing area of the drainage basin.
To determine the extent of impairment to streams affected by Ely Mine, the VTDEC has made biological assessments to Ely Brook and Schoolhouse Brook for two decades and to the Ompompanoosuc River since 2001 (VTDEC, 2008). These assessments have been based on the fish and macroinvertebrate assemblages (for example, RTH) similar to the surveys conducted for this report, and the results are directly comparable (table 9). Ely Brook was first assessed as “poor" in 1987, based on the invertebrate assemblage surveyed that year at a site that corresponds to EB-90M from this study. Using the RTH invertebrate data from this study, VTDEC assessed the four Ely Brook sites below the acid-rock drainage inflow as "poor" and the site above the acid-rock drainage inflow as "very good to good." The VTDEC also made determinations of whether stream segments were supporting of aquatic life for Class B waters in Vermont, and only the segment above acid-rock drainage inflow was supporting for Ely Brook.

Surveys of fish, invertebrates, or both have occurred at sites along Schoolhouse Brook in 1987, 1988, 1997, 2000, 2001, and for this study in 2006 (table 12). Assessments based on fish assemblages have ranged from "good" to "excellent" at sites above acid-rock drainage inflow (that is, Ely Brook confluence), and "poor" for sites below acid-rock drainage inflow except for a "fair" assessment for the most downstream site for 2006, based on the fish survey from this study. Invertebrate assemblages in Schoolhouse Brook were assessed as "good" to "excellent" at two sites above acid-rock drainage inflow, and consistently "poor" at sites below acid-rock drainage inflow. The aquatic-life use determination by VTDEC was that the segment of Schoolhouse Brook above acid-rock drainage inflow was supporting for Class B waters but that the entire section below acid-rock drainage was non-supporting.

Surveys of fish in the Ompompanoosuc River were conducted in 2001, 2002, 2006, and 2007, and invertebrate assemblages were surveyed in 2005 and 2006 (table 12). Data from the 2006 and 2007 surveys were collected for this study. Assessments based on fish assemblages were either "good" or "very good" upstream of acid-rock drainage inflow (that is, Schoolhouse Brook confluence) but were either "poor" or "good" below the acid-rock drainage inflow. Only in this segment of the Ompompanoosuc River (below the confluence with Schoolhouse Brook) was there any variation in the assessment over time, which may have been caused by acid-rock drainage or by other factors. From the data collected for this study, the difference in the 2006 and 2007 "poor" and "good" assessments, respectively, was based on fewer fish collected and not a difference in assemblage structure. Lower abundance could be a result of contamination but also a result of less habitat structure or low capturing efficiency during the sampling effort. In 2002, the VTDEC made an assessment of "poor" based on a fish survey at a site about $3 \mathrm{~km}$ below the Schoolhouse Brook confluence. However, the VTDEC had conducted a fish survey at a site about $6 \mathrm{~km}$ farther downstream; this site was assessed as "good" and had an IBI score (35) that exceeded the Ompompanoosuc reference site score (33). 
Table 12. Summary of the aquatic-life use (ALU) assessments for streams associated with the Ely Mine site.

[The assessments were derived by the State of Vermont (VTDEC) with data from this study (dates in red font) and from previous studies (VTDEC, 2008). Note that VTDEC uses river mile to designate site locations. The designation "ARD inflow" indicates the relative location along the stream where acid-rock drainage affects water quality. For the fish index of biotic integrity (IBI) scores, MW or CW next to the value indicates a mixed water or cold water index, respectively, was used for the assessment. The ALU determination (last column) indicates whether or not the stream is supporting of Class B waters in Vermont, based on the assessments of fish and invertebrate assemblages]

\begin{tabular}{|c|c|c|c|c|c|c|c|c|c|}
\hline $\begin{array}{l}\text { VTDEC } \\
\text { site } \\
\text { (river } \\
\text { mile) }\end{array}$ & $\begin{array}{l}\text { USGS site } \\
\text { designation }\end{array}$ & $\begin{array}{c}\text { Fish survey } \\
\text { date }\end{array}$ & $\begin{array}{c}\text { Fish } \\
\text { assess- } \\
\text { ment }\end{array}$ & $\begin{array}{l}\text { Fish IBI } \\
\text { score }\end{array}$ & $\begin{array}{c}\text { Invertebrate } \\
\text { survey date }\end{array}$ & $\begin{array}{l}\text { Invertebrate } \\
\text { assessment }\end{array}$ & $\begin{array}{c}\text { Inverte- } \\
\text { brate } \\
\text { density }^{a}\end{array}$ & $\begin{array}{c}\text { Inverte- } \\
\text { brate } \\
\text { richness }^{\mathrm{a}}\end{array}$ & $\begin{array}{c}\text { ALU } \\
\text { determination }\end{array}$ \\
\hline \multicolumn{10}{|c|}{ Ely Brook (Schoolhouse Brook Tributary 3)—small high-gradient stream (SHG) } \\
\hline 0.9 & EB-1080M & & & & 09-06-2006 & Very good/Good & 1,744 & 40 & Supporting \\
\hline \multicolumn{10}{|c|}{$\rightarrow$ ARD inflow } \\
\hline 0.7 & EB-770M & & & & 09-06-2006 & Poor & 8 & 7 & Non-supporting \\
\hline 0.4 & EB-600M & & & & 09-06-2006 & Poor & 37 & 11 & Non-supporting \\
\hline \multirow{2}{*}{0.1} & \multirow{2}{*}{ EB-90M } & & & & 09-06-2006 & Poor & 38 & 3 & \multirow{2}{*}{ Non-supporting } \\
\hline & & & & & 09-30-1987 & Poor & 1 & 1 & \\
\hline \multicolumn{10}{|c|}{ Schoolhouse Brook-small high-gradient stream (SHG) } \\
\hline \multirow[t]{2}{*}{2.4} & SB-3670M & 09-13-2006 & Excellent & $42 \mathrm{CW}$ & 09-06-1006 & Good & 3,440 & 48 & Supporting \\
\hline & & 09-19-2000 & Excellent & $45 \mathrm{CW}$ & $10-25-2001$ & Excellent & 1,175 & 44 & Supporting \\
\hline \multirow[t]{2}{*}{2.3} & & 09-10-1997 & Very Good & $39 \mathrm{CW}$ & 09-10-1997 & Excellent & 574 & 45 & \\
\hline & & 07-08-1988 & Good & $33 \mathrm{CW}$ & 09-30-1987 & Excellent & 224 & 42 & \\
\hline \multicolumn{10}{|c|}{$\rightarrow A R D$ inflow } \\
\hline \multirow[t]{4}{*}{2.2} & SB-3100M & $09-13-2006$ & Poor & $9 \mathrm{CW}$ & 09-06-2006 & Poor & 25 & 12 & Non-supporting \\
\hline & & 09-19-2000 & Poor & $9 \mathrm{CW}$ & $10-25-2001$ & Poor & 14 & 8 & \\
\hline & & 09-10-1997 & Poor & $9 \mathrm{CW}$ & 09-10-1997 & Poor & 29 & 13 & \\
\hline & & 07-07-1988 & Poor & $9 \mathrm{CW}$ & 09-30-1987 & Poor & 8 & 6 & \\
\hline 1.7 & SB-2400M & 09-13-2006 & Poor & $9 \mathrm{CW}$ & 09-06-2006 & Poor & 96 & 12 & Non-supporting \\
\hline 1.0 & SB-1360M & 09-13-2006 & Poor & $18 \mathrm{CW}$ & 09-06-2006 & Poor & 73 & 13 & Non-supporting \\
\hline \multirow[t]{2}{*}{0.4} & & $10-25-2001$ & Poor & $9 \mathrm{MW}$ & $10-25-2001$ & Poor & 82 & 18 & Non-supporting \\
\hline & & & & & 09-30-1987 & Poor & 3 & 3 & Non-supporting \\
\hline 0.2 & SB-140M & 09-13-2006 & Fair & $29 \mathrm{MW}$ & 09-06-2006 & Poor & 274 & 17 & Non-supporting \\
\hline \multicolumn{10}{|c|}{ Ompompanoosuc River-medium-gradient stream (MHG) } \\
\hline \multirow[t]{2}{*}{16.1} & OR-24050M & $10-25-2001$ & Very Good & $37 \mathrm{MW}$ & & & & & Supporting \\
\hline & & 09-12-2006 & Good & $33 \mathrm{MW}$ & 09/06/2006 & Excellent/Very good & 2,862 & 69 & \\
\hline \multicolumn{10}{|c|}{$\rightarrow A R D$ inflow } \\
\hline 15.9 & OR-23630M & 09-12-2006 & Good & $33 \mathrm{MW}$ & 09/06/2006 & Good & 3,114 & 63 & Supporting \\
\hline \multirow[t]{2}{*}{15.6} & OR-23200M & 09-12-2006 & Poor & $9 \mathrm{MW}$ & 09/06/2006 & Good & 1,920 & 48 & Supporting \\
\hline & & 09-11-2007 & Good & $33 \mathrm{MW}$ & & & & & \\
\hline 13.8 & & 07-11-2002 & Poor & $9 \mathrm{MW}$ & & & & & \\
\hline 10.1 & & 09-11-2001 & Good & $35 \mathrm{MW}$ & & & & & Supporting \\
\hline 7.3 & & & & & 09-26-2005 & Very good & 1,325 & 46 & Supporting \\
\hline
\end{tabular}

${ }^{a}$ Invertebrate density and richness values that are based on data from this study (dates shown in red font) are shown here as lower than abundance and richness values in table 9 in some cases. This difference occurs because VTDEC does not include all taxa in deriving metrics used for biological assessments.

The invertebrate assemblages at the Ompompanoosuc River reference site were surveyed only once (data from this study) but were assessed as "excellent" to "very good." Downstream from the acid-rock drainage inflow, the assessments were slightly downgraded to "good," based on the 2006 data for this study, but "very good" for a 2005 invertebrate survey at a site about $13.5 \mathrm{~km}$ downstream from Schoolhouse Brook. Comprehensively, the results from the fish and invertebrate surveys on the Ompompanoosuc River indicate that there may be some degree of impairment to the river from acid-rock drainage.
The indication of a slight increase in the impairment at site OR23200M, even compared to site OR-23630 (immediately below Schoolhouse Brook), was supported by the HI values for surface water; of the three Ompompanoosuc River sites in this study, the HI exceeded 1.0 only at site OR-23200M. However, if acid-rock drainage is responsible for any degree of impairment to biological assemblages in the Ompompanoosuc River, they were relatively minor; the determination by VTDEC was that the segments upstream and downstream from the acid-rock drainage inflow were all supporting of Class B waters (table 12). 


\section{Comparison of Aquatic Ecosystem Health Indicators}

The geochemical data for surface waters and sediments, along with toxicity testing data, and ecological data all provide a reasonably consistent assessment of downstream aquatic ecosystem impairment related to the Ely Mine and are summarized in table 13 for the stream habitat and table 14 for the pond habitat. The results provide strong evidence that acidity and metals from the Ely Mine site have contaminated surface waters and sediments in Ely and Schoolhouse Brooks, leading to toxic effects on fish and benthic invertebrates. Analyses of metal concentration in surface waters, sediment, and pore water indicated that toxicity risks downstream of the Ely Mine site were driven primarily by high copper concentrations in all media, although other metals ( $\mathrm{Al}, \mathrm{Cd}, \mathrm{Cr}, \mathrm{Fe}, \mathrm{Ni}, \mathrm{Pb}$, and $\mathrm{Zn}$ ) may have contributed locally to toxicity.

In terms of surface water, there are essentially no differences in the reaches exceeding acute and chronic waterquality criteria with the exception of site OR-23200M, which exceeds the chronic but not acute criterion. Surface-water toxicity tests showed identical impairment throughout Ely Brook and Schoolhouse Brook. Riffle-habitat invertebrates downstream of reference sites in Ely Brook and Schoolhouse Brook showed significant decreases in both the number of taxa and the number of individuals. Riffle-habitat invertebrates in the Ompompanoosuc River showed no significant differences above or below the confluence with Schoolhouse Brook. For the fish community, similar results were found. The IBI showed significant impairment in Schoolhouse Brook downstream of Ely Brook, but no variation was observed in the Ompompanoosuc River.

Locally significant differences in the level of predicted copper toxicity are found when comparing water-quality standards calculated on the basis of the hardness-based criterion for copper relative to those calculated using the Biotic Ligand Model (fig. 24). The hardness-based criteria suggest significant, but lower, toxicity in the Ely Brook watershed, similar toxicity in Schoolhouse Brook, and slightly higher toxicity in the Ompompanoosuc River compared to the Biotic Ligand Model criteria. Nevertheless, both approaches identify similar reaches of impairment, which are consistent with ecological indicators such as the number of riffle-habitat invertebrate taxa present (fig. 24).

Indicators of surface-water quality in the ponds along tributary 2 to Ely Brook were consistent. Ponds with impaired water quality exceeded both the acute and chronic criteria (ponds 4, 5, and 6), whereas pond 2 only minimally exceeded the chronic criterion $(\mathrm{HQ}=1.1)$. Qualitative multi-habitat measures of the number of taxa and the number of individuals showed systematic decreases relative to the reference site (pond 1).

Results of the whole-sediment toxicity tests for Ely Brook, Schoolhouse Brook, and the Ompompanoosuc River were generally consistent with other measures of biological impacts of sediment and pore water of streams draining the
Ely Mine site. Copper concentrations in sediments indicate impairment relative to probable effects concentrations at all sites in Ely Brook and Schoolhouse Brook, except the reference sites. In contrast, partitioning sediment benchmarks predict no toxicity at the reference sites and in the Ompompanoosuc River and uncertain toxicity at all others sites in Ely Brook and Schoolhouse Brook, except site EB-600M for which toxicity is predicted.

Acute toxicity tests conducted by the USEPA with pore waters sampled in situ at the time of whole sediment sampling indicated acute lethal effects on amphipods in pore waters from Ely Brook (including 100 percent lethality in EB-90M pore waters), where our test indicated no chronic toxicity, but the acute tests indicated no toxic effects of pore water from Schoolhouse Brook, where our chronic, whole-sediment tests found effects on both amphipods and midges (fig. 25). These differences may be due to two separate factors. The differences may reflect the greater sensitivity of the chronic tests, and they may also be due to an apparent loss of toxicity due to the neutralization of acidic EB-90M pore waters as an artifact of the chronic test protocol. Results of both sets of toxicity tests are consistent with surveys of resident benthic invertebrates at these study sites, which demonstrated severe effects on communities at sites downgradient of mining in Ely Brook and lesser effects in the Schoolhouse Brook study reach.

Significant toxic effects on amphipods (reduced survival and growth) and midges (reduced survival) occurred in sediments from Ely Brook. These toxic effects persisted throughout the reach of Schoolhouse Brook downstream of the confluence of Ely Brook, but there was no evidence of sediment toxicity in the Ompompanoosuc River downstream of the confluence of Schoolhouse Brook. Midge survival did not indicate significant toxic effects of these sediments, consistent with previous studies with metal-contaminated sediments that have reported that amphipod survival and midge growth are more sensitive endpoints than midge survival (Phipps and others, 1995; Besser and others, 2008). Within the affected reach, all sediment samples caused significant reductions of all three sensitive endpoints (relative to reference sites) except sediments from EB-90M, which were not toxic to either amphipods or midges, and sediments from SB-1360M, which were toxic to amphipods but not to midges (table 8).

The absence of toxic effects of the EB-90M sediment is remarkable, given the high total copper concentrations in this sediment and the high concentration of copper in the pore water. The lack of toxicity in the laboratory test with EB-90M sediments is probably related to the very acidic $\mathrm{pH}$ (2.9-3.2) of surface and pore waters collected from this site. The small fraction of total copper recovered in the SEM fraction (1.1 percent of total copper) suggests that almost all labile copper had been leached from the EB-90M sediment and that the high copper concentrations in EB-90M pore water originated from contaminated surface water or groundwater moving downgradient into the EB-90M sediments. Labile copper in the stream sediments is likely sorbed onto hydrated ferric hydroxides, which is strongly dependent upon $\mathrm{pH}$. Below a 


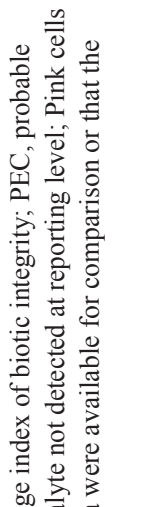

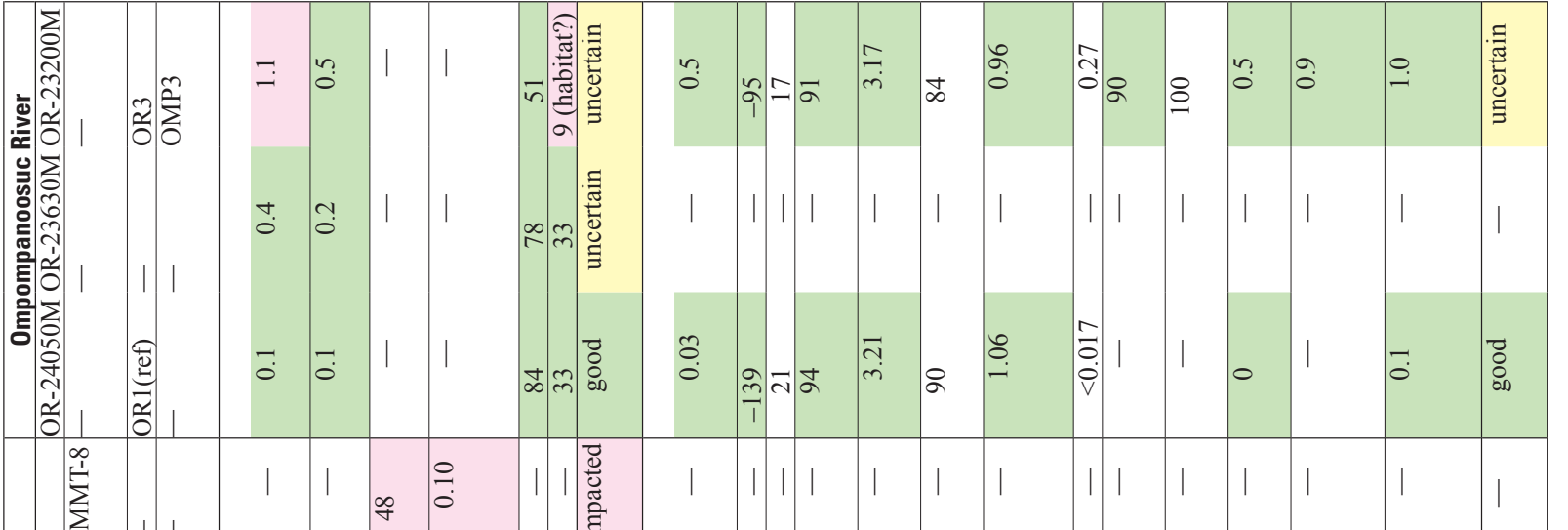

穴 需 $v$

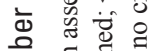

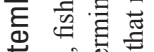

홍

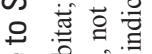

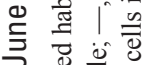

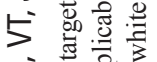

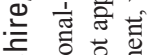

का

运范

造代

ते

氙魚

®

部宫品

พิ)

Ð 仓ั

들

중

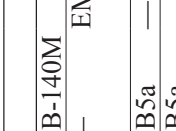

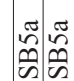

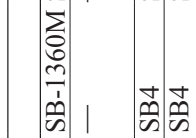

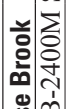

㝘

$\tilde{m}$

宓

厓 $\sum^{0}$

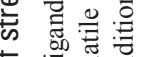

뭉

훙

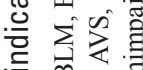

का

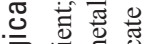

응 흐의을

을 矛垴

등

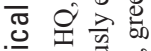

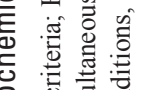

ब

颔焉可

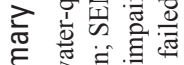

突

m ह

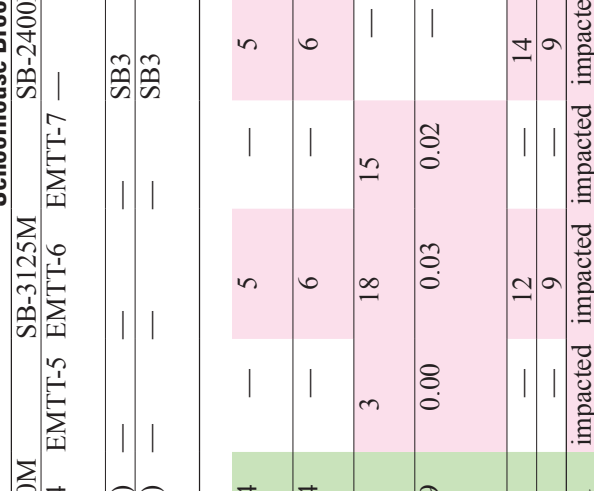

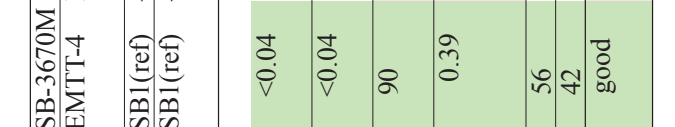

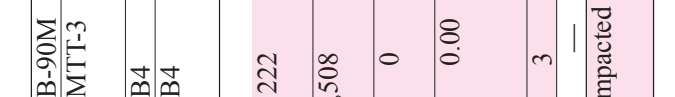

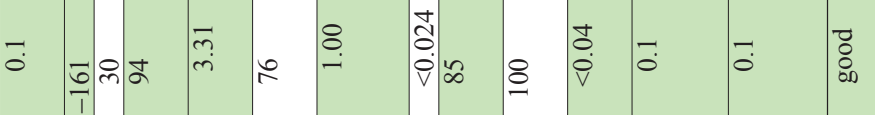

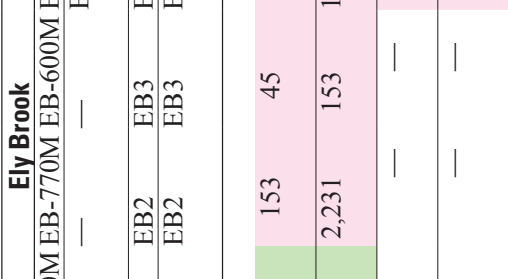

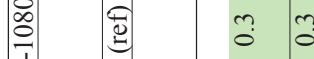

1 㺃

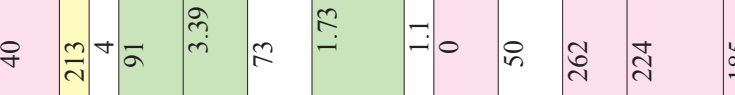

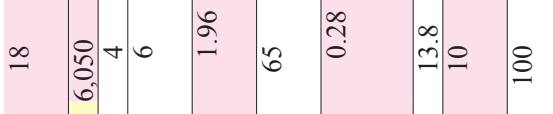

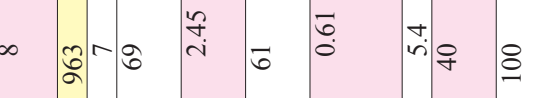

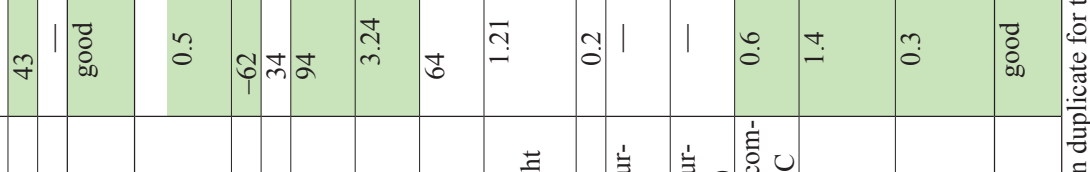

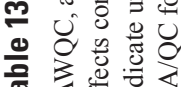

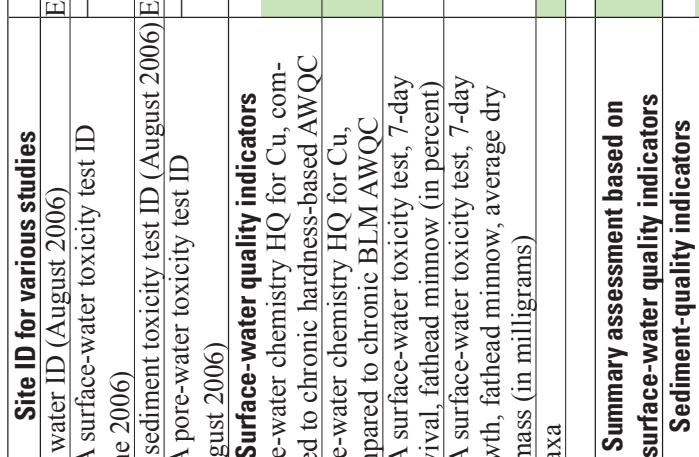

匹娄. 
Table 14. Summary of geochemical and biological indicators of pond health in the Ely Mine study area, Vershire, VT, June to September 2006.

[AWQC, ambient water-quality criteria; HQ, hazard quotient; BLM, Biotic Ligand Model; QMH, qualitative multi-habitat invertebrates index; PEC, probable effects concentration; - , not determined; Pink cells indicate uniformly impaired conditions, green cells indicate unimpaired conditions, yellow cells indicate uncertain level of impairment, white cells indicate that no criteria were available for comparison or that the QA/QC for the test failed]

\begin{tabular}{|c|c|c|c|c|c|c|}
\hline Site ID for various studies & & & & & & \\
\hline USGS water ID & Pond 1 & Pond 2 & Pond 3 & Pond 4 & Pond 5 & Pond 6 \\
\hline USEPA surface-water toxicity test ID & NA & NA & NA & EMTT-1 (ref) & EMTT-2 & NA \\
\hline $\begin{array}{l}\text { Surface-water chemistry HQ for } \mathrm{Cu} \text {, compared to chronic } \\
\text { hardness-based AWQC }\end{array}$ & 0.5 & 1.1 & 0.6 & 4.2 & 103 & 226.9 \\
\hline $\begin{array}{l}\text { USEPA surface-water toxicity test, 7-day survival, fathead } \\
\text { minnow (in percent) }\end{array}$ & - & - & - & 20 & 0 & - \\
\hline $\begin{array}{l}\text { USEPA surface-water toxicity test, 7-day growth, fathead } \\
\text { minnow, average dry biomass (in milligrams) }\end{array}$ & - & - & - & 0.03 & 0.00 & - \\
\hline QMH taxa & 59 & 46 & 47 & 26 & 14 & 2 \\
\hline $\begin{array}{l}\text { In situ wood frog tadpole survival } 1 \text { week after hatching } \\
\text { (in percent) }\end{array}$ & 86 & - & - & 38 & 0.0 & - \\
\hline Summary assessment based on surface-water exposure & good & uncertain & uncertain & impacted & impacted & impacted \\
\hline Sediment-quality indicators & & & & & & \\
\hline Bulk sediment chemistry $\mathrm{HQ}$ for $\mathrm{Cu}$, compared to PEC & 0.6 & 0.6 & 0.6 & 2.6 & 24 & 12 \\
\hline
\end{tabular}

$\mathrm{pH}$ of 4.0 to 4.5 , essentially all of the labile copper should be in solution, whereas above that range, copper sorbs strongly to ferric hydroxides (Seal and Hammarstrom, 2003). This effect is illustrated in figure 26. Figure $26 \mathrm{~A}$ shows the mass ratio of total $\mathrm{Cu}$ to total $\mathrm{Fe}$ in the sediment, and figure $26 B$ shows the mass ratio of SEM Cu to total $\mathrm{Fe}$ in the sediment. From EB-1080M to EB-600M, the pH varied between 6.3 and 7.2, and the amount of labile $\mathrm{Cu}$ increased with the total amount of $\mathrm{Cu}$. However, between sites EB-600M and EB-90M, the $\mathrm{pH}$ of Ely Brook dropped to 3.0. Although the ratio of total $\mathrm{Cu}$ to total $\mathrm{Fe}$ is high, the ratio of labile (SEM) $\mathrm{Cu}$ to total $\mathrm{Fe}$ is low, which is probably due to the mobility of labile $\mathrm{Cu}$ at low $\mathrm{pH}$ $(<4)$. The same trend is also reflected in the variation of labile (SEM) $\mathrm{Cu}$ to total $\mathrm{Cu}$ within the watershed (fig. 26B). In Ely Brook, the proportion of labile copper drops abruptly with $\mathrm{pH}$, but once $\mathrm{pH}$ increases in Schoolhouse Brook, the proportion of labile copper once again goes up, even though the amount of total copper is lower. Because of the $\mathrm{pH}$ dependence of the lability of copper, somewhere between sites EB-600M and EB-90M, the bioavailability of copper in the sediments dropped dramatically with decreasing $\mathrm{pH}$; the resulting limited bioavailbility persisted down to the confluence with Schoolhouse Brook. The acidic conditions have leached the labile copper and left a more refractory solid-phase copper species.
Due to the $\mathrm{pH}$ dependence of copper solubility and sorption (Dzomback and Morel, 1990; Nordstrom and Alpers, 1999), a hypothetical increase in $\mathrm{pH}$ due to remediation would only serve to sequester more strongly the copper and other trace metals in the sediments.

It is also possible that the sample of acidic, high-copper EB-90M pore water collected before the start of the sediment test was not representative of conditions during the toxicity tests. During the tests, the $\mathrm{pH}$ of EB-90M pore waters was apparently neutralized by regular replacement of the overlying water ( $\mathrm{pH} 8.2$, alkalinity $100 \mathrm{mg} / \mathrm{L}$ as $\mathrm{CaCO}_{3}$ ). Water-quality analyses of overlying water indicated slight depression of $\mathrm{pH}$ and alkalinity on day 0 of the test with EB-90M sediment but showed no difference from other sediments on subsequent dates. Once the high copper concentration in the original pore water was lost by dilution, precipitation, or sorption at neutral $\mathrm{pH}$, the pool of bioavailable copper in this sediment was apparently too low to sustain toxic levels of copper in pore water. In contrast, the EB-600M sediment, which had lower total copper concentrations and lower pore-water copper concentrations before the toxicity test, had concentrations of SEM copper that were more than tenfold greater than those in the EB-90M sediment. The EB-600M sediment caused severe toxic effects on both midges and amphipods. 


\section{Aquatic Assessment of the Ely Copper Mine Superfund Site, Vershire, Vermont}

Sediment toxicity testing and SEM-AVS determinations were not done in the ponds along Ely Brook tributary 2. Nevertheless, copper concentrations relative to probable effects concentrations are consistent with surface-water quality.

Ponds 4, 5 and 6 are impaired.

In general, the equilibrium-partitioning sediment benchmarks provide a more accurate assessment of sediment toxicity at the site than the PECs do. For example, both Hyalella

A

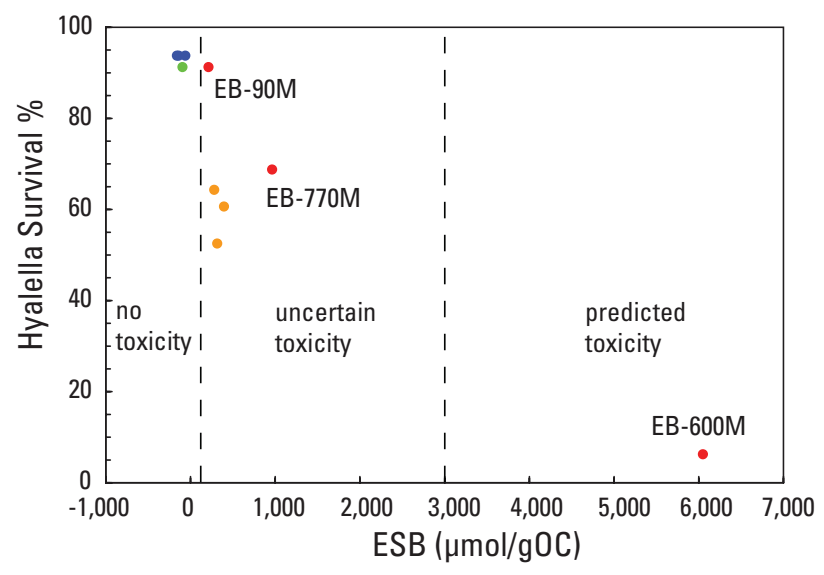

C

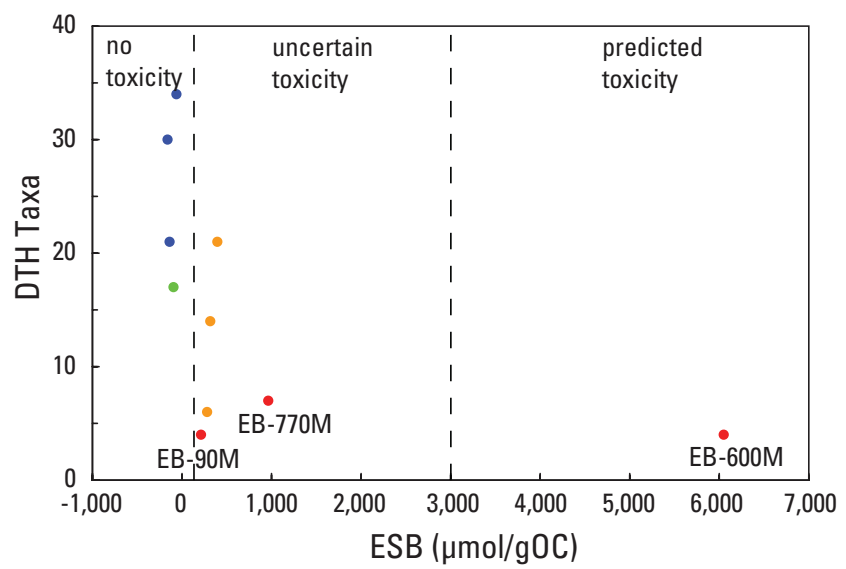

azteca survival in the toxicity tests and the depositional habitat taxa correlate strongly with ESB (fig. 27A,C). The copper PEC values do appear to accurately predict effects on the infauna community in the watershed (fig. 27D). In the sediment toxicity tests, the copper PEC values also predict $H$. azteca survival at HQs below 1, but toxic effects are not predicted well at values above 1 (fig. 27B).
B

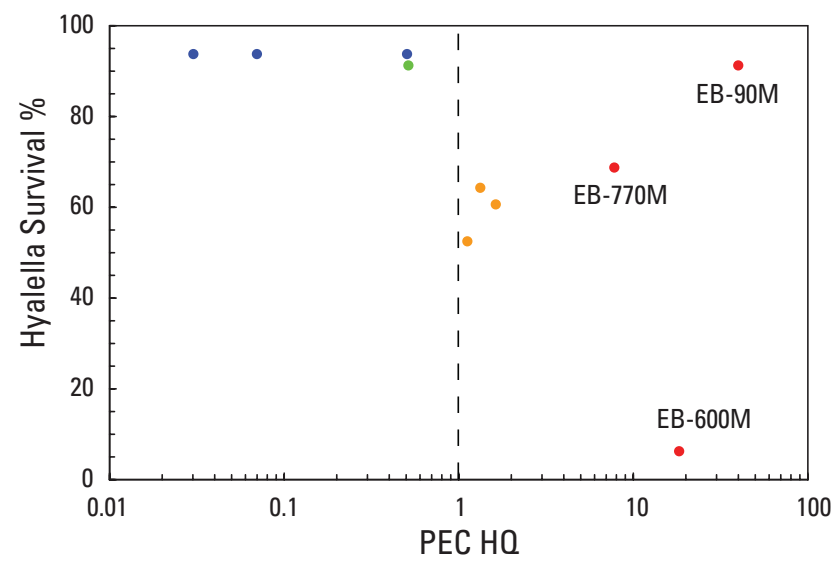

D

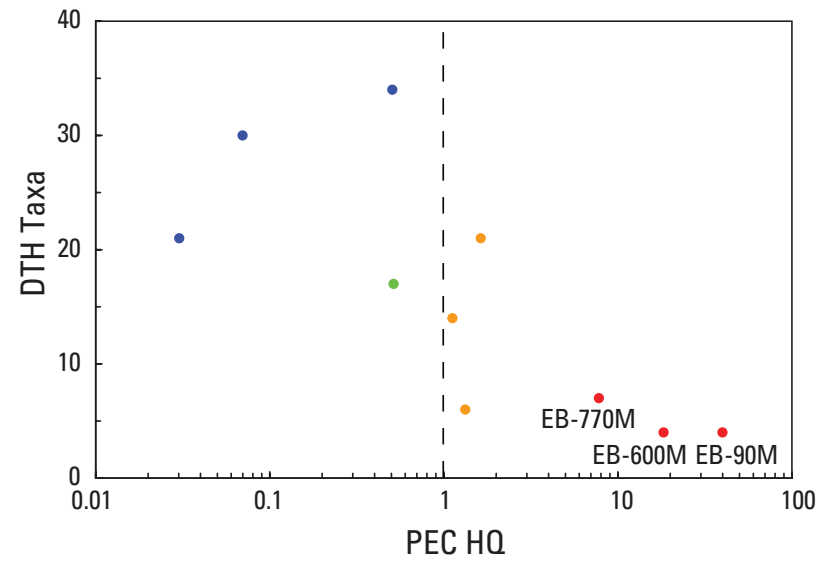

\footnotetext{
Explanation

- Reference

- Ely Brook

- Schoolhouse Brook

- Ompompanoosuc River
}

Figure 27. Comparison of sediment-quality criteria with various measures of sediment toxicity. $A$, The variation of Hyalella azteca survival in toxicity tests with the equilibrium-partitioning sediment benchmark (ESB). The boundaries between ESB ranges for no toxicity, uncertain toxicity, and predicted toxicity are from USEPA (2005). B, The variation of Hyalella azteca survival in toxicity tests with hazard quotients $(\mathrm{HO})$ based on the copper probable effects concentration (PEC). C, The variation of depositional-targeted habitiat (DTH) taxa richness with the equilibrium-partitioning sediment benchmark (ESB). The boundaries between ESB ranges for no toxicity, uncertain toxicity, and predicted toxicity are from USEPA (2005). D, The variation of depositional-targeted habitiat (DTH) taxa richness hazard quotients based on the copper probable effects concentration (PEC). 


\section{Conclusions}

In summary, the aquatic ecosystem at the site was assessed using a variety of approaches that investigated surface-water quality, sediment quality, and various ecological indicators of stream health. The degradation of surface-water quality is dominated by $\mathrm{Cu}$ with localized degradation caused by $\mathrm{Fe}, \mathrm{Al}, \mathrm{Cd}$, and $\mathrm{Zn}$. Chronic water-quality criteria for copper are exceeded by four of the six ponds on the Ely Brook tributary, all of Ely Brook and Schoolhouse Brook except for the reference sites, and only the most downstream site on the Ompompanoosuc River. Comparison of hardness-based and Biotic Ligand Model-based water-quality criteria for copper yields similar results with respect to extent of impairment. However, the Biotic Ligand Model criteria are more stringent than the hardness-based criteria and suggest a greater degree of impairment, particularly in the Ely Brook watershed, where dissolved organic carbon concentrations and $\mathrm{pH}$ values are lower. Surface-water toxicity testing correlates strongly with the extent of impact. Likewise, riffle-habitat benthic invertebrate richness and abundance data support these results through the stream environment. Similarly, the index of biotic integrity for the fish community in Schoolhouse Brook and the Ompompanoosuc River document degraded habitats throughout Schoolhouse Brook from Ely Brook down to the Ompompanoosuc River.

The sediment environment shows similar extents of impairment dominated by copper, although localized degradation due to $\mathrm{Cr}, \mathrm{Ni}, \mathrm{Pb}$, and $\mathrm{Zn}$ were documented on the basis of probable effects concentrations. In contrast, equilibriumpartitioning sediment benchmarks indicate no toxic effects would be expected in sediments at the reference sites, and uncertain toxic effects expected throughout Ely Brook and Schoolhouse Brook, except for site EB-600M. The results for site EB-600M indicate predicted toxic effects. Acute toxicity testing of in situ pore waters using Hyalella azteca indicates severe impacts in Ely Brook reaching 100 percent lethality at EB-90M. Acute toxicity testing of in situ pore waters using Chironomus dilutus shows similar, but not as severe, toxicity. Neither set of in situ pore-water toxicity tests showed significant impairment in Schoolhouse Brook or the Ompompanoosuc River. Chronic sediment toxicity testing using Hyalella azteca indicated significant toxicity in Ely Brook, except at EB-90M, and in Schoolhouse Brook. The low toxicity of EB$90 \mathrm{M}$ may be a reflection of the low lability of copper in that sediment, as indicated by a low proportion of extractable copper (1.1 percent). Toxicity testing was not done with the pond pore waters or sediments. Depositional habitat invertebrate richness and abundance data support these conclusions, as do the index of biotic integrity data from the fish community.

In general, degraded surface-water quality, particularly from copper, appears to be the dominant cause of toxicity at the site. Sediment quality is less uniformly affected, particularly downstream of Ely Brook; however, copper is also the dominant contaminant of concern in this medium.

\section{References Cited}

Abbott, Collamer, 1973, Green Mountain copper-The story of Vermont's red metal: Thetford, VT, Thetford Historical Society, $36 \mathrm{p}$.

Agency for Toxic Substances and Disease Registry, 2008, Public health assessment—Ely copper mine site, Vershire, VT: Agency for Toxic Substances and Disease Registry, 29 p., 3 apps.

American Society for Testing and Materials, 2007, ASTM E1706-05 Standard-Test method for measuring the toxicity of sediment-associated contaminants with freshwater invertebrates: West Conshohocken, PA, ASTM International, $118 \mathrm{p}$.

Arcement, G.J., Jr., and Schneider, V.R., 1989, Guide for selecting Manning's roughness coefficients for natural channels and flood plains: U.S. Geological Survey Water-Supply Paper 2339, 38 p.

Argue, D.M., Kiah, R.G., Piatak, N.M., Seal, R.R., II, Hammarstrom, J.M., Hathaway, Edward, and Coles, J.F., 2008, Selected water- and sediment-quality, aquatic biology, and mine-waste data from the Ely Copper Mine Superfund site, Vershire, VT, 1998-2007: U.S. Geological Survey Data Series 378, available online only at http://pubs.usgs.gov/ $d s / 378 /$

Besser, J.M., Brumbaugh, W.G., Ivey, C.D., Ingersoll, C., and Moran, P.W., 2008, Biological and chemical characterization of metal bioavailability in sediments from Lake Roosevelt, Columbia River, Washington, USA: Archives of Environmental Contamination and Toxicology, v. 54, no. 4, p. 557-570.

Buchanan, T.J., and Somers, W.P., 1969, Discharge measurements at gaging stations: U.S. Geological Survey Techniques of Water-Resources Investigations, book 3, chap. A8, $65 \mathrm{p}$.

Buerger, N.W., 1935, The copper ores of Orange County, Vermont: Economic Geology, v. 30, no. 4, p. 434-443.

Cherau, S.G., Ford, B., and Kierstead, M., 2005, Historical/ archaeological mapping and testing-Ely mine site, volume 1: Public Archaeology Laboratory Incorporated Report No. 1386,434 p.

Crawford, J.K., and Luoma, S.N., 1993, Guidelines for studies of contaminants in biological tissues for the National WaterQuality Assessment Program: U.S. Geological Survey Open-File Report 92-0494, 69 p. 
Di Toro, D.M., McGrath, J.M., Hansen, D.J., Berry, W.J., Paquin, P.R., Mathew, R., Wu, K.B., and Santore, R.C., 2005, Predicting sediment metal toxicity using a sediment biotic ligand model-Methodology and initial application: Environmental Toxicology and Chemistry, v. 24, no. 10, p. 2410-2427.

Dzombak, D.A., and Morel, F.M.M., 1990, Surface complexation modeling-Hydrous ferric oxide: New York, John Wiley and Sons, 393 p.

Fitzpatrick, F.A., Waite, I.R., D’Arconte, P.J., Meador, M.R., Maupin, M.A., and Gurtz, M.E., 1998, Revised methods for characterizing stream habitat in the National Water-Quality Assessment Program: U.S. Geological Survey WaterResources Investigations Report 98-4052, 67 p.

Fuller, C.C., and Harvey, J.W., 2000, Reactive uptake of trace metals in the hyporheic zone of a mining-contaminated stream, Pinal Creek, Arizona: Environmental Science and Technology, v. 34, no. 7, p. 1150-1155.

Hammarstrom, J.M., Seal, R.R., II, Meier, A.L., and Jackson, J.C., 2003, Weathering of sulfidic shale and copper mine waste: Secondary minerals and metal cycling in Great Smoky Mountains National Park, Tennessee and North Carolina, USA: Environmental Geology, v. 45, no. 1, p. 35-57.

Hammarstrom, J.M., Seal, R.R., II, Ouimette, A.P., and Foster, S.A., 2001a, Sources of metals and acidity at the Elizabeth and Ely mines - Geochemistry and mineralogy of solid mine waste and the role of secondary minerals in metal recycling, in Hammarstrom, J.M., and Seal, R.R., II, eds., Environmental geochemistry and mining history of massive sulfide deposits in the Vermont Copper Belt: Society of Economic Geologists Guidebook Series, v. 35, p. 213-248.

Hammarstrom, J.M., Seal, R.R., II, Slack, J.F., Kierstead, M.A., and Hathaway, E.M., 2001b, Field trip days 1 and 2: Road $\log$ for the Elizabeth and Ely mines and vicinity, in Hammarstrom, J.M., and Seal, R.R., II, eds., Environmental geochemistry and mining history of massive sulfide deposits in the Vermont Copper Belt: Society of Economic Geologists Guidebook Series, v. 35, p. 119-163.

Harvey, J.W., and Fuller, C.C., 1998, Effect of enhanced manganese oxidation in the hyporheic zone on basin-scale geochemical mass balance: Water Resources Research, v. 34, no. 4, p. 623-636.

Helsel, D.R., 2005, Nondetects and data analysis: Statistics for censored environmental data: New York, John Wiley and Sons, 268 p.

Helsel, D.R., and Cohn, T.A., 1988, Estimation of descriptive statistics for multiply censored water quality data: Water Resources Research, v. 24, no. 12, p. 1997-2004.

Helsel, D.R., and Hirsch, R.M., 1992, Statistical methods in water resources: New York, Elsevier Science Publishers, 522 p.
Hermance, H.P., Neumann, G.L., and Moiser, M., 1949, Investigation of Ely Mine copper deposit, Orange County, Vt.: U.S. Bureau of Mines Report of Investigations 4395, 11 p.

Holmes, J.V., Bigl, S.R., Lawson, D.E., Seal, R.R., and Piatak, N.M., 2002, Spring runoff characterization, Ely Mine, Vershire, Vermont, Spring 2002: Hanover, NH, Cold Regions Research and Engineering Laboratory, ERDC/CRREL Letter Report LR-02-65.

Ingersoll, C.G., MacDonald, D.D., Wang, N., Crane, J.L., Field, L.J., Haverland, P.S., Kemble, N.E., Lindskoog, R.A., Severn, C., and Smorong, D.E., 2001, Predictions of sediment toxicity using consensus-based freshwater-sediment quality guidelines: Archives of Environmental Contamination and Toxicology, v. 41, no. 1, p. 8-21.

Kiah, R.G., Deacon, J.R., Piatak, N.M., Seal, R.R., II, Coles, J.F., and Hammarstrom, J.M., 2007, Surface-water hydrology and quality at the Pike Hill Superfund Site, Corinth, Vermont, October 2004 to December 2005: U.S. Geological Survey Scientific Investigations Report 2007-5003, 61 p.

Kierstead, M.A., 2001, History and historical resources of the Vermont Copper Belt, in Hammarstrom, J.M., and Seal, R.R., II, eds., Environmental geochemistry and mining history of massive sulfide deposits in the Vermont Copper Belt: Society of Economic Geologists Guidebook Series, v. 35, p. 165-191.

Kilpatrick, F.A., and Schneider, V.R., 1983, Use of flumes in measuring discharge: U.S. Geological Survey Techniques of Water-Resources Investigations, book 3, chap. A14, 46 p.

Koretsky, C.M., Johnson, R.H., Miller, Douglas, and Ndenga, N.T., 2006, Seasonal variations in pore water and sediment geochemistry of littoral lake sediments (Asylum Lake, MI, USA): Geochemical Transactions, v. 7, no. 11.

Long, E.R., and Chapman, P.M., 1985, A sediment quality triad-Measures of sediment contamination, toxicity and infaunal community composition in Puget Sound: Marine Pollution Bulletin, v. 16, no. 10, p. 405-415.

MacDonald, D.D., Ingersoll, C.G., and Berger, T.A., 2000, Development and evaluation of consensus-based sediment quality guidelines for freshwater ecosystems: Archives of Environmental Contamination and Toxicology, v. 39, no. 1, p. 20-31.

McSurdy, S., Dvorak, D., and Cooper, A., 1995, Ely mine site report of activities - Experimental passive mine water treatment system: Pittsburgh, PA, U.S. Bureau of Mines, 51 p.

Moulton, S.R., Kennan, J.G., Goldstein, R.M., and Hambrook, J.A., 2002, Revised protocols for sampling algal, invertebrate, and fish communities as part of the National WaterQuality Assessment Program: U.S. Geological Survey Open-File Report 02-150, 75 p. 
Nordstrom, D.K., and Alpers, C.N., 1999, Geochemistry of acid mine waters, in Plumlee, G.S., and Logsdon, M.J., eds., The environmental geochemistry of mineral deposits, Part A. Processes, techniques, and health issues: Reviews in Economic Geology, 6A, p. 133-160 (Chapter 6).

Offield, T.W., Slack, J.F., and Wittinbrink, S.A., 1993, Structure and origin of the Ely copper deposit, east-central Vermont: U.S. Geological Survey Bulletin 2039, p. 59-68.

Olson, S.A., Flynn, R.H., Johnston, C.M., and Tasker, G.D., 2005, The New Hampshire Watershed Tool: A geographic information system tool to estimate statistics and groundwater-recharge rates: U.S. Geological Survey Open-File Report 2005-1172, 20 p.

Paquin, P.R., Gorsuch, J.W., Apte, Simon, Batley, G.E., Bowles, K.C., Campbell, P.G.C., Delos, C.G., Di Toro, D.M., Dwyer, R.L., Galvez, Fernando, Gensemer, R.W., Goss, G.G., Hogstrand, Christer, Janssen, C.R., McGeer, J.C., Naddy, R.B., Playle, R.C., Santore, R.C., Schneider, Uwe, Stubblefield, W.A., Wood, C.M., and Wu, K.B., 2002, The biotic ligand model-A historical overview: Comparative Biochemistry and Physiology, v. 133, no. 1-2, p. 3-35.

Phipps, G.L., Mattson, V.R., and Ankley, G.T., 1995, Relative sensitivity of three freshwater benthic macroinvertebrates to ten contaminants: Archives of Environmental Contamination and Toxicology, v. 28, no. 3, p. 281-286.

Piatak, N.M., Seal, R.R., II, Hammarstrom, J.M., Meier, A.L., and Briggs, P.H., 2003, Geochemical characterization of slags, other mine waste, and their leachate from the Elizabeth and Ely mines (Vermont), the Ducktown mining district (Tennessee), and the Clayton smelter site (Idaho): U.S. Geological Survey Open-File Report 2003-260, 53 p.

Piatak, N.M., Hammarstrom, J.M., Seal, R.R., II, Briggs, P.H., Meier, A.L., Muzik, T.L., and Jackson, J.C., 2004, Geochemical characterization of mine waste at the Ely copper mine Superfund site, Orange County, Vermont: U.S. Geological Survey Open-File Report 2004-1248, 55 p.

Piatak, N.M., Seal, R.R., II, Hammarstrom, J.M., Kiah, R.G., Deacon, J.R., Adams, Monique, Anthony, M.W., Briggs, P.H., and Jackson, J.C., 2006, Geochemical characterization of mine waste, mine drainage, and stream sediments at the Pike Hill Copper Mine Superfund Site, Orange County, Vermont: U.S. Geological Survey Scientific Investigations Report 2006-5303, 131 p.

Rantz, S.E., and others, 1982, Measurement and computation of streamflow, volume 1-Measurement of stage and discharge: U.S. Geological Survey Water-Supply Paper 2175, 284 p.

SAS Institute, Inc., 1998, Statview user's guide, version 5: Cary, NC, SAS Institute Inc., 528 p.
Sauer, V.B., and Meyer, R.W., 1992, Determination of error in individual discharge measurements: U.S. Geological Survey Open-File Report 92-144, 21 p.

Seal, R.R., II, and Hammarstrom, J.M., 2003, Geoenvironmental models of mineral deposits - Examples from massive sulfide and gold deposits, in Jambor, J.L., Blowes, D.W., and Ritchie, A.I.M., eds., Environmental aspects of mine wastes: Mineralogical Association of Canada Short Series, v. 31, p. 11-50.

Seal, R.R., II, Kornfeld, J.M., Meier, A.L., and Hammarstrom, J.M., 2001, Geochemical settings of mine drainage in the Vermont Copper Belt, in Hammarstrom, J.M., and Seal, R.R., II, eds., Environmental geochemistry and mining history of massive sulfide deposits in the Vermont Copper Belt: Society of Economic Geologists Guidebook Series, v. 35, p. 255-276.

Shelton, L.R., and Capel, P.D., 1994, Guidelines for collecting and processing samples of stream bed sediment for analysis of trace elements and organic contaminants for the National Water-Quality Assessment Program: U.S. Geological Survey Open-File Report 94-0458, 20 p.

Slack, J.F., Offield, T.W., Shanks, W.C., III, and Woodruff, L.G., 1993, Besshi-type massive sulfide deposits of the Vermont Copper Belt: Society of Economic Geologists Field Trip Guidebook Series, v. 17, p. 32-73.

Slack, J.F., Offield, T.W., Woodruff, L.G., and Shanks, W.C., III, 2001, Geology and geochemistry of Besshi-type massive sulfide deposits of the Vermont Copper Belt, in Hammarstrom, J.M., and Seal, R.R., II, eds., Environmental geochemistry and mining history of massive sulfide deposits in the Vermont Copper Belt: Society of Economic Geologists Field Trip Guidebook Series, v. 35, p. 193-211.

Smyth, H.L., and Smith, P.S., 1904, The copper deposits of Orange County, Vermont: Engineering and Mining Journal, v. 77 , no. 17 , p. $677-678$.

Spahr, N.E., and Boulger, R.W., 1997, Interim results of quality-control sampling of surface water for the upper Colorado River National Water-Quality Assessment Study Unit, water years 1995-96: U.S. Geological Survey WaterResources Investigations Report 97-4227, 34 p.

Suter, G.W., II, 1996, Toxicological benchmarks for screening contaminants of potential concern for effects on freshwater biota: Environmental Toxicology and Chemistry, v. 15, no. 7 , p. 1232-1241.

Taggart, J.E., Jr., ed., 2002, Analytical methods for chemical analysis of geologic and other materials, U.S. Geological Survey: U.S. Geological Survey Open-File Report 2002-223, variously paginated. 
TechLaw, Inc., 2006a, Two-species, 96-hour, acute toxicity testing results using pore water samples collected from the Ely Mine in Vershire, VT. Environmental Services Assistance Team (ESAT) report submitted to the U.S. Environmental Protection Agency, Office of Environmental Measurement and Evaluation, October 12, 2006.

TechLaw, Inc., 2006b, Toxicity testing results using surface water samples collected from the Pike Hill Mine in Corinth, VT, and the Ely Mine in Vershire, VT. Environmental Services Assistance Team (ESAT) report submitted to the U.S. Environmental Protection Agency, Office of Environmental Measurement and Evaluation, August 10, 2006.

TechLaw, Inc., 2008, Aquatic baseline ecological assessment-Ely copper mine Superfund site, Vershire, Vermont: Lowell, MA, TechLaw, Inc., variously paginated.

Tonkin, J.W., Balistrieri, L.S., and Murray, J.W., 2004, Modeling sorption of divalent metal cations on hydrous manganese oxide using the diffuse double layer model: Applied Geochemistry, v. 19, no. 1, p. 29-53.

URS Corporation, 2009, Phase 1A remedial investigation report, Ely mine, Vershire, Vermont: Portland, ME, URS, variously paginated.

U.S. Environmental Protection Agency, 1986, Guidelines for the health risk assessment of chemical mixtures: U.S. Environmental Protection Agency 630/R-98/002: Federal Register, v. 51, no. 185, p. 34014-34025.

U.S. Environmental Protection Agency, 2000, Methods for measuring the toxicity and bioaccumulation of sedimentassociated contaminants with freshwater invertebrates: U.S. Environmental Protection Agency 600/R-94/024, $192 \mathrm{p}$.

U.S. Environmental Protection Agency, 2004, National recommended water quality criteria: Washington, DC, U.S. Environmental Protection Agency, $22 \mathrm{p}$.

U.S. Environmental Protection Agency, 2005, Procedures for the derivation of equilibrium partitioning sediment benchmarks (ESBs) for the protection of benthic organismsMetal mixtures (cadmium, copper, lead, nickel, silver, and zinc): U.S. Environmental Protection Agency 600-R-02-011, variously paginated.

U.S. Environmental Protection Agency, 2006, National recommended water quality criteria, accessed March 2006, at http://www.epa.gov/waterscience/criteria/wqcriteria.html
U.S. Environmental Protection Agency, 2007, Aquatic life ambient freshwater quality criteria - Copper 2007 revision: U.S. Environmental Protection Agency 822-F-07-001, 49 p.

Vermont Department of Environmental Conservation, 2004, Biocriteria for fish and macroinvertebrate assemblages in Vermont wadeable streams and rivers, accessed April 2007, at $h t t p: / / w w w . v t w a t e r q u a l i t y . o r g / b a s s / d o c s /$ bs_wadeablestream2.pdf

Vermont Department of Environmental Conservation, 2006, Water Quality Division field methods manual, accessed June 2006, at http://www.anr.state.vt.us/dec/waterq/bass/ docs/bs_fieldmethodsmanual.pdf

Vermont Department of Environmental Conservation, 2008, Aquatic life use attainment assessment of streams influenced by the Ely Mine site, Vermont: Ompompanoosuc River, Schoolhouse Brook, and Schoolhouse Brook Tributary 3: Waterbury, VT, Vermont Department of Environmental Conservation.

Vermont Natural Resources Board, 2006, Vermont water quality standards, accessed April 2007, at http://www.nrb.state. vt.us/wrp/publications/wqs.pdf

Weed, W.H., 1911, Copper deposits of the Appalachian States: U.S. Geological Survey Bulletin 455, 166 p.

Wheeler, H.A., 1883, The copper deposits of Vermont: School of Mines Quarterly, v. 4, no. 3, p. 219-224.

White, W.S., and Eric, J.H., 1944, Preliminary report on the geology of the Orange County copper district, Vermont: U.S. Geological Survey Open-File Report 44-19, 36 p.

Wilde, F.D., and Radtke, D.B., eds., 1998, Field measurements: U.S. Geological Survey Techniques of Water-Resources Investigations, book 9, chap. A6, variously paginated.

Wilde, F.D., Radtke, D.B., Gibs, J., and Iwatsubo, R.T., eds., 1999, Collection of water samples: U.S. Geological Survey Techniques of Water-Resources Investigations, book 9, chap. A4, $156 \mathrm{p}$.

Zimmerman, M.J., Massey, A.J., and Campo, K.W., 2005, Pushpoint sampling for defined spatial and temporal variations in contaminant concentrations in sediment pore water near the ground water/surface water interface: U.S. Geological Survey Scientific Investigations Report 2005-5036, 75 p. 


\section{Appendixes 1-8}

1. Summary of test conditions for sediment toxicity tests with sediments from the Ely Mine site, September 2006, conducted in accordance with USEPA (2000) and ASTM (2007) standard methods .

2. Quality-assurance, quality-control water samples for the Ely Mine study, Vershire, VT

3. Quality-assurance, quality-control sediment samples for the Ely Mine study, Vershire, VT

4. Acid volatile sulfide, simultaneously extractable metals, and particle-size results for stream sediments and quality-assurance, quality-control samples for the Ely Mine study area, Vershire, VT .

5. Summary of select constituents in surface waters relative to ambient water-quality criteria for stream reaches in the Ely Mine study area, Vershire, VT, 2000 to 2007

6. Constituents in surface waters collected in August and September 2006 from the Ely Mine study area, Vershire, VT. 113

7. Constituents in pore waters collected in August and September 2006 from the Ely Mine study area, Vershire, VT

8. Chemistry results for sediments collected in August and September 2006 from the Ely Mine study area, Vershire, VT 

Appendix 1. Summary of test conditions for sediment toxicity tests with sediments from the Ely Mine site, September 2006, conducted in accordance with USEPA (2000) and ASTM (2007) standard methods.

\begin{tabular}{|c|c|}
\hline Test type & Whole-sediment toxicity tests \\
\hline Temperature & $23{ }^{\circ} \mathrm{C}$ \\
\hline Lighting & 16 hours light: 8 hours dark; wide-spectrum fluorescent, about 200 lux \\
\hline Test sediments & $\begin{array}{l}\text { Ely Mine sediments (11 samples, including reference sites) and laboratory control } \\
\text { (soil from Florissant, MO) }\end{array}$ \\
\hline Exposure chambers & 300-ml high-form beaker (with $100 \mathrm{~mL}$ sediment) \\
\hline Test water & Diluted Columbia Environmental Research Center (CERC) well water (target hardness $100 \mathrm{mg} / \mathrm{L}$ ) \\
\hline Water renewal & 2 volume-additions per day \\
\hline Test organisms & Amphipod, Hyalella azteca; Midge, Chironomus dilutus \\
\hline Age of organisms & Amphipods, about 8 days old; midge larvae, about 10 days old (second instar) \\
\hline Number of organisms & 10 per replicate \\
\hline Replication & 8 replicates of each species per sediment \\
\hline Feeding & $\begin{array}{l}\text { Amphipods: } 6 \mathrm{mg} \text { yeast-cerophyll-trout chow (YCT) per day (USEPA, 2000) } \\
\text { Midges, } 6 \mathrm{mg} \text { flake fish food suspension per day }\end{array}$ \\
\hline Water quality & Dissolved oxygen, conductivity, pH, alkalinity, hardness, ammonia (biweekly in overlying water) \\
\hline Sediment analyses & $\begin{array}{l}\text { Sediment: particle-size distribution, total organic carbon, total metals, simultaneously extractable } \\
\text { metals, acid-volatile sulfides } \\
\text { Pore water: dissolved metals, dissolved organic carbon }\end{array}$ \\
\hline Test duration & 28 days (amphipods); 10 days (midges) \\
\hline Test endpoints & $\begin{array}{l}\text { Amphipods: survival and growth (length) } \\
\text { Midges: survival and growth (ash-free dry weight) }\end{array}$ \\
\hline Test acceptability & Control survival: $\geq 80$ percent for amphipods, $\geq 70$ percent for midges \\
\hline
\end{tabular}





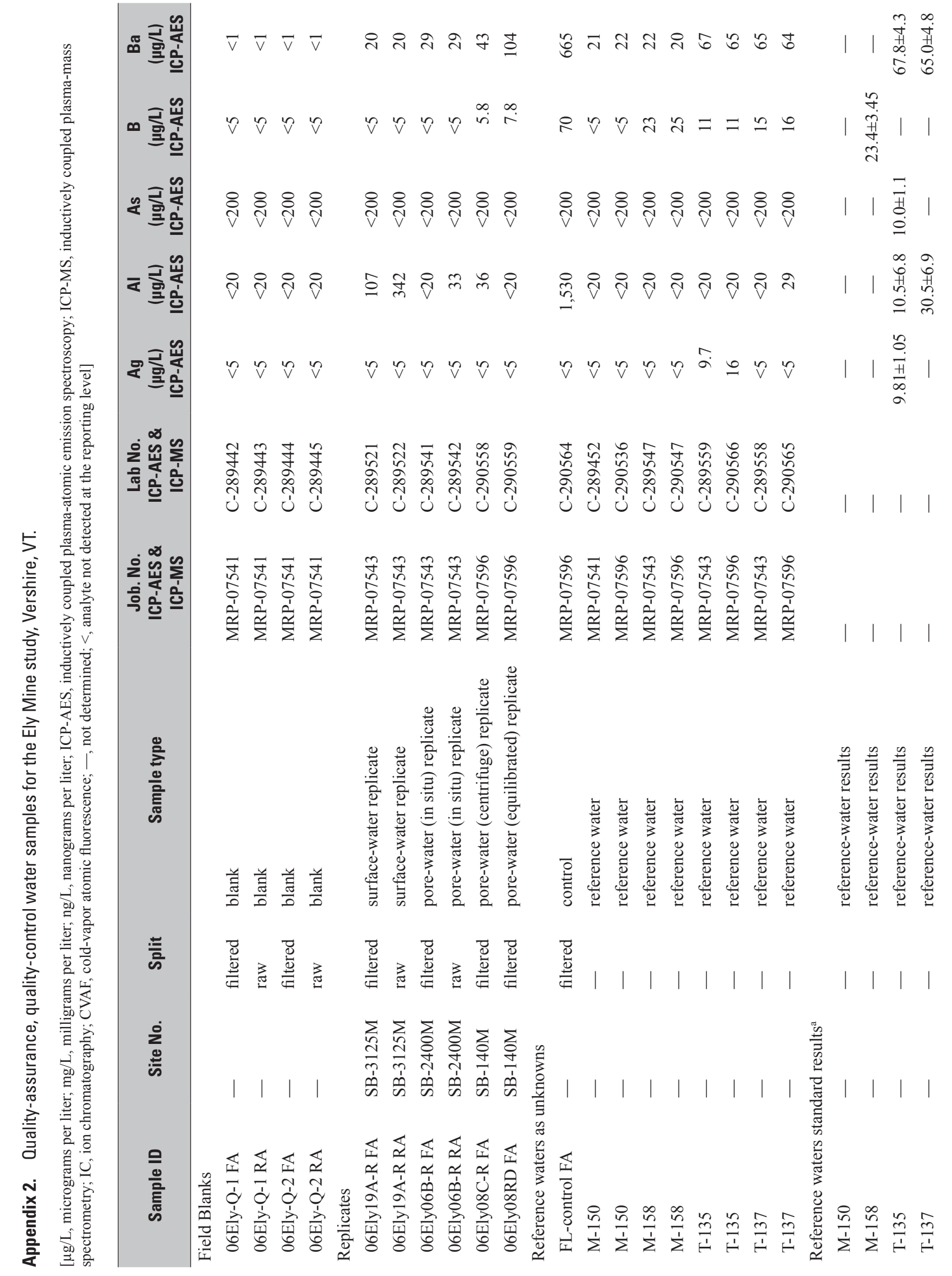




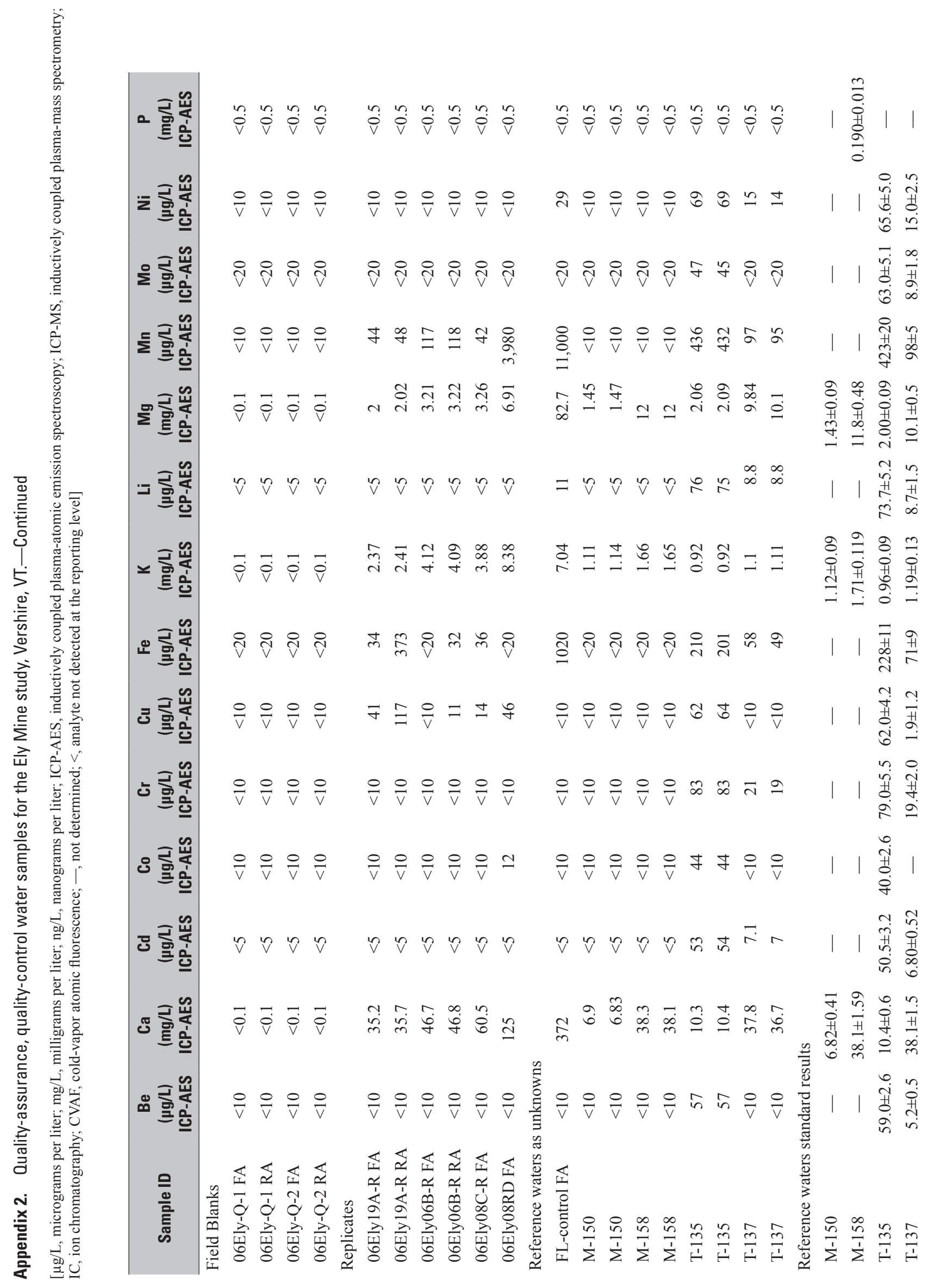




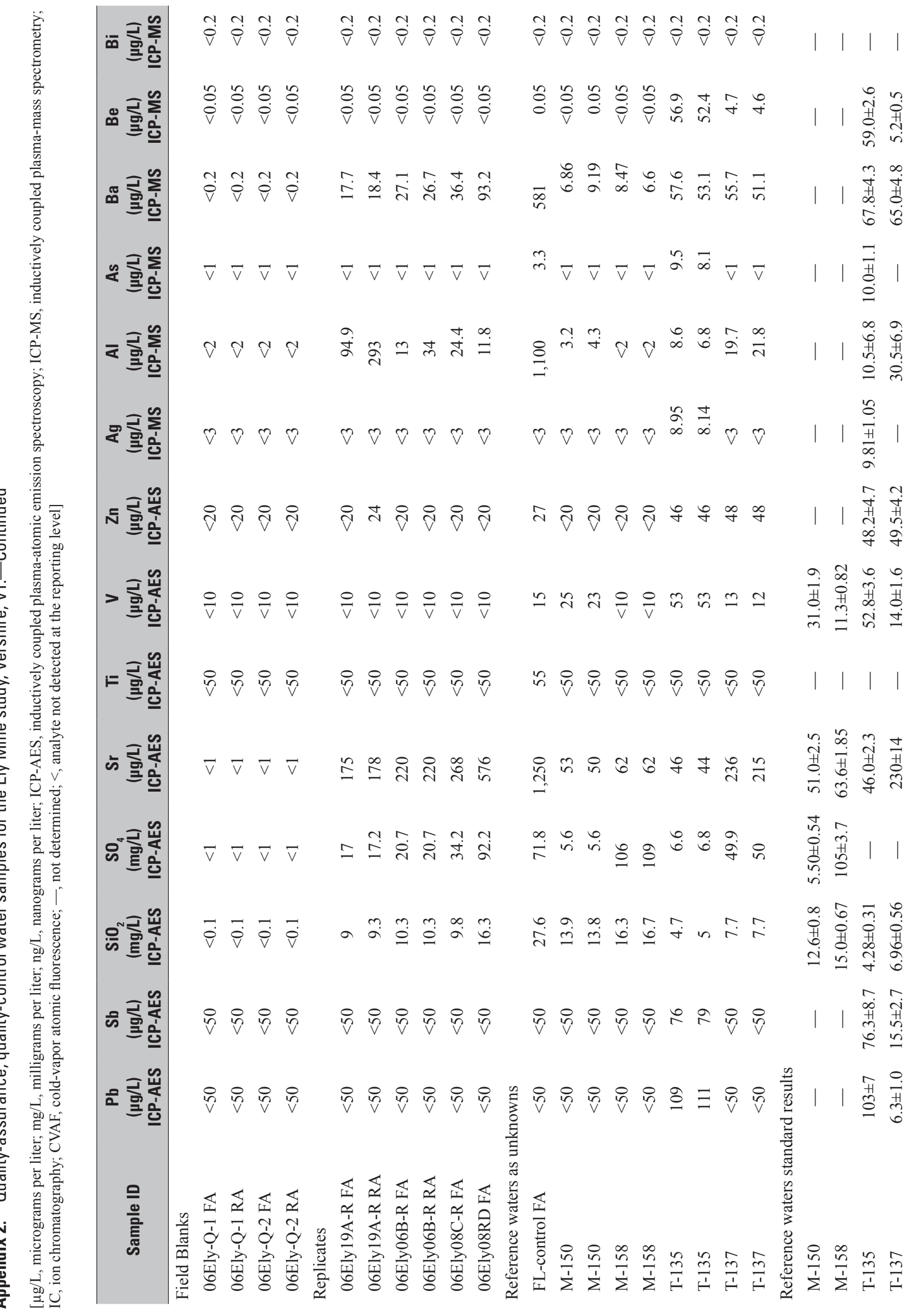




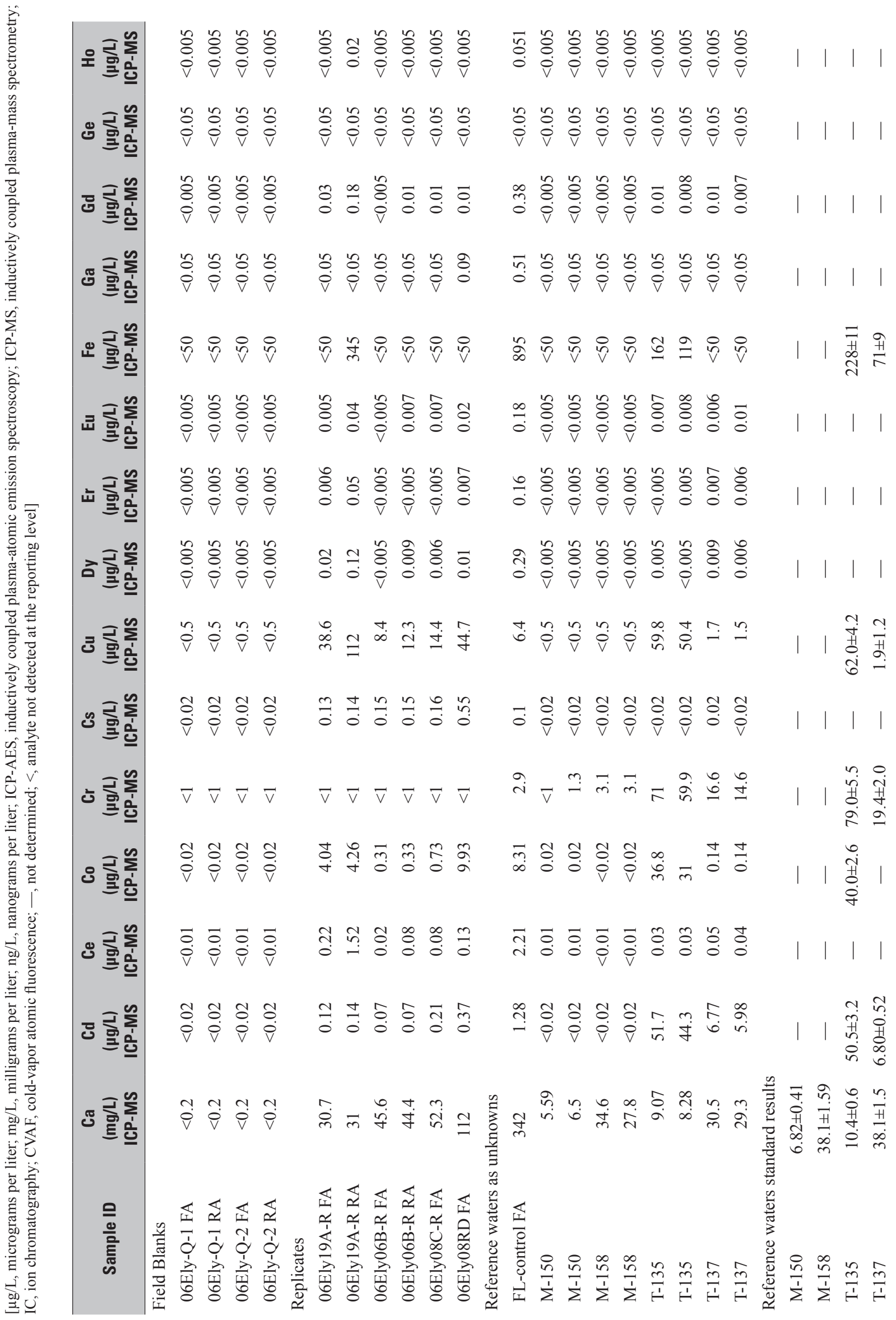




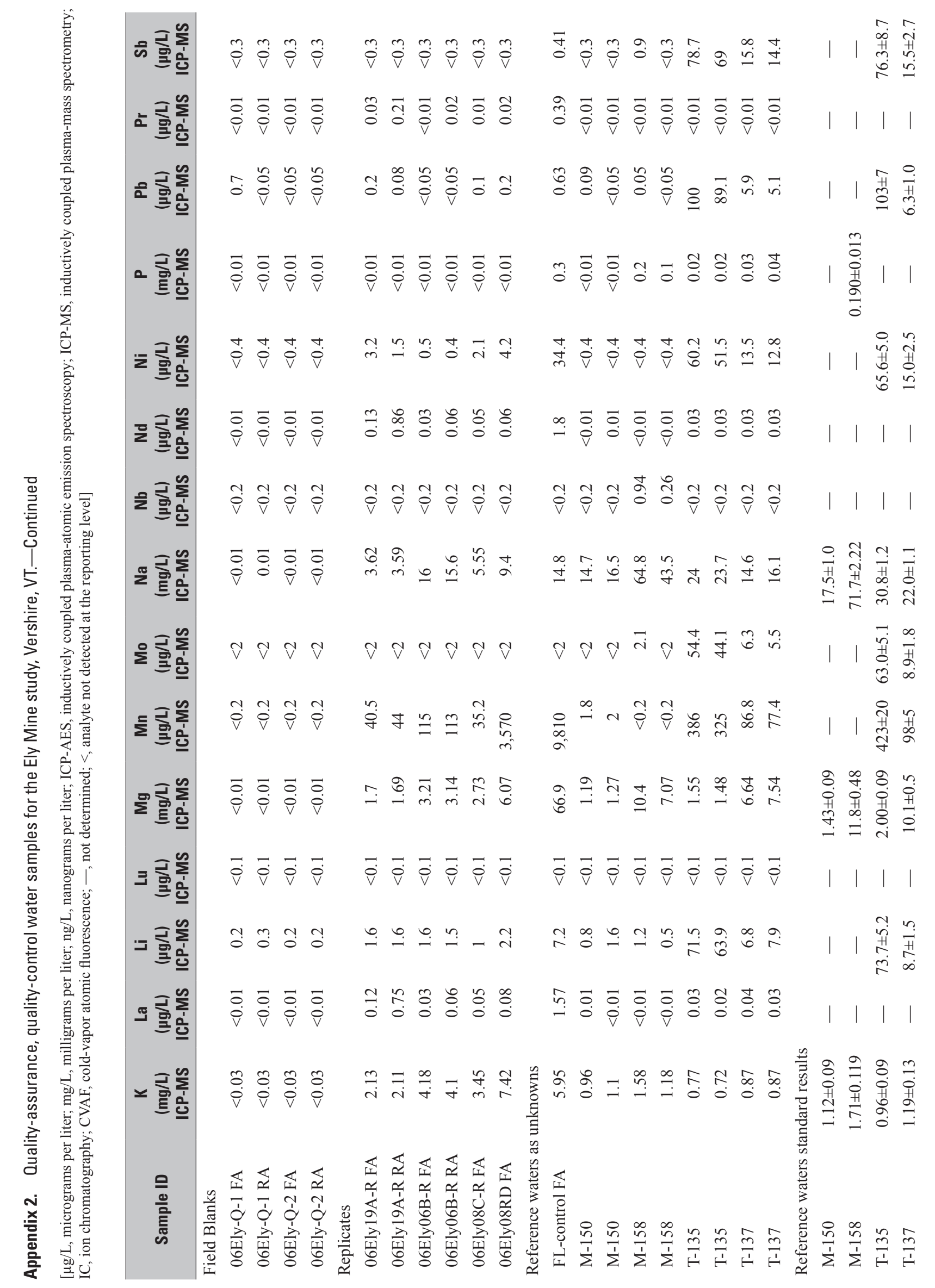




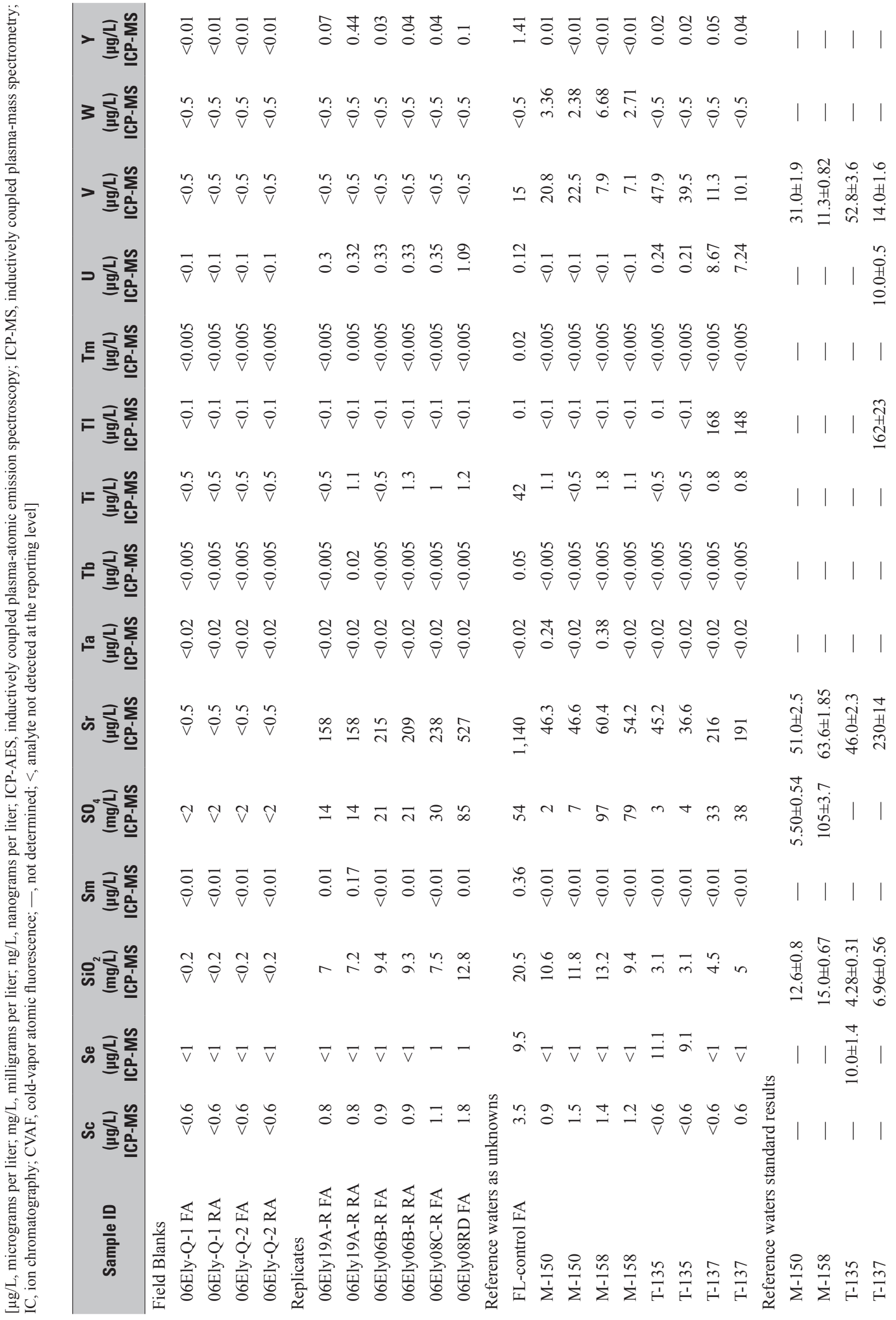




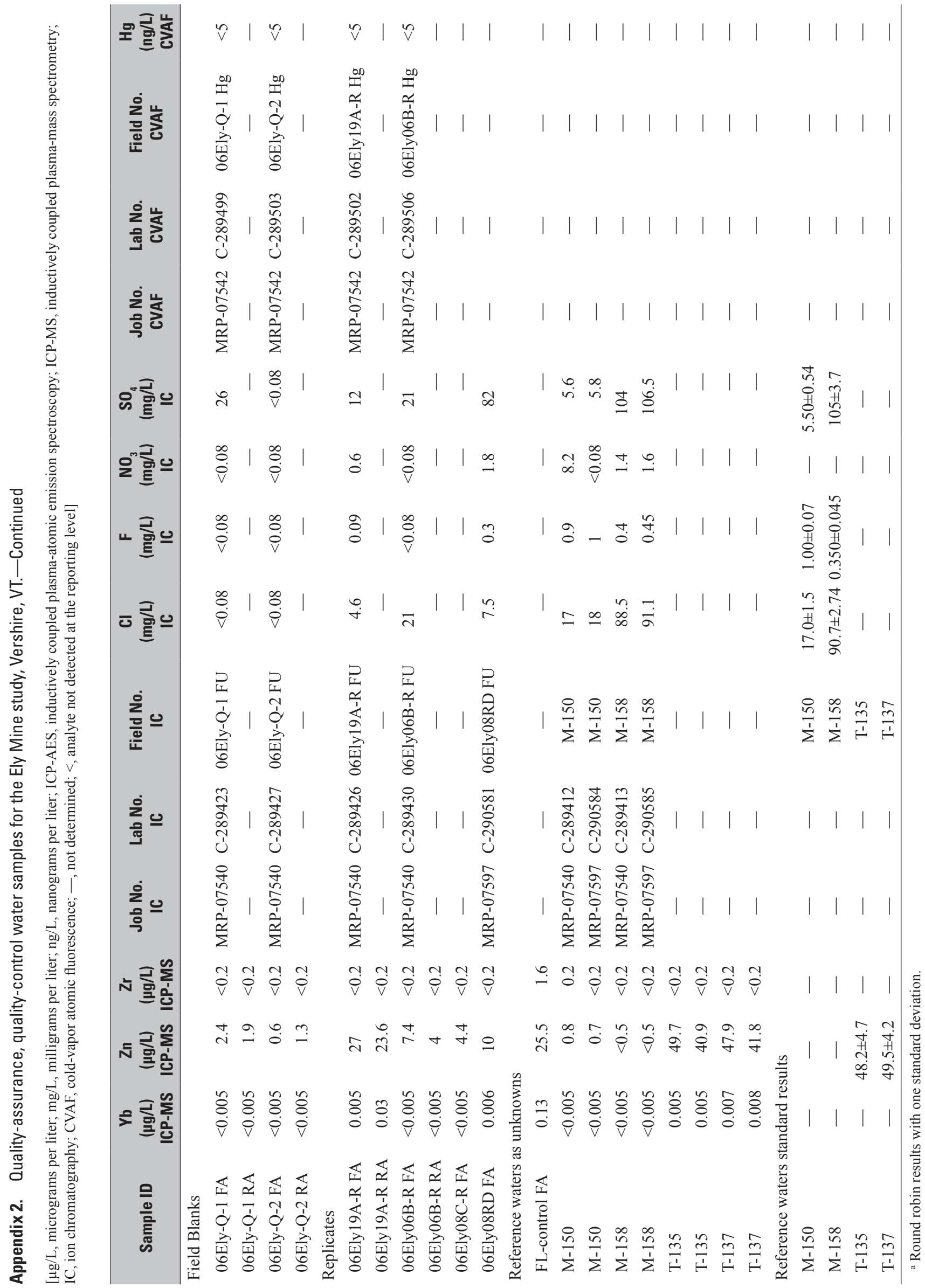





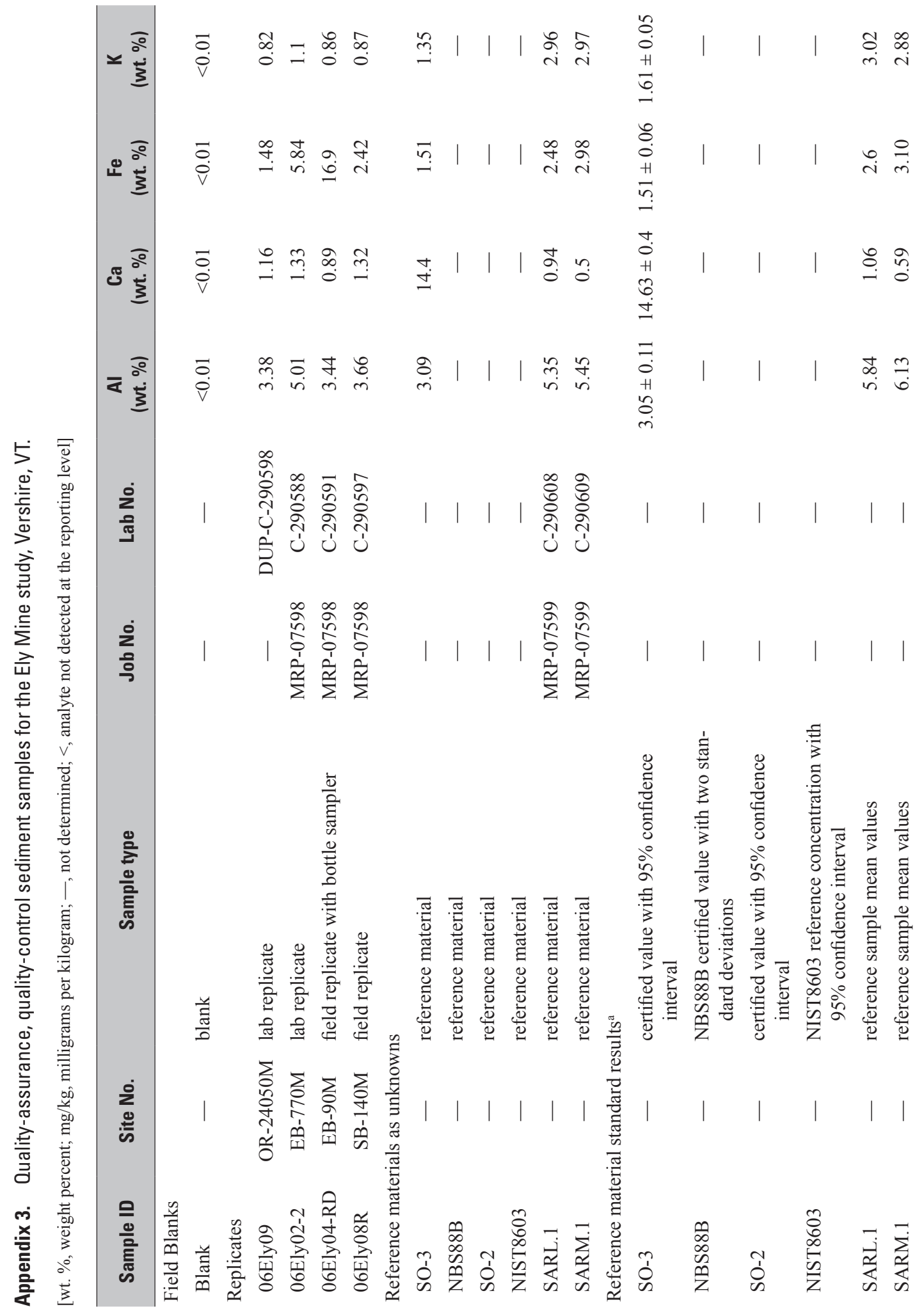




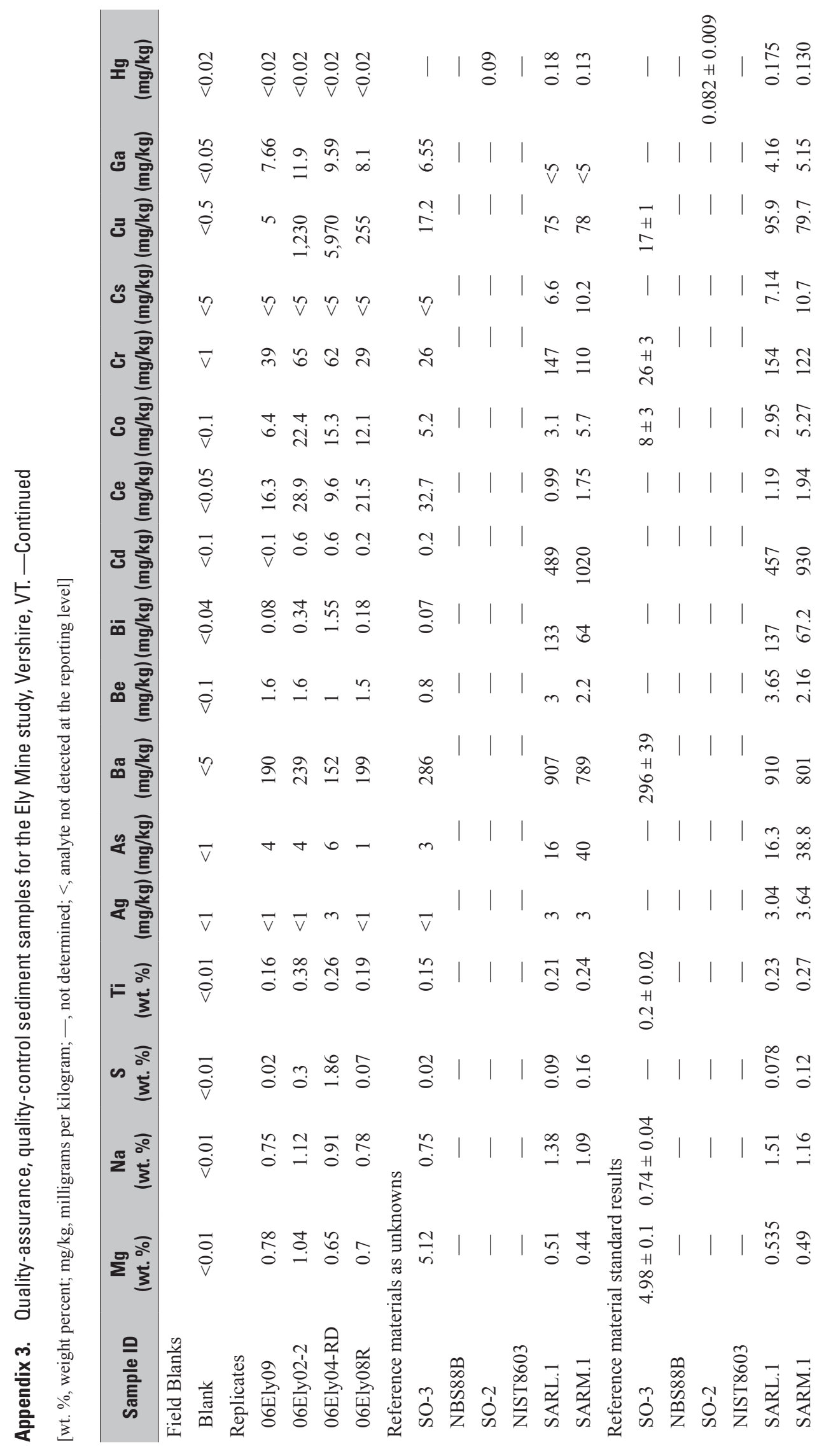




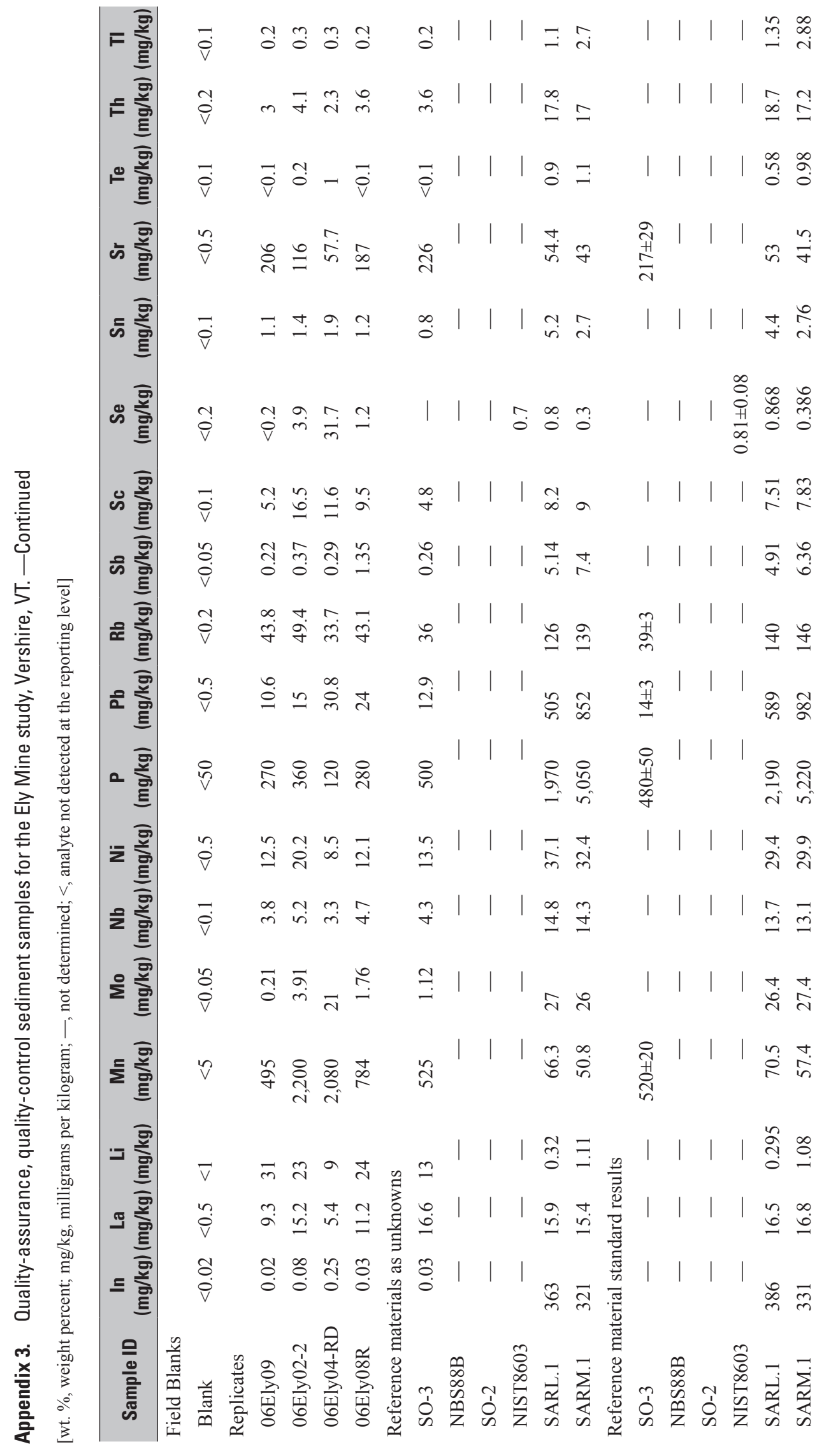




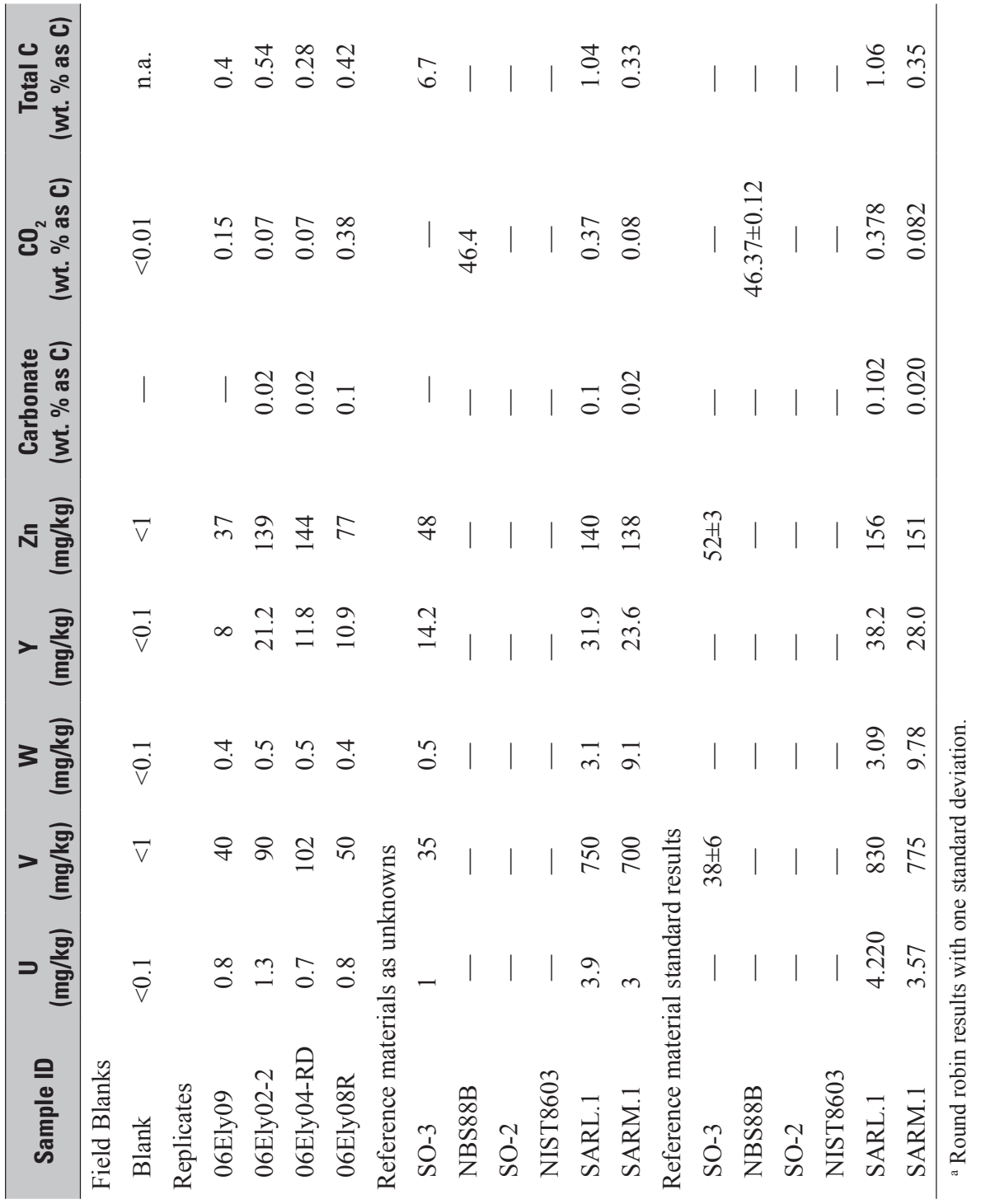




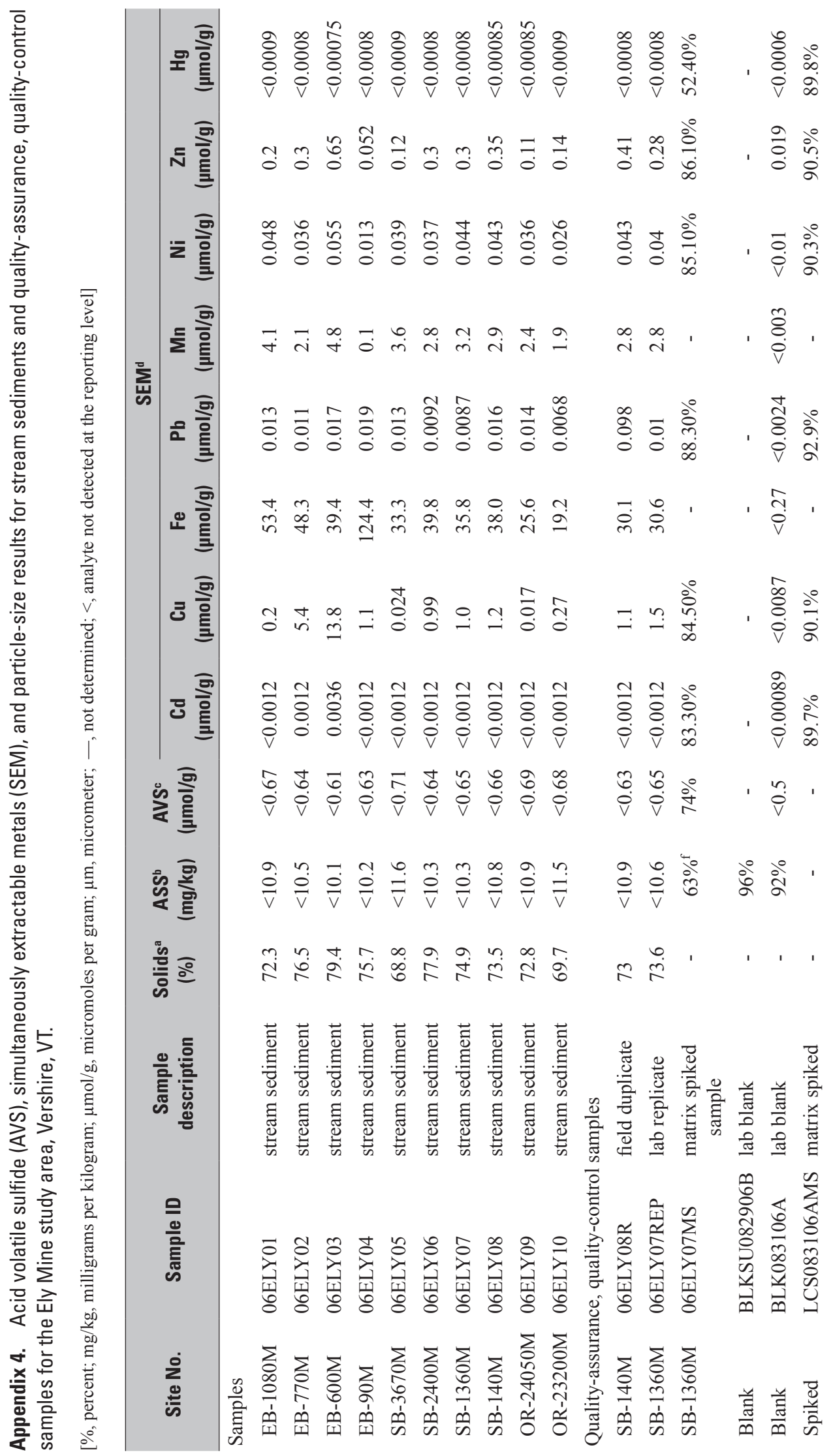


|

亞向 | | | | | | | | | |

mृำ

틀

กุ ำ

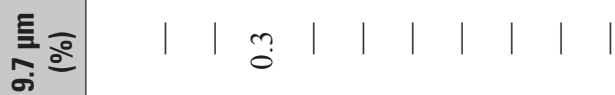

恶。

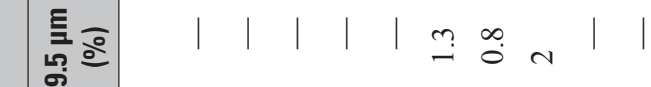

흘 恶

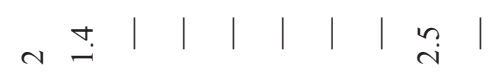

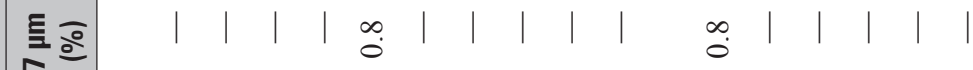

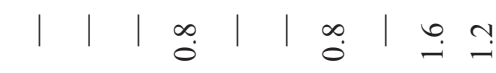

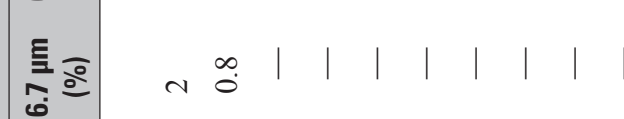

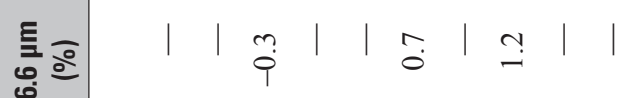

高市

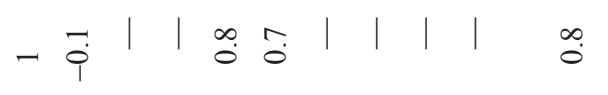

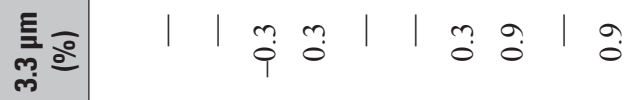

至方

悹

$0000000000 \frac{\sum^{\frac{\pi}{1}} 00}{0}$

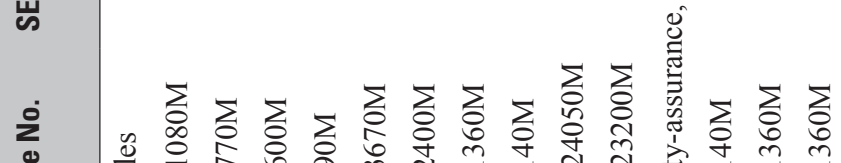

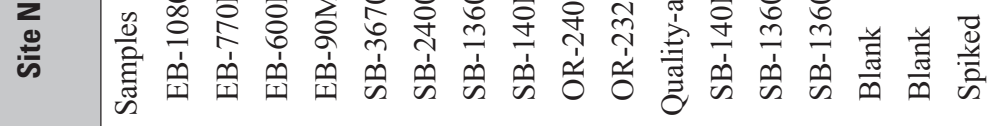




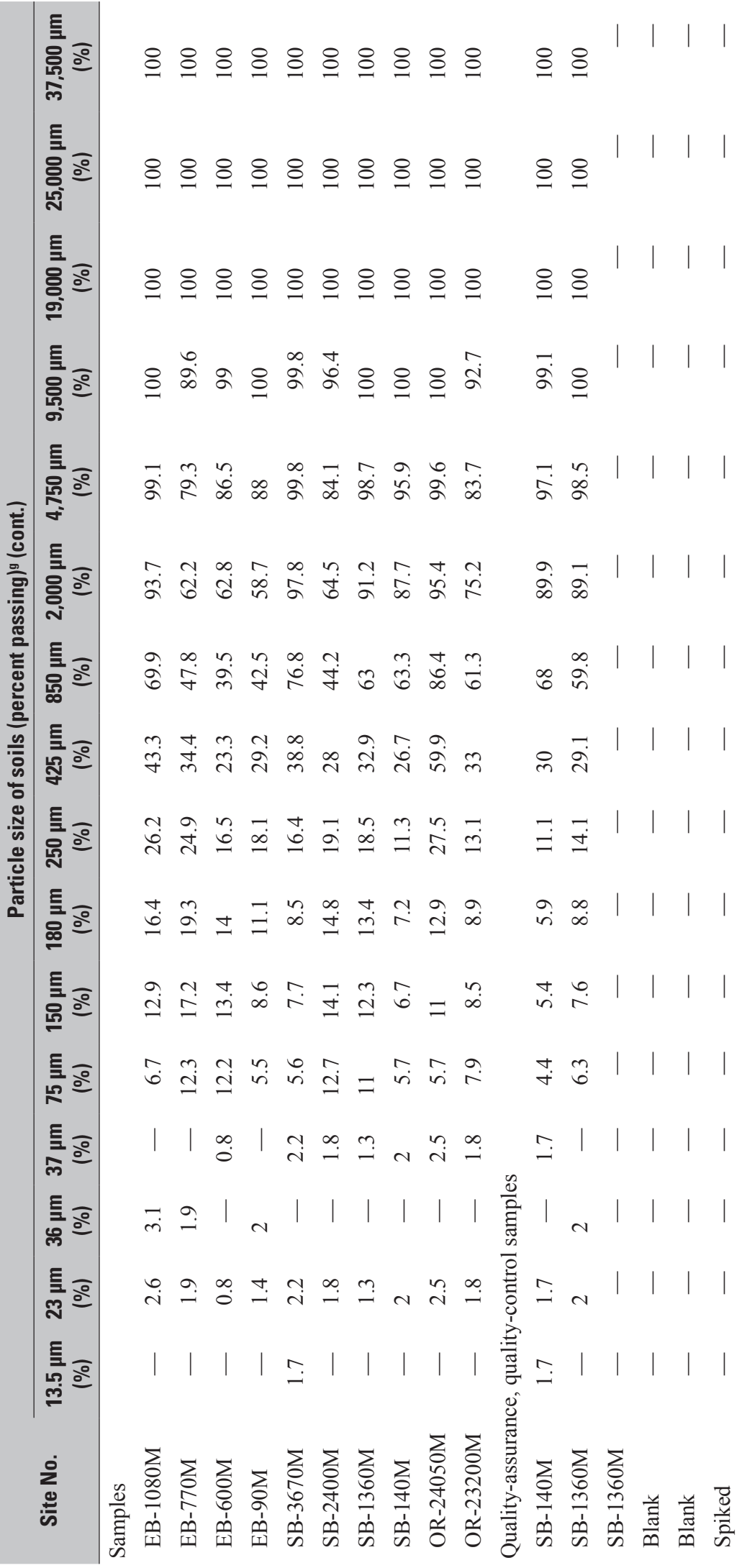




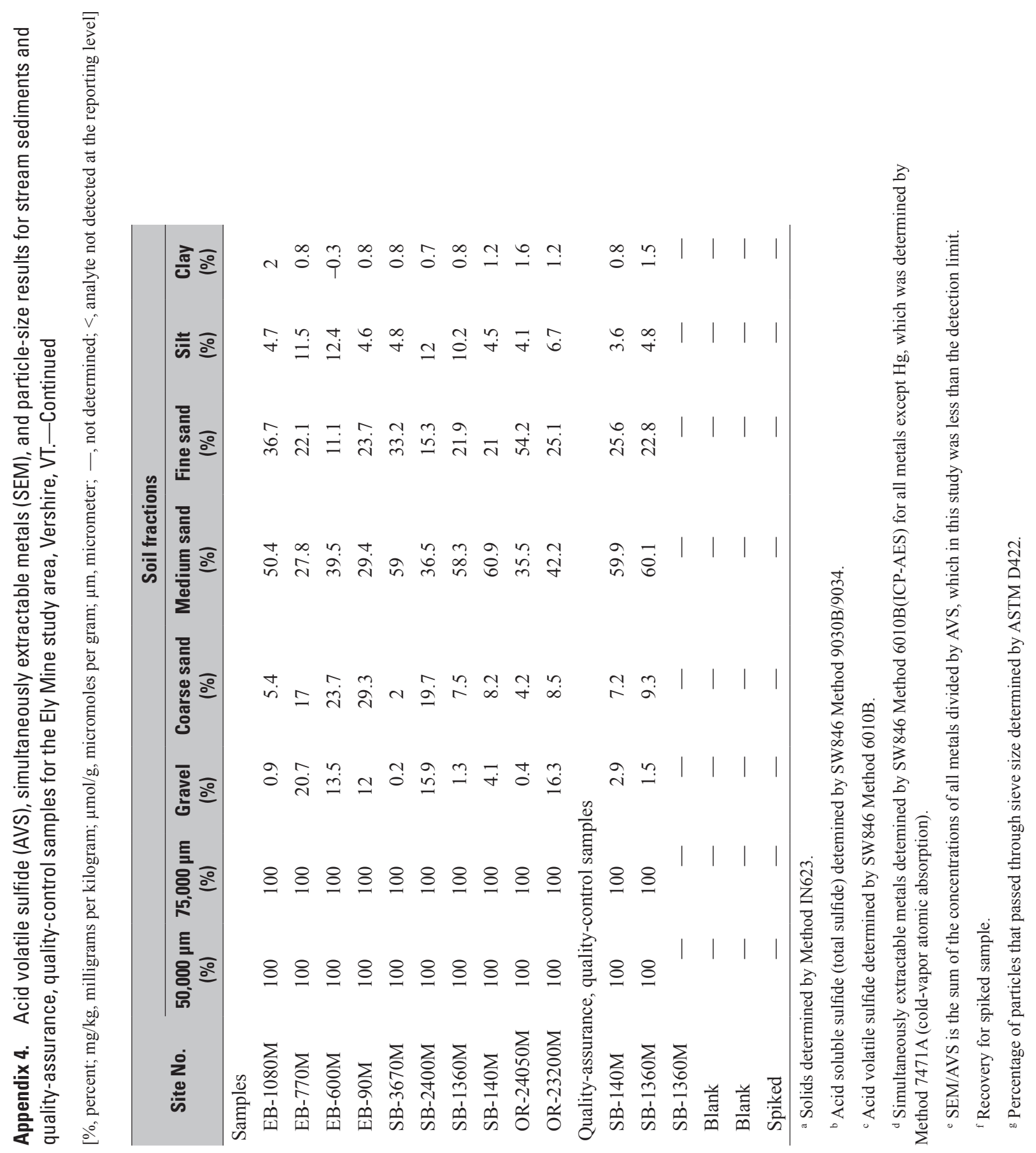


Appendix 5. Summary of select constituents in surface waters relative to ambient water-quality criteria (AWOC) for stream reaches in the Ely Mine study area, Vershire, VT, 2000 to 2007.

[Values in italics are estimated; chronic, average allowable concentration; >, greater than; <, less than; \%, percent; SE, standard error; UCL, upper confidence level; Q3, 75th percentile; Q1, 25th percentile; mg/L, micrograms per liter]

\begin{tabular}{|c|c|c|c|c|c|c|c|c|c|c|c|c|}
\hline \multirow{3}{*}{ Element } & \multirow{3}{*}{$\begin{array}{c}\text { AWQC } \\
\text { chronic } \\
\text { ( } \mu \mathrm{g} / \mathrm{L})\end{array}$} & \multicolumn{11}{|c|}{ Ely Brook from river meter 0 to 350} \\
\hline & & \multirow[b]{2}{*}{ Samples } & \multirow[b]{2}{*}{ Detects } & \multirow{2}{*}{$\begin{array}{l}\text { Detects } \\
>\text { AWOC }\end{array}$} & \multirow{2}{*}{$\begin{array}{l}\text { Samples } \\
\text { used in } \\
\text { analysis }\end{array}$} & \multirow[b]{2}{*}{$\begin{array}{l}\text { Maximum } \\
(\mu \mathrm{g} / \mathrm{L})\end{array}$} & \multicolumn{3}{|c|}{ Mean } & \multirow[b]{2}{*}{$\begin{array}{c}03 \\
(\mu \mathrm{g} / \mathrm{L})\end{array}$} & \multirow{2}{*}{$\begin{array}{c}\text { Median } \\
\text { ( } \mu \mathrm{g} / \mathrm{L})\end{array}$} & \multirow[b]{2}{*}{$\begin{array}{c}01 \\
(\mu g / L)\end{array}$} \\
\hline & & & & & & & $\begin{array}{l}\text { Value } \\
\text { ( } \mu \mathrm{g} / \mathrm{L})\end{array}$ & $\underset{(\mu g / L)}{S E}$ & $\begin{array}{c}95 \% \text { UCL } \\
(\mu \mathrm{g} / \mathrm{L})\end{array}$ & & & \\
\hline Aluminum $^{\mathrm{a}}$ & 87 & 16 & 16 & 15 & 16 & 7,900 & 3,830 & 491 & 4,690 & 5,100 & 4,000 & 2,750 \\
\hline Antimony ${ }^{\mathrm{b}}$ & 104 & 14 & 6 & 0 & 10 & 0.13 & 0.04 & 0.01 & 0.07 & 0.06 & 0.03 & 0.02 \\
\hline Arsenic ${ }^{c}$ & 190 & 14 & 3 & 0 & 11 & .51 & .15 & .04 & .22 & .14 & .08 & .08 \\
\hline Barium $^{\mathrm{b}}$ & 3.8 & 14 & 14 & 14 & 14 & 40 & 19 & 2.1 & 23 & 23 & 16 & 13 \\
\hline Beryllium $^{b}$ & 5.09 & 14 & 11 & 0 & 14 & .50 & .18 & .03 & .23 & .23 & .16 & .09 \\
\hline Cadmium $^{\mathrm{c}, \mathrm{d}}$ & 1.1 & 14 & 14 & 12 & 14 & 4.70 & 2.27 & .37 & 2.92 & 3.23 & 2.25 & 1.28 \\
\hline Chromium $^{\mathrm{c}}$ & 11 & 15 & 12 & 0 & 15 & 5.0 & 1.9 & .3 & 2.5 & 2.4 & 1.4 & 1.0 \\
\hline Cobalt $^{\mathrm{b}}$ & 3.06 & 15 & 15 & 14 & 15 & 170 & 66.4 & 11.5 & 86.6 & 86.0 & 63.0 & 36.9 \\
\hline Copper ${ }^{\mathrm{c}, \mathrm{d}}$ & 11.8 & 15 & 15 & 14 & 15 & 3,400 & 1,580 & 218 & 1,960 & 1,900 & 1,560 & 1,270 \\
\hline Iron $^{c}$ & 1,000 & 11 & 10 & 9 & 11 & 13,000 & 5,990 & 1,380 & 8,500 & 11,900 & 5,600 & 2,180 \\
\hline Lead $^{\mathrm{c}, \mathrm{d}}$ & 3.2 & 15 & 9 & 0 & 13 & .95 & .38 & .08 & .52 & .51 & .28 & .22 \\
\hline Manganese ${ }^{b}$ & 80.3 & 15 & 15 & 13 & 15 & 1,100 & 362 & 66 & 479 & 460 & 320 & 223 \\
\hline Mercury $^{\mathrm{a}}$ & .012 & 8 & 1 & 1 & 3 & .01 & & & & & & \\
\hline Nickel ${ }^{\mathrm{c}, \mathrm{d}}$ & 158 & 15 & 15 & 0 & 15 & 36 & 17 & 2.4 & 21 & 23 & 17 & 11 \\
\hline Selenium $^{\mathrm{c}}$ & 5 & 15 & 8 & 0 & 12 & .8 & .5 & .1 & .6 & .7 & .5 & .3 \\
\hline Silver ${ }^{\mathrm{b}}$ & .36 & 15 & 4 & 1 & 11 & .40 & .04 & .04 & .10 & .01 & $<.01$ & $<.01$ \\
\hline Strontium $^{\mathrm{b}}$ & 620 & 13 & 13 & 0 & 13 & 120 & 63 & 8 & 78 & 80 & 60 & 40 \\
\hline Thallium $^{\mathrm{b}}$ & 18 & 15 & 4 & 0 & 12 & .06 & .04 & .003 & .04 & .05 & .04 & .03 \\
\hline Uranium $^{\mathrm{b}}$ & 1.87 & 9 & 9 & 0 & 9 & .68 & .37 & .07 & .51 & .53 & .41 & .18 \\
\hline Vanadium $^{\mathrm{b}}$ & 19.1 & 15 & 5 & 0 & 12 & .20 & .10 & .01 & .12 & .11 & .09 & .08 \\
\hline Zinc $^{\mathrm{c}, \mathrm{d}}$ & 106 & 15 & 15 & 13 & 15 & 590 & 290 & 40 & 360 & 391 & 300 & 182 \\
\hline
\end{tabular}


Appendix 5. Summary of select constituents in surface waters relative to ambient water-quality criteria (AWOC) for stream reaches in the Ely Mine study area, Vershire, VT, 2000 to 2007.-Continued

[Values in italics are estimated; chronic, average allowable concentration; >, greater than; <, less than; \%, percent; SE, standard error; UCL, upper confidence level; Q3, 75th percentile; Q1, 25th percentile; mg/L, micrograms per liter]

\begin{tabular}{|c|c|c|c|c|c|c|c|c|c|c|c|c|}
\hline \multirow{3}{*}{ Element } & \multirow{3}{*}{$\begin{array}{c}\text { AWQC } \\
\text { chronic } \\
\text { ( } \mu \mathrm{g} / \mathrm{L})\end{array}$} & \multicolumn{11}{|c|}{ Ely Brook from river meter 350 to 540} \\
\hline & & \multirow[b]{2}{*}{ Samples } & \multirow[b]{2}{*}{ Detects } & \multirow{2}{*}{$\begin{array}{l}\text { Detects } \\
\text { >AWQC }\end{array}$} & \multirow{2}{*}{$\begin{array}{l}\text { Samples } \\
\text { used in } \\
\text { analysis }\end{array}$} & \multirow{2}{*}{$\begin{array}{l}\text { Maximum } \\
(\mu \mathrm{g} / \mathrm{L})\end{array}$} & \multicolumn{3}{|c|}{ Mean } & \multirow{2}{*}{$\begin{array}{c}03 \\
(\mu \mathrm{g} / \mathrm{L})\end{array}$} & \multirow{2}{*}{$\begin{array}{c}\text { Median } \\
(\mu \mathrm{g} / \mathrm{L})\end{array}$} & \multirow{2}{*}{$\begin{array}{c}01 \\
(\mu \mathrm{g} / \mathrm{L})\end{array}$} \\
\hline & & & & & & & $\begin{array}{l}\text { Value } \\
\text { ( } \mu \mathrm{g} / \mathrm{L})\end{array}$ & $\begin{array}{c}\text { SE } \\
(\mu \mathrm{g} / \mathrm{L})\end{array}$ & $\begin{array}{c}95 \% \text { UCL } \\
\text { ( } \mathrm{gg} / \mathrm{L})\end{array}$ & & & \\
\hline Aluminum & 87 & 13 & 13 & 13 & 13 & 34,000 & 9,010 & 2,790 & 14,000 & 8,700 & 5,000 & 3,750 \\
\hline Antimony & 104 & 12 & 3 & 0 & 9 & 0.28 & 0.07 & 0.03 & 0.12 & 0.11 & 0.03 & 0.01 \\
\hline Arsenic & 190 & 12 & 2 & 0 & 12 & 1.9 & .22 & .16 & .50 & .08 & .02 & .01 \\
\hline Barium & 3.8 & 12 & 12 & 12 & 12 & 26 & 17 & 1.4 & 19 & 21 & 16 & 13 \\
\hline Beryllium & 5.09 & 12 & 12 & 0 & 12 & 1.80 & .47 & .15 & .74 & .54 & .25 & .16 \\
\hline Cadmium & 1.1 & 12 & 12 & 12 & 12 & 14 & 4.48 & 1.27 & 6.76 & 5.15 & 3.10 & 1.60 \\
\hline Chromium & 11 & 12 & 12 & 2 & 12 & 32 & 7.6 & 3.3 & 14 & 7.5 & 2.8 & 2.0 \\
\hline Cobalt & 3.06 & 12 & 12 & 12 & 12 & 630 & 167 & 61.1 & 276 & 195 & 80.5 & 44.9 \\
\hline Copper & 11.8 & 12 & 12 & 12 & 12 & 6,500 & 2,420 & 485 & 3,290 & 2,520 & 2,050 & 1,300 \\
\hline Iron & 1,000 & 8 & 8 & 8 & 8 & 74,600 & 31,300 & 10,300 & 50,700 & 62,200 & 17,600 & 7,180 \\
\hline Lead & 3.2 & 12 & 10 & 0 & 12 & 1.40 & .44 & .11 & .65 & .46 & .33 & .18 \\
\hline Manganese & 80.3 & 12 & 12 & 12 & 12 & 3,100 & 911 & 302 & 1,450 & 1,180 & 489 & 295 \\
\hline Mercury & .012 & 7 & 0 & & & & & & & & & \\
\hline Nickel & 158 & 12 & 12 & 0 & 12 & 140 & 41 & 14 & 66 & 43 & 20 & 16 \\
\hline Selenium & 5 & 12 & 8 & 0 & 12 & 1.0 & .4 & .1 & .6 & .6 & .4 & .2 \\
\hline Silver & .36 & 10 & 3 & 2 & 10 & .15 & .03 & .01 & .05 & .03 & .01 & $<.01$ \\
\hline Strontium & 620 & 12 & 12 & 0 & 12 & 170 & 73 & 14 & 98 & 78 & 64 & 39 \\
\hline Thallium & 18 & 12 & 4 & 0 & 12 & .11 & .05 & .01 & .07 & .09 & .04 & .03 \\
\hline Uranium & 1.87 & 7 & 7 & 2 & 7 & 4.00 & 1.44 & .56 & 2.52 & 3.10 & .58 & .49 \\
\hline Vanadium & 19.1 & 12 & 9 & 0 & 9 & 3.00 & .61 & .32 & 1.19 & .41 & .10 & .07 \\
\hline Zinc & 106 & 12 & 12 & 12 & 12 & 2,300 & 702 & 207 & 1,070 & 740 & 385 & 311 \\
\hline
\end{tabular}


Appendix 5. Summary of select constituents in surface waters relative to ambient water-quality criteria (AWOC) for stream reaches in the Ely Mine study area, Vershire, VT, 2000 to 2007.-Continued

[Values in italics are estimated; chronic, average allowable concentration; >, greater than; <, less than; \%, percent; SE, standard error; UCL, upper confidence level; Q3, 75th percentile; Q1, 25th percentile; mg/L, micrograms per liter]

\begin{tabular}{|c|c|c|c|c|c|c|c|c|c|c|c|c|}
\hline \multirow{3}{*}{ Element } & \multirow{3}{*}{$\begin{array}{c}\text { AWOC } \\
\text { chronic } \\
(\mu \mathrm{g} / \mathrm{L})\end{array}$} & \multicolumn{11}{|c|}{ Ely Brook from river meter 540 to 800} \\
\hline & & \multirow[b]{2}{*}{ Samples } & \multirow[b]{2}{*}{ Detects } & \multirow[b]{2}{*}{$\begin{array}{l}\text { Detects } \\
\text { >AWQC }\end{array}$} & \multirow{2}{*}{$\begin{array}{l}\text { Samples } \\
\text { used in } \\
\text { analysis }\end{array}$} & \multirow[b]{2}{*}{$\begin{array}{c}\text { Maximum } \\
(\mu \mathrm{g} / \mathrm{L})\end{array}$} & \multicolumn{3}{|c|}{ Mean } & \multirow{2}{*}{$\begin{array}{c}03 \\
(\mu \mathrm{g} / \mathrm{L})\end{array}$} & \multirow{2}{*}{$\begin{array}{l}\text { Median } \\
\text { ( } \mu \mathrm{g} / \mathrm{L})\end{array}$} & \multirow[b]{2}{*}{$\begin{array}{c}01 \\
(\mu \mathrm{g} / \mathrm{L})\end{array}$} \\
\hline & & & & & & & $\begin{array}{l}\text { Value } \\
(\mu \mathrm{g} / \mathrm{L})\end{array}$ & $\begin{array}{c}\text { SE } \\
(\mu \mathrm{g} / \mathrm{L})\end{array}$ & $\begin{array}{c}95 \% \text { UCL } \\
(\mu \mathrm{g} / \mathrm{L})\end{array}$ & & & \\
\hline Aluminum & 87 & 6 & 6 & 5 & 6 & 17,900 & 3,380 & 2,910 & 9,250 & 5,460 & 445 & 140 \\
\hline Antimony & 104 & 5 & 0 & & & & & & & & & \\
\hline Arsenic & 190 & 5 & 0 & & & & & & & & & \\
\hline Barium & 3.8 & 5 & 5 & 5 & 5 & 20 & 16 & 1.3 & 19 & 19 & 16 & 13 \\
\hline Beryllium & 5.09 & 5 & 2 & 0 & 2 & .06 & & & & & & \\
\hline Cadmium & 1.1 & 5 & 5 & 0 & 5 & .95 & .47 & .14 & .75 & .73 & .45 & .21 \\
\hline Chromium & 11 & 5 & 3 & 0 & 3 & .10 & & & & & & \\
\hline Cobalt & 3.06 & 5 & 5 & 5 & 5 & 31.1 & 13.3 & 4.64 & 23.1 & 22.0 & 10.0 & 6.20 \\
\hline Copper & 11.8 & 5 & 5 & 5 & 5 & 837 & 344 & 131 & 625 & 611 & 218 & 142 \\
\hline Iron & 1,000 & 2 & 1 & 0 & 2 & 52 & & & & & & \\
\hline Lead & 3.2 & 5 & 2 & 0 & 2 & .1 & & & & & & \\
\hline Manganese & 80.3 & 5 & 5 & 2 & 5 & 217 & 96.3 & 31.7 & 164 & 155 & 78.0 & 46.2 \\
\hline Mercury & .012 & 5 & 0 & & & & & & & & & \\
\hline Nickel & 158 & 5 & 5 & 0 & 5 & 12 & 6.0 & 1.7 & 9.5 & 9.2 & 5.6 & 3.0 \\
\hline Selenium & 5 & 5 & 1 & & 1 & .2 & & & & & & \\
\hline Silver & .36 & 5 & 0 & & & & & & & & & \\
\hline Strontium & 620 & 5 & 5 & 0 & 5 & 62 & 45 & 6 & 58 & 57 & 50 & 30 \\
\hline Thallium & 18 & 5 & 0 & & & & & & & & & \\
\hline Uranium & 1.87 & 2 & 1 & & 2 & .11 & & & & & & \\
\hline Vanadium & 19.1 & 5 & 3 & 0 & 3 & .10 & & & & & & \\
\hline Zinc & 106 & 5 & 5 & 1 & 5 & 114 & 56 & 15 & 88 & 84 & 47 & 31 \\
\hline
\end{tabular}


Appendix 5. Summary of select constituents in surface waters relative to ambient water-quality criteria (AWQC) for stream reaches in the Ely Mine study area, Vershire, VT, 2000 to 2007.-Continued

[Values in italics are estimated; chronic, average allowable concentration; >, greater than; <, less than; \%, percent; SE, standard error; UCL, upper confidence level; Q3, 75th percentile; Q1, 25th percentile; mg/L, micrograms per liter]

\begin{tabular}{|c|c|c|c|c|c|c|c|c|c|c|c|c|}
\hline \multirow{3}{*}{ Element } & \multirow{3}{*}{$\begin{array}{c}\text { AWOC } \\
\text { chronic } \\
(\mu \mathrm{g} / \mathrm{L})\end{array}$} & \multicolumn{11}{|c|}{ Ely Brook above river meter 800} \\
\hline & & \multirow[b]{2}{*}{ Samples } & \multirow[b]{2}{*}{ Detects } & \multirow[b]{2}{*}{$\begin{array}{l}\text { Detects } \\
\text { >AWOC }\end{array}$} & \multirow{2}{*}{$\begin{array}{c}\text { Samples } \\
\text { used in } \\
\text { analysis }\end{array}$} & \multirow[b]{2}{*}{$\begin{array}{l}\text { Maximum- } \\
(\mu \mathrm{g} / \mathrm{L})\end{array}$} & \multicolumn{3}{|c|}{ Mean } & \multirow{2}{*}{$\begin{array}{c}03 \\
(\mu \mathrm{g} / \mathrm{L})\end{array}$} & \multirow{2}{*}{$\begin{array}{c}\text { Median } \\
\text { ( } \mu \mathrm{g} / \mathrm{L})\end{array}$} & \multirow[b]{2}{*}{$\begin{array}{c}01 \\
(\mu \mathrm{g} / \mathrm{L})\end{array}$} \\
\hline & & & & & & & $\begin{array}{l}\text { Value } \\
(\mu g / L)\end{array}$ & $\begin{array}{c}\text { SE } \\
(\mu \mathrm{g} / \mathrm{L})\end{array}$ & $\begin{array}{c}95 \% \text { UCL } \\
\text { ( } \mu \mathrm{g} / \mathrm{L})\end{array}$ & & & \\
\hline Aluminum & 87 & 10 & 10 & 4 & 10 & 240 & 81 & 25 & 126 & 135 & 48 & 15 \\
\hline Antimony & 104 & 10 & 3 & 0 & 7 & 0.31 & 0.06 & 0.04 & 0.15 & 0.05 & 0.01 & $<0.01$ \\
\hline Arsenic & 190 & 10 & 2 & 0 & 8 & .40 & .12 & .04 & .20 & .16 & .08 & .04 \\
\hline Barium & 3.8 & 10 & 10 & 10 & 10 & 30 & 19 & 1.6 & 22 & 22 & 18 & 15 \\
\hline Beryllium & 5.09 & 10 & 0 & & & & & & & & & \\
\hline Cadmium & 1.1 & 10 & 0 & & & & & & & & & \\
\hline Chromium & 11 & 10 & 4 & 0 & 4 & .2 & & & & & & \\
\hline Cobalt & 3.06 & 10 & 4 & 0 & 10 & .14 & .05 & .01 & .08 & .09 & .03 & .02 \\
\hline Copper & 11.8 & 10 & 8 & 0 & 10 & 6.9 & 1.9 & .6 & 3.0 & 1.9 & 1.4 & 1.1 \\
\hline Iron & 1,000 & 6 & 1 & 0 & 6 & 22 & & & & & & \\
\hline Lead & 3.2 & 10 & 3 & 0 & 8 & .09 & .04 & .009 & .05 & .05 & .03 & .02 \\
\hline Manganese & 80.3 & 10 & 10 & 2 & 10 & 124 & 22.4 & 14.3 & 48.5 & 24 & 1.75 & .76 \\
\hline Mercury & .012 & 5 & 0 & & & & & & & & & \\
\hline Nickel & 158 & 10 & 8 & 0 & 10 & .7 & .3 & .1 & .4 & .5 & .4 & .1 \\
\hline Selenium & 5 & 10 & 0 & & & & & & & & & \\
\hline Silver & .36 & 10 & 2 & 0 & 6 & .03 & .01 & .004 & .02 & .02 & $<.01$ & $<.01$ \\
\hline Strontium & 620 & 10 & 10 & 0 & 10 & 48 & 32 & 3 & 38 & 41 & 30 & 22 \\
\hline Thallium & 18 & 10 & 0 & & & & & & & & & \\
\hline Uranium & 1.87 & 6 & 5 & 0 & 5 & .01 & .01 & .0005 & .01 & .01 & .01 & .01 \\
\hline Vanadium & 19.1 & 10 & 4 & 0 & 9 & .2 & .11 & .01 & .14 & .14 & .10 & .09 \\
\hline Zinc & 106 & 10 & 10 & 0 & 10 & 33 & 12 & 3 & 18 & 22 & 8 & 3 \\
\hline
\end{tabular}


Appendix 5. Summary of select constituents in surface waters relative to ambient water-quality criteria (AWOC) for stream reaches in the Ely Mine study area, Vershire, VT, 2000 to 2007.-Continued

[Values in italics are estimated; chronic, average allowable concentration; >, greater than; <, less than; \%, percent; SE, standard error; UCL, upper confidence level; Q3, 75th percentile; Q1, 25th percentile; mg/L, micrograms per liter]

\begin{tabular}{|c|c|c|c|c|c|c|c|c|c|c|c|c|}
\hline \multirow{3}{*}{ Element } & \multirow{3}{*}{$\begin{array}{c}\text { AWOC } \\
\text { chronic } \\
\text { ( } \mu \mathrm{g} / \mathrm{L})\end{array}$} & \multicolumn{11}{|c|}{ Ely Brook Tributary 1} \\
\hline & & \multirow[b]{2}{*}{ Samples } & \multirow[b]{2}{*}{ Detects } & \multirow{2}{*}{$\begin{array}{l}\text { Detects } \\
\text { >AWQC }\end{array}$} & \multirow{2}{*}{$\begin{array}{l}\text { Samples } \\
\text { used in } \\
\text { analysis }\end{array}$} & \multirow[b]{2}{*}{$\begin{array}{c}\text { Maximum } \\
(\mu \mathrm{g} / \mathrm{L})\end{array}$} & \multicolumn{3}{|c|}{ Mean } & \multirow[b]{2}{*}{$\begin{array}{c}03 \\
(\mu \mathrm{g} / \mathrm{L})\end{array}$} & \multirow{2}{*}{$\begin{array}{c}\text { Median } \\
\text { ( } \mu \mathrm{g} / \mathrm{L})\end{array}$} & \multirow{2}{*}{$\begin{array}{c}01 \\
\text { ( } \mu \mathrm{g} / \mathrm{L})\end{array}$} \\
\hline & & & & & & & $\begin{array}{l}\text { Value } \\
(\mu \mathrm{g} / \mathrm{L})\end{array}$ & $\begin{array}{c}\text { SE } \\
(\mu g / L)\end{array}$ & $\begin{array}{c}95 \% \text { UCL } \\
(\mu \mathrm{g} / \mathrm{L})\end{array}$ & & & \\
\hline Aluminum & 87 & 6 & 6 & 2 & 6 & 3,300 & 597 & 541 & 1,990 & 892 & 62 & 39 \\
\hline Antimony & 104 & 6 & 0 & & & & & & & & & \\
\hline Barium & 3.8 & 6 & 6 & 6 & 6 & 31 & 16 & 3.2 & 23 & 23 & 14 & 10 \\
\hline Beryllium & 5.09 & 6 & 1 & 0 & & .2 & & & & & & \\
\hline Cadmium & 1.1 & 6 & 4 & 1 & 4 & 1.90 & .35 & .31 & .98 & & & \\
\hline Chromium & 11 & 6 & 4 & 0 & 4 & .5 & .3 & .1 & .5 & & & \\
\hline Cobalt & 3.06 & 6 & 6 & 1 & 6 & 32.7 & 5.59 & 5.42 & 16.5 & 8.44 & .18 & .06 \\
\hline Manganese & 80.3 & 6 & 6 & 1 & 6 & 224 & 39.3 & 37.1 & 114 & 60.3 & 2.2 & .7 \\
\hline Mercury & .012 & 5 & 0 & & & & & & & & & \\
\hline Nickel & 158 & 6 & 6 & 0 & 6 & 12.1 & 2.5 & 1.9 & 6.4 & 3.7 & .7 & .3 \\
\hline Selenium & 5 & 6 & 2 & 0 & 3 & .4 & & & & & & \\
\hline Silver & .36 & 6 & 0 & & & & & & & & & \\
\hline Strontium & 620 & 6 & 6 & 0 & 6 & 40 & 24 & 4 & 31 & 32 & 20 & 16 \\
\hline Thallium & 18 & 6 & 0 & & & & & & & & & \\
\hline Uranium & 1.87 & 2 & 2 & 0 & 2 & .03 & & & & & & \\
\hline
\end{tabular}


Appendix 5. Summary of select constituents in surface waters relative to ambient water-quality criteria (AWQC) for stream reaches in the Ely Mine study area, Vershire, VT, 2000 to 2007.-Continued

[Values in italics are estimated; chronic, average allowable concentration; >, greater than; <, less than; \%, percent; SE, standard error; UCL, upper confidence level; Q3, 75th percentile; Q1, 25th percentile; mg/L, micrograms per liter]

\begin{tabular}{|c|c|c|c|c|c|c|c|c|c|c|c|c|}
\hline \multirow{3}{*}{ Element } & \multirow{3}{*}{$\begin{array}{c}\text { AWOC } \\
\text { chronic } \\
\text { ( } \mu \mathrm{g} / \mathrm{L})\end{array}$} & \multicolumn{11}{|c|}{ Ely Brook Tributary 2 from river meter 0 to 340} \\
\hline & & \multirow[b]{2}{*}{ Samples } & \multirow[b]{2}{*}{ Detects } & \multirow{2}{*}{$\begin{array}{l}\text { Detects } \\
\text { >AWQC }\end{array}$} & \multirow{2}{*}{$\begin{array}{c}\text { Samples } \\
\text { used in } \\
\text { analysis }\end{array}$} & \multirow[b]{2}{*}{$\begin{array}{l}\text { Maximum } \\
(\mu \mathrm{g} / \mathrm{L})\end{array}$} & \multicolumn{3}{|c|}{ Mean } & \multirow{2}{*}{$\begin{array}{c}03 \\
(\mu \mathrm{g} / \mathrm{L})\end{array}$} & \multirow{2}{*}{$\begin{array}{c}\text { Median } \\
(\mu \mathrm{g} / \mathrm{L})\end{array}$} & \multirow{2}{*}{$\begin{array}{c}01 \\
(\mu \mathrm{g} / \mathrm{L})\end{array}$} \\
\hline & & & & & & & $\begin{array}{l}\text { Value } \\
\text { ( } \mu \mathrm{g} / \mathrm{L})\end{array}$ & $\begin{array}{c}\text { SE } \\
(\mu \mathrm{g} / \mathrm{L})\end{array}$ & $\begin{array}{c}95 \% \text { UCL } \\
(\mu \mathrm{g} / \mathrm{L})\end{array}$ & & & \\
\hline Aluminum & 87 & 29 & 29 & 24 & 29 & 30,000 & 5,560 & 1,430 & 7,990 & 6,900 & 2,300 & 1,010 \\
\hline Antimony & 104 & 36 & 7 & 0 & 27 & 3.10 & .18 & .11 & .37 & .07 & .01 & $<.01$ \\
\hline Arsenic & 190 & 36 & 2 & 0 & 2 & .09 & & & & & & \\
\hline Barium & 3.8 & 36 & 27 & 27 & 27 & 43 & 18 & 1.8 & 21 & 19 & 17 & 11 \\
\hline Beryllium & 5.09 & 37 & 19 & 0 & 28 & 1.30 & .26 & .05 & .35 & .40 & .16 & .07 \\
\hline Cadmium & 1.1 & 39 & 26 & 23 & 30 & 42.0 & 5.32 & 1.74 & 8.27 & 3.03 & 2.15 & 1.23 \\
\hline Chromium & 11 & 39 & 15 & 4 & 30 & 57 & 5.0 & 2.4 & 9.1 & 2.2 & .3 & .1 \\
\hline Cobalt & 3.06 & 39 & 30 & 24 & 30 & 1,000 & 127 & 44.6 & 202 & 66.1 & 42.0 & 19.6 \\
\hline Copper & 11.8 & 39 & 37 & 36 & 37 & 24,000 & 2,920 & 917 & 4,460 & 1,800 & 1,170 & 63.0 \\
\hline Iron & 1,000 & 19 & 16 & 9 & 19 & 197,000 & 21,600 & 11,700 & 41,900 & 14,000 & 565 & 22 \\
\hline Lead & 3.2 & 39 & 23 & 0 & 30 & 2.20 & .41 & .09 & .56 & .61 & .21 & .09 \\
\hline Manganese & 80.3 & 39 & 39 & 32 & 39 & 1,700 & 420 & 75.3 & 547 & 564 & 212 & 94.0 \\
\hline Mercury & .012 & 12 & 0 & & & & & & & & & \\
\hline Nickel & 158 & 39 & 30 & 2 & 30 & 210 & 32 & 9.3 & 48 & 27 & 13 & 7.5 \\
\hline Selenium & 5 & 39 & 14 & 0 & 29 & 4.0 & .6 & .2 & .9 & .8 & .3 & .1 \\
\hline Silver & .36 & 36 & 8 & 0 & 16 & .04 & & & & & & \\
\hline Strontium & 620 & 27 & 27 & 0 & 27 & 100 & 48 & 4.60 & 56 & 63 & 40 & 30 \\
\hline Thallium & 18 & 39 & 3 & 0 & 26 & .1 & .03 & .005 & .04 & .04 & .02 & .01 \\
\hline Uranium & 1.87 & 17 & 15 & 3 & 17 & 6.20 & 1.04 & .47 & 1.85 & .88 & .20 & .06 \\
\hline Vanadium & 19.1 & 39 & 10 & 0 & 30 & 7.80 & .49 & .28 & .96 & .21 & .04 & .01 \\
\hline Zinc & 106 & 39 & 37 & 26 & 37 & 2,800 & 440 & 110 & 625 & 390 & 240 & 53 \\
\hline
\end{tabular}


Appendix 5. Summary of select constituents in surface waters relative to ambient water-quality criteria (AWOC) for stream reaches in the Ely Mine study area, Vershire, VT, 2000 to 2007.-Continued

[Values in italics are estimated; chronic, average allowable concentration; >, greater than; <, less than; \%, percent; SE, standard error; UCL, upper confidence level; Q3, 75th percentile; Q1, 25th percentile; mg/L, micrograms per liter]

\begin{tabular}{|c|c|c|c|c|c|c|c|c|c|c|c|c|}
\hline \multirow{3}{*}{ Element } & \multirow{3}{*}{$\begin{array}{c}\text { AWOC } \\
\text { chronic } \\
(\mu \mathrm{g} / \mathrm{L})\end{array}$} & \multicolumn{11}{|c|}{ Ely Brook Tributary 2 above river meter 340} \\
\hline & & \multirow[b]{2}{*}{ Samples } & \multirow[b]{2}{*}{ Detects } & \multirow[b]{2}{*}{$\begin{array}{l}\text { Detects } \\
>\text { AWQC }\end{array}$} & \multirow{2}{*}{$\begin{array}{l}\text { Samples } \\
\text { used in } \\
\text { analysis }\end{array}$} & \multirow[b]{2}{*}{$\begin{array}{l}\text { Maximum } \\
(\mu \mathrm{g} / \mathrm{L})\end{array}$} & \multicolumn{3}{|c|}{ Mean } & \multirow{2}{*}{$\begin{array}{c}03 \\
(\mu \mathrm{g} / \mathrm{L})\end{array}$} & \multirow{2}{*}{$\begin{array}{c}\text { Median } \\
\text { ( } \mu \mathrm{g} / \mathrm{L})\end{array}$} & \multirow[b]{2}{*}{$\begin{array}{c}01 \\
(\mu \mathrm{g} / \mathrm{L})\end{array}$} \\
\hline & & & & & & & $\begin{array}{l}\text { Value } \\
\text { ( } \mu \mathrm{g} / \mathrm{L})\end{array}$ & $\begin{array}{c}\text { SE } \\
(\mu g / L)\end{array}$ & $\begin{array}{c}95 \% \text { UCL } \\
\text { ( } \mu \mathrm{g} / \mathrm{L})\end{array}$ & & & \\
\hline Aluminum & 87 & 9 & 9 & 2 & 9 & 430 & 114 & 56 & 219 & 232 & 30 & 18 \\
\hline Antimony & 104 & 15 & 4 & 0 & 9 & 1.10 & .48 & .10 & .66 & .70 & .36 & .26 \\
\hline Barium & 3.8 & 15 & 9 & 9 & 9 & 30 & 17 & 1.9 & 20 & 18 & 17 & 13 \\
\hline Beryllium & 5.09 & 15 & 0 & & & & & & & & & \\
\hline Cadmium & 1.1 & 15 & 2 & 0 & 8 & .08 & .01 & .01 & .03 & .02 & $<.01$ & $<.01$ \\
\hline Chromium & 11 & 15 & 2 & 0 & 9 & 2.0 & .4 & .2 & .8 & .5 & .2 & .1 \\
\hline Cobalt & 3.06 & 15 & 9 & 0 & 9 & .66 & .23 & .08 & .37 & .42 & .13 & .04 \\
\hline Manganese & 80.3 & 15 & 9 & 6 & 9 & 1,300 & 395 & 161 & 695 & 767 & 201 & 15.1 \\
\hline Mercury & .012 & 1 & 0 & & & & & & & & & \\
\hline Nickel & 158 & 15 & 7 & 0 & 9 & 2.7 & .7 & .3 & 1.2 & .7 & .6 & .1 \\
\hline Selenium & 5 & 15 & 1 & 0 & 5 & .5 & & & & & & \\
\hline Silver & .36 & 11 & 3 & 0 & 6 & .04 & .02 & .005 & .03 & .02 & .01 & .01 \\
\hline Strontium & 620 & 9 & 9 & 0 & 9 & 57 & 32 & 4 & 40 & 42 & 30 & 20 \\
\hline Thallium & 18 & 15 & 0 & & & & & & & & & \\
\hline Uranium & 1.87 & 8 & 4 & 0 & 5 & .01 & .01 & .001 & .01 & .01 & .01 & $<.01$ \\
\hline
\end{tabular}


Appendix 5. Summary of select constituents in surface waters relative to ambient water-quality criteria (AWQC) for stream reaches in the Ely Mine study area, Vershire, VT, 2000 to 2007.-Continued

[Values in italics are estimated; chronic, average allowable concentration; >, greater than; <, less than; \%, percent; SE, standard error; UCL, upper confidence level; Q3, 75th percentile; Q1, 25th percentile; mg/L, micrograms per liter]

\begin{tabular}{|c|c|c|c|c|c|c|c|c|c|c|c|c|}
\hline \multirow{3}{*}{ Element } & \multirow{3}{*}{$\begin{array}{c}\text { AWOC } \\
\text { chronic } \\
(\mu \mathrm{g} / \mathrm{L})\end{array}$} & \multicolumn{11}{|c|}{ Ely Brook Tributary 3} \\
\hline & & \multirow[b]{2}{*}{ Samples } & \multirow[b]{2}{*}{ Detects } & \multirow[b]{2}{*}{$\begin{array}{l}\text { Detects } \\
>\text { AWOC }\end{array}$} & \multirow{2}{*}{$\begin{array}{l}\text { Samples } \\
\text { used in } \\
\text { analysis }\end{array}$} & \multirow[b]{2}{*}{$\begin{array}{l}\text { Maximum } \\
(\mu \mathrm{g} / \mathrm{L})\end{array}$} & \multicolumn{3}{|c|}{ Mean } & \multirow{2}{*}{$\begin{array}{c}03 \\
(\mu \mathrm{g} / \mathrm{L})\end{array}$} & \multirow[b]{2}{*}{$\begin{array}{c}\text { Median } \\
\text { ( } \mu \mathrm{g} / \mathrm{L})\end{array}$} & \multirow[b]{2}{*}{$\begin{array}{c}01 \\
(\mu g / L)\end{array}$} \\
\hline & & & & & & & $\begin{array}{l}\text { Value } \\
\text { ( } \mu g / L \text { ) }\end{array}$ & $\underset{(\mu g / L)}{S E}$ & $\begin{array}{c}95 \% \text { UCL } \\
(\mu \mathrm{g} / \mathrm{L})\end{array}$ & & & \\
\hline Aluminum & 87 & 23 & 23 & 23 & 23 & 30,000 & 19,300 & 1,710 & 22,300 & 26,000 & 22,000 & 9,900 \\
\hline Antimony & 104 & 23 & 4 & 0 & 18 & .45 & .03 & .02 & .08 & .02 & $<.01$ & $<.01$ \\
\hline Arsenic & 190 & 23 & 0 & & & & & & & & & \\
\hline Barium & 3.8 & 23 & 23 & 22 & 23 & 25 & 14 & 1.3 & 16 & 20 & 12 & 10 \\
\hline Beryllium & 5.09 & 23 & 23 & 0 & 23 & 1.90 & .88 & .11 & 1.06 & 1.20 & .80 & .47 \\
\hline Cadmium & 1.1 & 23 & 23 & 22 & 23 & 23.0 & 8.33 & 1.33 & 10.6 & 11.3 & 6.20 & 3.00 \\
\hline Chromium & 11 & 23 & 22 & 9 & 23 & 21 & 9.7 & 1.0 & 11 & 12 & 9 & 6.3 \\
\hline Cobalt & 3.06 & 23 & 23 & 23 & 23 & 490 & 231 & 29.0 & 281 & 360 & 220 & 94.0 \\
\hline Copper & 11.8 & 23 & 23 & 22 & 23 & 19,000 & 7,200 & 1,150 & 9,150 & 12,000 & 7,000 & 2,600 \\
\hline Iron & 1,000 & 17 & 17 & 16 & 17 & 100,000 & 26,300 & 7,580 & 39,500 & 32,400 & 15,000 & 4,500 \\
\hline Lead & 3.2 & 23 & 22 & 1 & 23 & 5.00 & .89 & .22 & 1.27 & 1.10 & .60 & .27 \\
\hline Manganese & 80.3 & 23 & 23 & 23 & 23 & 3,600 & 1,660 & 172 & 1,960 & 2,100 & 1,780 & 1,080 \\
\hline Mercury & .012 & 10 & 0 & & & & & & & & & \\
\hline Nickel & 158 & 23 & 23 & 0 & 23 & 140 & 67 & 7.6 & 80 & 100 & 60 & 35 \\
\hline Selenium & 5 & 23 & 14 & 1 & 23 & 5.0 & 1.2 & .3 & 1.7 & 3.0 & .5 & .2 \\
\hline Silver & .36 & 23 & 16 & 0 & 21 & .12 & .04 & .01 & .06 & .07 & .03 & .01 \\
\hline Strontium & 620 & 23 & 23 & 0 & 23 & 180 & 93 & 9 & 108 & 130 & 100 & 60 \\
\hline Thallium & 18 & 23 & 12 & 0 & 21 & .16 & .07 & .01 & .08 & .10 & .06 & .04 \\
\hline Uranium & 1.87 & 15 & 15 & 6 & 15 & 3.60 & 1.87 & .28 & 2.36 & 2.90 & 1.60 & 1.20 \\
\hline Vanadium & 19.1 & 23 & 9 & 0 & 23 & 5.80 & .77 & .37 & 1.41 & .30 & .05 & .01 \\
\hline Zinc & 106 & 23 & 23 & 23 & 23 & 2,700 & 1,080 & 135 & 1,310 & 1,460 & 850 & 590 \\
\hline
\end{tabular}


Appendix 5. Summary of select constituents in surface waters relative to ambient water-quality criteria (AWOC) for stream reaches in the Ely Mine study area, Vershire, VT, 2000 to 2007.-Continued

[Values in italics are estimated; chronic, average allowable concentration; >, greater than; <, less than; \%, percent; SE, standard error; UCL, upper confidence level; Q3, 75th percentile; Q1, 25th percentile; mg/L, micrograms per liter]

\begin{tabular}{|c|c|c|c|c|c|c|c|c|c|c|c|c|}
\hline \multirow{3}{*}{ Element } & \multirow{3}{*}{$\begin{array}{c}\text { AWOC } \\
\text { chronic } \\
\text { ( } \mu \mathrm{g} / \mathrm{L})\end{array}$} & \multicolumn{11}{|c|}{ Ely Brook Tributary 4} \\
\hline & & \multirow[b]{2}{*}{ Samples } & \multirow[b]{2}{*}{ Detects } & \multirow{2}{*}{$\begin{array}{l}\text { Detects } \\
\text { >AWOC }\end{array}$} & \multirow{2}{*}{$\begin{array}{c}\text { Samples } \\
\text { used in } \\
\text { analysis }\end{array}$} & \multirow[b]{2}{*}{$\begin{array}{c}\text { Maximum } \\
\text { ( } \mu \mathrm{g} / \mathrm{L})\end{array}$} & \multicolumn{3}{|c|}{ Mean } & \multirow{2}{*}{$\begin{array}{c}03 \\
(\mu g / L)\end{array}$} & \multirow{2}{*}{$\begin{array}{l}\text { Median } \\
\text { ( } \mu \mathrm{g} / \mathrm{L})\end{array}$} & \multirow[b]{2}{*}{$\begin{array}{c}01 \\
(\mu \mathrm{g} / \mathrm{L})\end{array}$} \\
\hline & & & & & & & $\begin{array}{l}\text { Value } \\
\text { ( } \mu \mathrm{g} / \mathrm{L})\end{array}$ & $\begin{array}{c}\text { SE } \\
(\mu \mathrm{g} / \mathrm{L})\end{array}$ & $\begin{array}{c}95 \% \text { UCL } \\
(\mu \mathrm{g} / \mathrm{L})\end{array}$ & & & \\
\hline Aluminum & 87 & 5 & 5 & 5 & 5 & $>200,000$ & 47,600 & 32,300 & 112,800 & 102,500 & 5,850 & 2,250 \\
\hline Antimony & 104 & 6 & 2 & 0 & 6 & .08 & .04 & .01 & .06 & .06 & .03 & .02 \\
\hline Arsenic & 190 & 6 & 2 & 0 & 3 & .42 & & & & & & \\
\hline Barium & 3.8 & 6 & 6 & 6 & 6 & 38 & 24 & 5.2 & 35 & 37 & 26 & 12 \\
\hline Beryllium & 5.09 & 6 & 6 & 0 & 6 & 2.70 & 1.05 & .48 & 2.01 & 2.48 & .42 & .19 \\
\hline Cadmium & 1.1 & 6 & 6 & 6 & 6 & 25.0 & 9.48 & 4.61 & 18.8 & 23.5 & 2.85 & 1.80 \\
\hline Chromium & 11 & 6 & 5 & 2 & 6 & 120 & 33 & 21 & 77 & 88 & .6 & .4 \\
\hline Cobalt & 3.06 & 6 & 6 & 6 & 6 & 1,600 & 539 & 305 & 1,150 & 1,450 & 85.2 & 37.0 \\
\hline Copper & 11.8 & 6 & 6 & 6 & 6 & 76,000 & 22,800 & 13,400 & 49,800 & 58,000 & 3,260 & 1,260 \\
\hline Iron & 1000 & 3 & 2 & 2 & 3 & 17,000 & & & & & & \\
\hline Lead & 3.2 & 6 & 5 & 0 & 6 & .29 & .17 & .04 & .24 & .22 & .18 & .08 \\
\hline Manganese & 80.3 & 6 & 6 & 6 & 6 & 5,700 & 2,090 & 1,070 & 4,240 & 5,320 & 616 & 217 \\
\hline Mercury & .012 & 3 & 0 & & & & & & & & & \\
\hline Nickel & 158 & 6 & 6 & 2 & 6 & 380 & 136 & 72.6 & 283 & 358 & 33.0 & 12.0 \\
\hline Selenium & 5 & 6 & 4 & 2 & 6 & 6.4 & 2.3 & 1.2 & 4.7 & 5.9 & .7 & .2 \\
\hline Silver & .36 & 6 & 2 & 0 & 3 & .07 & & & & & & \\
\hline Strontium & 620 & 6 & 6 & 0 & 6 & 180 & 106 & 29 & 164 & 180 & 110 & 30 \\
\hline Thallium & 18 & 6 & 4 & 0 & 6 & .20 & .11 & .03 & .16 & .18 & .08 & .06 \\
\hline Uranium & 1.87 & 3 & 3 & 2 & 3 & 8.20 & & & & & & \\
\hline Vanadium & 19.1 & 6 & 1 & 0 & 2 & .07 & & & & & & \\
\hline Zinc & 106 & 6 & 6 & 6 & 6 & 2,500 & 965 & 456 & 1,880 & 2,350 & 308 & 202 \\
\hline
\end{tabular}


Appendix 5. Summary of select constituents in surface waters relative to ambient water-quality criteria (AWQC) for stream reaches in the Ely Mine study area, Vershire, VT, 2000 to 2007.-Continued

[Values in italics are estimated; chronic, average allowable concentration; >, greater than; <, less than; \%, percent; SE, standard error; UCL, upper confidence level; Q3, 75th percentile; Q1, 25th percentile; mg/L, micrograms per liter]

\begin{tabular}{|c|c|c|c|c|c|c|c|c|c|c|c|c|}
\hline \multirow{3}{*}{ Element } & \multirow{3}{*}{$\begin{array}{c}\text { AWQC } \\
\text { chronic } \\
\text { ( } \mu \mathrm{g} / \mathrm{L})\end{array}$} & \multicolumn{11}{|c|}{ Schoolhouse Brook from river meter 0 to 2,915 } \\
\hline & & \multirow[b]{2}{*}{ Samples } & \multirow[b]{2}{*}{ Detects } & \multirow{2}{*}{$\begin{array}{l}\text { Detects } \\
>\text { AWOC }\end{array}$} & \multirow{2}{*}{$\begin{array}{l}\text { Samples } \\
\text { used in } \\
\text { analysis }\end{array}$} & \multirow{2}{*}{$\begin{array}{c}\text { Maximum } \\
\text { ( } \mu \mathrm{g} / \mathrm{L})\end{array}$} & \multicolumn{3}{|c|}{ Mean } & \multirow{2}{*}{$\begin{array}{c}03 \\
(\mu g / L)\end{array}$} & \multirow{2}{*}{$\begin{array}{c}\text { Median } \\
\text { ( } \mu \mathrm{g} / \mathrm{L})\end{array}$} & \multirow{2}{*}{$\begin{array}{c}01 \\
(\mu g / L)\end{array}$} \\
\hline & & & & & & & $\begin{array}{l}\text { Value } \\
\text { ( } \mu \mathrm{g} / \mathrm{L})\end{array}$ & $\begin{array}{c}\text { SE } \\
(\mu \mathrm{g} / \mathrm{L})\end{array}$ & $\begin{array}{c}95 \% \text { UCL } \\
(\mu \mathrm{g} / \mathrm{L})\end{array}$ & & & \\
\hline Aluminum & 87 & 16 & 16 & 14 & 16 & 700 & 226 & 39 & 293 & 263 & 208 & 142 \\
\hline Antimony & 104 & 15 & 5 & 0 & 14 & 1.70 & .16 & .12 & .37 & .08 & .02 & $<.01$ \\
\hline Barium & 3.8 & 15 & 15 & 15 & 15 & 325 & 42 & 20 & 78 & 25 & 18 & 15 \\
\hline Beryllium & 5.09 & 15 & 0 & & & & & & & & & \\
\hline Cadmium & 1.1 & 19 & 12 & 0 & 17 & .25 & .09 & .01 & .12 & .13 & .08 & .05 \\
\hline Chromium & 11 & 19 & 3 & 0 & 3 & .21 & & & & & & \\
\hline Cobalt & 3.06 & 19 & 17 & 8 & 19 & 5.80 & 2.39 & .34 & 2.98 & 3.40 & 2.30 & 1.40 \\
\hline Manganese & 80.3 & 19 & 19 & 0 & 19 & 35.9 & 17.2 & 2.2 & 20.9 & 23.0 & 16.6 & 13.6 \\
\hline Mercury & .012 & 8 & 1 & 1 & 2 & .17 & & & & & & \\
\hline Nickel & 158 & 19 & 18 & 0 & 19 & 1.7 & 1.0 & 1.0 & 1.1 & 1.3 & 1.0 & .7 \\
\hline Selenium & 5 & 19 & 3 & 0 & 9 & .5 & & & & & & \\
\hline Silver & .36 & 19 & 1 & 0 & 8 & .06 & & & & & & \\
\hline Strontium & 620 & 14 & 14 & 0 & 14 & 230 & 133 & 14 & 158 & 161 & 145 & 77 \\
\hline Thallium & 18 & 19 & 0 & & & & & & & & & \\
\hline Uranium & 1.87 & 11 & 11 & 0 & 11 & .52 & .23 & .05 & .32 & .32 & .24 & .05 \\
\hline
\end{tabular}


Appendix 5. Summary of select constituents in surface waters relative to ambient water-quality criteria (AWOC) for stream reaches in the Ely Mine study area, Vershire, VT, 2000 to 2007.-Continued

[Values in italics are estimated; chronic, average allowable concentration; >, greater than; <, less than; \%, percent; SE, standard error; UCL, upper confidence level; Q3, 75th percentile; Q1, 25th percentile; mg/L, micrograms per liter]

\begin{tabular}{|c|c|c|c|c|c|c|c|c|c|c|c|c|}
\hline \multirow{3}{*}{ Element } & \multirow{3}{*}{$\begin{array}{c}\text { AWOC } \\
\text { chronic } \\
\text { ( } \mu \mathrm{g} / \mathrm{L})\end{array}$} & \multicolumn{11}{|c|}{ Schoolhouse Brook from river meter 2,915 to 3,270} \\
\hline & & \multirow[b]{2}{*}{ Samples } & \multirow[b]{2}{*}{ Detects } & \multirow[b]{2}{*}{$\begin{array}{l}\text { Detects } \\
>\text { AWOC }\end{array}$} & \multirow{2}{*}{$\begin{array}{l}\text { Samples } \\
\text { used in } \\
\text { analysis }\end{array}$} & \multirow[b]{2}{*}{$\begin{array}{c}\text { Maximum } \\
(\mu \mathrm{g} / \mathrm{L})\end{array}$} & \multicolumn{3}{|c|}{ Mean } & \multirow{2}{*}{$\begin{array}{c}03 \\
(\mu \mathrm{g} / \mathrm{L})\end{array}$} & \multirow{2}{*}{$\begin{array}{c}\text { Median } \\
\text { ( } \mu \mathrm{g} / \mathrm{L})\end{array}$} & \multirow{2}{*}{$\begin{array}{c}01 \\
(\mu g / L)\end{array}$} \\
\hline & & & & & & & $\begin{array}{l}\text { Value } \\
(\mu \mathrm{g} / \mathrm{L})\end{array}$ & $\begin{array}{c}S E \\
(\mu g / L)\end{array}$ & $\begin{array}{c}95 \% \text { UCL } \\
(\mu \mathrm{g} / \mathrm{L})\end{array}$ & & & \\
\hline Aluminum & 87 & 17 & 17 & 15 & 17 & 1,400 & 409 & 75 & 540 & 455 & 360 & 280 \\
\hline Antimony & 104 & 16 & 6 & 0 & 11 & .78 & .11 & .07 & .23 & .10 & .02 & .01 \\
\hline Barium & 3.8 & 16 & 16 & 16 & 16 & 289 & 41 & 17 & 71 & 28 & 19 & 16 \\
\hline Beryllium & 5.09 & 16 & 0 & & & & & & & & & \\
\hline Cadmium & 1.1 & 20 & 12 & 0 & 17 & .46 & .16 & .02 & .20 & .21 & .13 & .10 \\
\hline Chromium & 11 & 20 & 6 & 0 & 11 & .54 & .23 & .04 & .30 & .29 & .18 & .15 \\
\hline Cobalt & 3.06 & 20 & 20 & 16 & 20 & 11.0 & 4.56 & .48 & 5.40 & 5.28 & 3.95 & 3.22 \\
\hline Manganese & 80.3 & 20 & 20 & 0 & 20 & 62.0 & 33.6 & 2.3 & 37.7 & 39.9 & 34.0 & 27.4 \\
\hline Mercury & .012 & 12 & 2 & 2 & 4 & .14 & & & & & & \\
\hline Nickel & 158 & 20 & 19 & 0 & 20 & 2.3 & 1.4 & .1 & 1.6 & 1.7 & 1.4 & 1.2 \\
\hline Selenium & 5 & 20 & 4 & 0 & 11 & .4 & .2 & .03 & .2 & .3 & .1 & .1 \\
\hline Silver & .36 & 20 & 1 & 0 & 8 & .02 & & & & & & \\
\hline Strontium & 620 & 15 & 15 & 0 & 15 & 260 & 135 & 16 & 162 & 160 & 157 & 76 \\
\hline Thallium & 18 & 20 & 0 & & & & & & & & & \\
\hline Uranium & 1.87 & 9 & 9 & 0 & 9 & .55 & .23 & .07 & .36 & .42 & .14 & .05 \\
\hline
\end{tabular}


Appendix 5. Summary of select constituents in surface waters relative to ambient water-quality criteria (AWQC) for stream reaches in the Ely Mine study area, Vershire, VT, 2000 to 2007.-Continued

[Values in italics are estimated; chronic, average allowable concentration; >, greater than; <, less than; \%, percent; SE, standard error; UCL, upper confidence level; Q3, 75th percentile; Q1, 25th percentile; mg/L, micrograms per liter]

\begin{tabular}{|c|c|c|c|c|c|c|c|c|c|c|c|c|}
\hline \multirow{3}{*}{ Element } & \multirow{3}{*}{ 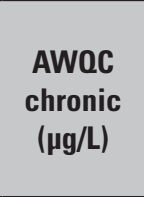 } & \multicolumn{11}{|c|}{ Schoolhouse Brook above river meter 3,270 } \\
\hline & & \multirow[b]{2}{*}{ Samples } & \multirow[b]{2}{*}{ Detects } & \multirow{2}{*}{$\begin{array}{l}\text { Detects } \\
>\text { AWOC }\end{array}$} & \multirow{2}{*}{$\begin{array}{l}\text { Samples } \\
\text { used in } \\
\text { analysis }\end{array}$} & \multirow[b]{2}{*}{$\begin{array}{c}\text { Maximum } \\
(\mu \mathrm{g} / \mathrm{L})\end{array}$} & \multicolumn{3}{|c|}{ Mean } & \multirow{2}{*}{$\begin{array}{c}03 \\
(\mu \mathrm{g} / \mathrm{L})\end{array}$} & \multirow{2}{*}{$\begin{array}{c}\text { Median } \\
(\mu \mathrm{g} / \mathrm{L})\end{array}$} & \multirow{2}{*}{$\begin{array}{c}01 \\
(\mu g / L)\end{array}$} \\
\hline & & & & & & & $\begin{array}{l}\text { Value } \\
\text { ( } \mu \mathrm{g} / \mathrm{L})\end{array}$ & $\begin{array}{c}\text { SE } \\
(\mu \mathrm{g} / \mathrm{L})\end{array}$ & $\begin{array}{c}95 \% \text { UCL } \\
(\mu \mathrm{g} / \mathrm{L})\end{array}$ & & & \\
\hline Aluminum & 87 & 13 & 13 & 6 & 13 & 730 & 163 & 60 & 270 & 228 & 52 & 32 \\
\hline Antimony & 104 & 12 & 4 & 0 & 9 & .22 & .06 & .02 & .10 & .09 & .02 & .01 \\
\hline Arsenic & 190 & 12 & 0 & & & & & & & & & \\
\hline Barium & 3.8 & 12 & 12 & 12 & 12 & 110 & 33 & 8.4 & 48 & 28 & 23 & 18 \\
\hline Beryllium & 5.09 & 12 & 0 & & & & & & & & & \\
\hline Cadmium & 1.1 & 14 & 1 & 0 & 14 & .02 & & & & & & \\
\hline Chromium & 11 & 14 & 3 & 0 & 5 & .58 & & & & & & \\
\hline Cobalt & 3.06 & 14 & 4 & 0 & 14 & 1.90 & .17 & .14 & .42 & .04 & $<.01$ & $<.01$ \\
\hline Copper & 11.8 & 14 & 6 & 0 & 14 & 1.1 & .5 & .1 & .7 & .9 & .4 & .3 \\
\hline Iron & 1,000 & 9 & 0 & & & & & & & & & \\
\hline Lead & 3.2 & 14 & 5 & 0 & 14 & 1.90 & .16 & .13 & .40 & .05 & .01 & $<.01$ \\
\hline Manganese & 80.3 & 14 & 14 & 0 & 14 & 8.5 & 5.6 & .3 & 6.2 & 6.0 & 5.5 & 5.0 \\
\hline Mercury & .012 & 4 & 0 & & & & & & & & & \\
\hline Nickel & 158 & 14 & 6 & 0 & 13 & .9 & .3 & .1 & .4 & .5 & .2 & .1 \\
\hline Selenium & 5 & 14 & 0 & & & & & & & & & \\
\hline Silver & .36 & 14 & 0 & & & & & & & & & \\
\hline Strontium & 620 & 11 & 11 & 0 & 11 & 230 & 134 & 19 & 168 & 170 & 130 & 82 \\
\hline Thallium & 18 & 14 & 0 & & & & & & & & & \\
\hline Uranium & 1.87 & 9 & 9 & 0 & 9 & .64 & .25 & .08 & .39 & .44 & .16 & .07 \\
\hline Vanadium & 19.1 & 14 & 5 & 0 & 12 & .40 & .16 & .03 & .21 & .20 & .13 & .07 \\
\hline Zinc & 106 & 14 & 13 & 0 & 14 & 49 & 13 & 4 & 20 & 24 & 4 & 2 \\
\hline
\end{tabular}


Appendix 5. Summary of select constituents in surface waters relative to ambient water-quality criteria (AWOC) for stream reaches in the Ely Mine study area, Vershire, VT, 2000 to 2007.-Continued

[Values in italics are estimated; chronic, average allowable concentration; >, greater than; <, less than; \%, percent; SE, standard error; UCL, upper confidence level; Q3, 75th percentile; Q1, 25th percentile; mg/L, micrograms per liter]

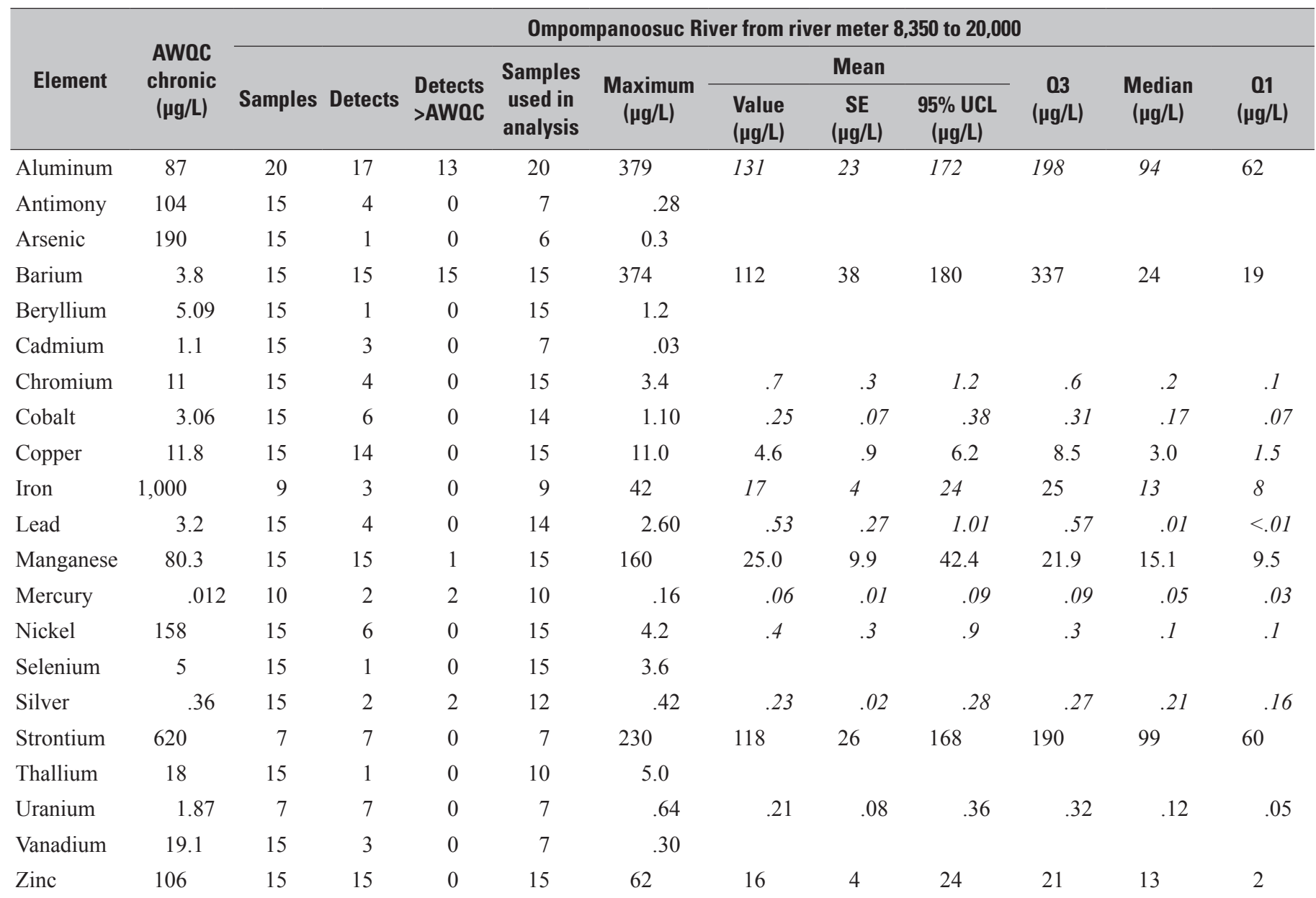


Appendix 5. Summary of select constituents in surface waters relative to ambient water-quality criteria (AWQC) for stream reaches in the Ely Mine study area, Vershire, VT, 2000 to 2007.-Continued

[Values in italics are estimated; chronic, average allowable concentration; >, greater than; <, less than; \%, percent; SE, standard error; UCL, upper confidence level; Q3, 75th percentile; Q1, 25th percentile; mg/L, micrograms per liter]

\begin{tabular}{|c|c|c|c|c|c|c|c|c|c|c|c|c|}
\hline \multirow{3}{*}{ Element } & \multirow{3}{*}{$\begin{array}{c}\text { AWQC } \\
\text { chronic } \\
\text { ( } \mu \mathrm{g} / \mathrm{L})\end{array}$} & \multicolumn{11}{|c|}{ Ompompanoosuc River from river meter 20,000 to 23,640} \\
\hline & & \multirow[b]{2}{*}{ Samples } & \multirow[b]{2}{*}{ Detects } & \multirow[b]{2}{*}{$\begin{array}{l}\text { Detects } \\
>\text { AWOC }\end{array}$} & \multirow{2}{*}{$\begin{array}{l}\text { Samples } \\
\text { used in } \\
\text { analysis }\end{array}$} & \multirow{2}{*}{$\begin{array}{l}\text { Maximum } \\
(\mu \mathrm{g} / \mathrm{L})\end{array}$} & \multicolumn{3}{|c|}{ Mean } & \multirow{2}{*}{$\begin{array}{c}03 \\
(\mu \mathrm{g} / \mathrm{L})\end{array}$} & \multirow{2}{*}{$\begin{array}{c}\text { Median } \\
\text { ( } \mu \mathrm{g} / \mathrm{L})\end{array}$} & \multirow{2}{*}{$\begin{array}{c}01 \\
(\mu g / L)\end{array}$} \\
\hline & & & & & & & $\begin{array}{l}\text { Value } \\
\text { ( } \mu \mathrm{g} / \mathrm{L})\end{array}$ & $\begin{array}{c}\text { SE } \\
(\mu \mathrm{g} / \mathrm{L})\end{array}$ & $\begin{array}{c}95 \% \text { UCL } \\
\text { ( } \mu \mathrm{g} / \mathrm{L})\end{array}$ & & & \\
\hline Aluminum & 87 & 11 & 11 & 6 & 11 & 470 & 144 & 46 & 227 & 140 & 118 & 38 \\
\hline Antimony & 104 & 10 & 6 & 0 & 10 & 3.00 & .34 & .30 & .88 & .09 & .04 & .02 \\
\hline Barium & 3.8 & 10 & 10 & 10 & 10 & 46 & 25 & 2.8 & 30 & 28 & 24 & 19 \\
\hline Beryllium & 5.09 & 10 & 0 & & & & & & & & & \\
\hline Cadmium & 1.1 & 10 & 6 & 0 & 9 & .10 & .04 & .01 & .06 & .07 & .02 & .01 \\
\hline Chromium & 11 & 10 & 2 & 0 & 10 & 1.0 & .3 & .1 & .4 & .3 & .2 & .1 \\
\hline Cobalt & 3.06 & 10 & 9 & 0 & 10 & 1.70 & .60 & .19 & .94 & 1.15 & .38 & .09 \\
\hline Manganese & 80.3 & 10 & 10 & 0 & 10 & 14.0 & 10.0 & .9 & 11.7 & 12.3 & 9.8 & 8.4 \\
\hline Mercury & .012 & 4 & 1 & 1 & 1 & .2 & & & & & & \\
\hline Nickel & 158 & 10 & 8 & 0 & 10 & .8 & .3 & .1 & .5 & .5 & .3 & .2 \\
\hline Selenium & 5 & 10 & 0 & & & & & & & & & \\
\hline Silver & .36 & 10 & 2 & 0 & 7 & .05 & .01 & .01 & .02 & .01 & $<.01$ & $<.01$ \\
\hline Strontium & 620 & 10 & 10 & 0 & 10 & 190 & 128 & 14 & 155 & 158 & 139 & 80 \\
\hline Thallium & 18 & 10 & 1 & 0 & 7 & .09 & & & & & & \\
\hline Uranium & 1.87 & 9 & 9 & 0 & 9 & .32 & .18 & .03 & .25 & .26 & .24 & .07 \\
\hline
\end{tabular}


Appendix 5. Summary of select constituents in surface waters relative to ambient water-quality criteria (AWOC) for stream reaches in the Ely Mine study area, Vershire, VT, 2000 to 2007.-Continued

[Values in italics are estimated; chronic, average allowable concentration; >, greater than; <, less than; \%, percent; SE, standard error; UCL, upper confidence level; Q3, 75th percentile; Q1, 25th percentile; mg/L, micrograms per liter]

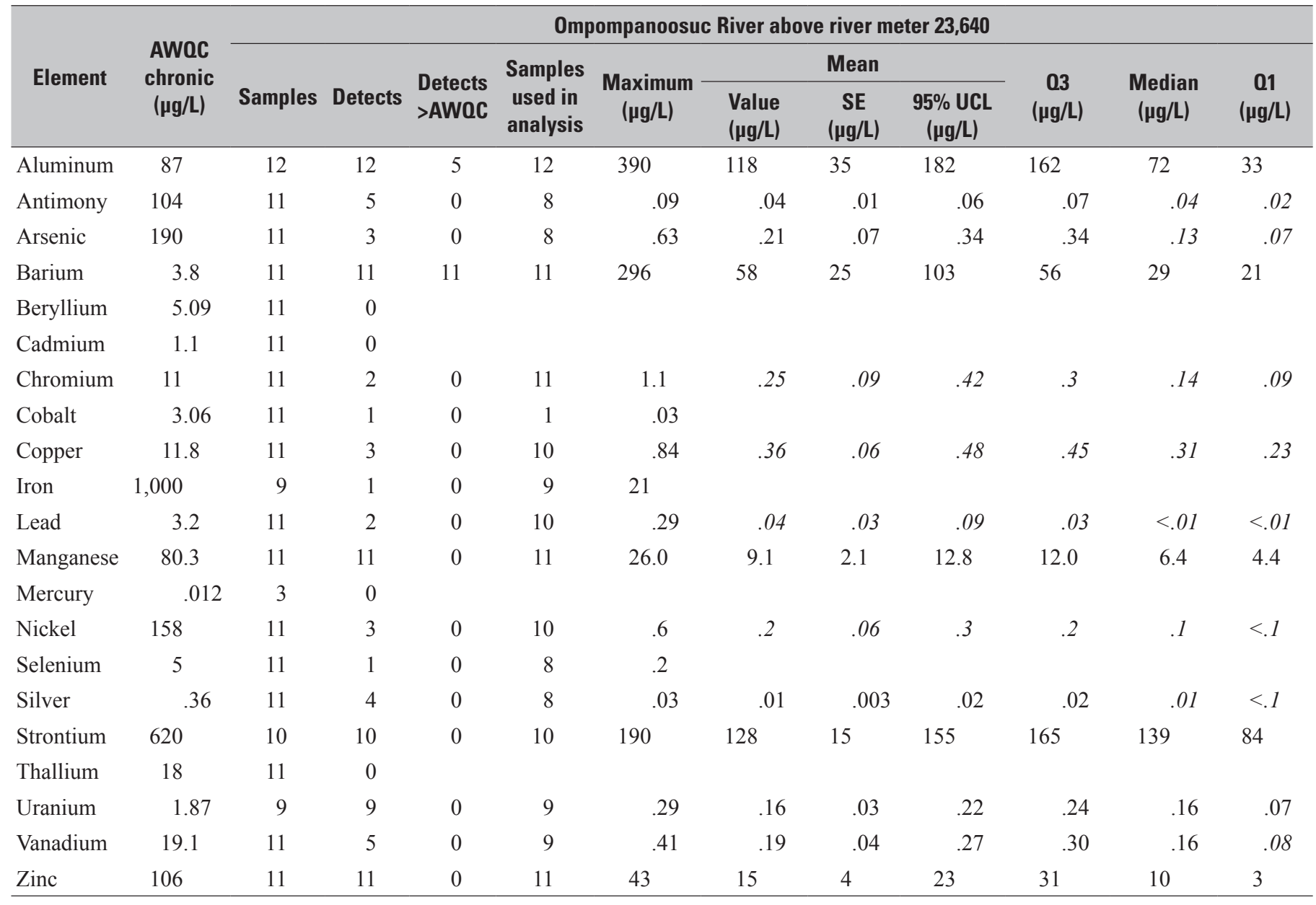

${ }^{a}$ Chronic toxicity standards for waters with $\mathrm{pH}$ 6.5-9.0 and for total recoverable concentrations (USEPA, 2006).

${ }^{\text {b }}$ From Suter, 1996.

c From VTDEC, 2006.

d Toxicity is hardness dependent and shown at hardness of 100 milligrams per liter. 



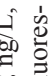

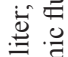

营

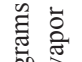

일

窃

䒬

要

突

旁 옹

5 苟

至

产

동

递

言

离

要

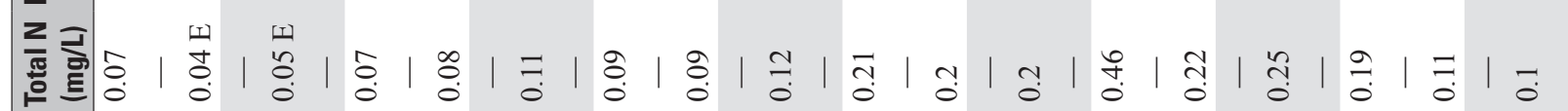

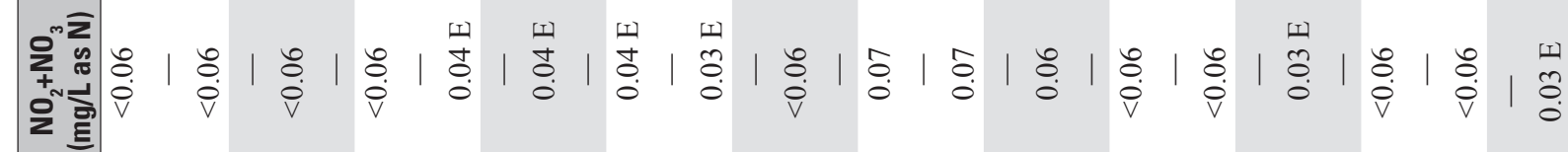

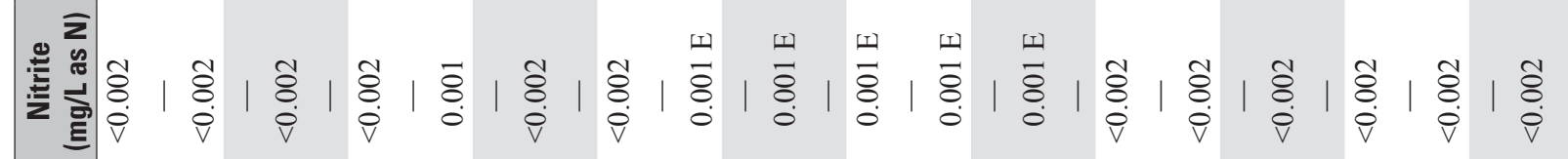

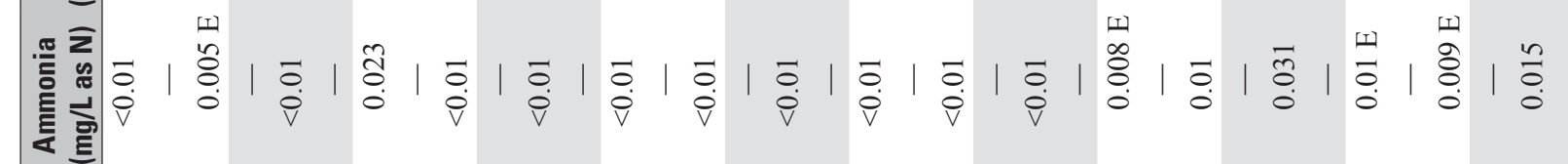

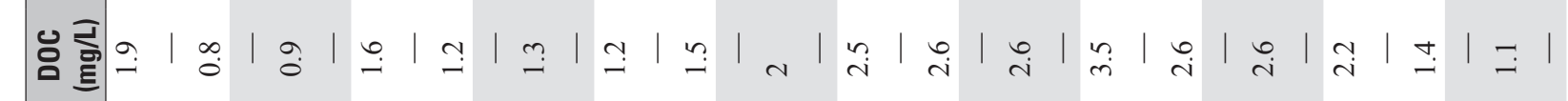
产 要言

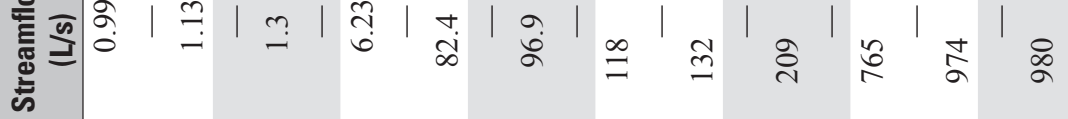

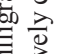
i. . $\sum_{1}^{2}$ 容

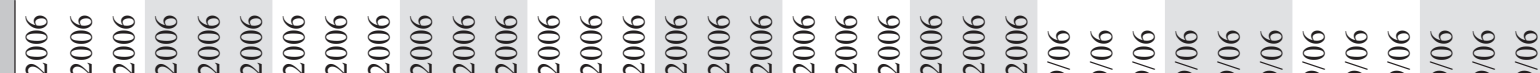
告

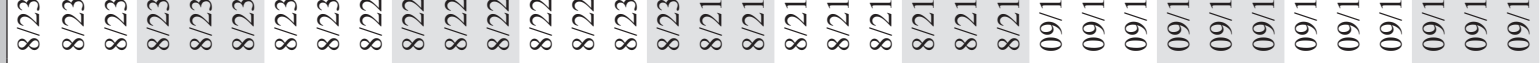

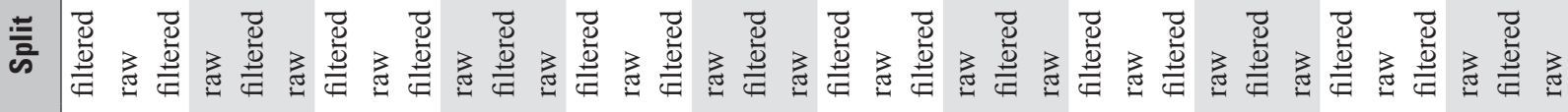

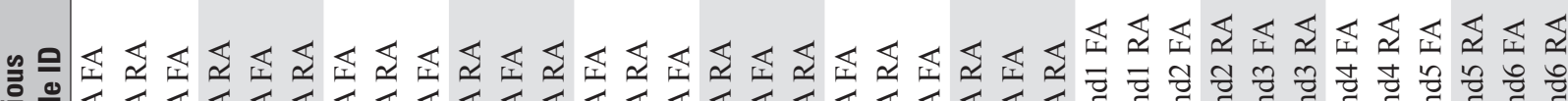

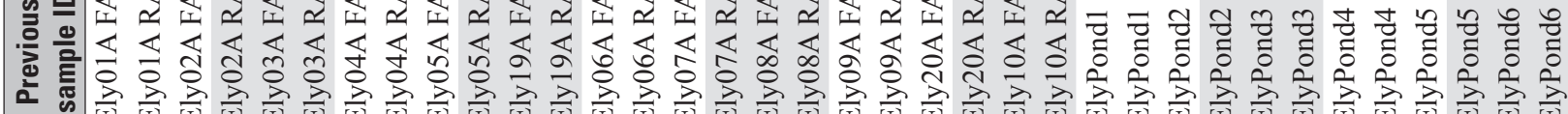

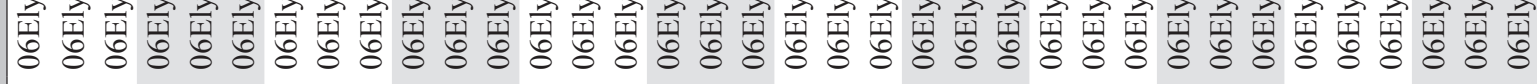

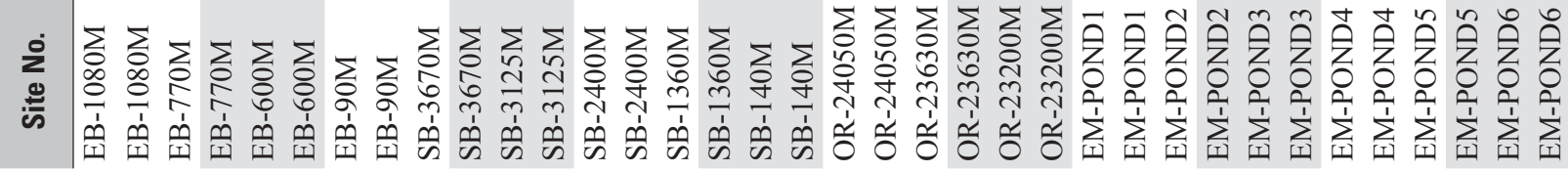




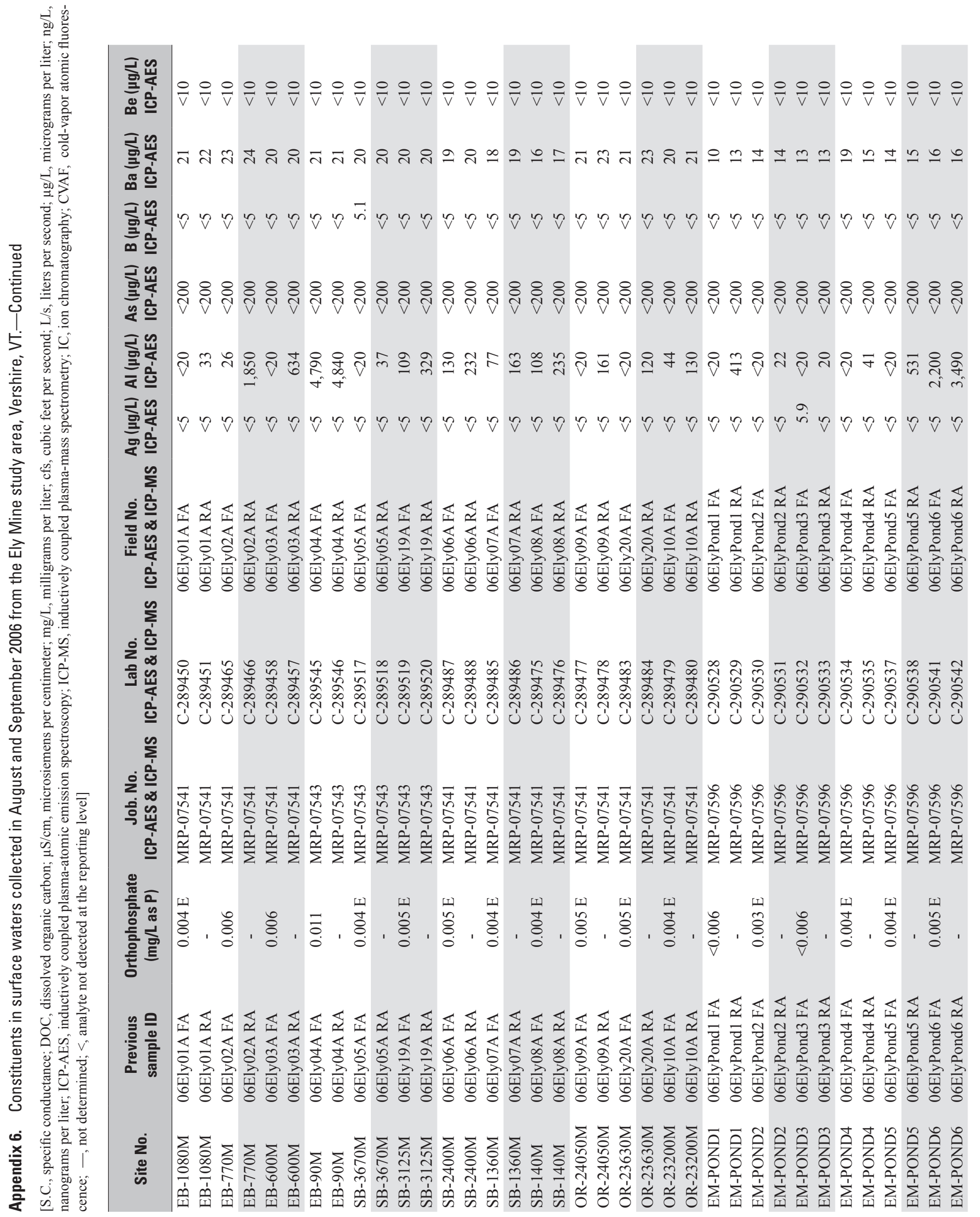


료묘 n

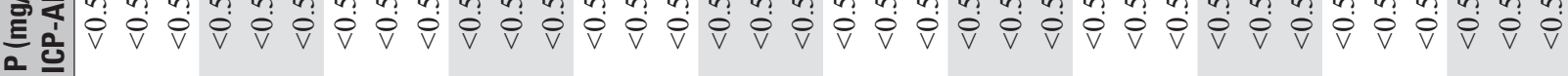

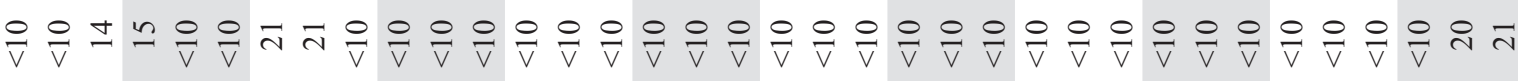

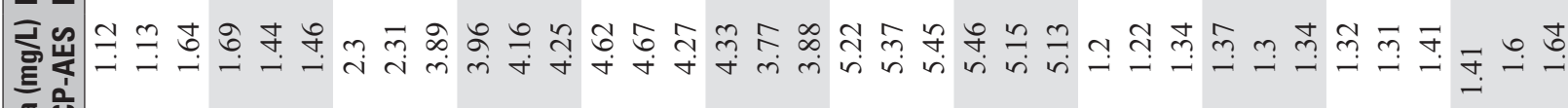
준 는

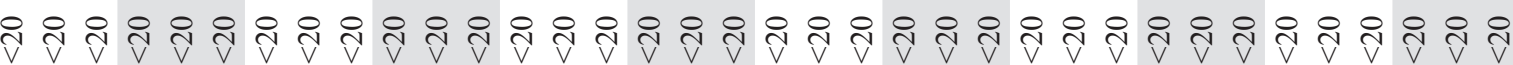

๗ 드으.

水 몰으

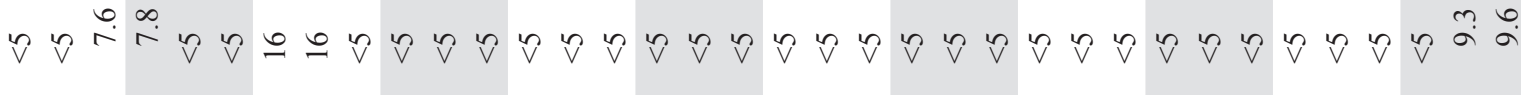

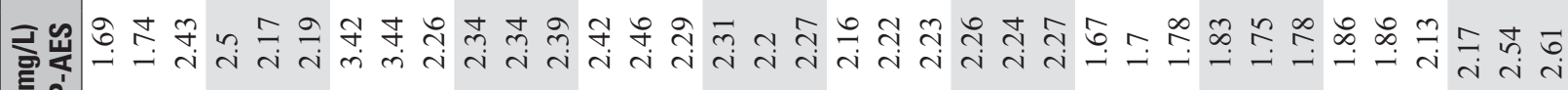
든 은

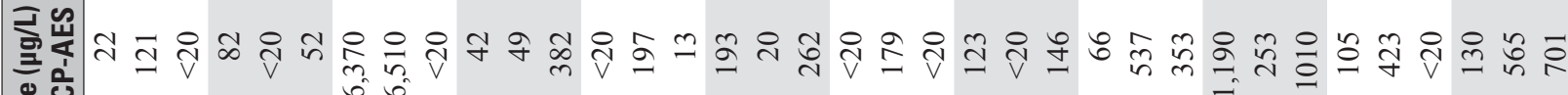
는 응 至出 롤 는 은

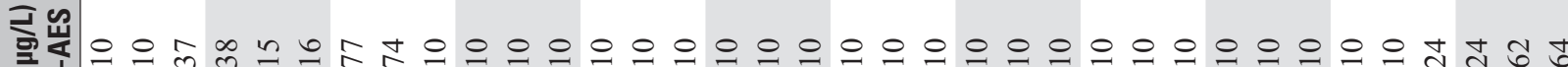
원

อ 헝연

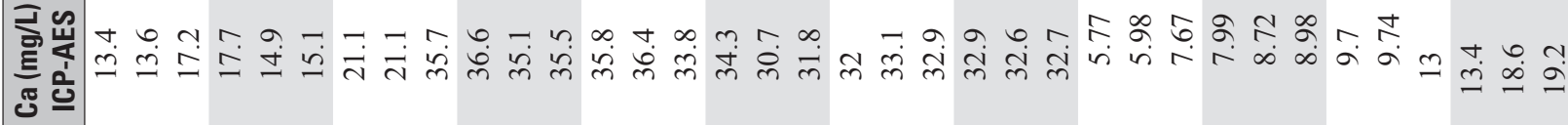

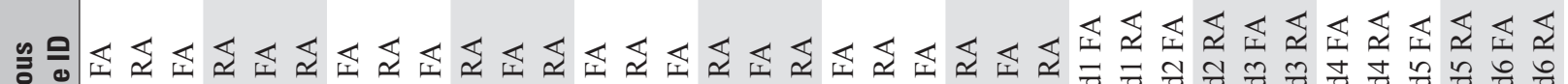

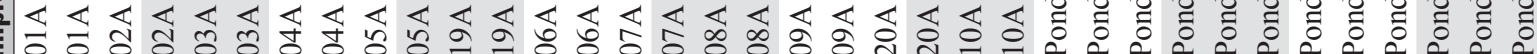

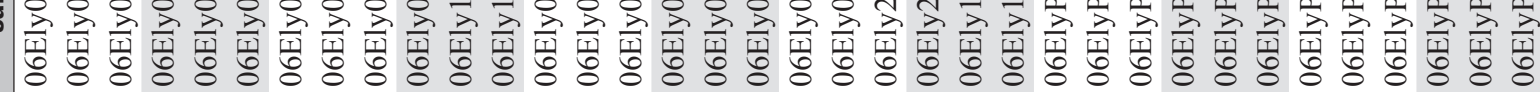

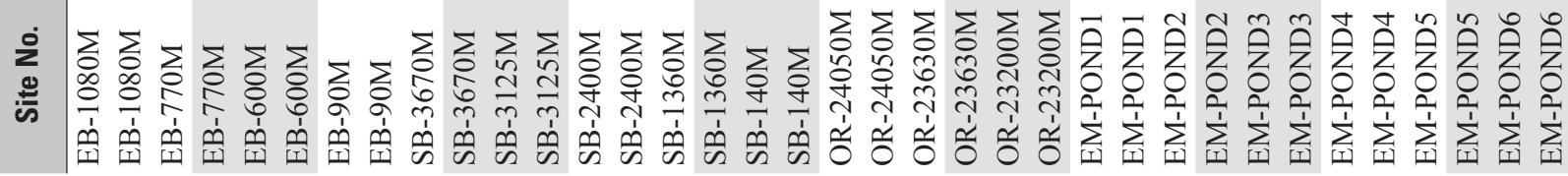


일

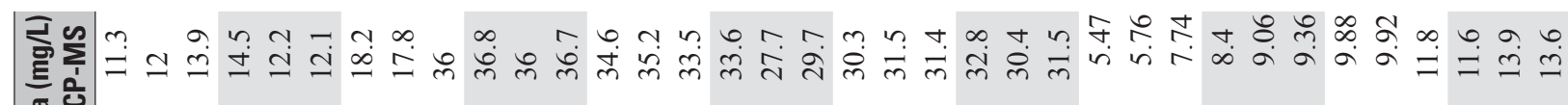
画

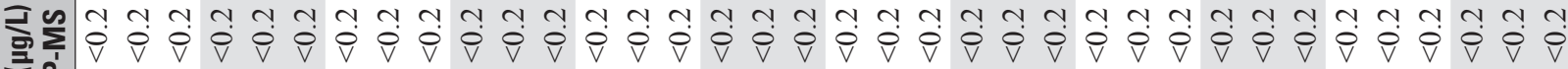
高

₹ $\sum_{1}^{\infty}$

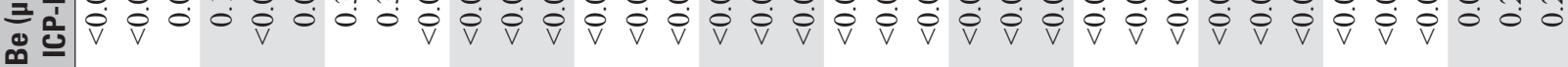

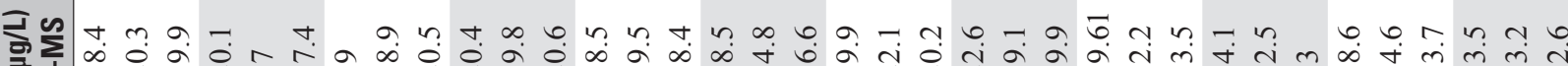
要

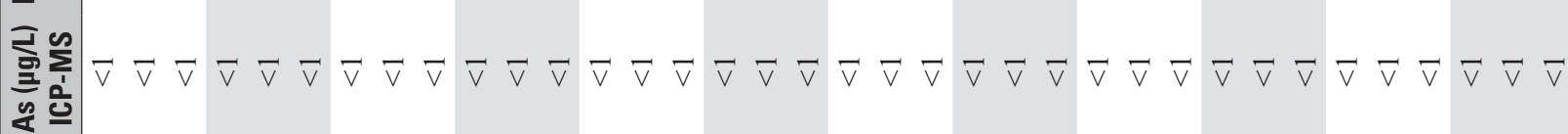

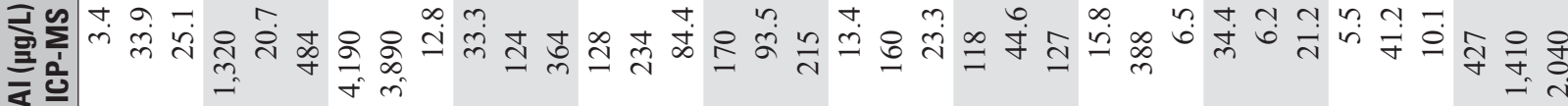
ริ) 舟衣 $\nabla \nabla \nabla \nabla \nabla \nabla \nabla \nabla \nabla \nabla \nabla \nabla \nabla \nabla \nabla \nabla \nabla \nabla \nabla \nabla \nabla \nabla \nabla \nabla \nabla \nabla \nabla \nabla \nabla \nabla \nabla \nabla \nabla \nabla \nabla \nabla$

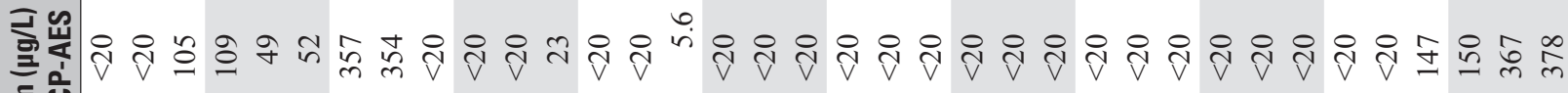
는

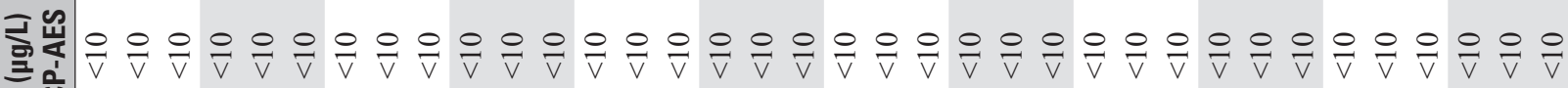
$>\underline{\underline{0}}$

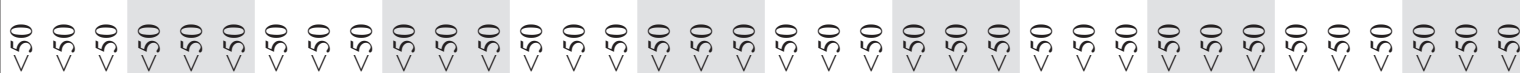

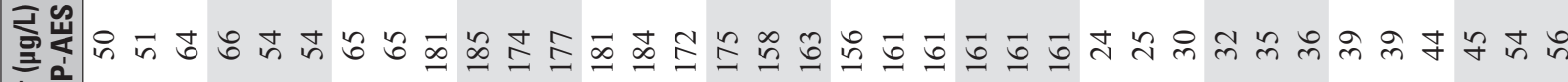
is 월

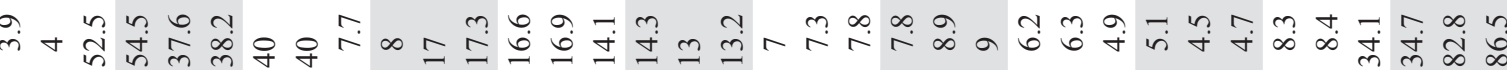
की 


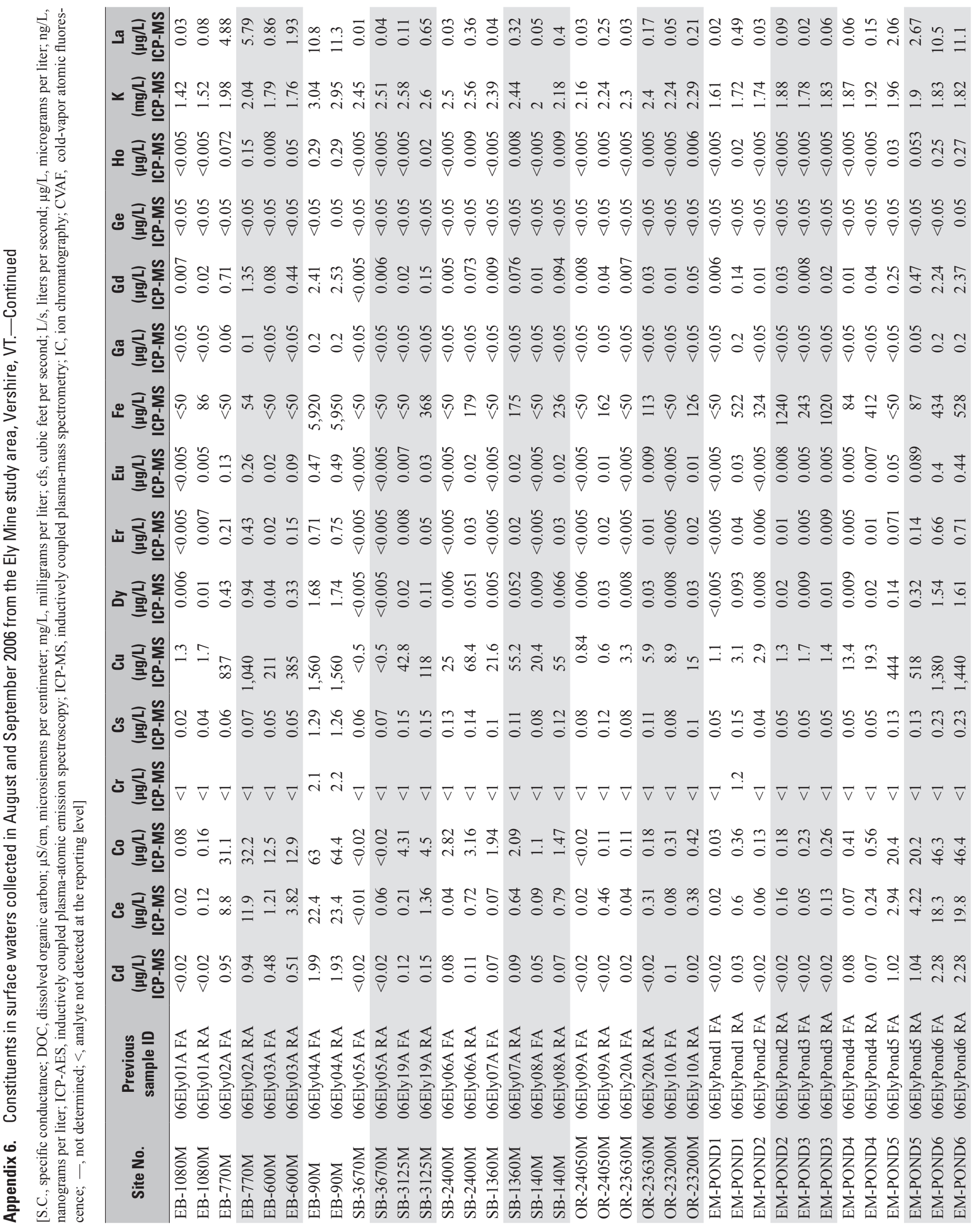




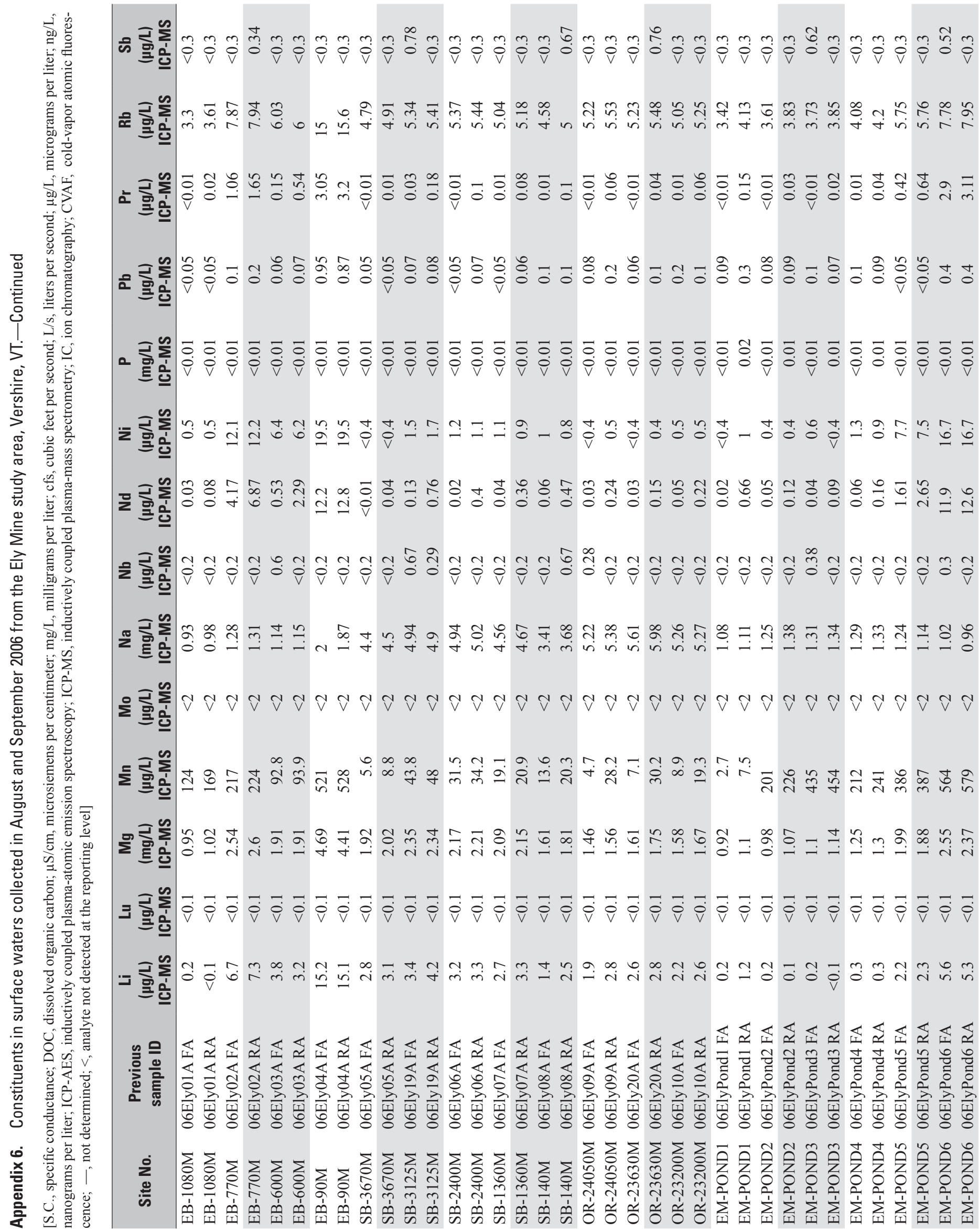




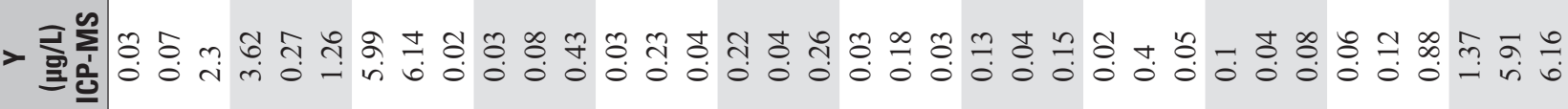

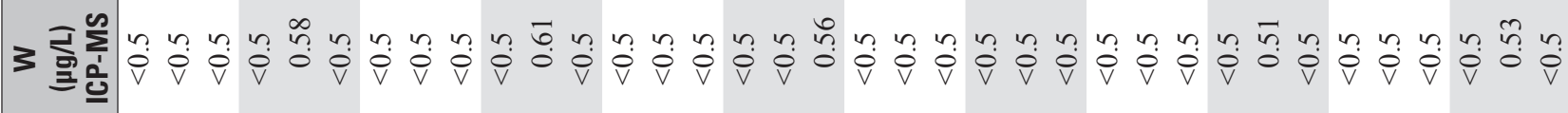

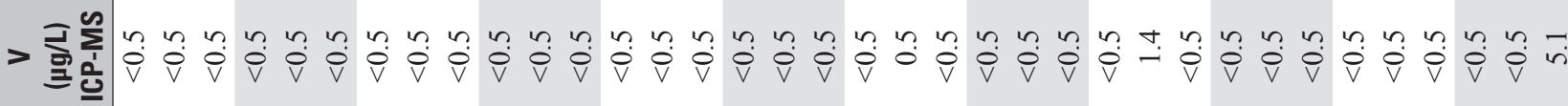

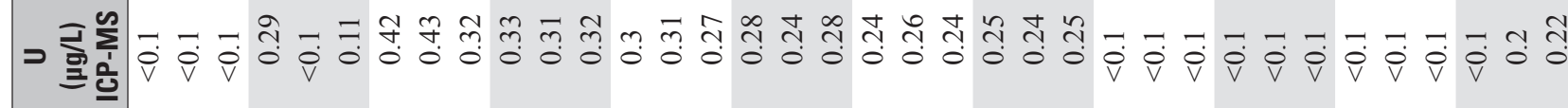

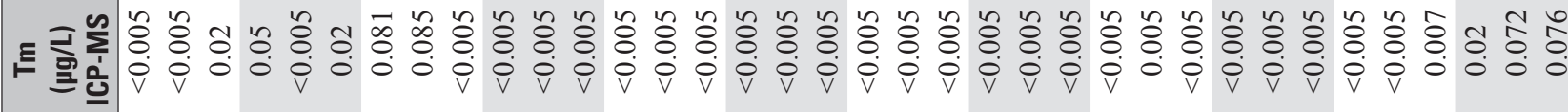

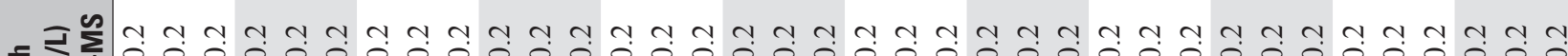

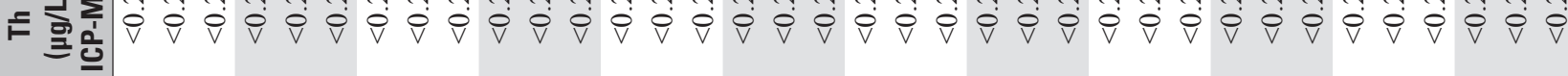

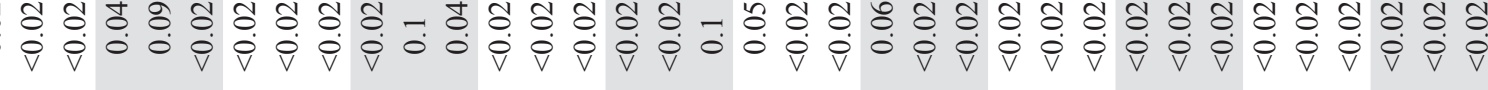

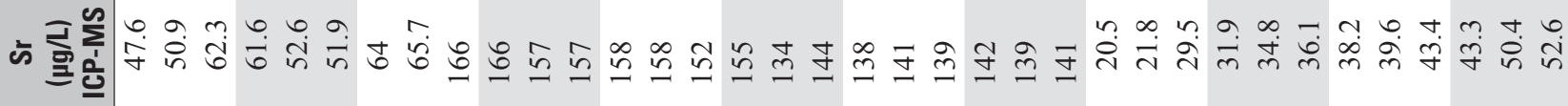

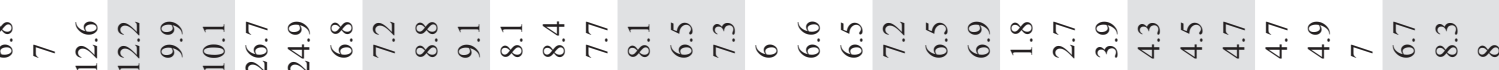

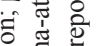

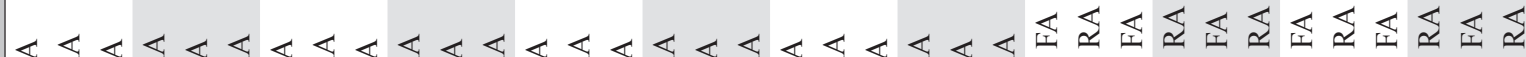




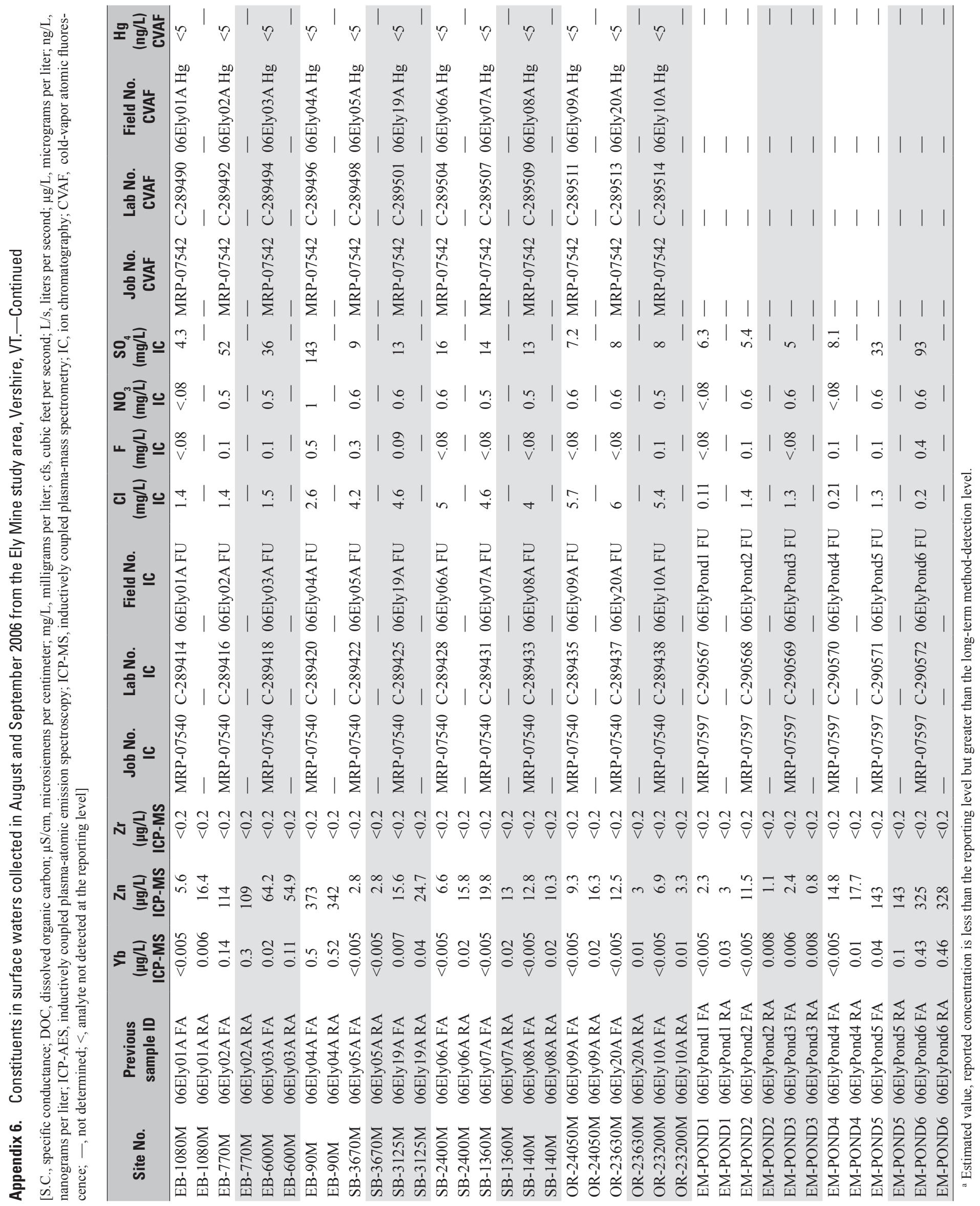




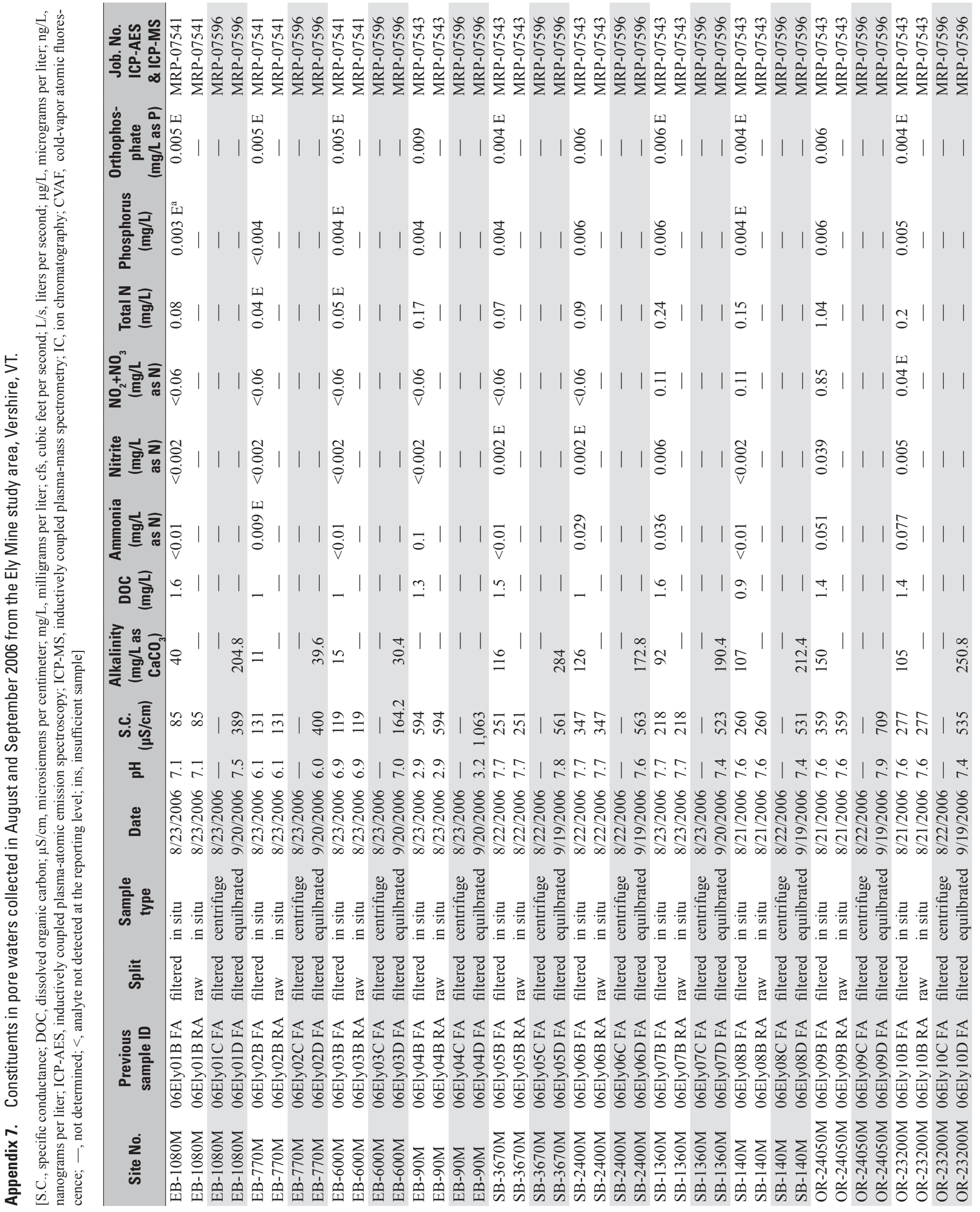




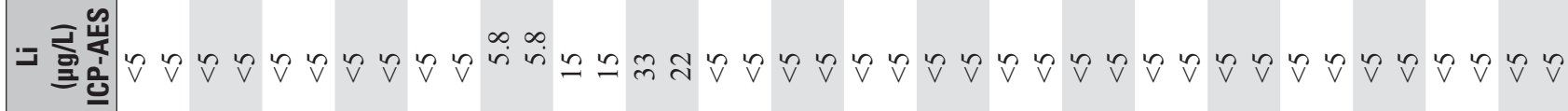

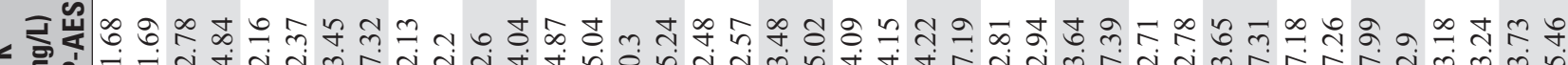

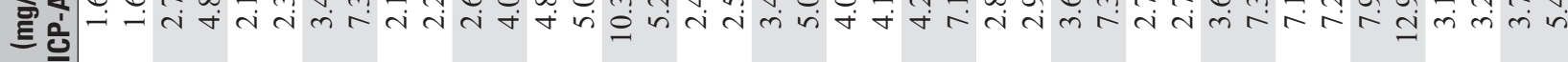

产

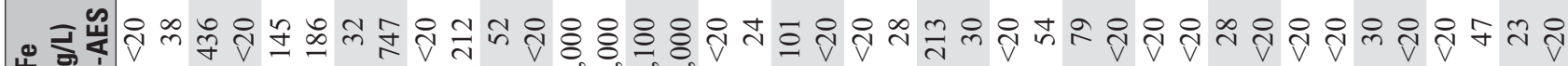
흘을 $\exists$ ‡

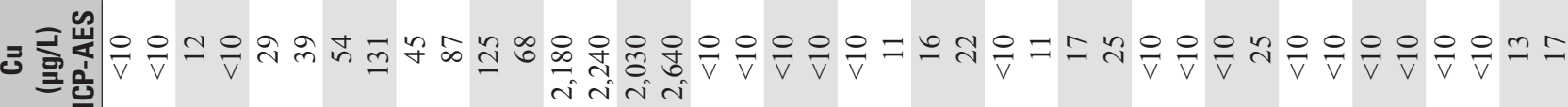

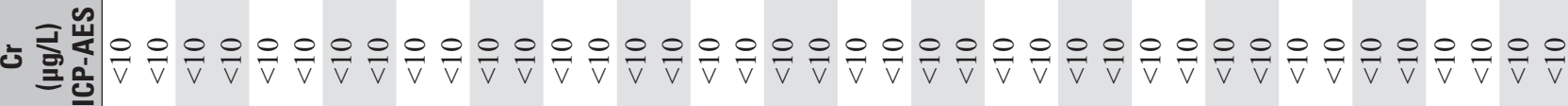

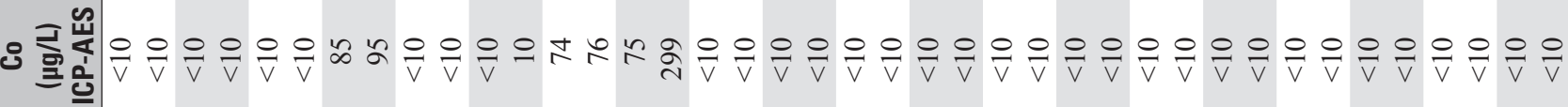

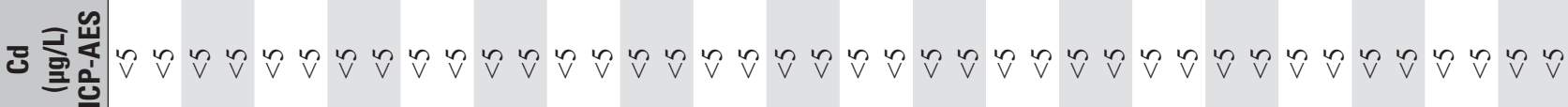

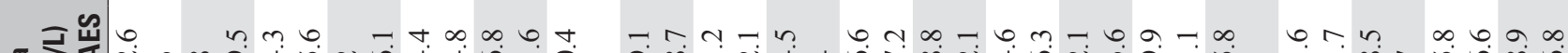

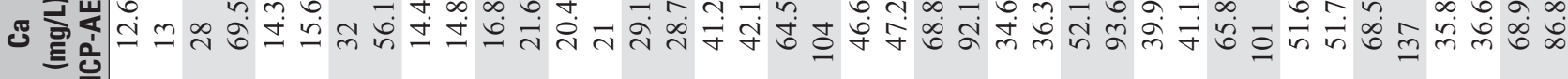

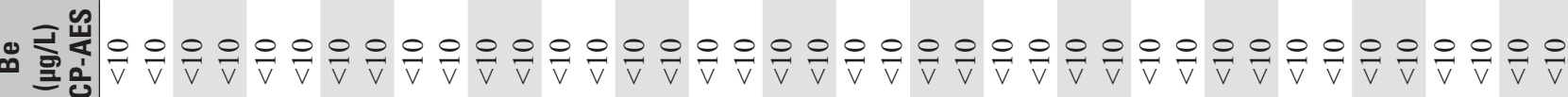

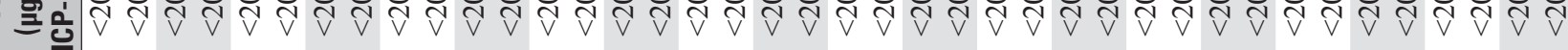
«

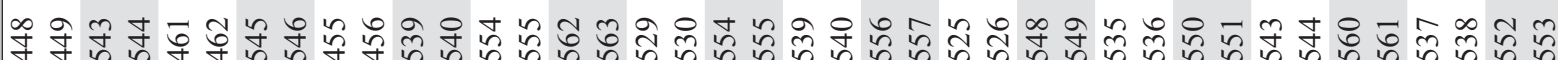

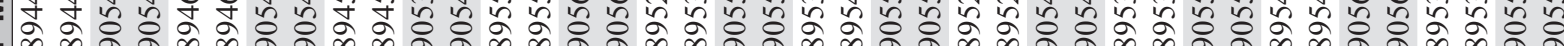

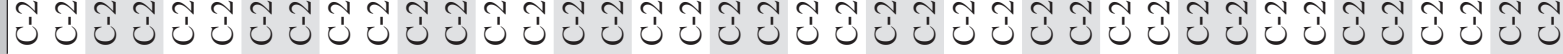
ن

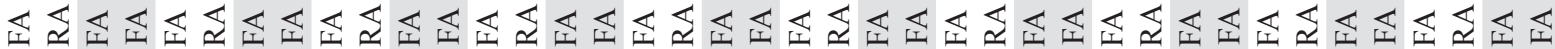

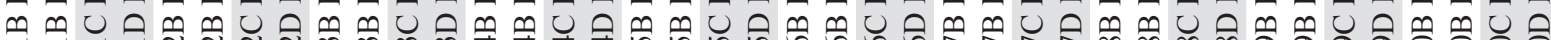




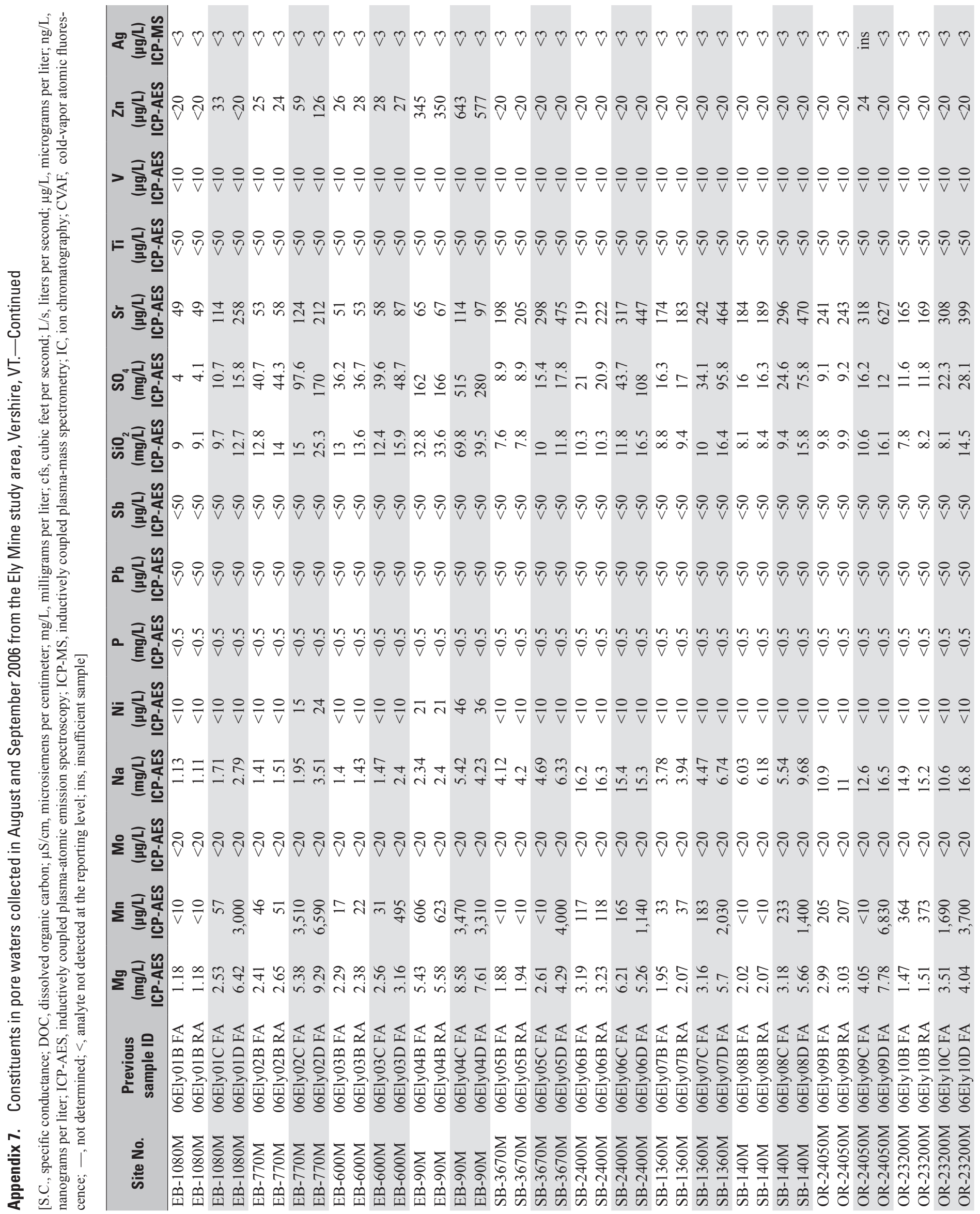




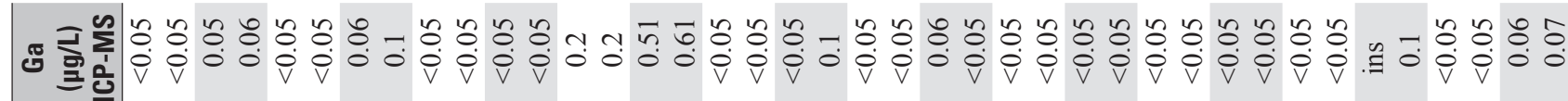

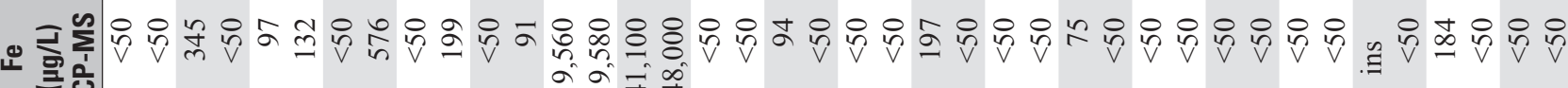
클을

范

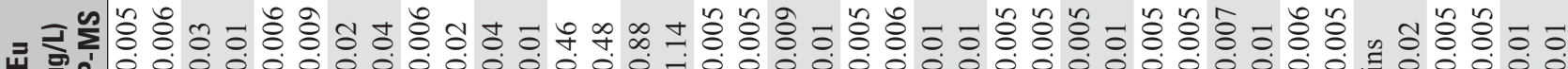

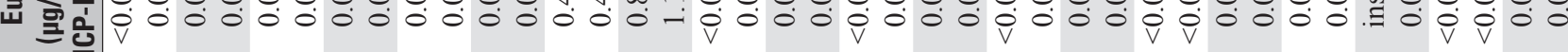

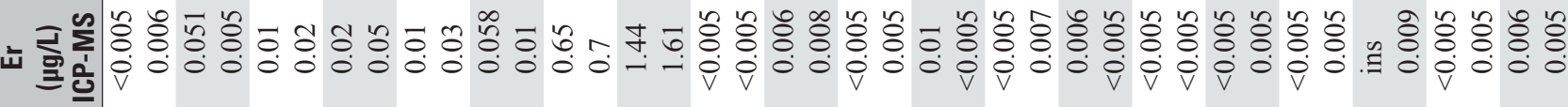

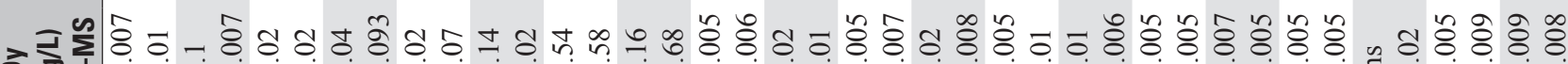

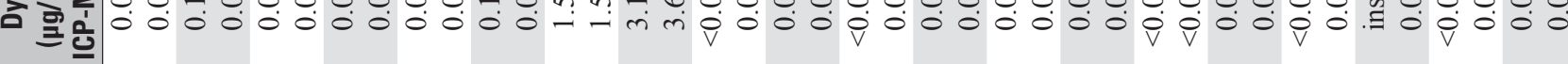
ت

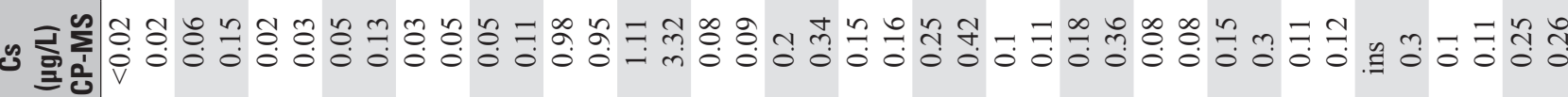

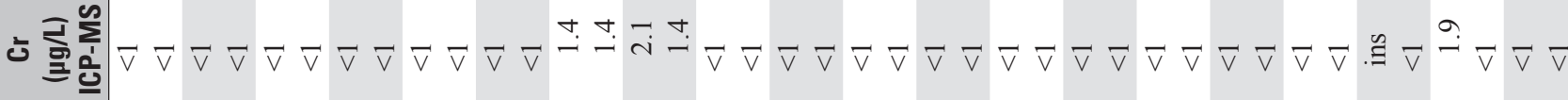

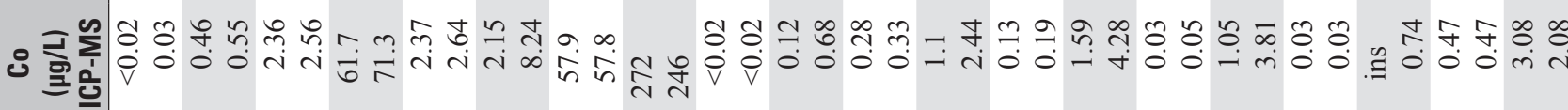

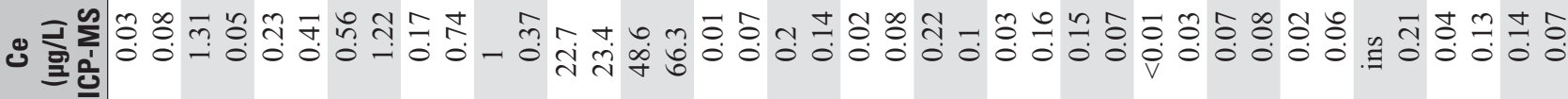

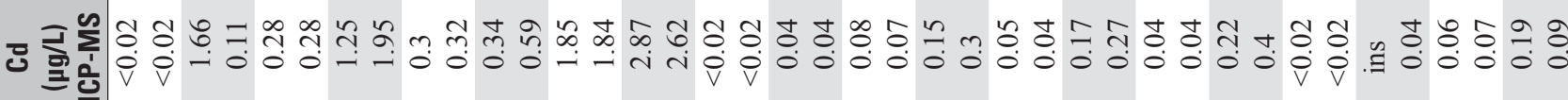

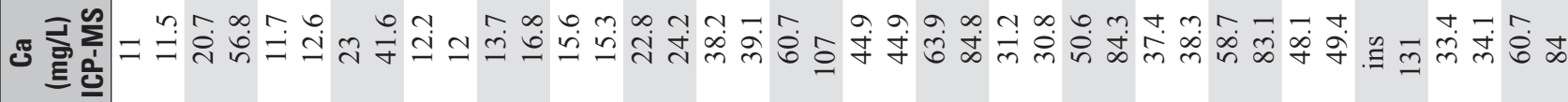
m

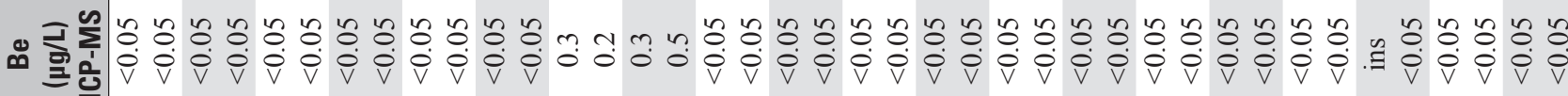
ש

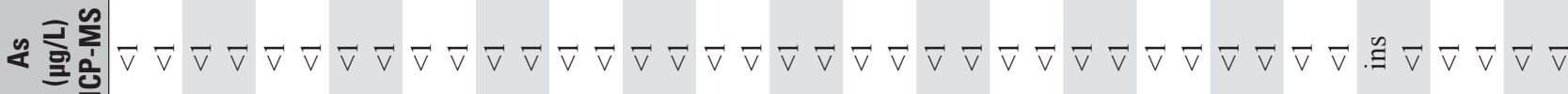

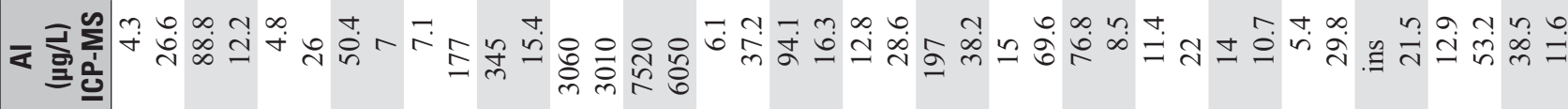

की

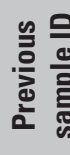

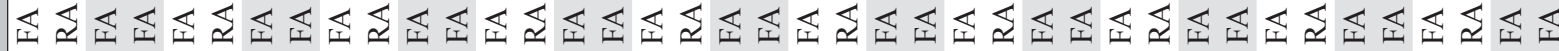
m

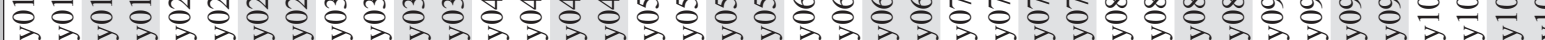

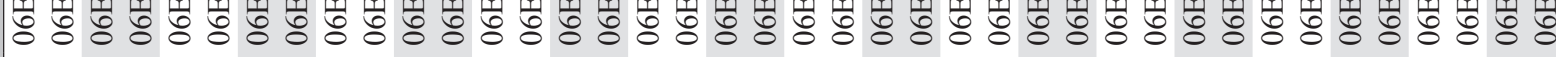
至 : $\sum \sum \sum \sum \sum \sum \sum$ 


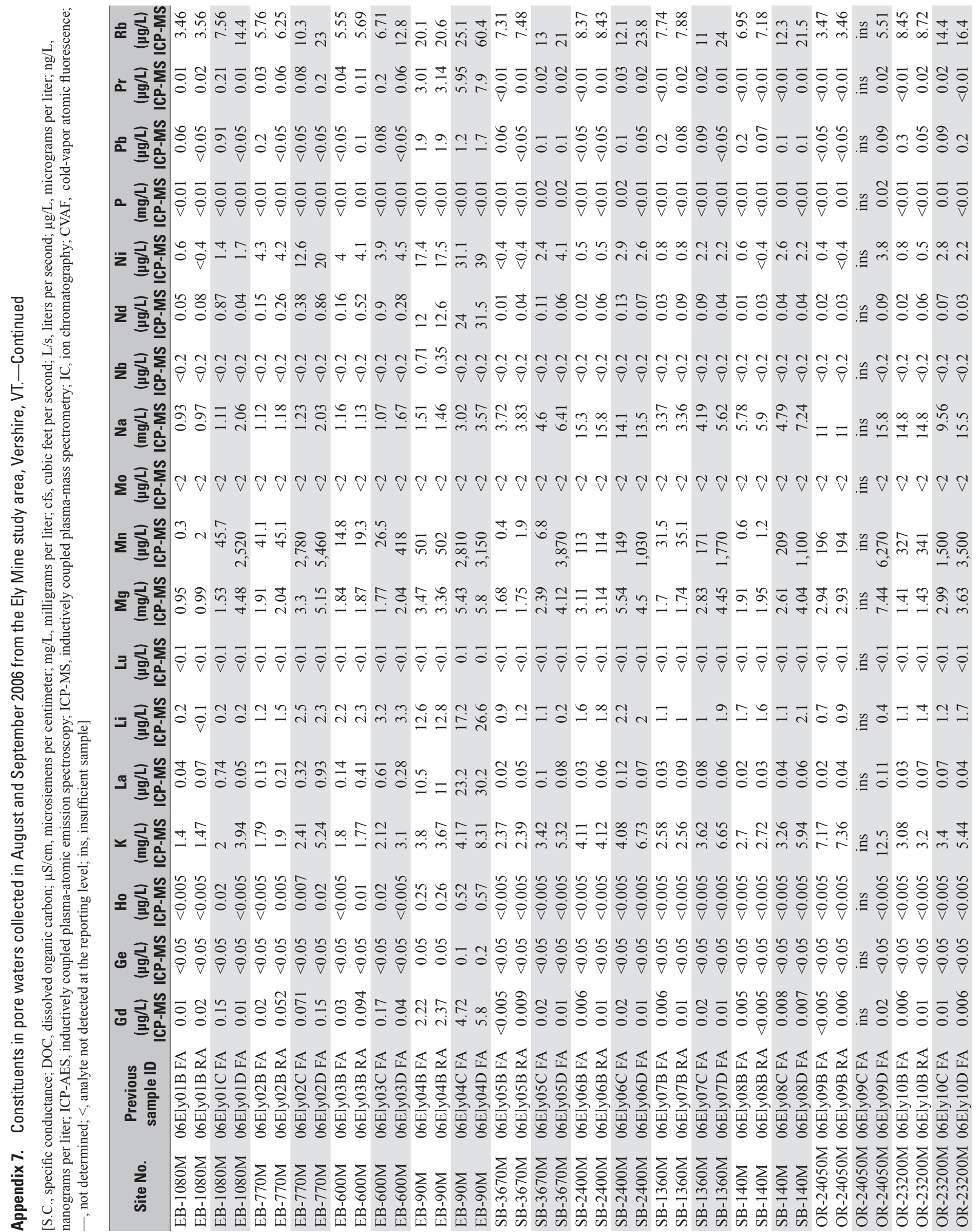




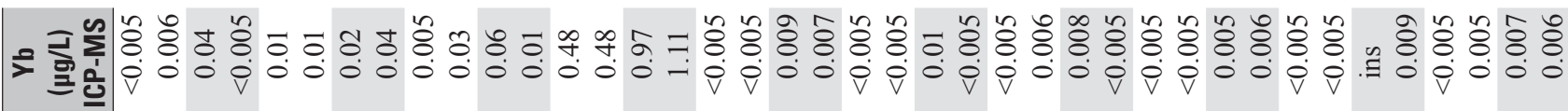

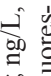

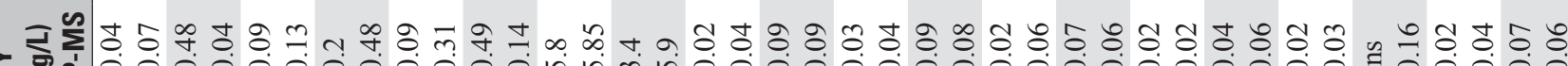

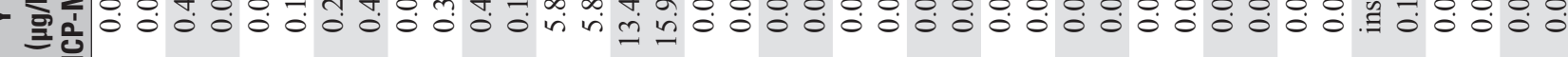

容

蒿

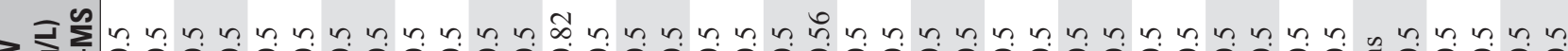

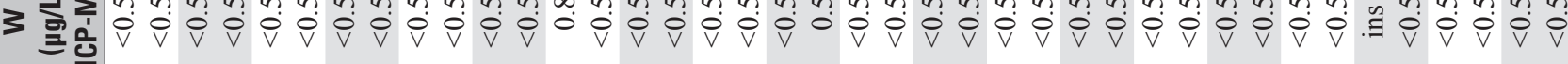

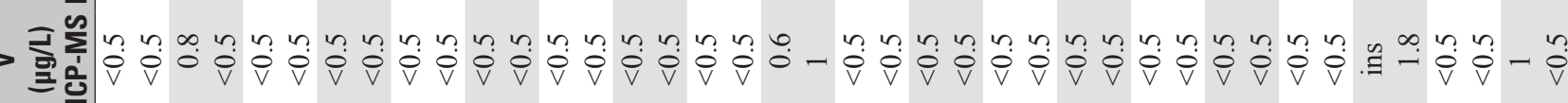

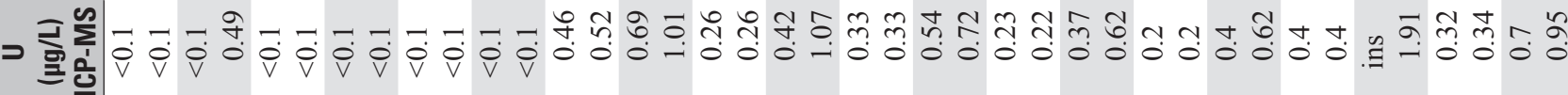

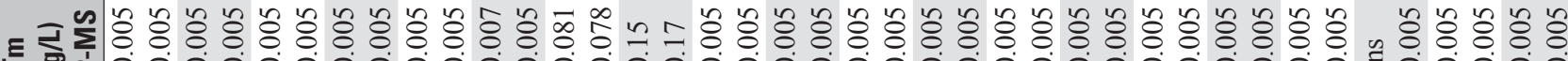

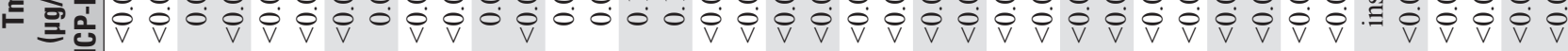

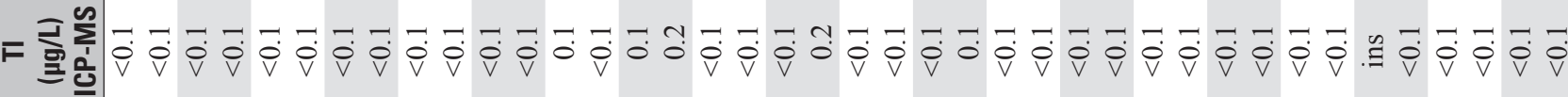

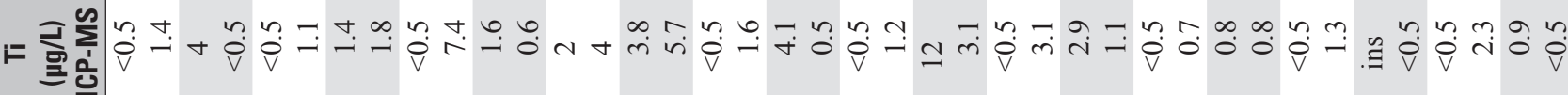

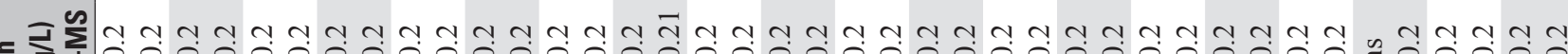

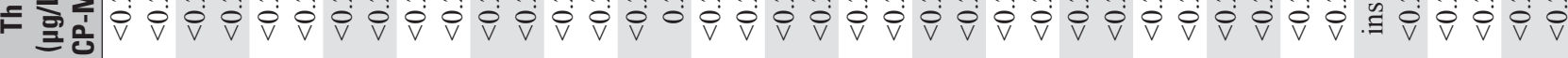

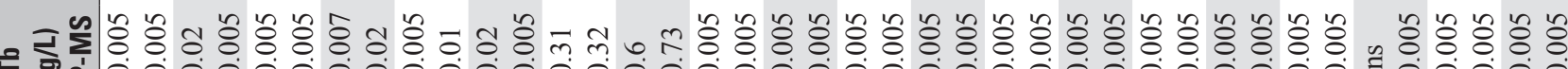

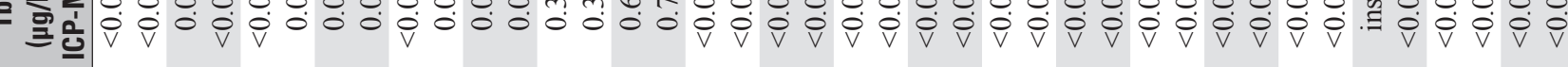

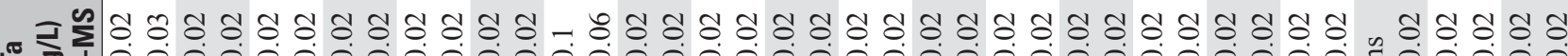

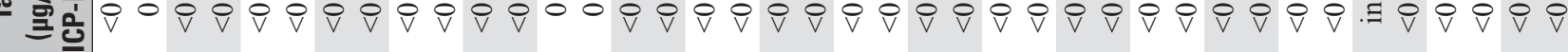

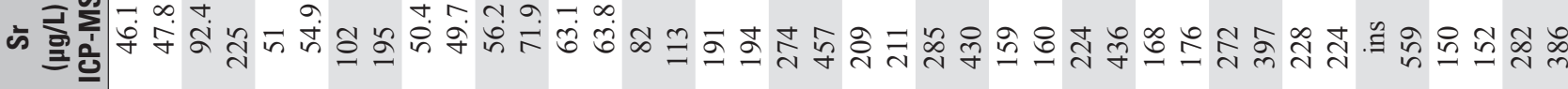

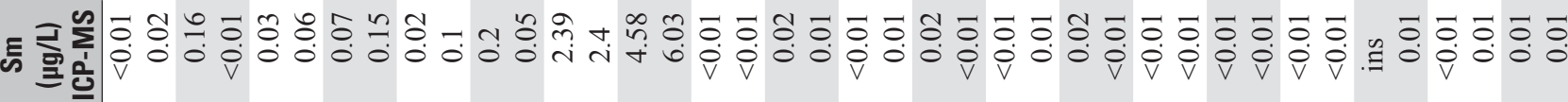
. .

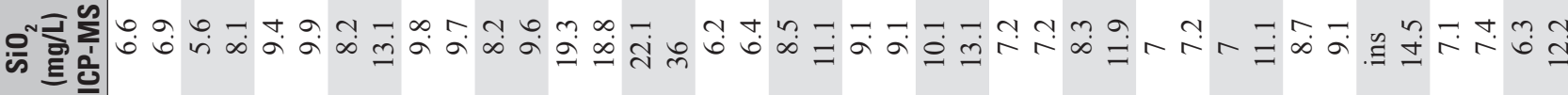

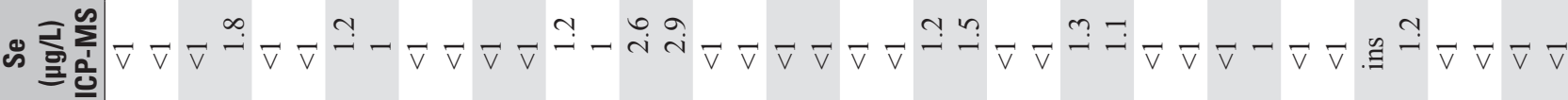

牙

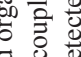

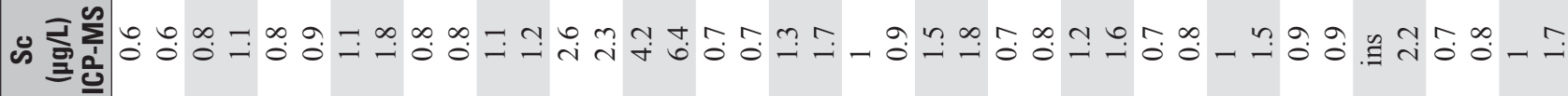

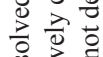

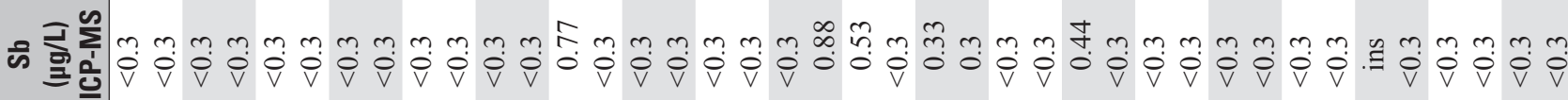
ช.

os

워

胥

总离

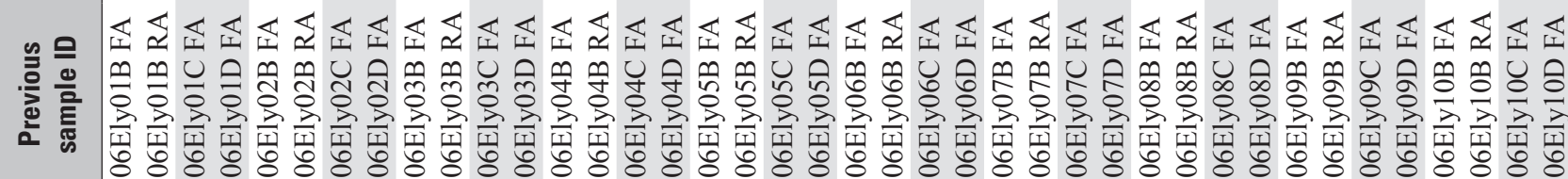
范 


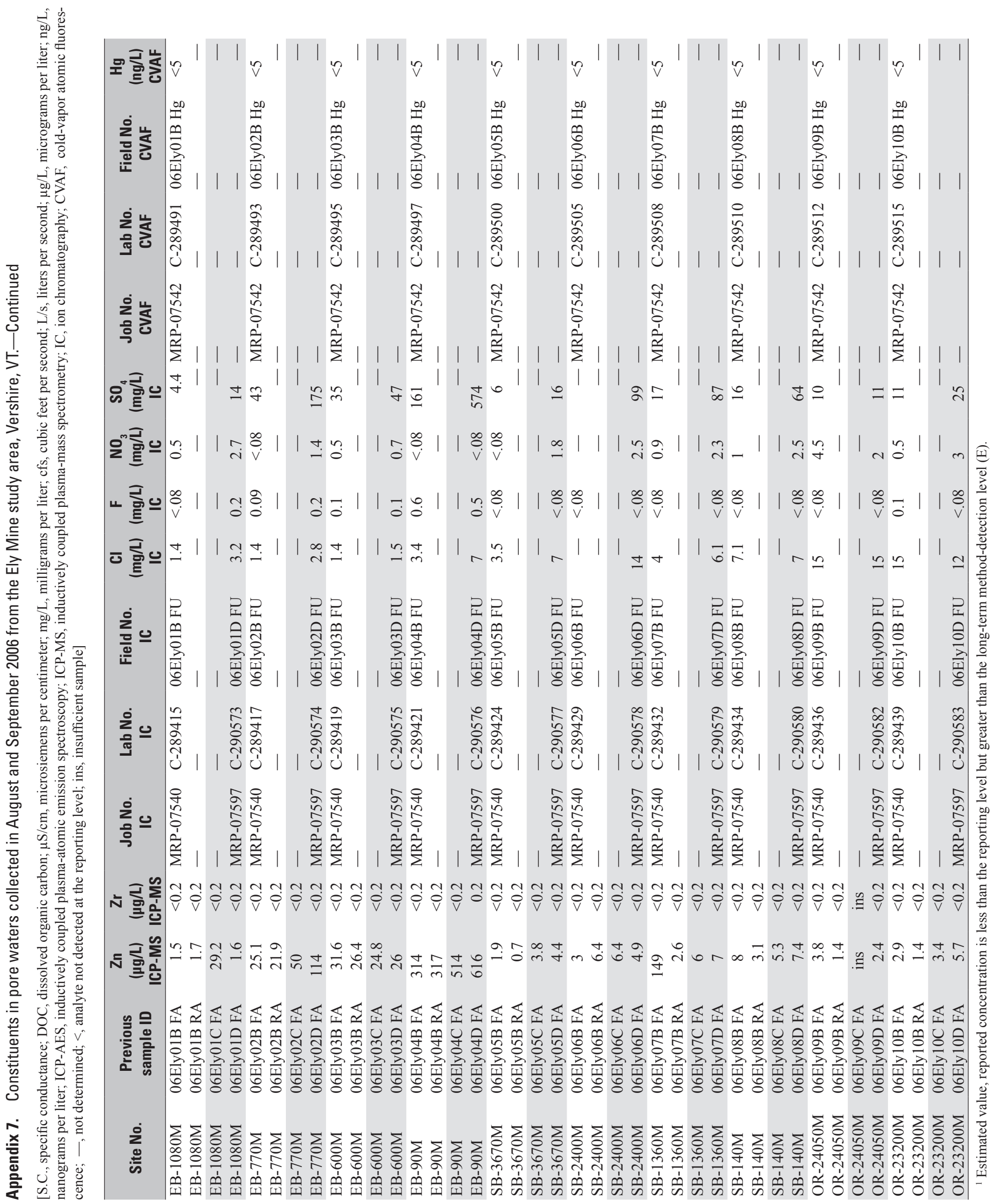





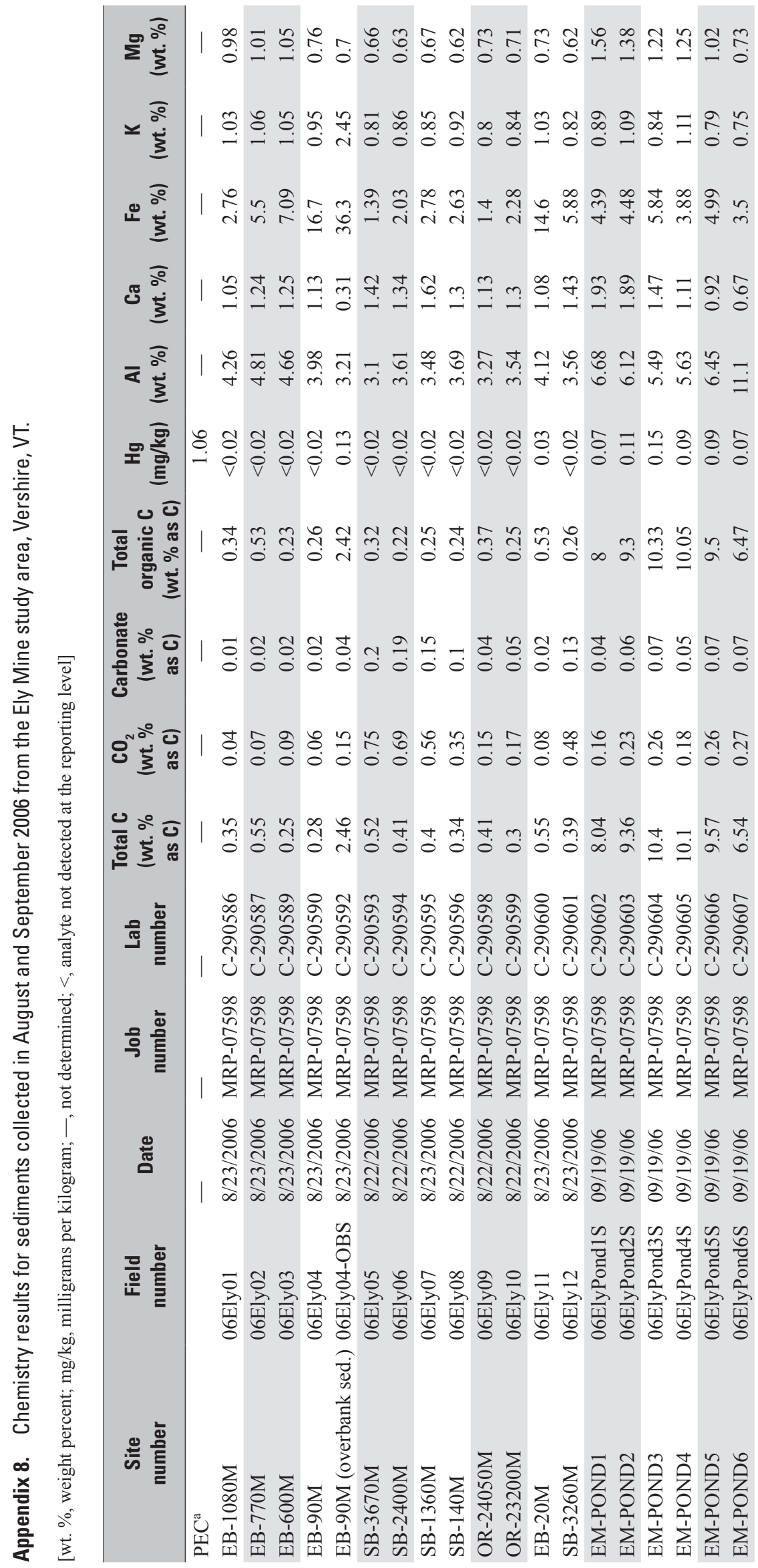




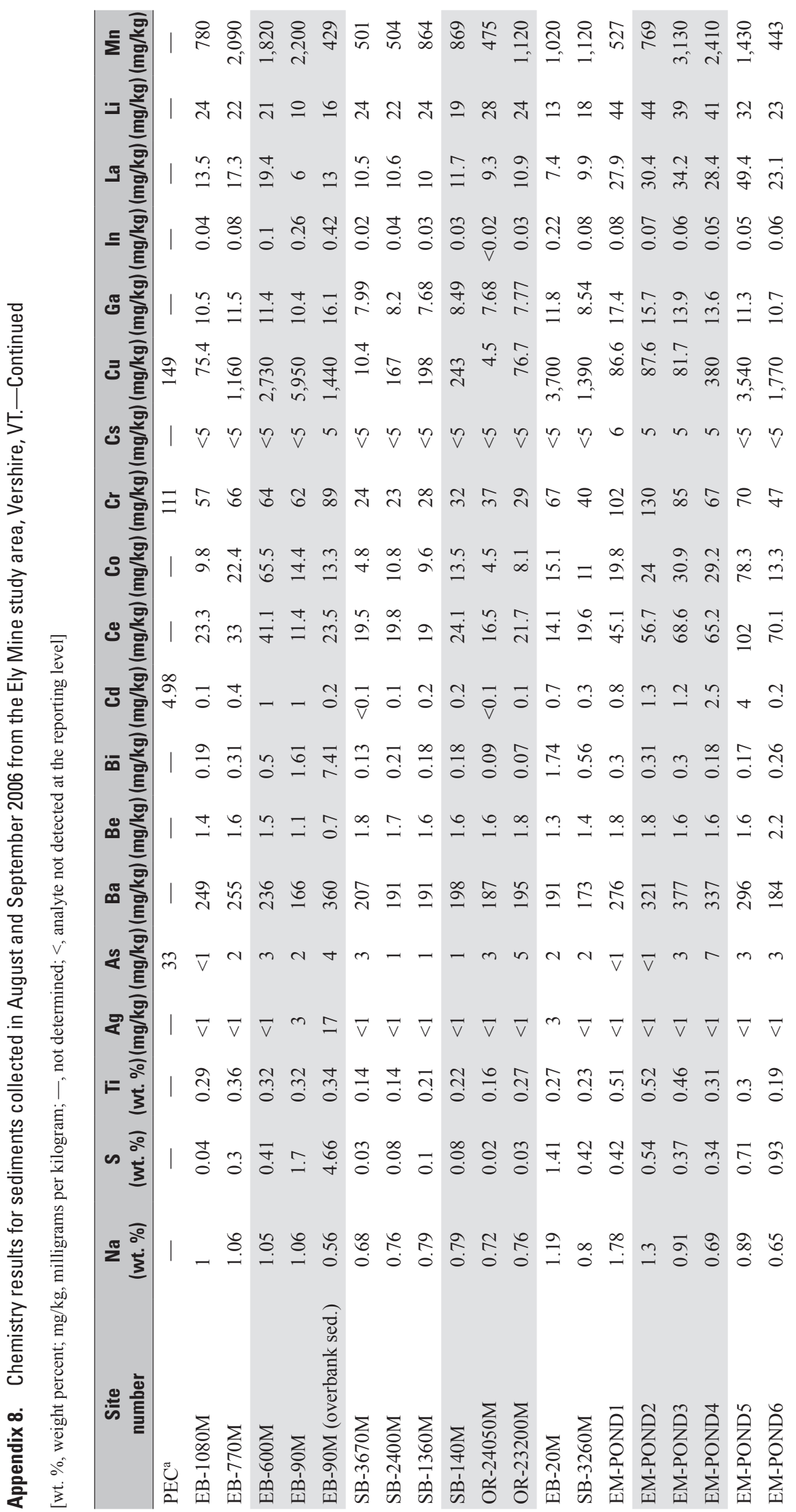




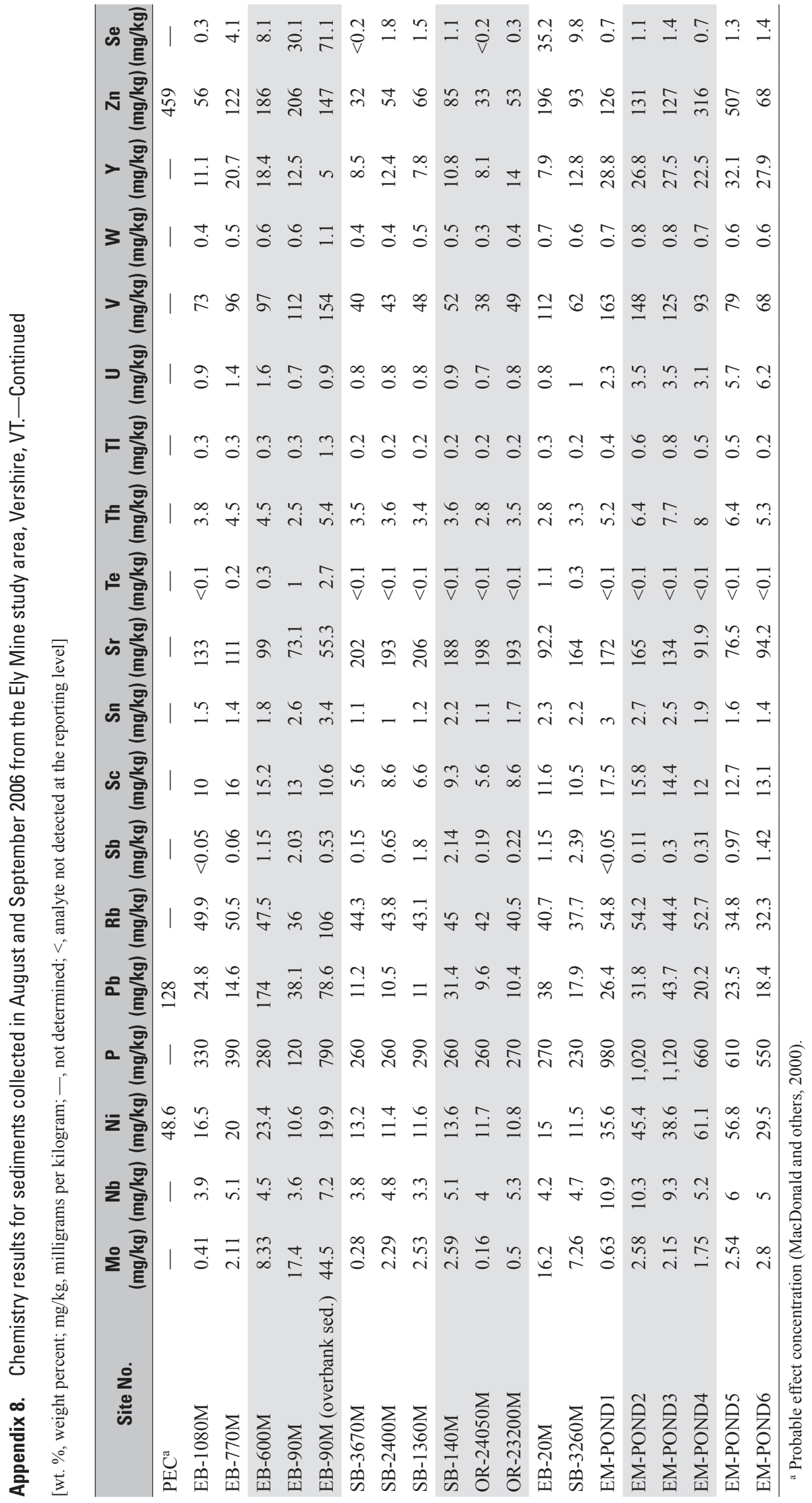




\section{Prepared by:}

USGS Publishing Network

Raleigh Publishing Service Center

3916 Sunset Ridge Road

Raleigh, NC 27607

For additional information regarding this publication, contact:

Robert R. Seal, II

U.S. Geological Survey

954 National Center

Reston, VA 20192

email: rseal@usgs.gov

Or visit the USGS New Hampshire and Vermont Water Science Center Web site at: http://vt.water.usgs.gov/ 



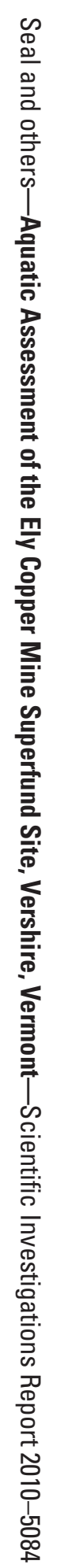

